\title{
Ensino técnico de design gráfico na cidade de São Paulo
}

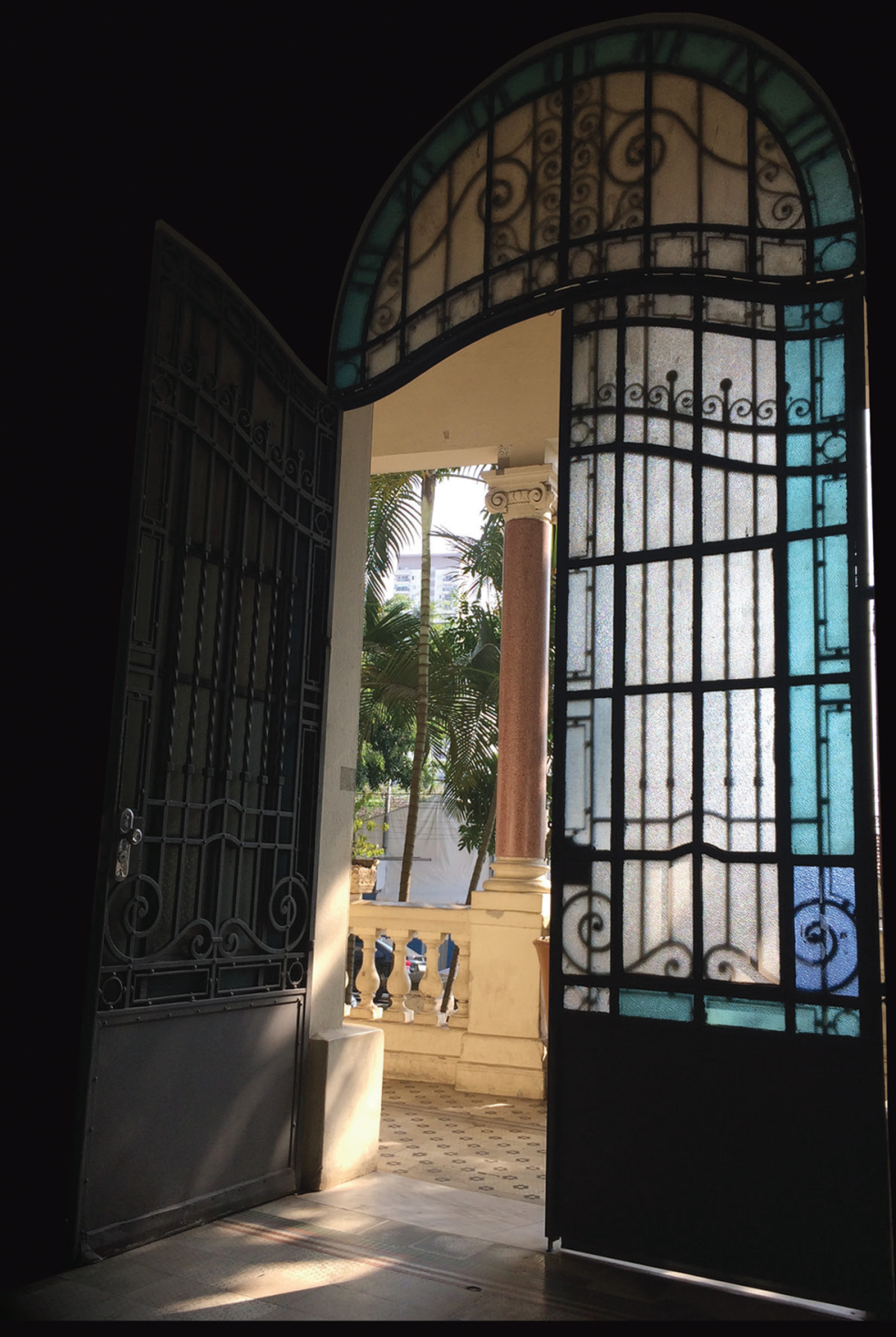

Maria Beatriz Saraiva Dinelli

Programa de Pós-Graduação em Design

Faculdade de Arquitetura e Urbanismo

Universidade de São Paulo

São Paulo, 2020 


\section{Ensino técnico de design gráfico na cidade de São Paulo}

Maria Beatriz Saraiva Dinelli

Dissertação apresentada à Faculdade de Arquitetura e Urbanismo da Universidade de São Paulo para obtenção do título de Mestra

Área de concentração: Design

Orientador: Prof. Dr. Luís Cláudio Portugal do Nascimento 
Autorizo a reprodução e divulgação total ou parcial deste trabalho, por qualquer meio convencional ou eletrônico, para fins de estudo e pesquisa, desde que citada a fonte.

Catalogação na Publicação

Serviço Técnico de Biblioteca

Faculdade de Arquitetura e Urbanismo da Universidade de São Paulo

Dinelli, Maria Beatriz Saraiva

Ensino técnico de design gráfico na cidade de São Paulo /

Maria Beatriz Saraiva Dinelli; orientador Luís Cláudio

Portugal do Nascimento. - São Paulo, 2020.

$304 \mathrm{p}$.

Dissertação (Mestrado) - Faculdade de Arquitetura e Urbanismo da Universidade de São Paulo.

Área de Concentração: Design.

1. Design Gráfico. 2. Comunicação Visual. 3. Pedagogia.

4. Ensino Profissional e Técnico (São Paulo).

I. Nascimento, Luís Cláudio Portugal do, orient. II. Título. 
A Giovanni, Alice, Geraldo e Fábio,

por acreditarem que tudo é possível.

Este trabalho também é dedicado a centenas de professores que estão, anonimamente, fazendo um trabalho heroico, generoso, tornando possível a existência do ensino técnico de comunicação visual em São Paulo. 


\section{Agradecimentos}

Ao Prof. Dr. Luís Claudio Portugal do Nascimento, orientador, amigo, incansável em suas observações pontuais, que me conduziu muito generosamente nesta jornada com paciência e clareza.

A todos os professores que contribuíram para realização deste estudo, com especial atenção à Profa. Dra Cyntia Santos Malaguti Sousa, participante de minha banca de qualificação, ao Prof. Dr. Marcelo José Oliveira de Farias, integrante da banca de qualificação e também de defesa, ao lado do Prof. Dr. Auresnede Pires Stephan. Seus apontamentos enriqueceram sobremaneira o trabalho.

Aos funcionários das secretarias e bibliotecas da pós-graduação e da graduação pela constante disponibilidade.

Aos amigos da pós-graduação, com quem tive prazer em dividir momentos de alegria, turbulência e tudo mais que a pós-graduação desperta, dentre eles: Ana Paula Coelho Carvalho, Caio Dutra, Célia Arbore, Cristina Dias, Cristine Brondani, Diego Ricca, Eduardo Ferreira, Eliane Corrêa, Fabio Mariano, Fernanda Tozzo, Frieda Nossack, Gabriella Araújo, Giancarlo Latorraca, Hugo Duran, Jaldomir da Silva Filho, Márcia Machado, Maria do Rosário Mira, Patrícia Lobo, Paulo Moretto, Rafael Toledo, Rogério Wittmann, Sérgio Kamimura e Tadeu Costa.

À Marta Zanatta, que revisou a presente dissertação.

Estendo meus agradecimentos às escolas, coordenadores, professores, alunos e ex-alunos que me acolheram, compartilhando suas percepções e experiências a respeito do ensino técnico de design gráfico. 


\section{Resumo}

Este estudo de reconhecimento se propôs a registrar o panorama do ensino de design gráfico (ou comunicação visual) no âmbito de escolas técnicas em atividade na cidade de São Paulo, em 2018 e 2019. Entre os aspectos observados, incluíram-se o universo de seus alunos, o perfil de professores, estruturas materiais e físicas disponíveis, conteúdos e processos pedagógicos, elementos de metodologia de projeto de design exercitados com os alunos, linguagens visuais presentes em resultados de trabalhos de alunos, além de questões ainda mais gerais intrínsecas à própria natureza do ensino técnico de design na realidade profissional e acadêmica brasileira. Os trabalhos de campo foram baseados, sobretudo, em duas das dez escolas técnicas de design gráfico em funcionamento na cidade de São Paulo (em uma escola da rede estadual de Escolas Técnicas de São Paulo, as Etecs, e em um curso do Senac-SP). Eles se desenvolveram por meio de entrevistas semiestruturadas com alunos, professores e coordenadores de cursos técnicos de design gráficos, bem como com ex-alunos. Valeram-se, também, de observações diretas de aulas e análises gráficas e semióticas da linguagem visual de pranchas de trabalhos executados por alunos, por ocasião da pesquisa. Alguns resultados sugerem, entre outros achados percebidos como relevantes, ocorrência de proximidade conceitual, metodológica e estética que teria sido identificada entre, de um lado, temáticas, orientações e propostas pedagógicas trabalhadas com os alunos e, de outro, o universo das artes plásticas e o da propaganda, nem sempre revelando, portanto, correspondência com o universo mais específico do design. Outro aspecto especialmente notável que emergiu na pesquisa teria sido o empenho pessoal de expressiva parcela do corpo docente atuante no ensino técnico de design gráfico, no sentido de buscar, com perceptível sinceridade, idealismo e comprometimento, propiciar a seus alunos formação técnica transformadora que lhes possa abrir horizontes, como forma de ampliar suas possibilidades de realização vocacional e pessoal.

Palavras-chave: pedagogia de design para jovens; ensino técnico de design; ensino de design gráfico; ensino técnico em São Paulo. 


\section{Abstract}

This recognition study aimed to register a panorama of teaching graphic design (or visual communication) within the scope of technical schools in the city of São Paulo in 2018 and 2019. Among the aspects observed, the students' universe, instructors' profiles, available material and physical structures, content and pedagogical processes, elements of design project methodology used with students, and visual languages present in student work were included, in addition to even more general issues intrinsic to the very nature of technical design education in the Brazilian professional and academic reality. The fieldwork was based mainly on two of the ten technical schools of graphic design in the city of São Paulo (in a school in the state network of Technical Schools in São Paulo, the Etecs, and in a course at Senac-SP). It was carried out through semi-structured interviews with students, instructors and coordinators of technical courses in graphic design, as well as with alumni. It also used direct observations of classes and graphic and semiotic analyses of the visual language of worksheets done by students during the research. Some results suggest, among other findings perceived as relevant, the occurrence of conceptual, methodological and aesthetic proximity identified among, on the one hand, themes, orientations and pedagogical proposals done with students and, on the other, the universe of fine arts and advertising, therefore not always showing correspondence with the more specific universe of design. Another particularly noteworthy aspect that emerged in the research was the personal commitment of a significant portion of the teaching staff working in the technical teaching of graphic design, in order to seek, with perceptible sincerity, idealism and commitment, to provide their students with transformative technical training that can open horizons, as a way to expand their possibilities of vocational and personal fulfillment.

Keywords: design pedagogy for young adults; design technical education; graphic design pedagogy; technical education in São Paulo. 


\section{5}

\section{Lista de figuras}

Figura 1: fachada Etec Carlos de Campos 135

Figura 2: mobília para expor trabalhos de alunos 136

Figura 3: suporte para expor trabalhos de alunos 136

$\begin{array}{ll}\text { Figura 4: } & \text { quadra poliesportiva }\end{array}$

$\begin{array}{ll}\text { Figura 5: } & \text { espaço de convivência e cantina }\end{array}$

Figura 6: $\quad$ oficina multiuso 138

Figura 7: oficina multiuso 138

$\begin{array}{lll}\text { Figura 8: } & \text { biblioteca } & 138\end{array}$

Figura 9: livros relacionados às artes plásticas e ao design 138

Figura 10: ateliê de desenho e pintura 140

Figura 11: $\quad$ estúdio de fotografia 141

Figura 12: $\quad$ estúdio de fotografia 141

Figura 13: fachada Senac Largo Treze 145

$\begin{array}{ll}\text { Figura 14: } & 146\end{array}$

Figura 15: livros de design e de áreas afins 146

Figura 16: área de convivência interna 146

$\begin{array}{ll}\text { Figura 17: } & 146\end{array}$

Figura 18: área de convivência externa 146

Figura 19: sala de aula adaptada com pranchetas 146

Figura 20: laboratório de "Macs" 148

Figura 21: laboratório de "PCs" 148

Figura 22: laboratório de informática com computadores "PC" 152

Figura 23: mockup representando sanduíches 180

$\begin{array}{ll}\text { Figura 24: } & \text { projeto de cartas de baralho }\end{array}$

Figura 25: $\quad$ logotipos, símbolos gráficos (massa de modelar) 184

Figura 26: projetos de cartaz em geometria irregular 251

Figura 27: projetos de cartaz em geometria regular 252

Figura 28: projeto de identidade visual 253

Figura 29: projeto de identidade visual 254

Figura 30: projeto de identidade visual 254 
Figura 31: $\quad$ projeto de identidade visual 254

Figura 32: desenvolvimento de mascote 255

Figura 33: desenvolvimento de mascote 255

Figura 34: exercícios de observação com técnica de aquarela 256

Figura 35: exercícios de observação com técnica de aquarela 256

Figura 36: projeto gráfico de revista (capa e folha dupla interna) 257

Figura 37: projeto gráfico de revista (capa e folha dupla interna) 258

Figura 38: $\quad$ projeto gráfico de revista (capa e folha dupla interna) 258

Figura 39: $\quad$ projeto de cartaz 259

Figura 40: $\quad$ projeto de cartaz 259

Figura 41: $\quad$ projeto de cartaz 260

Figura 42: $\quad$ projeto de cartaz "All Type" 260

Figura 43: $\quad$ projeto gráfico de baralho 260

0.6

\section{Lista de diagramas}

Diagrama 1: diagrama das coordenadas de localização conceitual da pesquisa (pranchas de 1 a 4 )

\section{7}

\section{Lista de mapas}

Mapa 1: distribuição geográfica das escolas técnicas com cursos de design gráfico (ou comunicação visual) na cidade de São Paulo, em 2019 


\section{8}

\section{Lista de quadros}

Quadro 1: quadro sinótico da estrutura metodológica da pesquisa

Quadro 2: $\quad$ quadro sinótico da estrutura da dissertação

Quadro 3: $\quad$ cronograma geral do mestrado e da pesquisa

\section{9}

\section{Lista de abreviaturas}
cap. capítulo
Mac.: abreviatura de computador Macintosh
p.: $\quad$ abreviatura de página

\subsection{0}

\section{Lista de siglas}

ABNT: $\quad$ Associação Brasileira de Normas e Técnicas

Aiba: Academia Imperial de Belas Artes

AIDG: $\quad$ Aplicativos Informatizados em Design Gráfico

AIDGD: $\quad$ Aplicativos Informatizados em Design Gráfico e Digital

CCBB: Centro Cultural Banco do Brasil

CNE: $\quad$ Conselho Nacional da Educação

Criv: $\quad$ Concepção e Representação da Identidade Visual

CV: Comunicação Visual

Etim: $\quad$ Ensino Técnico Integrado ao Médio

Esdi: $\quad$ Escola Superior de Desenho Industrial

Etec: Escolas Técnicas Estaduais

FAU: $\quad$ Faculdade de Arquitetura e Urbanismo

FCEP: Formas Compositivas de Elementos Plásticos

FEB: $\quad$ Formas Expressivas Bidimensionais 


$\begin{array}{ll}\text { Fuma: } & \text { Fundação Mineira de Arte } \\ \text { IAC: } & \text { Instituto de Arte Contemporânea } \\ \text { ladê: } & \text { Instituto de Arte de Decoração } \\ \text { IV: } & \text { Identidade Visual } \\ \text { Lao-rj: } & \text { Liceu de Artes e Ofícios do Rio de Janeiro } \\ \text { LTT: } & \text { Linguagem, Trabalho e Tecnologia } \\ \text { Masp: } & \text { Museu de Arte de São Paulo } \\ \text { MEC: } & \text { Ministério da Educação e Cultura } \\ \text { PC: } & \text { Personal Computer (computador pessoal) } \\ \text { PDF: } & \text { Portable Document Format (Formato Portátil de Documento) } \\ \text { PI: } & \text { Projeto Integrador } \\ \text { PTrid: } & \text { Projeto Tridimensional } \\ \text { QPT: } & \text { Qualificação Profissional Técnica } \\ \text { Senac: } & \text { Serviço Nacional de Aprendizagem Comercial } \\ \text { SP: } & \text { São Paulo } \\ \text { SPBA: } & \text { Sociedade Propagadora das Belas-Artes } \\ \text { TCC: } & \text { Trabalho de Conclusão de Curso } \\ \text { UC: } & \text { Unidade Curricular } \\ \text { Uemg: } & \text { Universidade do Estado de Minas Gerais } \\ \text { UMA: } & \text { Universidade Mineira de Arte } \\ \text { USP: } & \text { Universidade de São Paulo }\end{array}$


0

Elementos pré-textuais

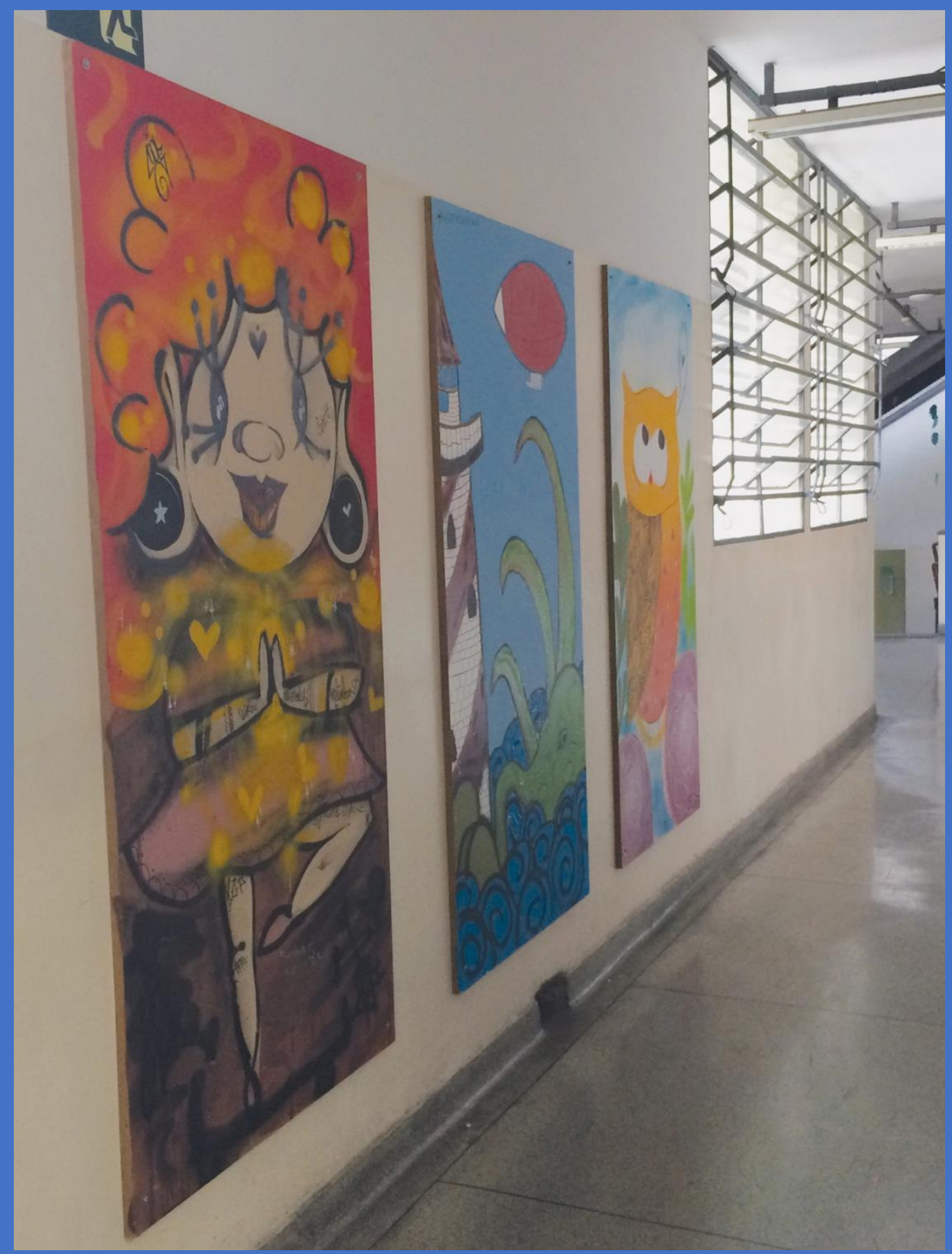




\section{Sumário}

Elementos pré-textuais

$0.1 \quad$ Dedicatória

$0.2 \quad$ Agradecimentos

0.3 Resumo

0.4 Abstract

$0.5 \quad$ Lista de figuras

$0.6 \quad$ Lista de diagramas

$0.7 \quad$ Lista de mapas

$0.8 \quad$ Lista de quadros

$0.9 \quad$ Lista de abreviaturas

$0.10 \quad$ Lista de siglas

$0.11 \quad$ Sumário

0.12 Apresentação das disposições internas deste volume

1 Caracterização geral da pesquisa 
2.0 Considerações gerais sobre a revisão da literatura correlata

$2.1 \quad$ Iniciativas pioneiras do ensino técnico de design na Europa Iniciativas pioneiras do ensino técnico de design no Brasil

3.0.2 Quadros sinóticos da estrutura metodológica da pesquisa e da estrutura da dissertação

3.0.2.1 Quadro sinótico da estrutura metodológica da pesquisa 60

3.0.2.2 Quadro sinótico da estrutura da dissertação 63

$\begin{array}{lll}3.0 .3 & \text { Questão fundamental } & 67\end{array}$

3.0.3.1 Questão fundamental (em seu enunciado sintético) 67

3.0.3.2 Questão fundamental (em seu enunciado completo) $\quad 67$

Aspectos metodológicos do subproblema 1 (universo dos alunos)

Dados necessários à resposta do subproblema 1

3.1.3 Técnicas adotadas na obtenção das informações do subproblema 1 
Aspectos metodológicos do subproblema 2 (perfil dos professores)

3.2.1 Dados necessários à resposta do subproblema 2

3.2.2 Fontes para aquisição dos dados do subproblema 2

3.2.3 Técnicas adotadas na obtenção das informações

do subproblema 2

Aspectos metodológicos do subproblema 3 (estruturas materiais e físicas)

Dados necessários à resposta do subproblema 3

3.3.3 Técnicas adotadas na obtenção das informações do subproblema 3

\section{Aspectos metodológicos do subproblema 4} (abordagens pedagógicas)

Técnicas adotadas na obtenção das informações do subproblema 4

\section{Aspectos metodológicos do subproblema 5} (elementos de metodologia de projeto exercitados)

3.5.3 Técnicas adotadas na obtenção das informações do subproblema 5 
Aspectos metodológicos do subproblema 6

(linguagens visuais de trabalhos de alunos)

3.6.1 Dados necessários à resposta do subproblema 6

3.6.2 Fontes para aquisição dos dados do subproblema 6

3.6.3 Técnicas adotadas na obtenção das informações

do subproblema 6

Técnicas de tratamento de dados do subproblema 6

Aspectos metodológicos do subproblema 7 (questões ainda mais gerais)

Dados necessários à resposta do subproblema 7

Técnicas adotadas na obtenção das informações do subproblema 7

\section{4}

4.0

4.1

\subsection{1}

4.1.1.1

4.1.1.2

4.1.2

4.1.2.1

\section{Resultados}

Considerações iniciais sobre os resultados

\section{6}

(universo dos alunos)

sobretudo, de professores

da rede Etec-SP

da rede Senac-SP

em comunicação visual e das escolas 
4.1.2.2 Perspectivas de respondentes associados a escolas $\begin{array}{ll}\text { da rede Senac-SP } & 98\end{array}$

4.1.3 Expectativas iniciais dos alunos em relação ao curso técnico 99

4.1.3.1 Perspectivas de respondentes associados a escolas da rede Etec-SP

4.1.3.2 Perspectivas de respondentes associados a escolas da rede Senac-SP

4.1.4 Habilidades consideradas relevantes na profissão do design gráfico

4.1.4.1 Perspectivas de respondentes associados a escolas da rede Etec-SP

4.1.4.2 Perspectivas de respondentes associados a escolas da rede Senac-SP

4.1.5 Percepções sobre a natureza do design gráfico (ou comunicação visual)

4.1.5.1 Perspectivas de respondentes associados a escolas da rede Etec-SP

4.1.5.2 Perspectivas de respondentes associados a escolas da rede Senac-SP

4.1.6 Percebida vocação pessoal para área da comunicação visual

4.1.6.1 Perspectivas de respondentes associados a escolas da rede Etec-SP

4.1.6.2 Perspectivas de respondentes associados a escolas da rede Senac-SP

4.1.7 Perspectivas profissionais futuras de alunos cursando o ensino técnico

4.1.7.1 Perspectivas de respondentes associados a escolas da rede Etec-SP

4.1.7.2 Perspectivas de respondentes associados a escolas da rede Senac-SP

4.1.8 Percebidas diferenças relatadas por egressos de cursos técnico: de comunicação visual em São Paulo quanto ao desempenho, em cursos universitários de design ou campos afins, de alunos que, como eles, hajam cursado o ensino técnico em comunicação visual em relação a seus colegas de turma 
4.1.8.1 Perspectivas de respondentes associados a escolas da rede Etec-SP

4.1.8.2 Perspectivas de respondentes associados a escolas da rede Senac-SP

Resultados concernentes ao subproblema 2 (perfil dos professores)

4.2.1 Formação individual dos professores

4.2.1.1 Perspectivas de respondentes associados a escolas da rede Etec-SP

4.2.1.2 Perspectivas de respondentes associados a escolas da rede Senac-SP

Perfil dos professores em relação às disciplinas lecionadas

4.2.2.1 Perspectivas de respondentes associados a escolas da rede Etec-SP

4.2.2.2 Perspectivas de respondentes associados a escolas da rede Senac-SP

4.2.3 Envolvimento dos professores com o design

4.2.3.1 Perspectivas de respondentes associados a escolas da rede Etec-SP

4.2.3.2 Perspectivas de respondentes associados a escolas da rede Senac-SP

Resultados concernentes ao subproblema 3 (estruturas materiais e físicas)

4.3.1 Aspectos mais gerais das estruturas materiais e físicas

4.3.1.1 Perspectivas de respondentes associados a escolas da rede Etec-SP

4.3.1.2 Perspectivas de respondentes associados a escolas da rede Senac-SP

4.3.2 Laboratório de informática, equipamentos e aplicativos gráficos disponíveis

4.3.2.1 Perspectivas de respondentes associados a escolas da rede Etec-SP

4.3.2.2 Perspectivas de respondentes associados a escolas da rede Senac-SP 
4.4 Resultados concernentes ao subproblema 4 (abordagens pedagógicas)

153

4.4.1 Estrutura curricular geral dos programas

de escolas técnicas selecionadas

153

4.4.1.1 Estrutura curricular geral dos programas de escolas técnicas selecionadas não vinculadas ao ensino médio

4.4.1.1.1 Perspectivas de respondentes associados a escolas da rede Etec-SP

4.4.1.1.2 Perspectivas de respondentes associados a escolas da rede Senac-SP

4.4.1.2 Estrutura curricular de programas de escolas técnicas integradas ao ensino médio (Etim)

4.4.1.2.1 Perspectivas de respondentes associados a escolas da rede Etec-SP

4.4.2 Aspectos didático-metodológicos 161

4.4.2.1 Perspectivas de respondentes associados a escolas da rede Etec-SP

4.4.2.2 Perspectivas de respondentes associados a escolas da rede Senac-SP

4.4.3 Conteúdos, abordagens, propostas e atividades desenvolvidas

4.4.3.1 Conteúdos, abordagens, propostas e atividades desenvolvidas na pedagogia das escolas da rede Etec-SP 166

4.4.3.1.1 Conteúdos de história da arte 167

4.4.3.1.2 Instrução de aplicativos gráficos 169

4.4.3.1.3 Noções de desenho geométrico 170

4.4.3.1.4 Introdução a elementos de tipografia 171

4.4.3.1.5 Elementos de teorias da cor 173

$\begin{array}{lll}\text { 4.4.3.1.6 Introdução à fotografia } & 174\end{array}$

4.4.3.1.7 Elementos de composição visual 176

4.4.3.1.8 Projetos de programas de identidade visual 177

$\begin{array}{lll}\text { 4.4.3.1.9 Noções de marketing } & 178\end{array}$

4.4.3.1.10 Produção manual de modelos físicos de representação tridimensional 179

4.4.3.1.11 Noções de animação digital e de construção de sites 179

$\begin{array}{lll}\text { 4.4.3.1.12 Visitas técnicas } & 181\end{array}$ 
4.4.3.2 Conteúdos, abordagens, propostas e atividades desenvolvidas na pedagogia das escolas da rede Senac-SP $\quad 182$

4.4.4 Grau de motivação verbalizado por alunos e ex-alunos em relação às atividades pedagógicas

4.4.4.1 Grau de motivação verbalizado por alunos e ex-alunos de escolas da rede Etec em relação às atividades pedagógicas

4.4.4.1.1 Experiências pedagógicas percebidas como mais especialmente positivas por alunos e ex-alunos de escolas da rede Etec-SP

4.4.4.1.2 Experiências pedagógicas percebidas como menos especialmente positivas por alunos e ex-alunos de escolas da rede Etec-SP

4.4.4.2 Grau de motivação verbalizado por alunos e ex-alunos de escolas da rede Senac em relação às atividades pedagógicas 190

4.4.4.2.1 Experiências pedagógicas percebidas como mais especialmente positivas por alunos e ex-alunos de escolas da rede Senac-SP

4.4.4.2.2 Experiências pedagógicas percebidas como menos especialmente positivas por alunos e ex-alunos de escolas da rede Senac-SP

4.4.5 Percepções comparativas dos alunos sobre práticas de trabalhos individuais e em grupo

4.4.5.1 Perspectivas de respondentes associados a escolas da rede Etec-SP

4.4.5.2 Perspectivas de respondentes associados a escolas da rede Senac-SP

4.4.6 Filosofias pedagógicas eventualmente fundamentadoras de práticas de ensino adotadas

4.4.6.1 Perspectivas de respondentes associados a escolas da rede Etec-SP

4.4.6.2 Perspectivas de respondentes associados a escolas da rede Senac-SP

4.4.7 Percebido alinhamento entre conteúdos trabalhados e objetivos da formação, segundo visão de discentes 
4.4.7.1 Perspectivas de respondentes associados a escolas da rede Etec-SP

4.4.7.2 Perspectivas de respondentes associados a escolas da rede Senac-SP

4.4.8 Eficiência didática dos professores, segundo percepção de alunos e ex-alunos

4.4.8.1 Perspectivas de respondentes associados a escolas da rede Etec-SP

4.4.8.2 Perspectivas de respondentes associados a escolas da rede Senac-SP

4.4.9 Percebida eficiência pedagógica da formação

4.4.9.1 Perspectivas de respondentes associados a escolas da rede Etec-SP

4.4.9.2 Perspectivas de respondentes associados a escolas da rede Senac-SP

4.4.10 Visão dos professores quanto ao curso técnico em que atuam

4.4.10.1 Perspectivas de respondentes associados a escolas da rede Etec-SP

4.4.10.2 Perspectivas de respondentes associados a escolas da rede Senac-SP

4.4.11 Processos de avaliação de desempenho dos alunos

4.4.11.1 Perspectivas de respondentes associados a escolas da rede Etec-SP

4.4.11.2 Perspectivas de respondentes associados a escolas da rede Senac-SP

4.4.12 Percebidas necessidades de adequação de conteúdos segundo ex-alunos

4.4.12.1 Perspectivas de respondentes associados a escolas da rede Etec-SP

4.4.12.2 Perspectivas de respondentes associados a escolas da rede Senac-SP

4.4.13 Processos de definição das temáticas das propostas dos exercícios de projeto

4.4.13.1 Perspectivas de respondentes associados a escolas da rede Etec-SP 
4.4.13.2 Perspectivas de respondentes associados a escolas da rede Senac-SP

4.4.14 Percebida relação de proporcionalidade entre teoria e prática em atividades pedagógicas

4.4.14.1 Perspectivas de respondentes associados a escolas da rede Etec-SP

4.4.14.2 Perspectivas de respondentes associados a escolas da rede Senac-SP

4.4.15 Materiais didáticos de apoio

4.4.15.1 Perspectivas de respondentes associados a escolas da rede Etec-SP

4.4.15.2 Perspectivas de respondentes associados a escolas da rede Senac-SP

4.5 Resultados concernentes ao subproblema 5 (elementos de metodologia de projeto exercitados)

4.5.1 Estrutura metodológica básica de projeto exercitada com os alunos

4.5.1.1 Perspectivas de respondentes associados a escolas da rede Etec-SP

4.5.1.2 Perspectivas de respondentes associados a escolas da rede Senac-SP

4.5.2 Centralidade eventualmente conferida aos usuários dos projetos

4.5.2.1 Perspectivas de respondentes associados a escolas da rede Etec-SP

4.5.2.2 Perspectivas de respondentes associados a escolas da rede Senac-SP

4.6 Resultados concernentes ao subproblema 6 (linguagens visuais de trabalhos de alunos) 
4.7.1 Objetivos e ideários do ensino técnico de design gráfico

4.7.1.1 Objetivos e ideários do ensino técnico de design gráfico, com base em documentos institucionais públicos

4.7.1.1.1 Objetivos e ideários do ensino técnico de design gráfico com base no Plano de Curso da Etec-SP

4.7.1.1.2 Objetivos e ideários do ensino técnico de design gráfico com base no Plano de Curso da Senac-SP

4.7.1.2 Objetivos e ideários do ensino técnico de design gráfico, com base na visão de professores

4.7.1.2.1 Perspectivas de respondentes associados a escolas da rede Etec-SP

4.7.1.2.2 Perspectivas de respondentes associados a escolas da rede Senac-SP

Papel percebido do ensino técnico na atividade profissional do design

4.7.2.1 Perspectivas de respondentes associados a escolas da rede Etec-SP

4.7.2.2 Perspectivas de respondentes associados a escolas da rede Senac-SP

4.7.3 Relação entre ensino técnico e ensino superior de design gráfico e de áreas afins

4.7.3.1 Perspectivas de respondentes associados a escolas da rede Etec-SP

4.7.3.2 Perspectivas de respondentes associados a escolas da rede Senac-SP

4.7.4 Eventuais influências relatadas por egressos, na escolha posterior de cursos universitários

4.7.4.1 Perspectivas de respondentes associados a escolas da rede Etec-SP

4.7.4.2 Perspectivas de respondentes associados a escolas da rede Senac-SP

4.7.5 Antevisões de propostas pedagógicas 
4.7.6 Matizes político-ideológicos eventualmente identificáveis em práticas pedagógicas pesquisadas

4.7.6.1 Perspectivas de respondentes associados a escolas da rede Etec-SP

4.7.6.2 Perspectivas de respondentes associados a escolas da rede Senac-SP

Recapitulação de alguns principais resultados, conclusões e sugestões de pesquisas complementares 


\subsection{2}

\section{Apresentação das disposições internas deste volume}

O corpo deste trabalho é constituído por cinco capítulos, além do capítulo de referências. O capítulo 1, "Caracterização geral da pesquisa", apresenta a questão fundamental, que norteou toda a investigação, e os sete subproblemas dela derivados. Neste capítulo, situam-se, ainda, os objetivos geral e específicos, introdução ao estudo, definições de conceitos pertinentes ao entendimento do estudo, justificativa, pressuposições, delimitações e eticidade da pesquisa. Na sequência, o capítulo 2, "Quadro referencial teórico", oferece uma revisão bibliográfica básica, com o objetivo de situar o problema da pesquisa na literatura correlata do campo de conhecimento do design e do ensino técnico.

O capítulo 3, "Método de pesquisa", apresenta o modo como esta pesquisa foi estruturada, situando-a, primeiramente, por intermédio do "diagrama das coordenadas de localização conceitual da pesquisa", na grande área das ciências sociais aplicadas e no campo do design. A seguir, expõem-se dois quadros sinóticos que sintetizam a estrutura metodológica da pesquisa e a estrutura da dissertação. Nos quadros sinóticos, apresentam-se a questão fundamental e os sete subproblemas que dela se originam, especificando-se os dados para responder aos subproblemas, onde obtê-los, as técnicas de coleta e tratamento empregados, bem como as indagações exploratórias, que são os instrumentos utilizados para revolver os dados.

O capítulo 4, "Resultados", apresenta o relato de dados e análises correspondentes a cada subproblema, dispostos em secções. Cada subproblema buscou fazer um reconhecimento de determinado aspecto relevante da pedagogia do design gráfico no ensino técnico na cidade de São Paulo. O subproblema 1 se ocupou do universo de seus alunos; o subproblema 2 expôs o perfil de seus professores; o subproblema 3 apontou para as estruturas materiais e físicas disponíveis; o subproblema 4 dispôs questões relativas a abordagens pedagógicas praticadas; o subproblema 5 considerou elementos de metodologia de projeto de design exercitados com os alunos, o subproblema 6 abordou as linguagens visuais características 
de trabalhos de alunos e, por fim, o subproblema 7 se ocupou de questões ainda mais gerais intrínsecas à natureza do ensino técnico de design.

O capítulo 5, "Recapitulação de alguns principais resultados, conclusões e sugestões de pesquisas complementares", apresenta uma recapitulação do trabalho, sumariando alguns principais resultados expostos no capítulo 4 , bem como as conclusões obtidas por meio da sistematização e análise conjunta dos resultados independentes apresentados no capítulo anterior, visando apreender padrões de associação mais abstratos, e, ainda, as análises resultantes finais em grau ainda mais elevado de abstração. Na sequência, expõem-se sugestões de pesquisas complementares. Por fim, apresenta-se o capítulo 6, "Referências", com a relação de toda bibliografia, citada e complementar, utilizada nesta pesquisa, incluindo em suporte eletrônico. 
Caracterização geral da pesquisa

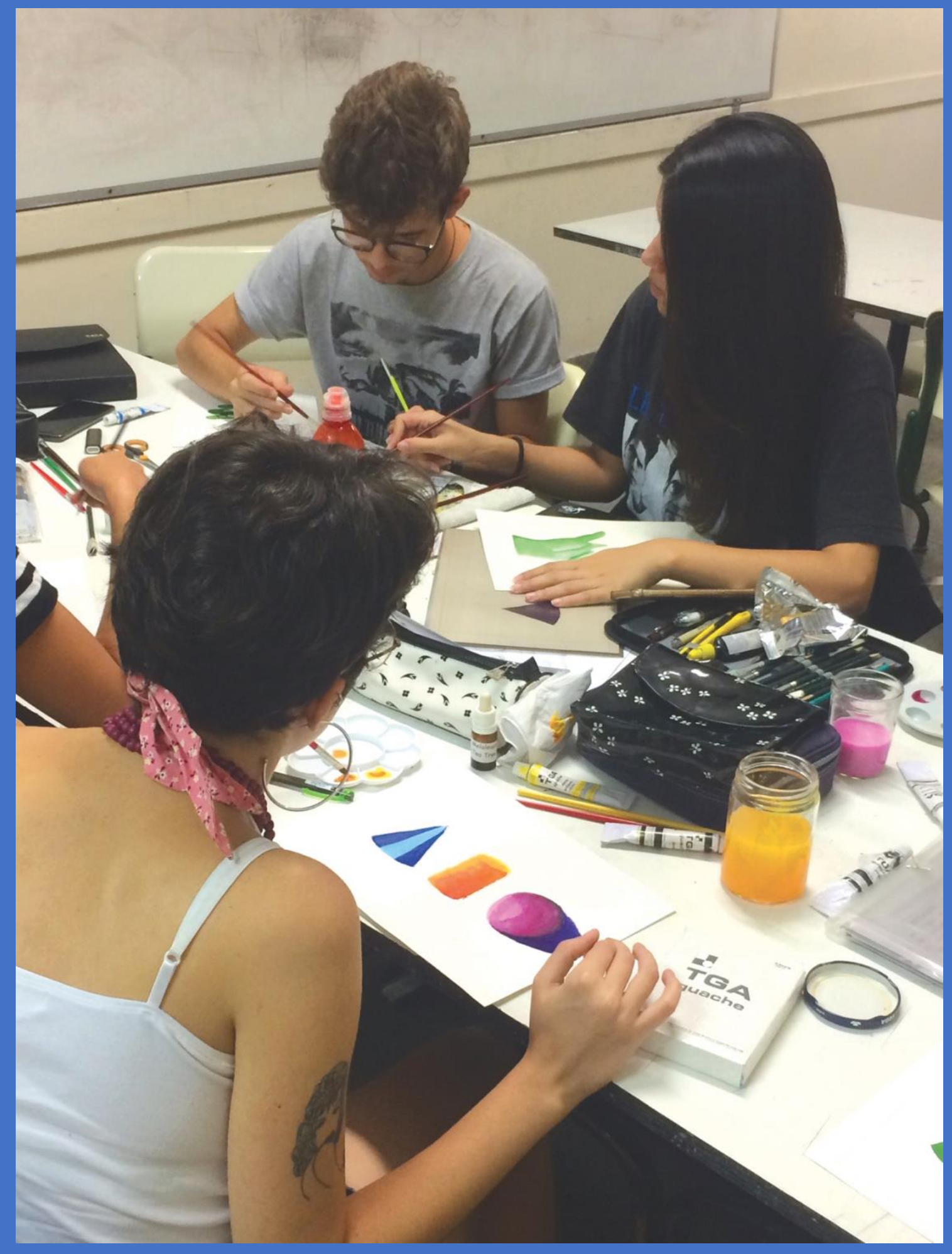




\section{Caracterização geral da pesquisa}

1.1

Objeto da pesquisa

Pedagogia do design gráfico no ensino técnico na cidade de São Paulo

\section{2}

\section{Questão fundamental}

Que aspectos relevantes podem ser identificados, por meio de estudo qualitativo de reconhecimento da realidade do ensino técnico de design gráfico na cidade de São Paulo, em 2018 e 2019, em termos do universo de seus alunos, do perfil de professores, de estruturas materiais e físicas disponíveis, de abordagens pedagógicas praticadas, de elementos de metodologia de projeto de design exercitados com os alunos, de linguagens visuais características de trabalhos de alunos e de questões ainda mais gerais intrínsecas à natureza do ensino técnico de design, com base em pesquisas de campo realizadas, sobretudo, em duas das dez escolas de ensino técnico de design gráfico em atividade na cidade de São Paulo? 


\section{3}

\section{Objetivos}

\subsection{1}

\section{Objetivo geral}

Identificar, por meio de estudo qualitativo de reconhecimento da realidade do ensino técnico de design gráfico na cidade de São Paulo, em 2018 e 2019, aspectos relevantes em termos do universo de seus alunos, do perfil de professores, de estruturas materiais e físicas disponíveis, de abordagens pedagógicas praticadas, de elementos de metodologia de projeto de design exercitados com os alunos, de linguagens visuais características de trabalhos de alunos e de questões ainda mais gerais intrínsecas à natureza do ensino técnico de design, com base em pesquisas de campo realizadas, sobretudo, em duas das dez escolas de ensino técnico de design gráfico em atividade na cidade de São Paulo.

\subsection{2}

\section{Objetivos específicos}

\subsubsection{1}

Identificar, por meio de estudo qualitativo de reconhecimento da realidade do ensino técnico de design gráfico na cidade de São Paulo, em 2018 e 2019, aspectos relevantes em termos do universo de seus alunos.

\subsubsection{2}

Identificar, por meio de estudo qualitativo de reconhecimento da realidade do ensino técnico de design gráfico na cidade de São Paulo, em 2018 e 2019, aspectos relevantes em termos do perfil de seus professores.

\subsubsection{3}

Identificar, por meio de estudo qualitativo de reconhecimento da realidade do ensino técnico de design gráfico na cidade de São Paulo, em 2018 e 2019, aspectos relevantes em termos de suas estruturas materiais e físicas disponíveis. 


\subsubsection{4}

Identificar, por meio de estudo qualitativo de reconhecimento da realidade do ensino técnico de design gráfico na cidade de São Paulo, em 2018 e 2019, aspectos relevantes em termos de abordagens pedagógicas praticadas.

\subsubsection{5}

Identificar, por meio de estudo qualitativo de reconhecimento da realidade do ensino técnico de design gráfico na cidade de São Paulo, em 2018 e 2019, aspectos relevantes em termos de elementos de metodologia de projeto de design exercitados com os alunos.

\subsubsection{6}

Identificar, por meio de estudo qualitativo de reconhecimento da realidade do ensino técnico de design gráfico na cidade de São Paulo, em 2018 e 2019, aspectos relevantes em termos de linguagens visuais características de trabalhos de alunos.

\subsubsection{7}

Identificar, por meio de estudo qualitativo de reconhecimento da realidade do ensino técnico de design gráfico na cidade de São Paulo, em 2018 e 2019, aspectos relevantes em termos de questões ainda mais gerais intrínsecas à natureza do ensino técnico de design. 


\section{4}

\section{Introdução ao estudo}

A temática do ensino de design no Brasil tem gerado debates e reflexões acerca de sua peculiaridade. A amplitude, complexidade e vigor do universo da pedagogia do design é manifestada, sobretudo, a partir da década de 1990, por meio da multiplicação da oferta de cursos, implicando variedade de conteúdos, abordagens e habilitações.

O design gráfico, como uma das subáreas de conhecimento do design, tem apresentado grande expansão de cursos ofertados. Dentro desse campo de conhecimento, os cursos técnicos de design gráfico, denominados "Técnico em Comunicação Visual", propõem desenvolver a capacidade de criação de uma variedade de projetos que demandam uma diversidade de competências e saberes, tais como: identidade visual de empresas, embalagens, anúncios para mídia impressa e digital, projetos editoriais de livro e revista etc. (MEC, 2000).

Pressupõe-se, nesta investigação, que a modalidade técnica de ensino possua especificidades próprias. Neste sentido, esta pesquisa se propôs a identificar, por meio de estudo qualitativo de reconhecimento, apoiado, sobretudo, em duas das dez escolas de ensino técnico de design gráfico em atividade, em 2018 e 2019, na cidade de São Paulo, aspectos relevantes em termos do universo de seus alunos, do perfil de professores, de estruturas materiais e físicas disponíveis, de abordagens pedagógicas praticadas, de elementos de metodologia de projeto de design exercitados com os alunos, de linguagens visuais características de trabalhos de alunos e de questões ainda mais gerais intrínsecas à natureza do ensino técnico de design.

Questões do universo de seus alunos abordaram, por exemplo, o perfil pessoal dos alunos; processos de escolha do curso; expectativas iniciais dos alunos em relação ao curso técnico; percepções sobre a natureza do design gráfico; perspectivas profissionais futuras de alunos cursando o ensino técnico etc. Aspectos do perfil de seus professores envolveram a formação individual dos professores, o perfil dos professores em relação às disciplinas lecionadas, bem como o envolvimento dos professores com o design. Questões relativas a estruturas materiais e físicas incluíram, por exemplo, os laboratórios, oficinas, biblioteca, bancadas, computadores, salas de aula e iluminação ambiente. Questões pedagógicas compreenderam 
a estrutura curricular geral dos programas; aspectos didático-metodológicos; conteúdos, abordagens, propostas e atividades desenvolvidas; filosofias pedagógicas eventualmente fundamentadoras de práticas de ensino; processos de avaliação de desempenho dos alunos; materiais didáticos de apoio, entre outras. Questões de metodologia de projeto de design trabalhadas com os alunos abrangeram a estrutura metodológica básica de projeto exercitada com os alunos, bem como a centralidade eventualmente conferida aos usuários nos exercícios de projeto.

Aspectos de linguagens visuais incorporaram questões relativas à organização, proporções, ritmo, modulação, padronizações, unidade e diversidade formal, além de sintaxe e semântica presentes nos exercícios desenvolvidos. Questões mais gerais da natureza do próprio ensino técnico de design englobaram, por exemplo, os objetivos e ideários do ensino técnico de design gráfico; o papel percebido do ensino técnico na atividade profissional do design; a relação entre ensino técnico e ensino superior de design gráfico com áreas afins; matizes político-ideológicos eventualmente identificáveis em práticas pedagógicas pesquisadas; eventuais influências relatadas por egressos na escolha posterior de cursos universitários etc.

Se, historicamente, cursos técnicos são vistos como formação menor, evidenciada pela estrutura do ensino brasileiro - de um lado, a formação propedêutica responsável pela formação geral e, de outro, a formação técnica profissional, correspondendo à formação específica (FERRETTI, 2006) -, a ênfase na prática é um diferencial do ensino técnico, que, por meio da utilização de laboratórios de ensino, possibilita aos estudantes maior interação com a teoria (SCACCHETTI, 2013).

O emprego do termo "ensino técnico" só se generalizou na Europa durante a década de 1870, sendo pouco utilizado no Brasil antes de 1880. Anteriormente, era conhecido por "ensino industrial", ou "ensino científico". A parte artística do ensino técnico era denominada "desenho técnico" ou "desenho industrial", englobando diferentes tipos de desenho aplicado a fins práticos, como, por exemplo, desenho geométrico, desenho mecânico, desenho de perspectiva e desenho de padrões e de ornamentos. Além disso, correspondia ao aprendizado prático de artes aplicadas, mecânicas ou decorativas em oficinas ou ateliês (CARDOSO, 2004).

Existem leis, pareceres e decretos institucionalizados no Brasil para regular e regulamentar a Educação Profissional Técnica de Nível Médio no país. 
A Lei n 9.394 (BRASIL, 1996) definiu as diretrizes e bases para a educação no Brasil, cujos valores como a estética da sensibilidade, a política da igualdade e a ética da identidade pautam a formação do trabalhador cidadão, sendo a base para a formação do currículo que, no paradigma anterior à lei, estava centrado em matérias predefinidas pelo Conselho Nacional da Educação que orientava a educação profissionalizante. Com o Parecer CNE/CEB n 17 (BRASIL, 1997), o currículo configurou-se em um meio para que alunos desenvolvam as competências profissionais previstas no perfil de conclusão.

Ainda quanto à formação com base no desenvolvimento de competências profissionais (MEC, 2000), estas envolvem saberes e operações mentais, socioafetivos e/ou psicomotores, articulados de forma a se obterem resultados produtivos de qualidade. As competências deverão oferecer condições para desenvolvimento de habilidades, isto é, capacidade de "saber fazer" que não parte de manifestação mecânica, mas de construção mental que incorpore saberes, permitindo uso fluente de técnicas e ferramentas profissionais. As competências e habilidades indicam a apropriação de bases tecnológicas ou de conjunto sistematizado de conceitos, normas, métodos, técnicas, padrões, princípios e processos tecnológicos próprios da área.

Segundo relatório do Banco Mundial de 2015, o Brasil vem apresentando avanços no ensino técnico e profissional, em especial na ampliação de seu acesso e na qualidade. Cabe, entretanto, verificar a relevância e atualização dos currículos para a formação pretendida, bem como existência de adequação na pedagogia em função das propostas (COSTIN, 2015). 


\section{5}

\section{Justificativa da pesquisa}

Este estudo trata de ensino e sua relevância foi destacada por Rui Barbosa (1882, p. 6): "[...] a inteligência e a educação constituem o mais alto de todos os valores comerciais, a nascente mais caudalosa da riqueza, a condição fundamental de toda a prosperidade. Foi assim em todos os tempos". De modo semelhante, Pacheco e Morigi (2012) atribui a nossa existência a estarmos inseridos em um contexto propício para o desenvolvimento de nossas habilidades, atribuindo à educação como sendo parte essencial na formação de um indivíduo e consequentemente de toda sociedade.

A inserção da disciplina de design gráfico no currículo do ensino fundamental (COSTA, 2013) e o ensino de design, incluindo o gráfico, em instituições de ensino superior (CARVALHO, 2012; DIAS, 2015) foram objetos de estudos recentes. No entanto, não foram identificados estudos na modalidade do ensino técnico, que é um campo complexo e multifacetado em uma área da educação formal pouco pesquisada no âmbito acadêmico, configurando-se uma oportunidade de pesquisa. Além disso, os primórdios do ensino de design no Brasil remontam a escolas técnicas, e estas por sua vez, indiretamente, dão origem aos ensinos superiores de design (NIEMEYER, 2007; LEON, 2014).

Deste modo, como justificativa da pesquisa, buscou-se produzir uma radiografia do ensino técnico de design gráfico em São Paulo (2018 - 2019); produzir elementos de registro e memória de práticas pedagógicas no âmbito do ensino técnico de design gráfico em São Paulo, identificando suas naturezas, principais atores envolvidos, instituições etc; fornecer subsídios, indicações e diretrizes para elaboração de currículos mais eficientes para o ensino de design gráfico no âmbito do ensino técnico; contribuir para formação de profissionais melhor preparados para o mercado de trabalho. 


\section{6}

\section{Definições de conceitos}

\subsection{1}

\section{Ensino técnico}

É um nível ou subsistema de ensino enquadrado no nível médio dos sistemas educativos, referindo-se à educação realizada em escolas secundárias ou outras instituições que conferem diplomas profissionais. Constitui modalidade de ensino vocacional, orientada para rápida integração do aluno no mercado de trabalho, com caraterísticas específicas que podem variar conforme o país e seu sistema educativo. Normalmente, corresponde a formação ao nível do ensino secundário, incluindo tanto os níveis 3 e 4 da Classificação Internacional Normalizada da Educação. (EDUCALINGO)

\subsection{2}

\section{Design gráfico}

É um processo técnico e criativo que utiliza imagens e textos para comunicar mensagens, ideias e conceitos, com objetivos comerciais ou de fundo social. (ADG, 1998)

\subsection{3}

\section{Comunicação visual}

É a capacidade de trabalhar com conteúdo por meio da linguagem visual, isto é, de dar visualidade às mensagens e estabelecer qual a melhor maneira de transmitir visualmente um determinado conteúdo. (FORMIGA, 2011)

\subsection{4}

\section{Competência}

Competência designa saber ser, mais do que saber fazer e implica dizer que o trabalhador competente é aquele que sabe utilizar todos os seus conhecimentos, obtidos através de vários meios e recursos, nas mais diversas situações encontradas em seu posto de trabalho. (DESAULNIERS, 1993, p. 100)

Neste estudo, as expressões comunicação visual e design gráfico são empregadas indistintamente como termos sinonímicos, de maneira intercambiável. 


\section{7}

\section{Pressuposições}

\subsection{1}

Esta pesquisa se baseia na pressuposição de que o país necessita da atividade de design gráfico para se desenvolver e aprimorar a qualidade de vida de seus cidadãos e que o mercado de trabalho demanda profissionais qualificados para desempenhar tarefas técnicas relacionadas a este campo.

\subsection{2}

Pressupõe, também, que cursos técnicos de design gráfico, apesar de receberem influências de outros cursos, tenham especificidades próprias e que existam aspectos importantes e significativos a serem identificados, em um estudo de reconhecimento, em escolas selecionadas de ensino técnico de design gráfico.

\subsection{3}

Pressupõe, ainda, que os resultados desta investigação poderão propiciar melhor entendimento a respeito desses vários aspectos e demais particularidades desse ensino na modalidade técnica, contribuindo como referência para outros cursos de design e de áreas correlatas.

\section{8}

\section{Delimitações da pesquisa}

\subsection{1}

Sendo o objeto deste estudo a pedagogia do design gráfico no ensino técnico, não se pretende abordar cursos livres de design, posto que a modalidade técnica de ensino tenha especificidades próprias.

\subsection{2}

Este estudo não se configura em um apanhado histórico do processo de implantação e desenvolvimento de escolas técnicas na cidade de São Paulo. Trata-se, especificamente, de uma investigação de práticas pedagógicas correntes, em 2018 e 2019, de ensino de design gráfico, sobretudo em duas das 10 escolas de ensino técnico de design gráfico na cidade de São Paulo. 


\section{9}

\section{Eticidade da pesquisa}

Todos os participantes, aqui denominados "respondentes" concordaram em colaborar com a pesquisa, permitindo que as informações por eles concedidas fossem publicadas. De início, houve compromisso de explicitar, de maneira clara, a natureza, métodos e objetivos desta investigação e garantir o conforto físico e psicológico dos participantes, assegurando-lhes sigilo de suas identidades.

As entrevistas contaram com o apoio de gravações em áudio e registros fotográficos. Apenas um participante, das 38 entrevistas realizadas, manifestou desejo de que a conversa não fosse gravada em áudio. Nesse caso, utilizou-se a técnica de anotação das informações.

O local para realização das entrevistas se configurou, essencialmente, na própria instituição de ensino. No caso de egressos de cursos técnicos, alguns depoimentos ocorreram no ambiente de trabalho do respondente, nas dependências de suas faculdades ou mesmo, na própria FAU USP. 
2

Quadro referencial teórico

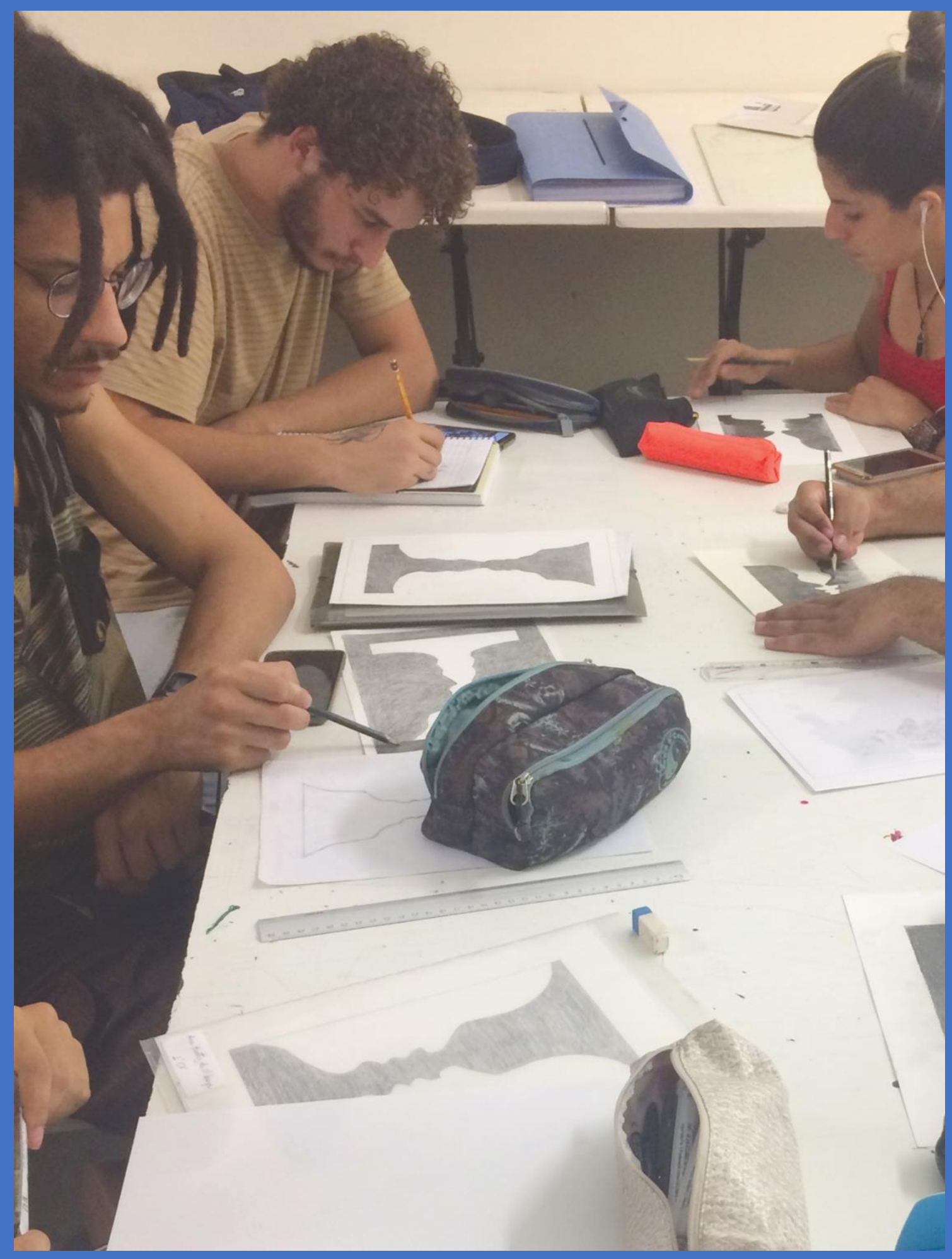




\section{Quadro referencial teórico}

\section{0}

\section{Considerações gerais sobre a revisão da literatura correlata}

Nesta revisão preliminar da literatura correlata, buscou-se identificar autores e estudos que, de alguma maneira, tangenciaram a temática desta proposta, colaborando para justificar sua pertinência e introduzir algumas possíveis discussões a respeito do objeto da pesquisa, que diz respeito à pedagogia do design gráfico no ensino técnico na cidade de São Paulo.

\section{1}

\section{Iniciativas pioneiras do ensino técnico de design na Europa}

No contexto europeu do século XIX se aceita uma passagem gradual do aprendizado tradicional em oficinas e fábricas para um cenário de ensino profissionalizante em escolas e universidades. A primeira Exposição Universal da Indústria, em 1851, realizada em Londres, aprofundou debates e reflexões teóricas relativas ao ensino artístico para fins industriais na Inglaterra, França e Alemanha. Tais escritos defendiam o design e, portanto, a formação dos designers, como fator decisório no êxito dos produtos industrializados no mercado internacional. Assim, essas ideias contribuíram para a reforma total do sistema britânico de ensino técnico-artístico, colocando as Schools of Design sob o respaldo do futuro sistema de South Kensington, após 1853.

De modo semelhante, alguns artistas e industriais franceses iniciaram, a partir de 1858, a formação de uma sociedade para promover a junção de arte e indústria, que viria a constituir-se na Union Centrale des Arts Décoratifs, colaborando, de modo significativo, com a reforma do ensino técnico-artístico na França durante a segunda metade do século XIX. A intenção era o de fornecer conhecimento artístico e científico a artesãos e operários ligados aos ofícios mecânicos, com o propósito maior de inserir o trabalhador na nova ordem industrial. 
Para Cardoso (2008), "[...] a desvalorização e o desprezo sofridos pelas academias, [...], a partir do final do século XIX, remontam ao longo processo de renegamento dos aspectos mecânico e braçal do fazer artístico, que se cristalizou [...] com o surgimento das novas escolas técnicas". Essa grande exposição de 1851 repercutiu no Brasil, justificando tanto a efetiva implantação do ensino de artes e ofícios na Academia Imperial de Belas Artes (Aiba), por Manuel de Araújo Porto-Alegre, como a criação do Liceu de Artes e Ofícios no Rio de Janeiro, em 1856, por Francisco Joaquim Béthencourt da Silva.

Anos mais tarde, em 1882, Rui Barbosa, em referência à exposição de 1851, apontaria que o desleixo do ensino de desenho levou a Inglaterra a ser surpreendida pela superioridade dos produtos franceses. Entretanto, como expôs, ainda, Rui Barbosa, uma reforma radical desse ensino em todas as escolas inglesas levou a uma revolução em apenas 11 anos e, por sua vez, países como França, Áustria e Alemanha seguiram tal exemplo. Então, para ele: "[...] o ensino popular do desenho, que em si encerra a chave de todas as questões e de todos os destinos no domínio da arte, é, entre todas as nações cultas, um fato total ou parcialmente consumado". (BARBOSA, R., 1882, p. 5). Desse modo, parece que Rui Barbosa, a partir do exemplo europeu, procuraria sensibilizar os brasileiros quanto ao valor do ensino do desenho para a formação de mão de obra capacitada, com vista no desenvolvimento da indústria nacional.

\section{2}

Iniciativas pioneiras do ensino técnico de design no Brasil

\subsection{1}

\section{Academia Imperial de Belas Artes (Aiba)}

No Brasil, a Academia Imperial de Belas Artes (Aiba) foi uma das instituições criadas, sob o decreto de 12 de outubro de 1816, por dom João IV, destinada a conferir uma característica ilustrada e civilizada ao Rio de Janeiro. O projeto original, concebido pelo conde da Barca, abrangia a admissão de artistas e artífices franceses para dar início ao ensino artístico e de ofícios (CARDOSO, 2008). 
Segundo Ana Mae Barbosa (2015), a Missão Francesa teria sido a primeira instituição sistemática de ensino da arte em terras brasileiras. Já Bielinski (2003) destaca a inexistência de campo e de mentalidade industrial para implantação de uma escola de artes e ofícios em uma academia de artes, situação agravada pela importação de quase tudo da Europa e desvalorização de profissões ligadas a ofícios mecânicos.

Além de brigas e falta de verbas, como apontado por Squeff (2004), o principal problema da Academia parece ter decorrido da indecisão por parte do governo, bem como de artistas e professores, quanto à função que a instituição deveria desempenhar, o que é corroborado por Cardoso (2008) ao afirmar que o insucesso do projeto inicial de ensino técnico decorreu de conflitos entre dois projetos políticos para a academia: de um lado, os franceses protegidos pelo conde da Barca e, de outro, a direção de Henrique José da Silva, apoiada no poder de Tomás Antônio de Vilanova Portugal, o qual, após a morte do conde, sucedeu-Ihe no cargo de Ministro de Estado de Negócios.

Félix Emile Taunay, já como diretor da Academia em 1834, nada fez para retomar o projeto de ensino de artes e ofícios, extinguindo, inclusive, a cadeira de mecânica. No entanto, em 1844, a partir da tarifa Alves Branco, que incluía medidas como a livre importação de maquinaria, a promulgação do Código Comercial e a proibição do tráfico negreiro, o governo imperial seguiria para uma política voltada ao crescimento da indústria. Assim, a Reforma Pedreira dentro da Aiba, em 1854, além de uma grande modificação no edifício, compreendeu a criação de novos estatutos para a instituição, abrangendo exposições públicas, premiações, entre outros e, procurando ampliar as atribuições e a importância da Academia, Porto-Alegre criaria um curso voltado ao ensino técnico. Tais estatutos conferiam grande destaque ao "ensino industrial", determinando, com acuidade, as disciplinas, carga horária e perfil do aluno para cada modalidade de curso. Para Cardoso (2008), se comparada com as academias europeias, a separação entre belas-artes e ofícios era, de certo modo, inclusiva para a época, pois possibilitava ao artífice frequentar a Aiba.

Esta relação entre arte e indústria, de acordo com Squeff (2004), configurou-se como o centro das reflexões culturais e metodológicas sobre o ensino da arte 
no Segundo Reinado. A Reforma Pedreira representou uma retomada de um projeto que caracterizara a Academia na época de sua criação, afinal, era esta associação das belas-artes e de ensino técnico que justificava sua função como instituição. Uma nova mudança nos estatutos, em 1859, apesar da saída de Porto-Alegre da direção da Aiba, garantiu a continuidade do programa industrial: tratava-se da divisão dos estudos em dois cursos, sendo um noturno, destinado a alunos em busca de aprimoramento como artífices, composto por um número bem menor de matérias em relação ao curso diurno, o que sugere intenção da Academia em enfatizar a diferenciação nos estudos das duas classes de alunos. As aulas noturnas tiveram início em 1860 e perduraram até 1888. O número muito maior de aulas de matemática nos cursos diurnos parece refletir, segundo Cardoso (2008), o que ocorrera durante a segunda metade do século XIX no ensino técnico europeu: a separação entre estudos de nível médio e superior pelo teor maior de conhecimento abstrato, sobretudo de matemáticas, em cursos mais avançados.

\subsection{2}

\section{Liceu de Artes e Ofícios (Lao-rj)}

Considera-se o Liceu de Artes e Ofícios (Lao-rj), aberto em 1858 no Rio de Janeiro pela Sociedade Propagadora das Belas-Artes (SPBA), como a mais importante instituição deste tipo de ensino em termos populares. Sua criação deve-se, sobremaneira, ao empenho do arquiteto Béthencourt da Silva com o apoio da elite intelectual do Império. De acordo com Murasse (2001), a problemática da educação fundamentava-se na necessidade de modernização dos métodos produtivos por meio da substituição do trabalho escravo pelo assalariado, do emprego gradual da maquinaria e do investimento de capitais europeus no Brasil e, sendo assim, o estabelecimento do Lao-rj decorreu da recomposição da sociedade brasileira de meados do século XIX.

O Liceu buscava, por meio do ensino gratuito de artes e ciências em aulas noturnas, elevar o Brasil ao mesmo patamar das nações mais civilizadas e, de acordo com Bielinski (2003, p. 174): "Conjugou a instrução pública à profissionalizante, com embasamento artístico e cultural”. Assim, o Lao-rj ofereceu aulas de forma 
contínua após 1858, com grande crescimento das matrículas após a obtenção de subvenção pública em 1867. Em 1881 marcou o início de aulas para mulheres e, em 1882, lançou um curso comercial. Segundo a autora, ainda, contribuiu para formação de outros liceus pelo Brasil, bem como de demais instituições, que se fundamentaram em sua experiência, diminuindo lacunas da educação pública oficial e preconceitos, sobretudo relativos à educação e profissionalização da mulher.

\subsection{3}

\section{Instituto de Arte Contemporânea (IAC)}

Fundado sob os princípios da Bauhaus de Dessau e do Institute of Design de Chicago, em 1951, o Instituto de Arte Contemporânea (IAC) do Museu de Arte de São Paulo (Masp) surgiu com o objetivo de formar técnicos aptos a atender a crescente industrialização de São Paulo nos anos 1950 (LEON, 2014), constituindo-se em espaço para a discussão sobre a relação entre design, arte, artesanato e indústria por meio de palestras, cursos e exposições (NIEMEYER, 1998). Inicialmente sem designers de formação, o curso contou com arquitetos, artistas, produtores gráficos para realizar seu programa.

A ideia de design como disciplina e atividade profissional de projeto gráfico, tridimensional ou produto, segundo Leon (2014), era inexistente antes do IAC. No Brasil, acompanhando demais países periféricos, o design gráfico e de embalagens desenvolveram-se com muito mais facilidade por não prescindirem de intervenção industrial, refletindo na atuação profissional de seus ex-alunos. Em sua visita a São Paulo para a II Bienal, Max Bill colaborou com o IAC como palestrante e motivou a ida de Alexandre Wollner para a Escola de Ulm, o qual, posteriormente, faria parte do corpo docente da Escola Superior de Desenho Industrial (Esdi). 


\subsection{4}

\section{Instituto de Arte de Decoração (ladê)}

Tendo como mentor o imigrante italiano Ítalo Bianchi (professor, cenógrafo e publicitário), o Instituto de Arte de Decoração (ladê) ofereceu seu primeiro curso de arquitetura de interiores, em 1959, com base em princípios da Bauhaus. Atribui-se, nestes primeiros anos, como diferencial, a existência de um escritório profissional na própria instituição que atendia ao mercado. Somente em 1968, o ladê passou a adequar-se ao sistema oficial de ensino técnico e, segundo Stephan e Braga (2016), seu intuito era o de formar técnicos nas áreas de artes, comunicação visual e desenho industrial, amparados na legislação da Secretaria de Educação do Estado, aptos a prestar vestibular nos cursos de arquitetura e urbanismo, desenho industrial ou comunicações, que, naquela época, estavam em processo de implantação.

\subsection{5}

\section{Universidade Mineira de Arte (UMA)}

Outra disposição se deu em Belo Horizonte com o estabelecimento, em 1957, de um curso técnico de desenho industrial na Universidade Mineira de Arte (UMA), tornando-se, em 1963, a Escola Superior de Artes Plásticas, vinculada à Fundação Mineira de Arte (Fuma). Dentre os quatro cursos oferecidos, configurava-se o de desenho industrial/comunicação visual, sendo, em 1968, reconhecido como de nível superior pelo Ministério da Educação e Cultura. Uma vez mais, em 1980, sua denominação foi alterada para Fundação Mineira de Arte Aleijadinho, constituindo-se, a partir de 1997, como Escola de Design da Universidade do Estado de Minas Gerais (Uemg) (MORAES, 2006). 


\section{3 \\ Ênfases no ensino de design}

Em relação às influências do ensino de design na FAU da USP nas décadas de 1960, Dias (2015, p. 11) aponta principalmente a recebida pela escola Bauhaus, mas também do perfil dos docentes, artistas plásticos e arquitetos, que sinalizaram visões distintas: uma baseada na sensibilidade artística e outra na metodologia de projeto. De modo similar, Carvalho (2012, p. 80) credita a essa escola: "[...] quanto à Comunicação Visual, o corpo docente sugeriu, principalmente, trabalhos que explorassem a 'expressão livre' e a 'capacidade criativa', como o ensino desenvolvido no curso básico da Bauhaus". Assim como nos primórdios do ensino de comunicação visual na FAU, mostrou-se pertinente a identificação de aspectos que, de alguma maneira, teriam influenciado a configuração dos cursos técnicos de design gráfico, bem como do perfil dos professores atuantes.

Quanto ao papel do projeto, Dias (2015, p. 86) destaca sua importância no ensino de comunicação visual. Segundo ela, "[...] algumas das incumbências das disciplinas que serviram de raízes para a Sequência de Comunicação Visual foram delegadas à Sequência de Projeto", o que corrobora Carvalho (2012) ao enfatizar o ensino de projeto como espinha dorsal do Curso. Já Bonsiepe (2011, p. 224) alerta para o afastamento, nos anos 1990, do conceito de design da categoria de projeto, com sua associação a aspectos comunicativos caros, pouco práticos e esteticamente vistosos. Em vista destes pareceres relativos ao ensino da comunicação visual na graduação, configurou-se relevante o entendimento da função do projeto em sua modalidade técnica.

Para uma nova prática de ensino de design, Bonsiepe (2015, p. 172) retoma a temática da linguagem como terreno fértil, cultivado no programa da Escola de Ulm. Complementarmente, Cardoso (2013, p. 246) acredita que o melhor estímulo para o desenvolvimento da criatividade no ensino de design seria promover o intercâmbio com as demais áreas que visam à criação plástica, formal ou visual. Para ele, "A possibilidade de inovação projetista está intimamente associada à inventividade de linguagem". Nesse sentido, a compreensão das diversificadas linguagens visuais apresentadas e materializadas em resultados de exercícios de projeto de design gráfico de alunos cursando o ensino técnico demonstrou ser importante para esta pesquisa. 
Por sua vez, Costa (2013), em sua pesquisa sobre inserção da disciplina de comunicação visual no ensino fundamental regular, afirma que as atividades educacionais de design demandariam participação ativa do aluno para sua realização, colaborando para que crianças e jovens desenvolvam estratégias para a construção de seus repertórios de conhecimento. Assim, o conhecimento de que determinadas atividades de design seriam motivadoras para a estruturação de um conjunto de saberes na modalidade técnica também se mostrou significativo para este estudo.

Segundo Fontoura (2002, p. 277), sendo interdisciplinar o design, pareceria natural que um designer caminhasse por campos de conhecimentos fora de sua área de atuação. Para ele, "[...] é comum proceder desta forma pois quando assim o faz, está em busca de informações que permitam uma compreensão maior do problema que pretende resolver". Em termos de ensino, de acordo com essa visão, atividades de design possibilitariam a jovens entrar em contato com diversificadas áreas, contribuindo para uma formação mais abrangente e eficaz. De maneira semelhante, Costa (2013) aponta que, por meio de atividades de design, jovens desenvolveriam habilidades importantes como, por exemplo, resolução criativa de problemas, auto-organização, trabalho com ferramentas e materiais, tornando-os aptos a tomar decisões fundamentadas. Desse modo, o desenvolvimento de tais habilidades mostra-se relevante para qualquer modalidade de ensino de design.

\section{4}

\section{Diferencial do ensino técnico}

Em relação ao diferencial do ensino técnico, Scacchetti (2013) aponta que esse se distingue pela utilização de laboratórios, proporcionando aos estudantes maior interação entre teoria e prática. De modo complementar, Bonsiepe (2015, p. 171) ressalta a necessidade de apresentar-se uma base teórica no ensino de design, já que: "Um ensino orientado somente à prática não acerta a prática". Nesse sentido, parece relevante se identificar o conteúdo e a pertinência do referencial teórico para dar suporte à prática em cursos técnicos de design.

Quanto à formação dos docentes do ensino técnico, Claudino (2011, p. 126) enfatiza a conveniência de conhecimento do mundo do trabalho, da prática, da pesquisa, da educação continuada, da promoção da interdisciplinaridade e contextualização 
pedagógica. Já Musto (2008, p. 10) destaca que a bagagem pessoal de cada professor seria, em certa maneira, refletida em suas aulas, pois: "Toda a gama de expectativas e crenças que os professores levam para o momento educacional, influenciando o ato educativo, está intimamente relacionada àquelas questões de capital cultural e o habitus em cada um deles". Complementarmente, Cardoso (2013, p. 239) declara a importância do professor no processo de aprendizagem, pois, segundo ele, "Os melhores mestres hoje são aqueles que mantém a curiosidade e a abertura dos iniciantes, completando o ciclo e transformando o aprendizado em processo contínuo". Assim, de acordo com tais autores, o conhecimento abrangente do perfil dos docentes possibilitaria um entendimento mais especialmente claro a respeito de vários aspectos dos cursos técnicos.

\section{5}

\section{Importância do ensino técnico de design}

Antes do uso corrente dos termos design e usuário, Rui Barbosa, ao final do século XIX, sustentava a educação pela arte como formadora da população:

O fim da educação Contemporânea pela arte não é promover individualidades extraordinárias, mas educar esteticamente a massa geral das populações, formando, a um tempo, o consumidor e o produtor, determinando simultaneamente a oferta e a procura nas indústrias do gosto. (BARBOSA, R., 1882, p. 8).

Tal consideração parece, ainda, bastante atual e coaduna-se com a de Bielinski (2003, p. 174) ao se referir à relevância das escolas pioneiras de arte e ofícios no século XIX, destacando que procuraram "[...] transformar os antigos e arraigados 'pré-conceitos' em relação às artes e ofícios, e também estabelecer o desenho industrial, cujo estudo e aplicação tornariam nossos produtos industriais elaborados e competitivos", e, além disso, instituíram um novo nível para as artes e ofícios ao implementarem o ensino técnico-profissionalizante com base no desenho.

Ainda Rui Barbosa, em seu discurso, "O desenho e a arte industrial", defendeu a importância deste ensino no âmbito do social: 
A educação industrial representa um dos auxiliares mais eficazes no nivelamento crescente das distinções de classes entre os homens, não deprimindo as superioridades reais, mas destruindo as inferioridades artificiais, que alongam dessa eminência as camadas laboriosas do povo, isto é, elevando a um plano cada vez mais alto a ação e o pensamento do operário. (BARBOSA, R., 1882, p. 18).

Para ele, o ensino técnico seria a base para a industrialização do Brasil e, aliando-se ao ensino de qualquer das modalidades de desenho, de modo abrangente para todas as idades e camadas sociais, contribuiria para a passagem de um país agrário a um país industrial: "O dia em que o desenho e a modelação começarem a fazer parte obrigatória do plano de estudos na vida do ensino nacional datará o começo da história da indústria e da arte no Brasil" (BARBOSA, R., 1882, p. 16).

O projeto de ensino do desenho de Rui Barbosa, segundo Ana Mae Barbosa (2015), configurou-se como o mais detalhado e embasado que se apresentara à legislação brasileira. Mesmo com a proposta não aprovada oficialmente, seu projeto resistiu, como agenda escondida nas escolas brasileiras, até início dos anos 1980, por interesse social e político. Na época, evidenciava-se uma explosão da construção civil e os abolicionistas desejavam que a escola pública e as oficinas habilitassem os escravos recém-libertos em desenho decorativo e desenho gráfico para serem especializados e bem pagos.

Já no século XX, o modelo educacional configurado como a primeira fase da virada modernista, apoiado por educadores com formação estruturada, propiciou a criação e reformulação de escolas profissionais, reforçando-se o ensino do desenho para formar mão de obra especializada. Para Barbosa, A. M. (2015, p. 18), "[...] foi nas escolas profissionais que se deu o início do que se chamava Artes Gráficas ou Desenho Gráfico - que foi discutido, avaliado e implementado". Por isso, segundo a autora, "[...] Temos um Design Gráfico modernista contemporâneo extraordinariamente bom, porque fomos cedo iniciados nas Artes Gráficas nas Escolas Profissionais". Sua afirmação aponta para o valor atribuído ao ensino profissional das artes gráficas na estruturação do ensino gráfico no país. 
Método de pesquisa

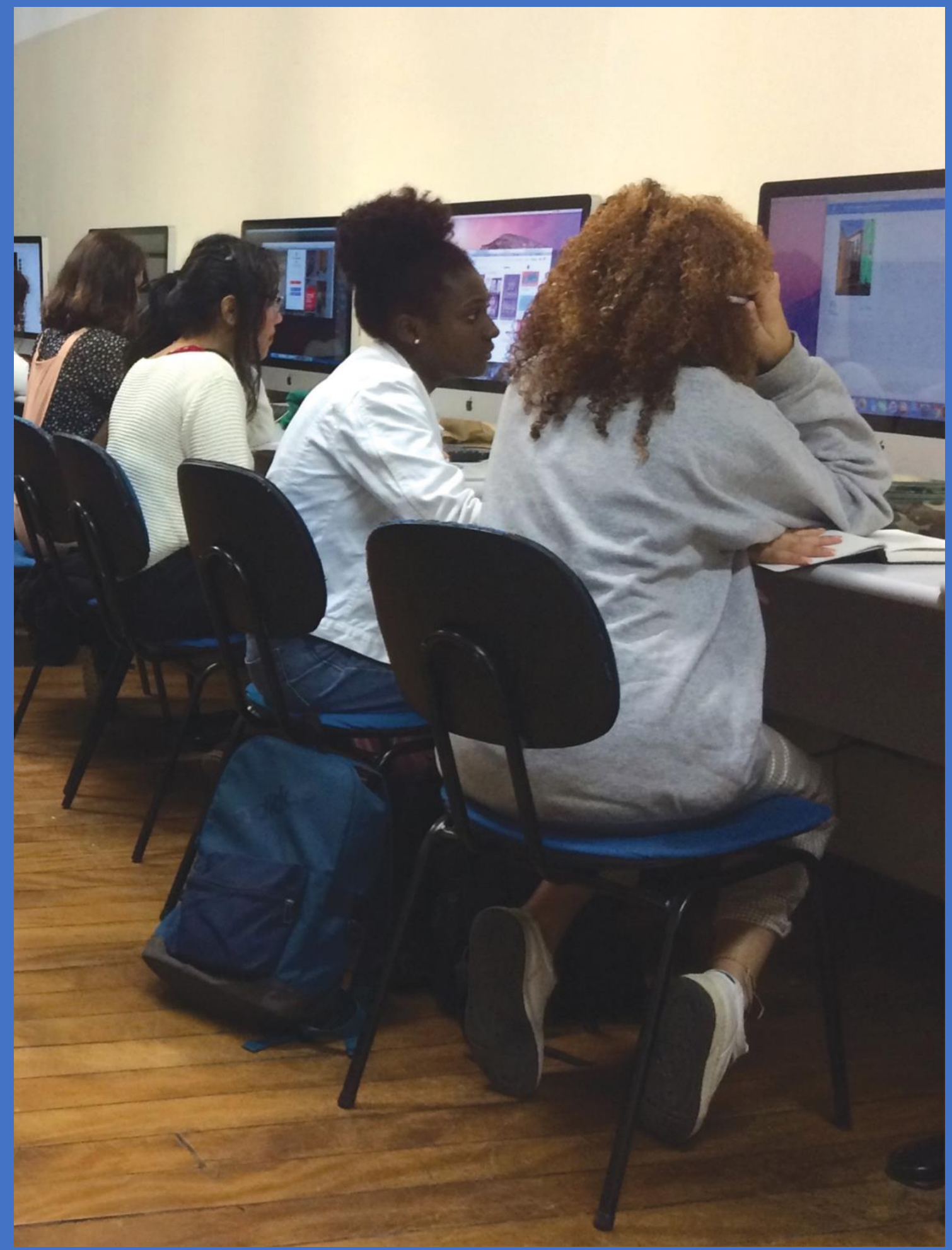


3

\section{Método de pesquisa}

\section{0}

\section{Considerações gerais sobre o método da pesquisa}

Esta pesquisa de mestrado se propôs a conduzir uma investigação qualitativa de reconhecimento de aspectos relevantes do estado dos cursos técnicos de design gráfico na cidade de São Paulo, em 2018 e 2019, visando fornecer subsídios, indicações e diretrizes que possam contribuir para elaboração de currículos mais eficientes para a pedagogia de design gráfico no âmbito do ensino técnico. Tal propósito se insere no objetivo mais amplo de formar profissionais melhor preparados para o mercado de trabalho. Os aspectos observados na investigação incluem: aspectos do universo de seus alunos, do perfil de professores, de estruturas materiais e físicas disponíveis, de abordagens pedagógicas praticadas, de elementos de metodologia de projeto de design exercitados com os alunos, de linguagens visuais características de trabalhos de alunos, e de questões ainda mais gerais intrínsecas à natureza do ensino técnico de design.

O estudo se apoiou, sobretudo, em pesquisas de campo em duas das dez escolas que oferecem cursos técnicos de design gráfico na cidade de São Paulo, a saber: a rede estadual de Escolas Técnicas de São Paulo, as Etecs, e no do Serviço Nacional de Aprendizagem Comercial (Senac-SP) (Mapa 1). Teve a bibliografia como aporte teórico nas áreas de ensino de design, particularmente compreendendo trabalhos que se dedicaram à discussão e à compreensão de aspectos fundamentais do ensino de design gráfico, além de estudos sobre o ensino técnico, sua realidade e características próprias.

A técnica para coleta de dados utilizada foi a entrevista semiestruturada em profundidade, aplicadas a coordenadores, professores e alunos, conduzidas no próprio ambiente escolar, bem como de egressos destes cursos técnicos. Além disso, foram realizadas observações discretas de aulas, análise dos materiais de aula e de apoio, acompanhamento a visitas técnicas, observações de apresentações de Trabalhos de Conclusão de Curso (TCCs), análises gráficas 
e semióticas da linguagem visual de pranchas de trabalhos executados por alunos, entre outros. A pesquisa também se apoiou em registros fotográficos.

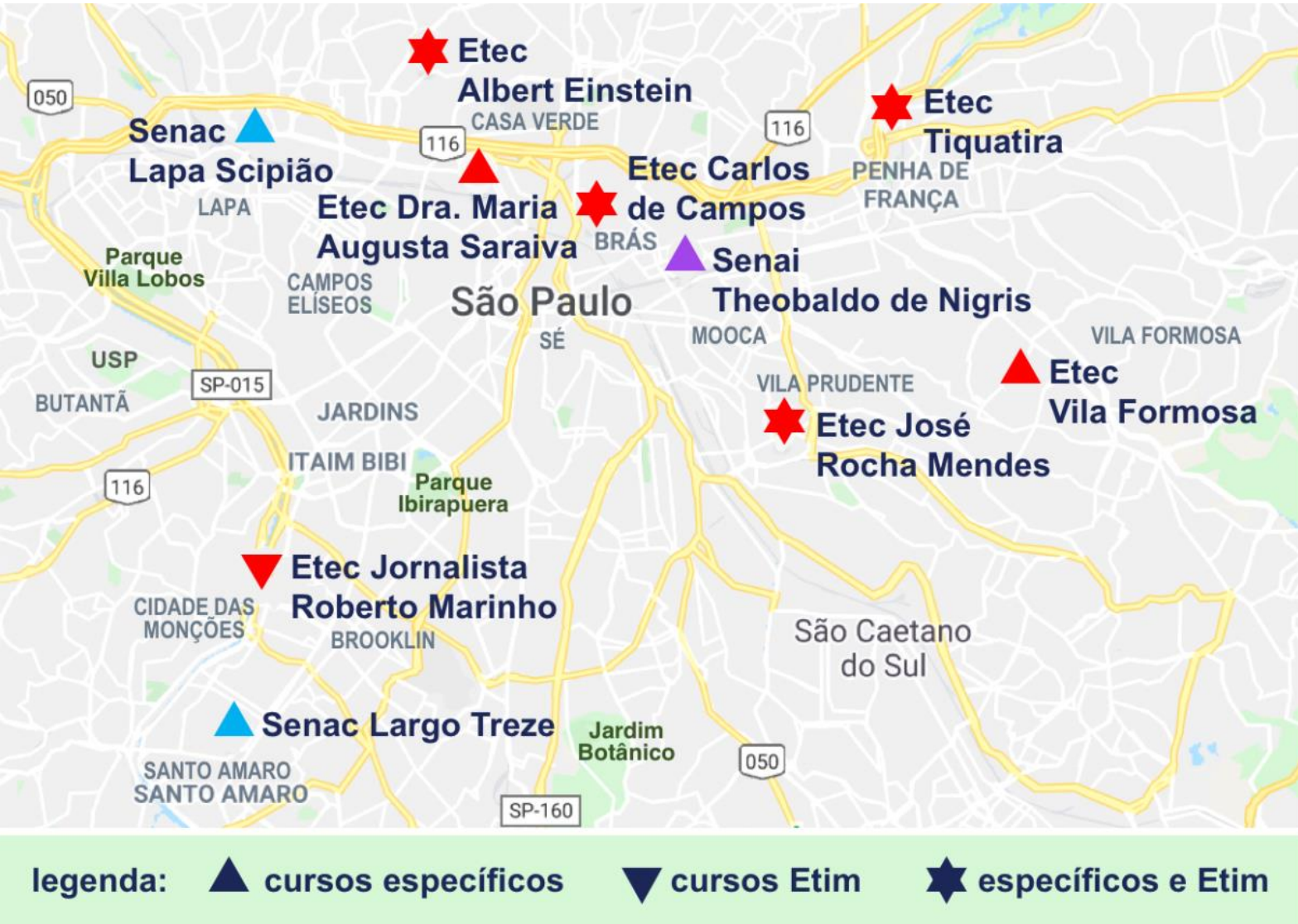

Mapa 1 - distribuição geográfica das escolas técnicas com cursos de design gráfico (ou comunicação visual) na cidade de São Paulo, em 2019

Fonte: a autora

Após as entrevistas, o material foi transcrito e, juntamente com as anotações da pesquisadora, compuseram os dados brutos coletados em forma de texto. Realizou-se uma análise associativa a partir da sistematização dos dados brutos coletados junto a coordenadores, professores, alunos e ex-alunos, buscando identificar padrões abstratos de associação. Buscou-se, ainda, analisar os registros fotográficos das visitas nas escolas e em atividades externas, bem como de trabalhos de alunos. Organizou-se os dados em aspectos do universo de seus alunos, do perfil de professores, de estruturas materiais e físicas disponíveis, de abordagens pedagógicas praticadas, de metodologia de projeto de design exercitados com os alunos, de linguagens visuais presentes em resultados de trabalhos de alunos e de questões ainda mais gerais intrínsecas à natureza do ensino técnico de design. 


\subsection{1}

Diagrama das coordenadas de localização conceitual da pesquisa

Para situar a grande área, campo, subárea e zona de interesse que se insere

o presente estudo e identificar os elementos constitutivos da questão fundamental norteadora deste trabalho (objeto, enfoque e recorte), dispõem-se, a seguir, o diagrama conceitual de localização da pesquisa, formado por quatro pranchas. 
1. grande área:

ciências sociais aplicadas

2. campo:

design (ou desenho industrial)

3. subárea:

design gráfico (ou programação visual)

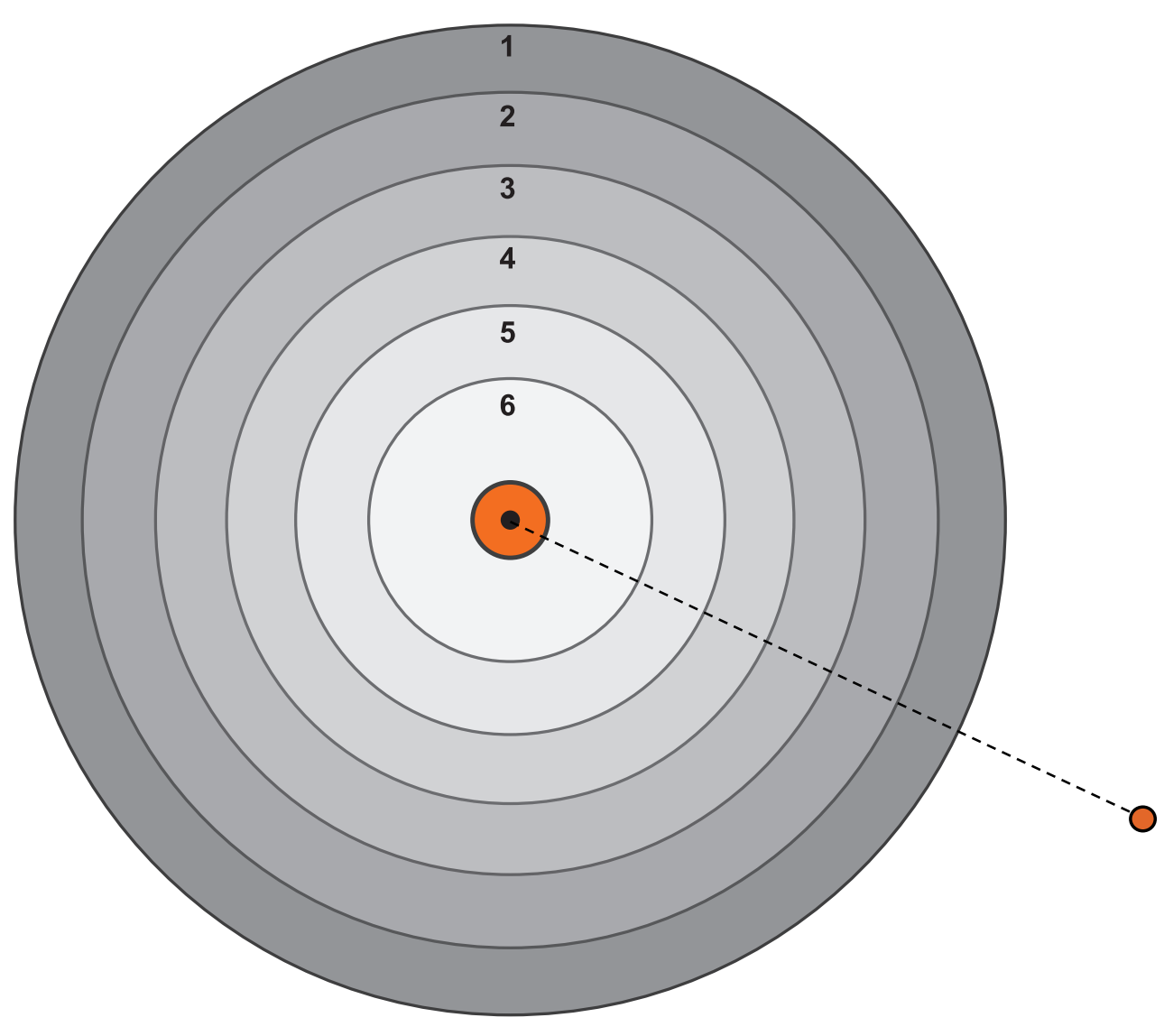

4. especialidade:

ensino de design gráfico

5. zona de interesse:

ensino técnico de design gráfico

6. objeto:

pedagogia do design gráfico no ensino técnico na cidade de São Paulo

\section{9. questão fundamental:}

Que aspectos relevantes podem ser identificados, por meio de estudo qualitativo de reconhecimento da realidade do ensino técnico de design gráfico na cidade de São Paulo, em 2018 e 2019, em termos do universo de seus alunos, do perfil de professores, de estruturas materiais e físicas disponíveis, de abordagens pedagógicas praticadas, de elementos de metodologia de projeto de design exercitados com os alunos, de linguagens visuais características de trabalhos de alunos e de questões ainda mais gerais intrínsecas à natureza do ensino técnico de design, com base em pesquisas de campo realizadas, sobretudo, em duas das dez escolas de 


\section{Diagrama das coordenadas de localização conceitual da pesquisa}

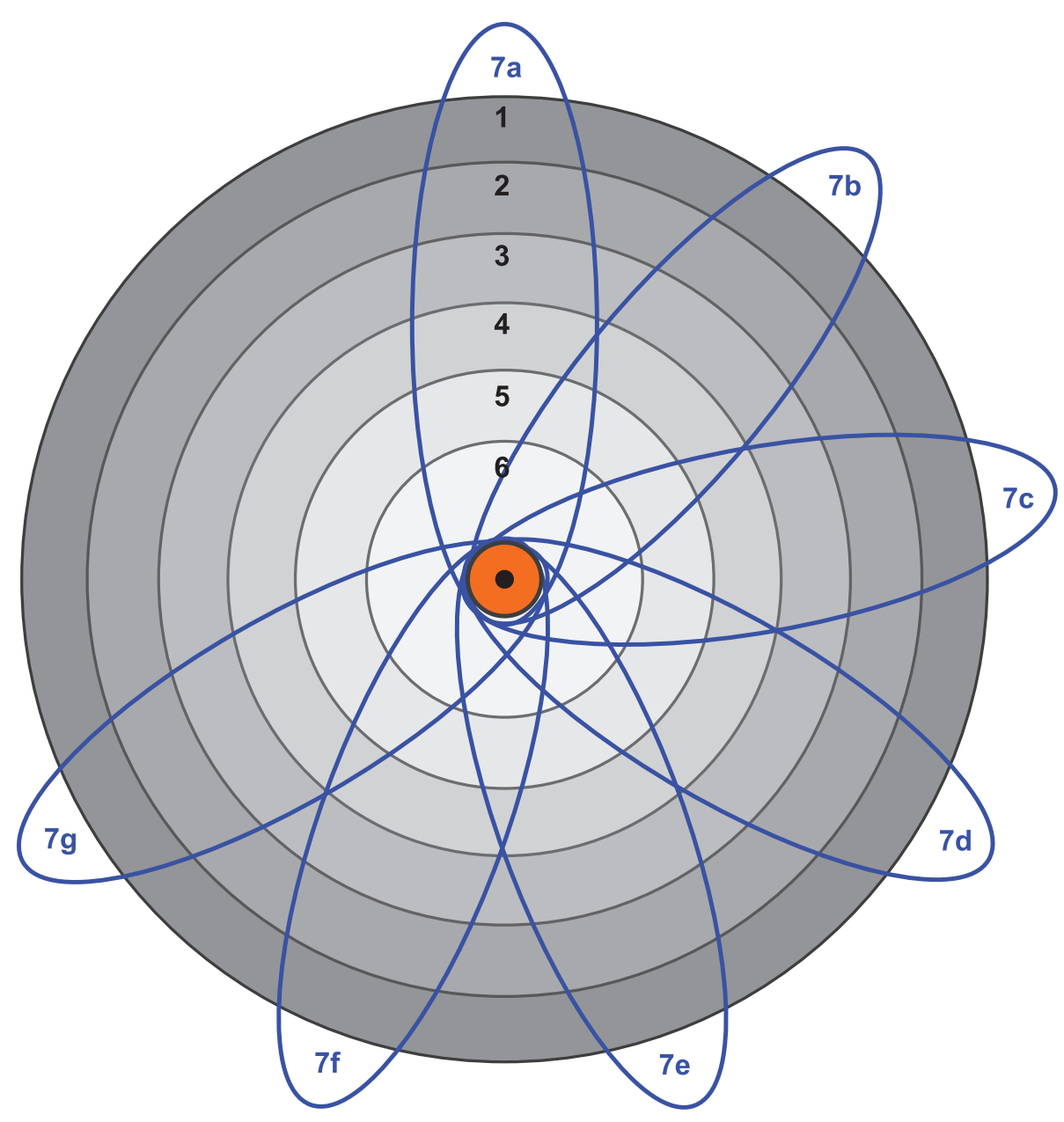

Prancha $2 / 4$
1. grande área:

ciências sociais aplicadas

2. campo:

design (ou desenho industrial)

3. subárea:

design gráfico (ou programação visual)

4. especialidade:

ensino de design gráfico

5. zona de interesse:

ensino técnico de design gráfico

\section{6. objeto:}

pedagogia do design gráfico no ensino técnico na cidade de São Paulo

7. enfoque:

7a. universo de seus alunos, 7b. perfil de seus professores, 7c. estruturas materiais e físicas disponíveis, $7 \mathrm{~d}$. abordagens pedagógicas praticadas, 7e. elementos de metodologia de projeto de design exercitados com os alunos, $7 \mathrm{f}$. linguagens visuais características de trabalhos de alunos 7g. questões ainda mais gerais intrínsecas à natureza do ensino técnico de design

\section{9. questão fundamental:}

Que aspectos relevantes podem ser identificados, por meio de estudo qualitativo de reconhecimento da realidade do ensino técnico de design gráfico na cidade de São Paulo, em 2018 e 2019, em termos do universo de seus alunos, do perfil de professores, de estruturas materiais e físicas disponíveis, de abordagens pedagógicas praticadas, de elementos de metodologia de projeto de design exercitados com os alunos, de linguagens visuais características de trabalhos de alunos e de questões ainda mais gerais intrínsecas à natureza do ensino técnico de design, com base em pesquisas de campo realizadas, sobretudo, em duas das dez escolas de ensino técnico de design gráfico em atividade na cidade de São Paulo? 
1. grande área:

ciências sociais aplicadas

2. campo:

design (ou desenho industrial)

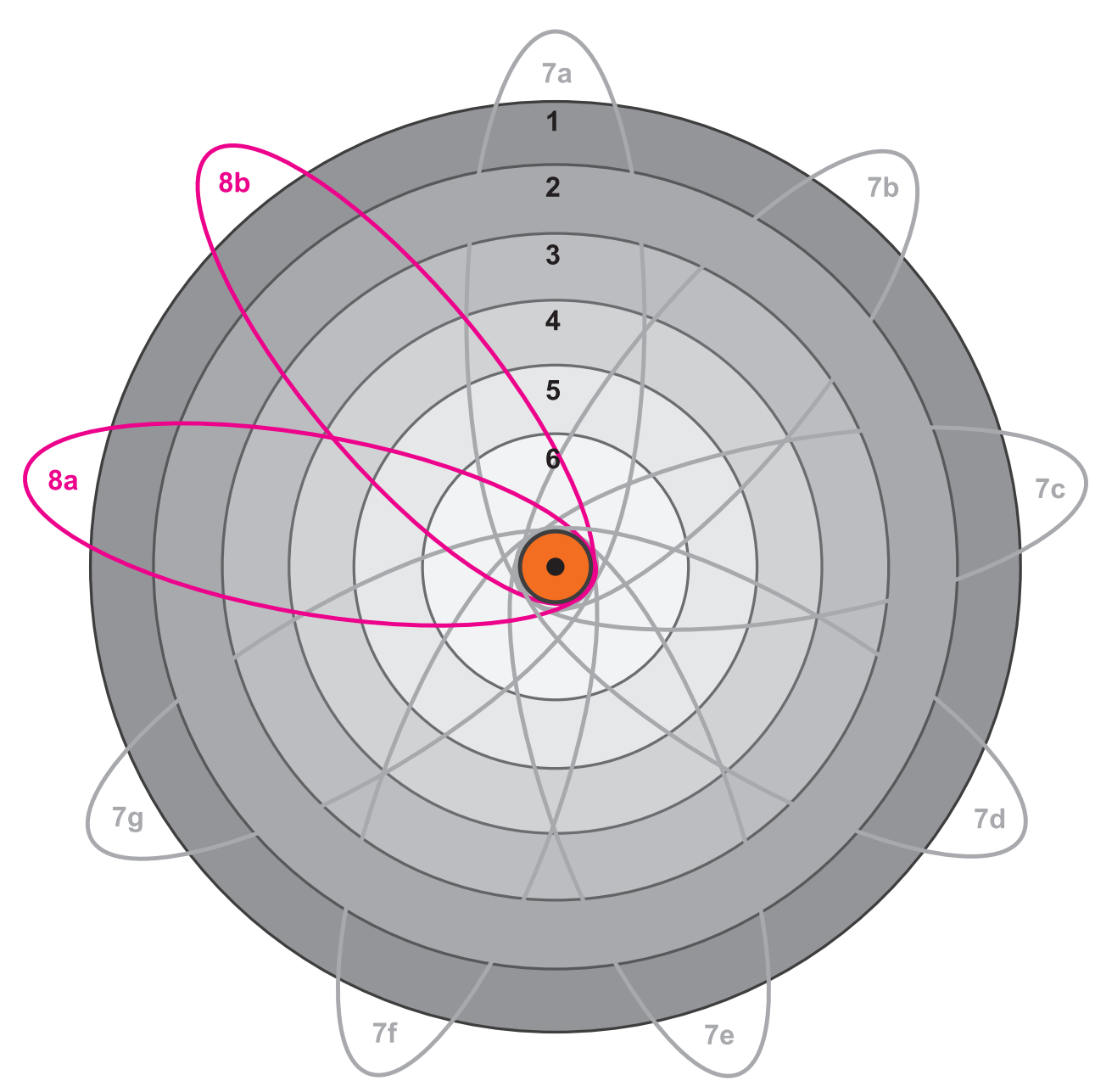

3. subárea:

design gráfico (ou programação visual)

4. especialidade:

ensino de design gráfico

5. zona de interesse:

ensino técnico de design gráfico

6. objeto:

pedagogia do design gráfico no ensino técnico na cidade de São Paulo

\section{7. enfoque:}

7a. universo de seus alunos, 7b. perfil de seus professores, 7c. estruturas materiais e físicas disponíveis, $7 \mathrm{~d}$. abordagens pedagógicas praticadas, 7 e. elementos de metodologia de projeto de design exercitados com os alunos, $7 \mathrm{f}$. linguagens visuais características de trabalhos de alunos $7 \mathrm{~g}$. questões ainda mais gerais intrínsecas à natureza do ensino técnico de design

8. recorte:

8a. duas das dez escolas de ensino técnico de design gráfico em atividade na cidade de São Paulo

8b. em 2018 e 2019

9. questão fundamental:

Que aspectos relevantes podem ser identificados, por meio de estudo qualitativo de reconhecimento da realidade do ensino técnico de design gráfico na cidade de São Paulo, em 2018 e 2019, em termos do universo de seus alunos, do perfil de professores, de estruturas materiais e físicas disponíveis, de abordagens pedagógicas praticadas, de elementos de metodologia de projeto de design exercitados com os alunos, de linguagens visuais características de trabalhos de alunos e de questões ainda mais gerais intrínsecas à natureza do ensino técnico de design, com base em pesquisas de campo realizadas, sobretudo, em duas das dez escolas de ensino técnico de design gráfico em atividade na cidade de São Paulo?

Prancha $3 / 4$ 
1. grande área:

ciências sociais aplicadas

2. campo:

design (ou desenho industrial)

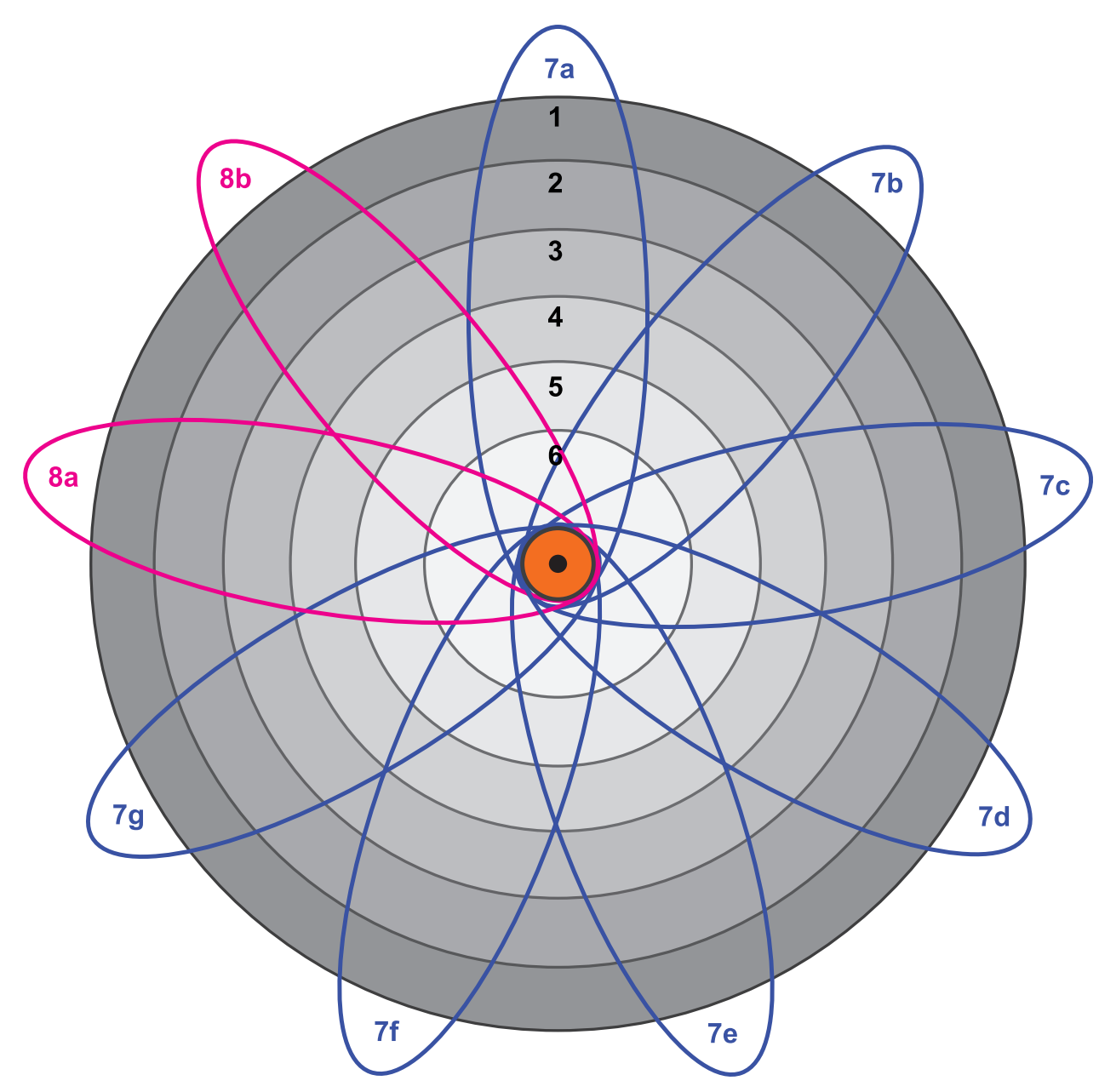

3. subárea:

design gráfico (ou programação visual)

4. especialidade:

ensino de design gráfico

5. zona de interesse:

ensino técnico de design gráfico

\section{6. objeto:}

pedagogia do design gráfico no ensino técnico na cidade de São Paulo

\section{7. enfoque:}

7a. universo de seus alunos, 7b. perfil de seus professores, 7c. estruturas materiais e físicas disponíveis, $7 \mathrm{~d}$. abordagens pedagógicas praticadas, 7 e. elementos de metodologia de projeto de design exercitados com os alunos, $7 \mathrm{f}$. linguagens visuais características de trabalhos de alunos $7 \mathrm{~g}$. questões ainda mais gerais intrínsecas à natureza do ensino técnico de design

\section{8. recorte:}

8a. duas das dez escolas de ensino técnico de design gráfico em atividade na cidade de São Paulo

8b. em 2018 e 2019

\section{9. questão fundamental:}

Que aspectos relevantes podem ser identificados, por meio de estudo qualitativo de reconhecimento da realidade do ensino técnico de design gráfico na cidade de São Paulo, em 2018 e 2019, em termos do universo de seus alunos, do perfil de professores, de estruturas materiais e físicas disponíveis, de abordagens pedagógicas praticadas, de elementos de metodologia de projeto de design exercitados com os alunos, de linguagens visuais características de trabalhos de alunos e de questões ainda mais gerais intrínsecas à natureza do ensino técnico de design, com base em pesquisas de campo realizadas, sobretudo, em duas das dez escolas de ensino técnico de design gráfico em atividade na cidade de São Paulo? 


\subsection{2}

Quadros sinóticos da estrutura metodológica da pesquisa e da estrutura da dissertação

Com o propósito de organizar e promover uma visualização do conjunto de informações referentes à estrutura metodológica da pesquisa, elaborou-se um quadro sinótico. Foi produzido, ainda, um segundo quadro, nomeado de "estrutura da dissertação", que permite relacionar a estrutura metodológica da pesquisa com a da estrutura desta dissertação de mestrado.

\subsubsection{1}

Quadro sinótico da estrutura metodológica da pesquisa

(apresentado na página subsequente) 

\begin{tabular}{|l|}
\hline Objeto \\
\hline \\
\hline Titulo \\
\hline
\end{tabular}

Pedagogia do design graficico no ensino técnico na cidade de Săo Paulo

Ensino tecrico de design graficico na cidade de Săo Paulo

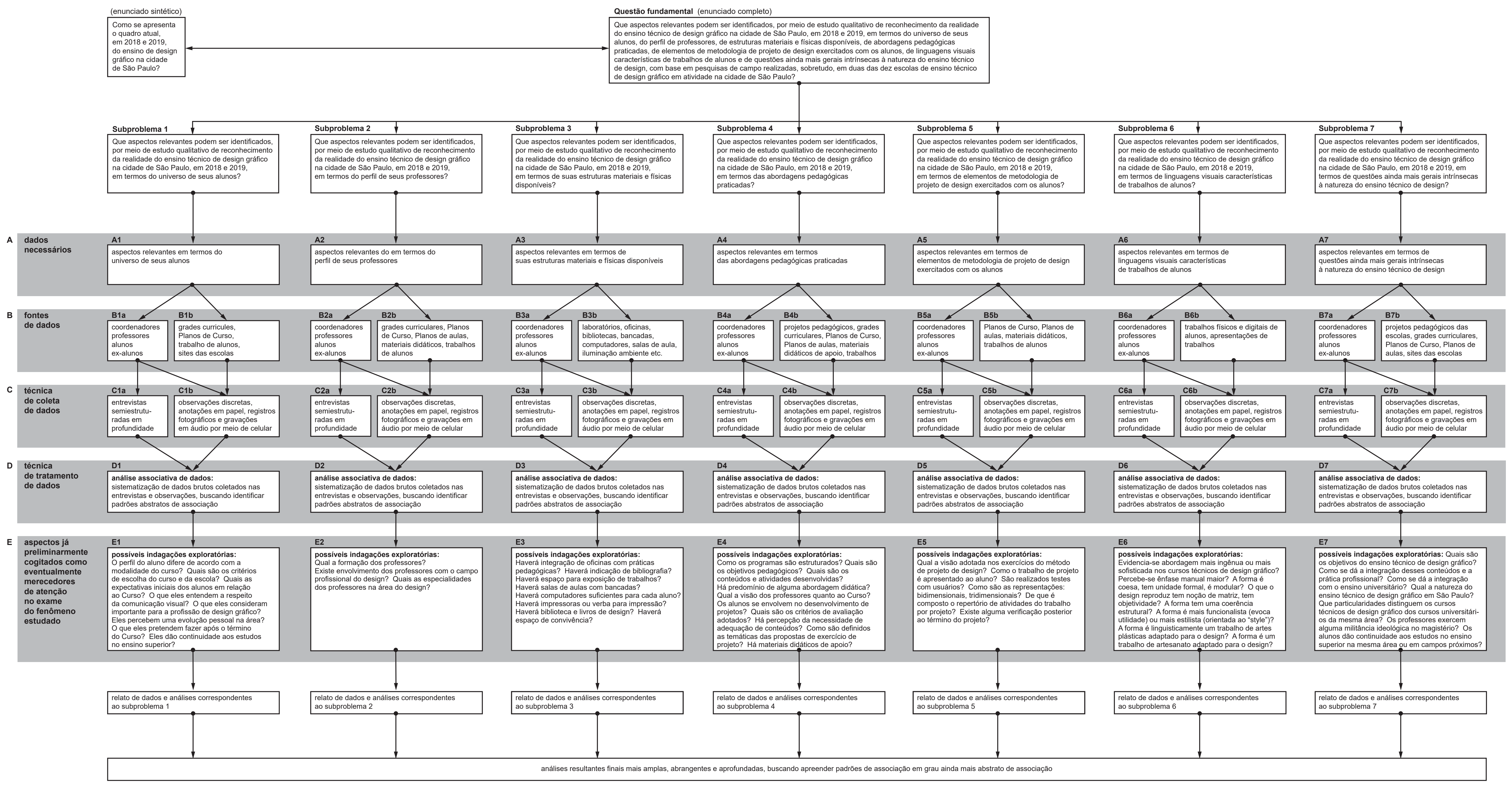




\subsubsection{2}

Quadro sinótico da estrutura da dissertação

(apresentado na página subsequente) 
ine-entos
pro-textuais

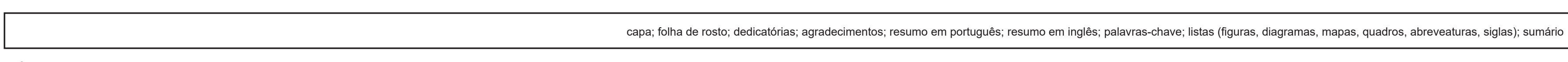

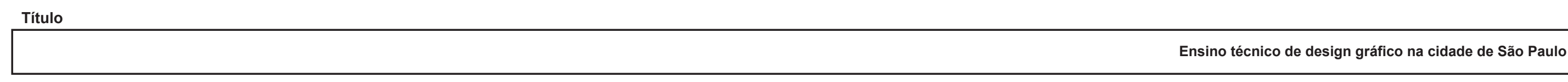

cap. 1 Caracterização

geral

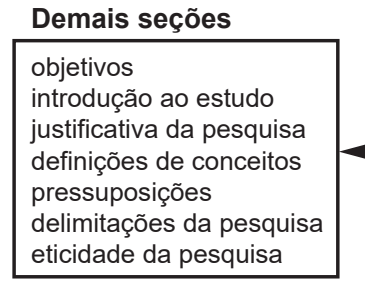

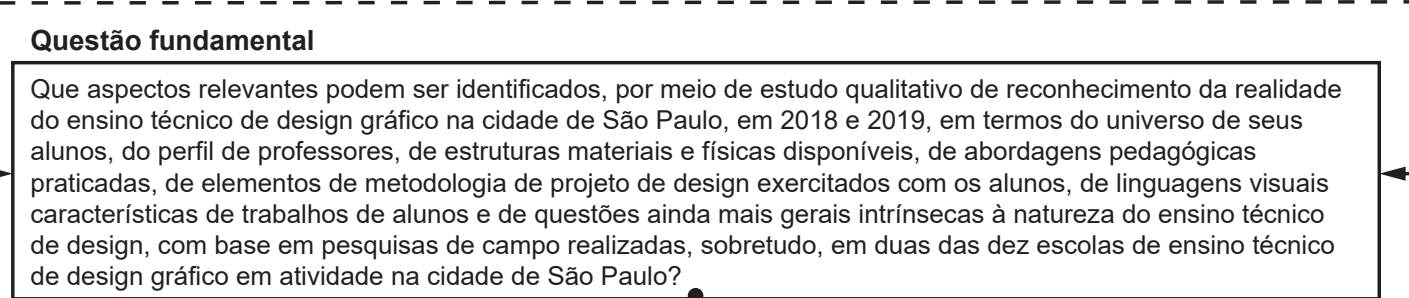

\begin{tabular}{|c|c|c|c|c|c|c|}
\hline 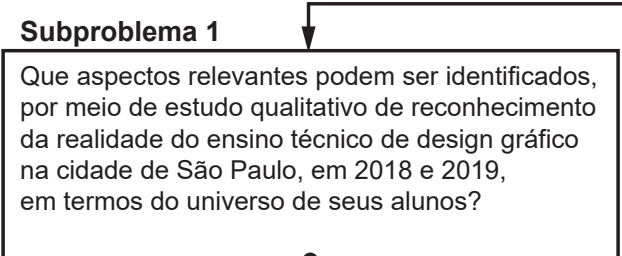 & 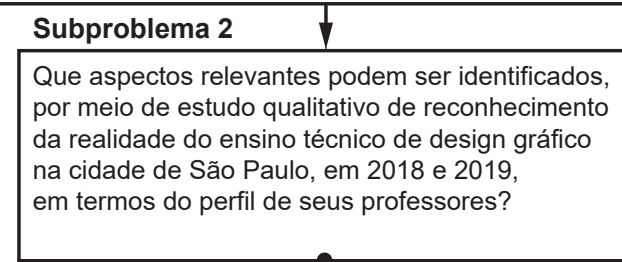 & 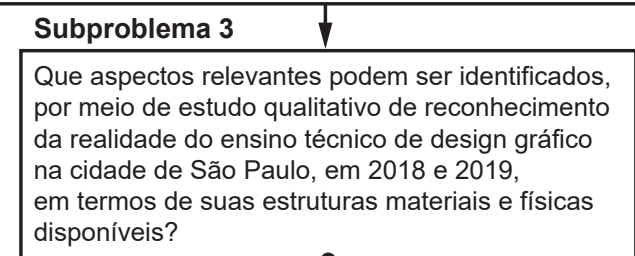 & 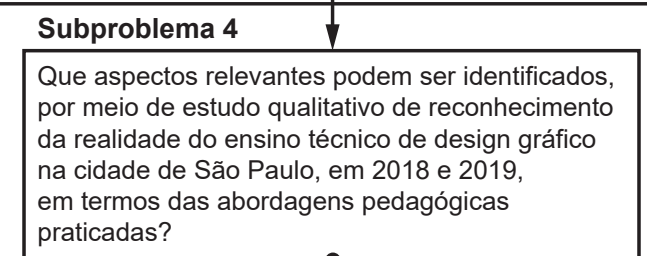 & 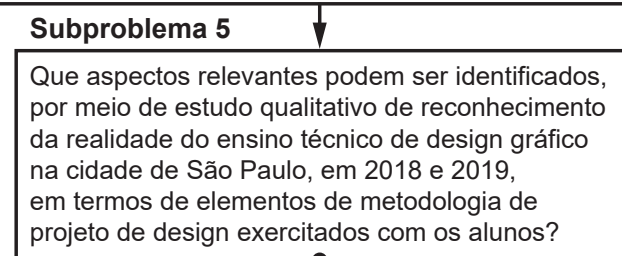 & 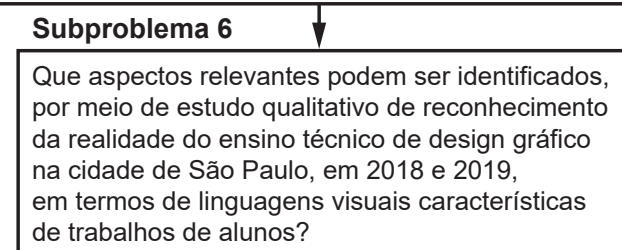 & 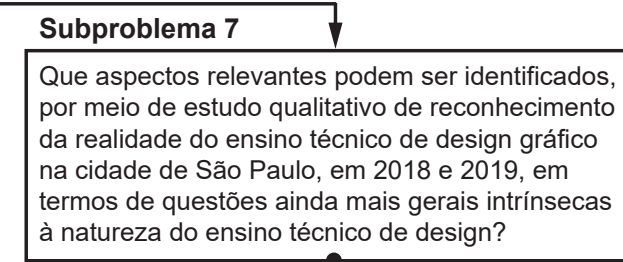 \\
\hline
\end{tabular}

cap. 3 i M̄êtódo

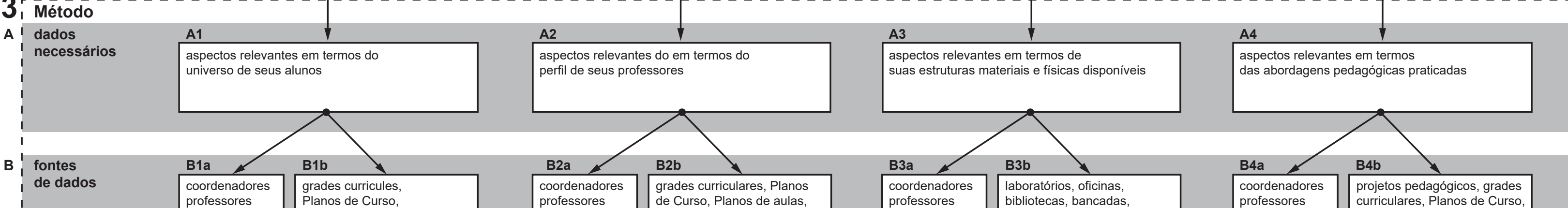

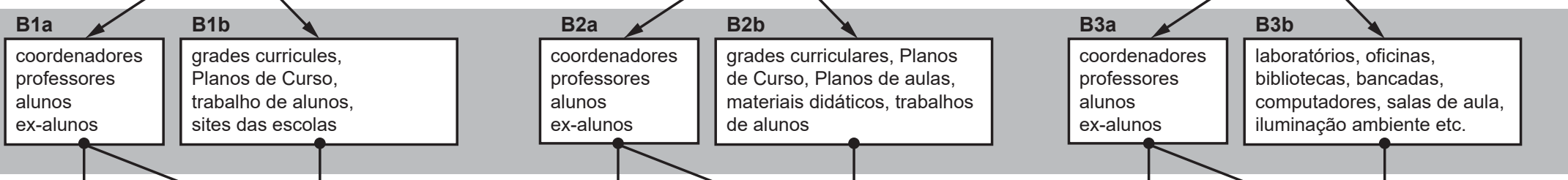

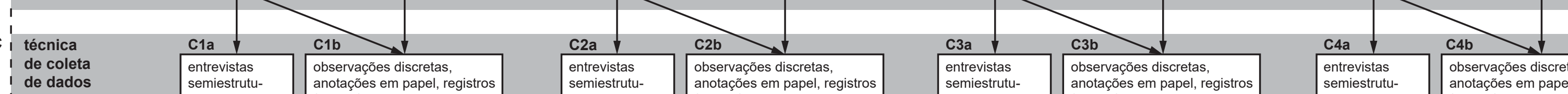

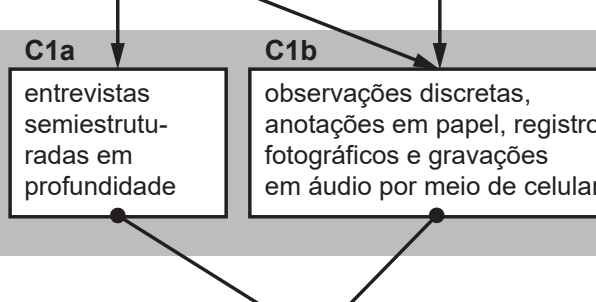

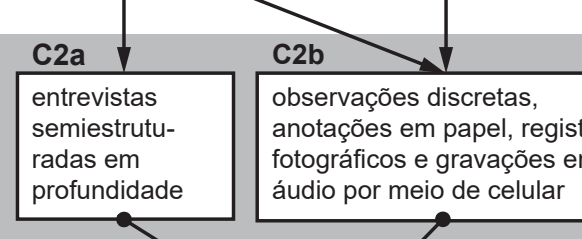

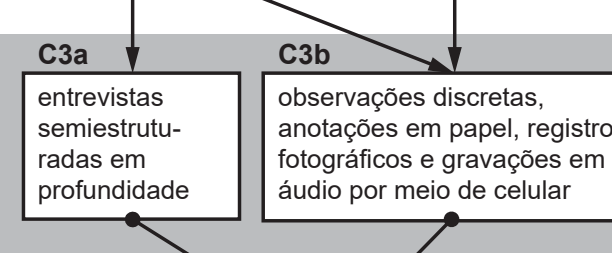
c5a
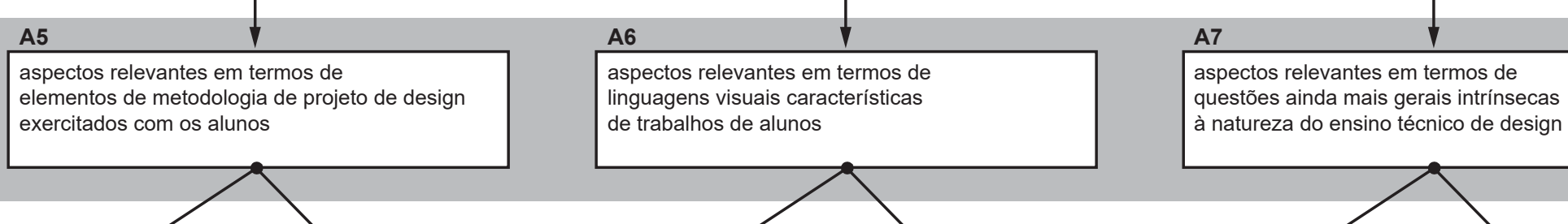

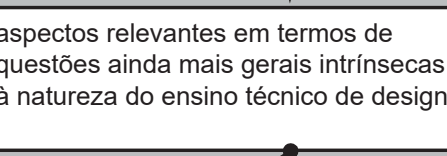

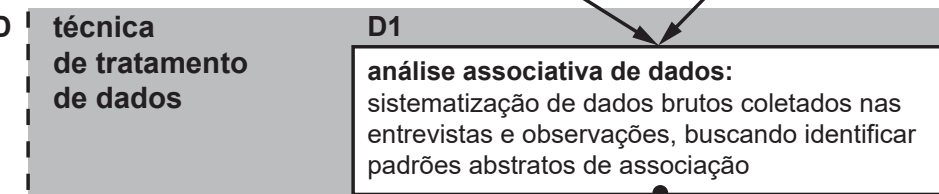

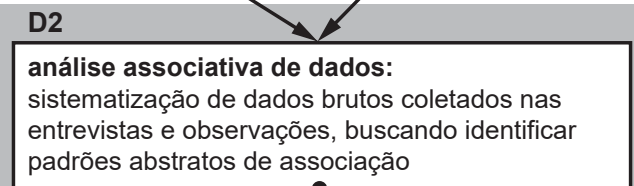

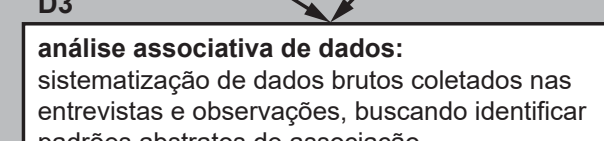
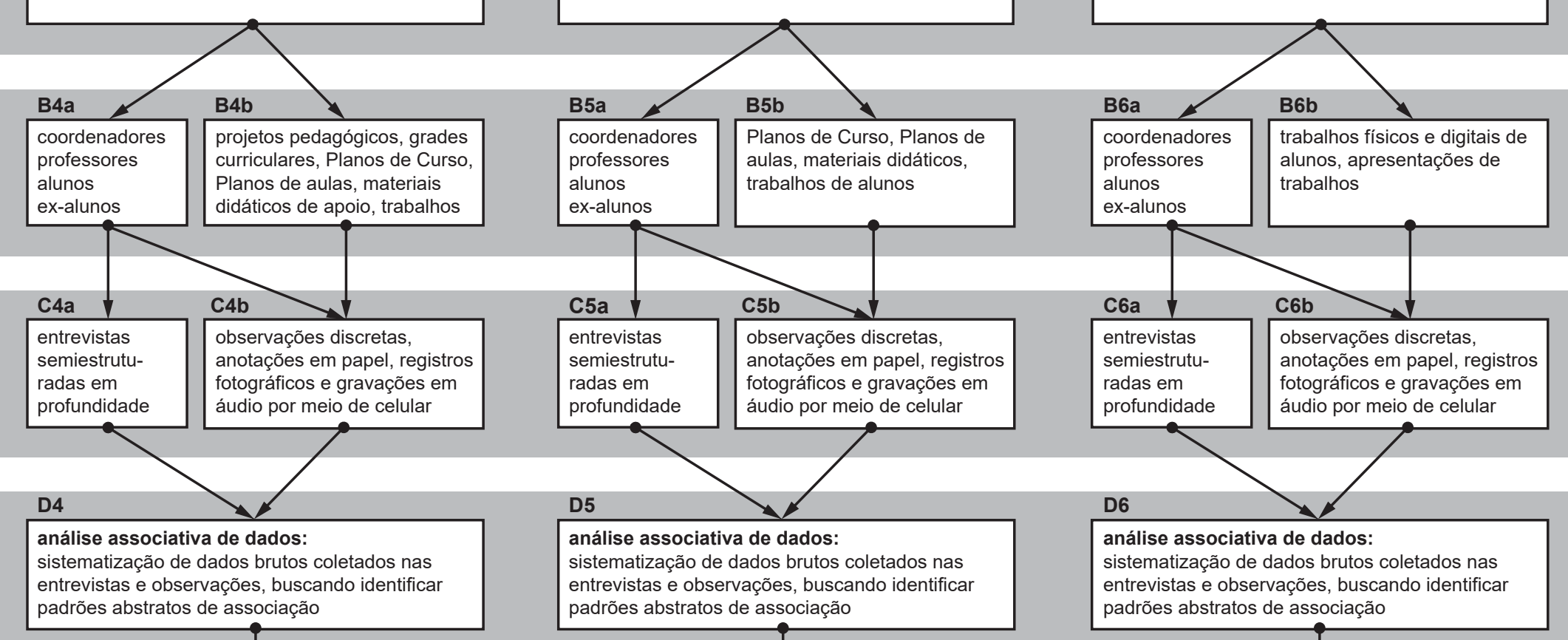

B7b

\section{$E$ \\ cogitados conto
eventualmente
merecedores
de atençäo \\ no exame
do teromeno
estudado

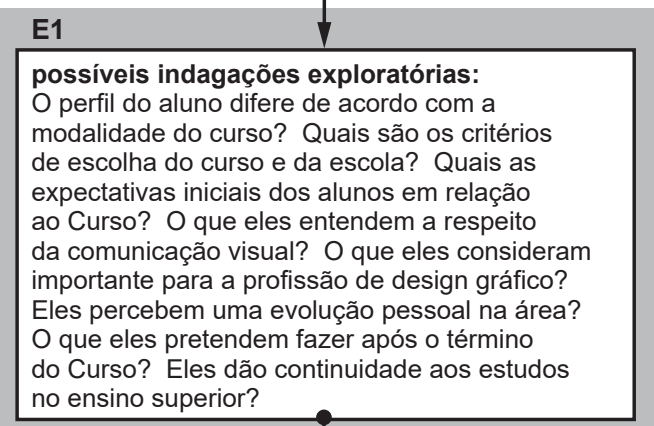

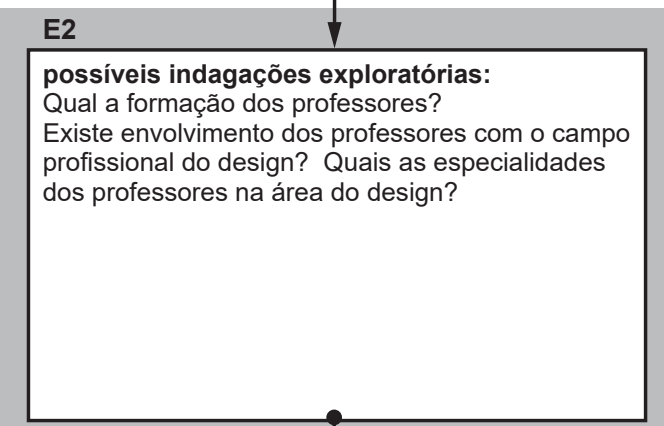

4

relat do dedados analises corressondentes
ao subporbolema 1

cap. 5 i sumário

elatat de dados e analises correspondentes
ao subproblema 2
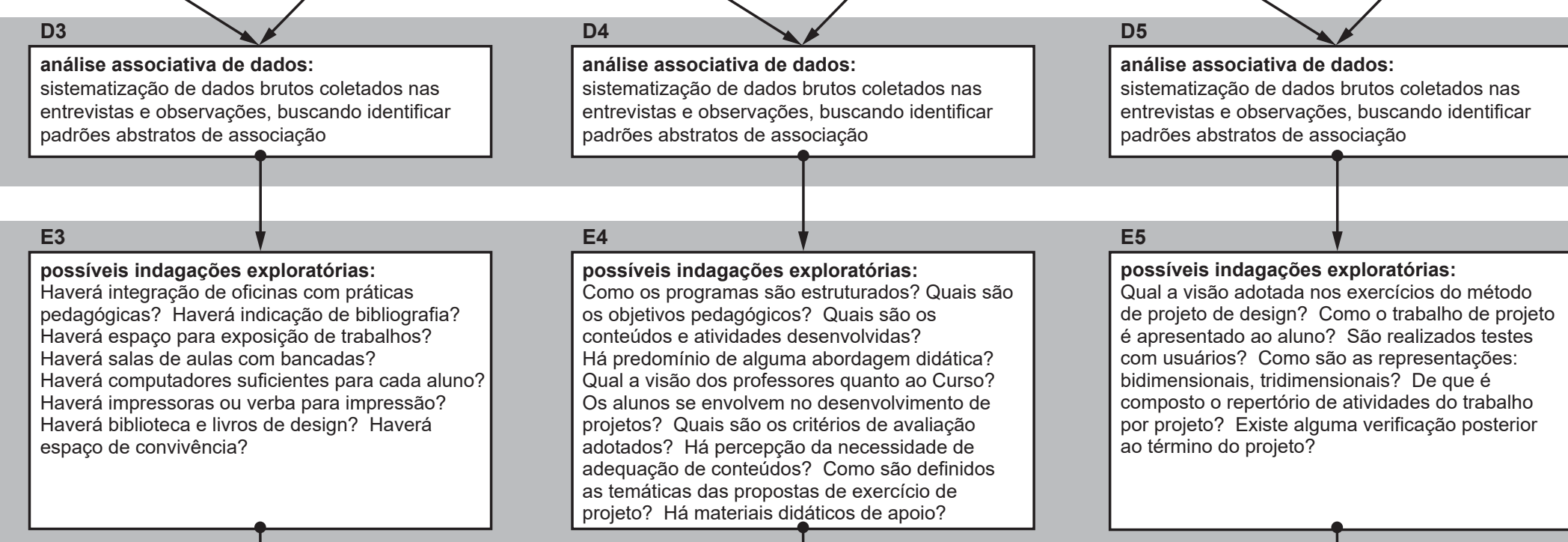

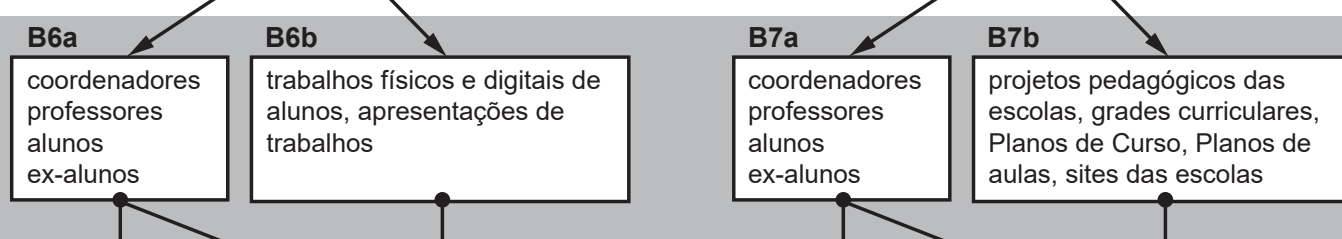
c6b

iconclusões e |

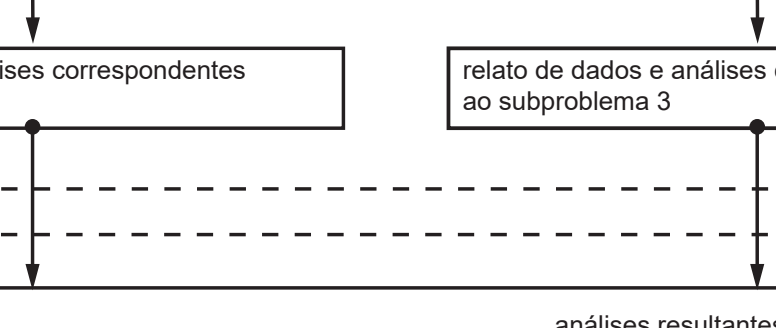

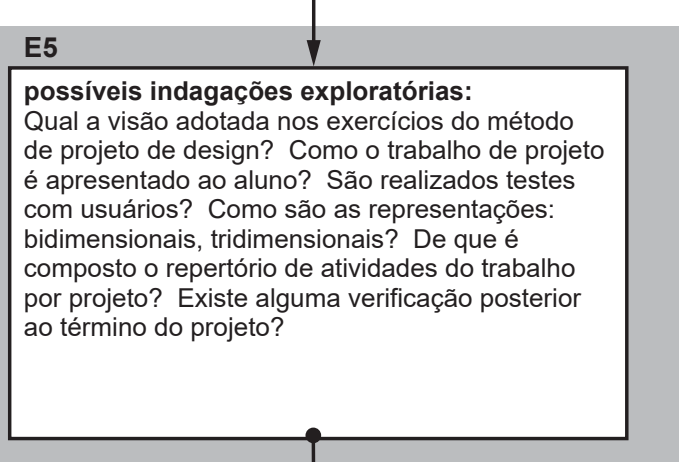

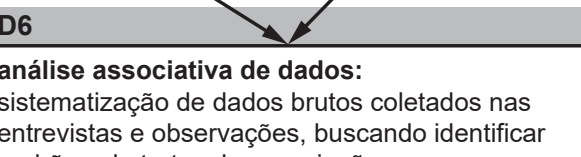

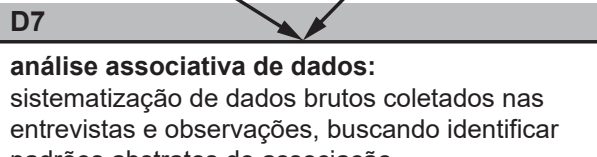

i

cap. 6 il Elementos analises resultantes frnais mais amplas, abrangentes e aprofonndadas, buscando apreender padröes de associaçăo em grau ainda mais abstrato de associagăa 


\subsection{3}

\section{Questão fundamental}

A seguir, apresenta-se a questão fundamental, redigida em seus enunciados sintético e completo, e os subproblemas dela derivados. Para cada um, informou-se os tipos de dados necessários, as fontes de onde esses dados foram obtidos, as técnicas utilizadas para a coleta dos dados, as técnicas para tratamento desses dados e as indagações exploratórias.

\subsubsection{1}

\section{Questão fundamental (em seu enunciado sintético)}

Como se apresenta o quadro atual, em 2018 e 2019, do ensino de design gráfico na cidade de São Paulo?

\subsubsection{2}

\section{Questão fundamental (em seu enunciado completo)}

Que aspectos relevantes podem ser identificados, por meio de estudo qualitativo de reconhecimento da realidade do ensino técnico de design gráfico na cidade de São Paulo, em 2018 e 2019, em termos do universo de seus alunos, do perfil de professores, de estruturas materiais e físicas disponíveis, de abordagens pedagógicas praticadas, de elementos de metodologia de projeto de design exercitados com os alunos, de linguagens visuais características de trabalhos de alunos e de questões ainda mais gerais intrínsecas à natureza do ensino técnico de design, com base em pesquisas de campo realizadas, sobretudo, em duas das dez escolas de ensino técnico de design gráfico em atividade na cidade de São Paulo? 


\section{1}

\section{Aspectos metodológicos do subproblema 1}

\section{(universo dos alunos)}

Que aspectos relevantes podem ser identificados, por meio de estudo qualitativo de reconhecimento da realidade do ensino técnico de design gráfico na cidade de São Paulo, em 2018 e 2019, em termos do universo de seus alunos?

\subsection{1}

\section{Dados necessários à resposta do subproblema 1}

Os dados correspondem aos aspectos do universo de seus alunos relevantes do ensino técnico de design gráfico, quanto a questões, tais como: perfil pessoal dos alunos, segundo relato sobretudo de professores; processos de escolha do Curso técnico em comunicação visual e das escolas; expectativas iniciais dos alunos em relação ao curso técnico; habilidades consideradas relevantes na profissão do design gráfico; percepções sobre a natureza do design gráfico (ou comunicação visual); percebida vocação pessoal para área da comunicação visual; perspectivas profissionais futuras de alunos cursando o ensino técnico; percebida diferença por parte de egressos de cursos técnicos cursando formações universitárias em áreas afins, entre seus colegas de ensino técnico e os de graduação.

\subsection{2}

\section{Fontes para aquisição dos dados do subproblema 1}

As fontes para obtenção destes dados, além da grade curricular, Planos de Curso, sites das escolas, entre outros. Se apoiou, sobretudo, em depoimentos de coordenadores, professores, alunos, ex-alunos.

\subsection{3}

\section{Técnicas adotadas na obtenção das informações do subproblema 1}

As técnicas de coleta de dados adotadas foram as entrevistas semiestruturadas em profundidade aplicadas a agentes que integram as escolas, além de egressos destes cursos, conduzidas, sobretudo, no ambiente escolar. Além disso, realizaram-se observações discretas de aulas. As entrevistas foram anotadas e gravadas em áudio por meio de celular, com conhecimento dos entrevistados 
e posteriormente transcritas. O celular também foi utilizado para registro fotográfico. Para isto, elaborou-se um guia de entrevista, a partir de uma revisão bibliográfica da literatura de design e do ensino técnico, que atuou, também, como um esquema preliminar para a análise das transcrições (BAUER; GASKELL, 2002).

\subsection{4}

\section{Técnicas de tratamento de dados do subproblema 1}

Como anteriormente apontado, após as entrevistas, todos ou áudios foram transcritos integralmente pela pesquisadora. Como técnica de tratamento de dados adotou-se a agregação categórica em uma coleção de exemplos a partir dos dados relativos a aspectos do universo de seus alunos, buscando identificar padrões abstratos de associação relevantes para a questão.

\subsection{5}

\section{Indagações exploratórias referentes ao subproblema 1}

Procurando dar um direcionamento na coleta e tratamento de dados, a partir de aspectos já preliminarmente cogitados como eventualmente merecedores de atenção no exame do fenômeno estudado, utilizou-se de determinadas indagações exploratórias, a saber: O perfil do aluno difere de acordo com a modalidade do curso? Quais são os critérios de escolha do curso e da escola? Quais as expectativas iniciais dos alunos em relação ao Curso? O que eles entendem a respeito da comunicação visual (ou design gráfico)? O que eles consideram importantes para a profissão de design gráfico? Eles percebem uma evolução pessoal na área? O que eles pretendem fazer após o término do Curso? Eles dão continuidade aos estudos no ensino superior? Os egressos de cursos técnicos de comunicação visual, cursando uma faculdade de design ou áreas afins, percebem alguma diferença entre seus colegas que não cursaram o ensino técnico de comunicação visual? 


\section{2}

\section{Aspectos metodológicos do subproblema 2}

\section{(perfil dos professores)}

Que aspectos relevantes podem ser identificados, por meio de estudo qualitativo de reconhecimento da realidade do ensino técnico de design gráfico na cidade de São Paulo, em 2018 e 2019, em termos do perfil de seus professores?

\subsection{1}

\section{Dados necessários à resposta do subproblema 2}

Os dados corresponderam aos aspectos do perfil de seus professores relevantes do ensino técnico de design gráfico, quanto a, por exemplo, formação individual dos professores, perfil dos professores em relação às disciplinas lecionadas, envolvimento dos professores com o design.

\subsection{2}

\section{Fontes para aquisição dos dados do subproblema 2}

Como fontes para aquisição destes dados destacam-se: projeto pedagógico das escolas, grades curriculares, Planos de Curso, Planos de Aula, materiais didáticos, trabalhos de alunos, sites das escolas, bem como depoimentos de coordenadores e professores.

\subsection{3}

\section{Técnicas adotadas na obtenção das informações do subproblema 2}

Assim como para o subproblema 1, as técnicas de coleta de dados adotadas foram as entrevistas semiestruturadas em profundidade aplicadas a agentes que integram as escolas, além de egressos destes cursos, conduzidas, sobretudo, no ambiente escolar. Além disso, realizaram-se observações discretas de aulas. As entrevistas foram anotadas e gravadas em áudio por meio de celular, com conhecimento dos entrevistados e posteriormente transcritas. O celular também foi utilizado para registro fotográfico. Para isto, de acordo com Bauer e Gaskell (2002), elaborou-se um guia de entrevista, a partir de uma revisão bibliográfica da literatura de design e do ensino técnico, que atuou, também, como um esquema preliminar para a análise das transcrições. 


\section{2 .4}

\section{Técnicas de tratamento de dados do subproblema 2}

Como técnica de tratamento de dados, após as transcrições das entrevistas, adotou-se a agregação categórica em uma coleção de exemplos a partir dos dados relativos a aspectos do perfil de seus professores, buscando identificar padrões abstratos de associação relevantes para a questão.

\section{2 .5}

\section{Indagações exploratórias referentes ao subproblema 2}

Procurando dar um direcionamento na coleta e tratamento de dados, a partir de aspectos já preliminarmente cogitados como eventualmente merecedores de atenção no exame do fenômeno estudado, utilizou-se determinadas indagações exploratórias, a saber: Qual a formação dos professores? Existe envolvimento dos professores com o campo profissional do design? Quais as especialidades dos professores na área do design?

\section{3}

\section{Aspectos metodológicos do subproblema 3 (estruturas materiais e físicas)}

Que aspectos relevantes podem ser identificados, por meio de estudo qualitativo de reconhecimento da realidade do ensino técnico de design gráfico na cidade de São Paulo, em 2018 e 2019, em termos de suas estruturas materiais e físicas disponíveis?

\subsection{1}

\section{Dados necessários à resposta do subproblema 3}

Os dados corresponderam aos aspectos das estruturas materiais e físicas relevantes do ensino técnico de design gráfico, quanto a questões, tais como: espaços físicos, laboratórios, oficinas, biblioteca, bancadas, computadores, salas de aula, iluminação ambiente etc. 


\section{3 .2}

\section{Fontes para aquisição dos dados do subproblema 3}

Como fontes para obtenção destes dados destacaram-se, entre outros:

infraestrutura tecnológica das salas e da escola, depoimentos de coordenadores, professores, alunos e ex-alunos, observações da pesquisadora, fotografias dos ambientes escolares.

\subsection{3}

\section{Técnicas adotadas na obtenção das informações do subproblema 3}

As técnicas de coleta de dados se basearam, principalmente, em entrevistas semiestruturadas em profundidade com coordenadores, professores, alunos e ex-alunos; observações dos ambientes e equipamentos das escolas pesquisadas e observações discretas de aulas.

\subsection{4}

\section{Técnicas de tratamento de dados do subproblema 3}

Como técnica de tratamento de dados, após as transcrições das entrevistas, adotou-se a agregação categórica em uma coleção de exemplos a partir dos dados relativos a estruturas materiais e físicas disponíveis, buscando identificar padrões abstratos de associação relevantes para a questão. Valeram-se, ainda, da análise dos registros fotográficos realizados nas escolas.

\subsection{5}

\section{Indagações exploratórias referentes ao subproblema 3}

Procurando dar um direcionamento na coleta e tratamento de dados, a partir de aspectos já preliminarmente cogitados como eventualmente merecedores de atenção no exame do fenômeno estudado, utilizou-se determinadas indagações exploratórias, a saber: Haverá integração de oficinas com práticas pedagógicas? Haverá indicação de bibliografia? Haverá espaço para exposição de trabalhos? Haverá salas de aulas com bancadas? Haverá computadores suficientes para cada aluno? Haverá impressoras ou verba para impressão? Haverá biblioteca e livros de design? Haverá espaço de convivência? 


\section{4}

\section{Aspectos metodológicos do subproblema 4 (abordagens pedagógicas)}

Que aspectos relevantes podem ser identificados, por meio de estudo qualitativo de reconhecimento da realidade do ensino técnico de design gráfico na cidade de São Paulo, em 2018 e 2019, em termos das abordagens pedagógicas praticadas?

\subsection{1}

\section{Dados necessários à resposta do subproblema 4}

Os dados correspondem aos aspectos pedagógicos relevantes do ensino técnico de design gráfico, quanto a questões, tais como: estrutura curricular geral dos programas de escolas técnicas selecionadas (vinculadas e não vinculadas ao ensino médio); aspectos didático-metodológicos; conteúdos, abordagens, propostas e atividades desenvolvidas; grau de motivação verbalizado por alunos e ex-alunos em relação às atividades pedagógicas; experiências pedagógicas percebidas como mais especialmente positivas e menos especialmente positivas por alunos e ex-alunos; percepções comparativas dos alunos sobre práticas de trabalhos individuais e em grupo; filosofias pedagógicas eventualmente fundamentadoras de práticas de ensino; percebido alinhamento entre conteúdos trabalhados e objetivos da formação segundo visão de discentes; eficiência didática dos professores segundo percepção de alunos e ex-alunos; percebida eficiência pedagógica da formação; visão dos professores quanto ao curso técnico em que atuam; processos de avaliação de desempenho dos alunos; percebidas necessidades de adequação de conteúdos segundo ex-alunos; processos de definição das temáticas das propostas dos exercícios de projeto; percebida relação de proporcionalidade entre teoria e prática em atividades pedagógicas; materiais didáticos de apoio.

\section{4 .2}

\section{Fontes para aquisição dos dados do subproblema 4}

Como fontes para obtenção destes dados destacam-se, entre outros: projeto pedagógico das escolas, grades curriculares, Planos de Curso, Planos de Aula, materiais didáticos, trabalhos de alunos, infraestrutura tecnológica das salas, sites das escolas; depoimentos de coordenadores, professores, alunos e ex-alunos. 


\section{4 .3}

\section{Técnicas adotadas na obtenção das informações do subproblema 4}

As técnicas de coleta de dados adotadas foram as entrevistas semiestruturadas em profundidade aplicadas a agentes que integram as escolas, além de egressos destes cursos, conduzidas, sobretudo, no ambiente escolar, bem como observações discretas de aulas. As entrevistas foram anotadas e gravadas em áudio por meio de celular, com conhecimento dos entrevistados e posteriormente transcritas. O celular também foi utilizado para registro fotográfico. Para isto, elaborou-se um guia de entrevista, a partir de uma revisão bibliográfica da literatura de design e do ensino técnico, que atuou, também, como um esquema preliminar para a análise das transcrições.

\subsection{4}

\section{Técnicas de tratamento de dados do subproblema 4}

Como técnica de tratamento de dados, após as transcrições das entrevistas, adotou-se a agregação categórica em uma coleção de exemplos a partir dos dados relativos a aspectos pedagógicos, buscando identificar padrões abstratos de associação relevantes para a questão.

\subsection{5}

\section{Indagações exploratórias referentes ao subproblema 4}

Procurando dar um direcionamento na coleta e tratamento de dados, a partir de aspectos já preliminarmente cogitados como eventualmente merecedores de atenção no exame do fenômeno estudado, utilizou-se determinadas indagações exploratórias, a saber: Como os programas são estruturados? Quais são os objetivos pedagógicos? Quais são os conteúdos e atividades desenvolvidas? Há predomínio de alguma abordagem didática? Os alunos manifestam preferência por trabalhos em grupo ou individual? Quais são as estratégias adotadas para o desenvolvimento de competências? Qual a visão dos professores quanto ao Curso? Os alunos se envolvem no desenvolvimento de projetos? Quais são os critérios de avaliação adotados? Percebe-se propostas mais curtas nos cursos técnicos de design gráfico? Há percepção da necessidade de adequação de conteúdos? Como são definidos as temáticas das propostas de exercício de projeto? Há materiais didáticos de apoio? 


\section{5}

\section{Aspectos metodológicos do subproblema 5 (elementos de metodologia de projeto exercitados)}

Que aspectos relevantes podem ser identificados, por meio de estudo qualitativo de reconhecimento da realidade do ensino técnico de design gráfico na cidade de São Paulo, em 2018 e 2019, em termos de elementos de metodologia de projeto de design exercitados com os alunos?

\subsection{1}

\section{Dados necessários à resposta do subproblema 5}

Os dados necessários correspondem aos aspectos de elementos de metodologia de projeto de design exercitados com os alunos relevantes do ensino técnico de design gráfico quanto, por exemplo, a estrutura metodológica de projeto ensaiada com os alunos e a centralidade eventualmente conferida aos usuários.

\section{5 .2}

\section{Fontes para aquisição dos dados do subproblema 5}

Como fontes para a obtenção destes dados destacam-se, entre outros: trabalhos de alunos, Planos de Curso, Planos de Aula, materiais didáticos e depoimentos de coordenadores, professores, alunos e ex-alunos.

\subsection{3}

\section{Técnicas adotadas na obtenção das informações do subproblema 5}

Adotou-se as entrevistas semiestruturadas em profundidade aplicadas a agentes que integram as escolas, além de egressos destes cursos, conduzidas, sobretudo, no ambiente escolar, bem como observações discretas de aulas. As entrevistas foram anotadas e gravadas em áudio por meio de celular, com conhecimento dos entrevistados e posteriormente transcritas. O celular também foi utilizado para registro fotográfico. Para isto, elaborou-se um guia de entrevista, a partir de uma revisão bibliográfica da literatura de design e do ensino técnico, que atuou, também, como um esquema preliminar para a análise das transcrições. 


\section{5 .4}

\section{Técnicas de tratamento de dados do subproblema 5}

Como técnica de tratamento de dados, após as transcrições das entrevistas, adotou-se a agregação categórica em uma coleção de exemplos a partir dos dados relativos a elementos de metodologia de projeto de design exercitados com os alunos, buscando identificar padrões abstratos de associação relevantes para a questão.

\section{5 .5}

\section{Indagações exploratórias referentes ao subproblema 5}

Procurando dar um direcionamento na coleta e tratamento de dados, a partir de aspectos já preliminarmente cogitados como eventualmente merecedores de atenção no exame do fenômeno estudado, utilizou-se determinadas indagações exploratórias, a saber: Qual a visão adotada nos exercícios do método de projeto de design? Como o trabalho de projeto é apresentado ao aluno? São realizados testes com usuários? Como são as representações: bidimensionais, tridimensionais? De que é composto o repertório de atividades do trabalho por projeto? Existe alguma verificação posterior ao término do projeto?

\section{6}

\section{Aspectos metodológicos do subproblema 6}

(linguagens visuais de trabalhos de alunos)

Que aspectos relevantes podem ser identificados, por meio de estudo qualitativo de reconhecimento da realidade do ensino técnico de design gráfico na cidade de São Paulo, em 2018 e 2019, em termos de linguagens visuais características de trabalhos de alunos?

\subsection{1}

\section{Dados necessários à resposta do subproblema 6}

Os dados necessários correspondem a aspectos relevantes de linguagens visuais características de trabalhos de alunos do ensino técnico de design gráfico, quanto à organização, ritmo, modulação, proporções, padronizações, unidade e diversidade formal, além de sintaxe e semântica presentes nos exercícios desenvolvidos. 


\subsection{2}

\section{Fontes para aquisição dos dados do subproblema 6}

As fontes para a obtenção destes dados circunscreveram-se, basicamente, em trabalhos físicos e digitais de alunos.

\subsection{3}

\section{Técnicas adotadas na obtenção das informações do subproblema 6}

A técnica de coleta de dados baseou-se em fotografar trabalhos de alunos bem como observação discretas de aulas e de apresentações de resultados de trabalhos.

\subsection{4}

\section{Técnicas de tratamento de dados do subproblema 6}

Como técnica de tratamento de dados adotou-se a agregação categórica em uma coleção de exemplos a partir dos dados relativos a aspectos de linguagens visuais características de trabalhos de alunos, buscando identificar padrões abstratos de associação relevantes para a questão.

\subsection{5}

\section{Indagações exploratórias referentes ao subproblema 6}

Procurando dar um direcionamento na coleta e tratamento de dados, a partir de aspectos já preliminarmente cogitados como eventualmente merecedores de atenção no exame do fenômeno estudado, utilizou-se determinadas indagações exploratórias, a saber: Conceitos como unidade e variedade são apresentados aos alunos nas propostas? É evidenciada dificuldade na construção de conceitos de maneira abstrata, como a manipulação de ritmos, cores, escalas e hierarquias? Evidencia-se uma abordagem mais ingênua ou mais sofisticada nos cursos técnicos de design gráfico? Há o emprego e conjugação de linguagens de modo criativo e inovador nos projetos? Aspectos como exatidão das informações, objetividade de sinal, codificação unitária e ausência de ambiguidade são exploradas com os alunos? Percebe-se uma ênfase manual maior nos cursos técnicos de design gráfico? A forma é coesa, tem unidade formal, é modular? O que o design reproduz tem noção de matriz, tem objetividade? A forma é mais funcionalista (evoca utilidade) ou mais estilista (orientada ao "style")? A forma é linguisticamente um trabalho de artes plásticas adaptado para o design? A forma é um trabalho de artesanato adaptado para o design? 


\section{7}

\section{Aspectos metodológicos do subproblema 7}

\section{(questões ainda mais gerais)}

Que aspectos relevantes podem ser identificados, por meio de estudo qualitativo de reconhecimento da realidade do ensino técnico de design gráfico na cidade de São Paulo, em 2018 e 2019, em termos de questões ainda mais gerais intrínsecas à natureza do ensino técnico de design?

\subsection{1}

\section{Dados necessários à resposta do subproblema 7}

Os dados correspondem aos aspectos ainda mais gerais intrínsecos à natureza do ensino técnico de design relevantes do ensino técnico de design gráfico, quanto a questões, tais como: objetivos e ideários do ensino técnico de design gráfico; papel percebido do ensino técnico na atividade profissional do design; relação entre ensino técnico e ensino superior de design gráfico e de áreas afins; eventuais influências relatadas por egressos na escolha posterior de cursos universitários; matizes político-ideológicos eventualmente identificáveis em práticas pedagógicas pesquisadas; antevisões de propostas pedagógicas verbalizadas como ideais.

\subsection{2}

\section{Fontes para aquisição dos dados do subproblema 7}

Como fontes utilizadas para obtenção destes dados destacaram-se: projeto pedagógico das escolas, grades curriculares, Planos de Curso, Planos de Aula, sites das escolas; depoimentos de coordenadores, professores, alunos e ex-alunos.

\subsection{3}

\section{Técnicas adotadas na obtenção das informações do subproblema 7}

Adotou-se as entrevistas semiestruturadas em profundidade aplicadas a agentes que integram as escolas, além de egressos destes cursos, conduzidas, sobretudo, no ambiente escolar, bem como observações discretas de aulas. As entrevistas foram anotadas e gravadas em áudio por meio de celular, com conhecimento dos entrevistados e posteriormente transcritas. O celular também foi utilizado para registro fotográfico. Para isto, elaborou-se um guia de entrevista, a partir 
de uma revisão bibliográfica da literatura de design e do ensino técnico, que atuou, também, como um esquema preliminar para a análise das transcrições.

\subsection{4}

\section{Técnicas de tratamento de dados do subproblema 7}

Como técnica de tratamento de dados adotou-se a agregação categórica em uma coleção de exemplos a partir dos dados relativos a questões ainda mais gerais intrínsecas à natureza do ensino técnico de design, buscando que se emerja significados relevantes para a questão.

\subsection{5}

\section{Indagações exploratórias referentes ao subproblema 7}

Procurando dar um direcionamento na coleta e tratamento de dados, a partir de aspectos já preliminarmente cogitados como eventualmente merecedores de atenção no exame do fenômeno estudado, utilizou-se determinadas indagações exploratórias, a saber: Quais são os objetivos do ensino técnico de design gráfico? Como se dá a integração desses conteúdos e a prática profissional? Como se dá a integração com o ensino universitário? Qual a natureza do ensino técnico de design gráfico em São Paulo? Que particularidades distinguem os cursos técnicos de design gráfico dos cursos universitários da mesma área? Os professores exercem alguma militância ideológica no magistério? Os alunos de ensino técnico de design gráfico dão continuidade aos estudos no ensino superior na mesma área ou em campos próximos?

\section{8}

\section{Cronograma geral do mestrado e da pesquisa}

A seguir, apresenta-se o cronograma geral (quadro 3), abrangendo todo o programa de mestrado e o desenvolvimento da pesquisa e da dissertação, desde seu início, em março de 2018, até a entrega da dissertação de mestrado junto à secretaria de Pós-Graduação, em março de 2020. No cronograma estão dispostos as atividades realizadas, a saber: participações em disciplinas e estágio de docência em matérias da graduação, apresentação em congressos e seminários, bem como os eventos significativos, como o exame de qualificação e o depósito da dissertação. 


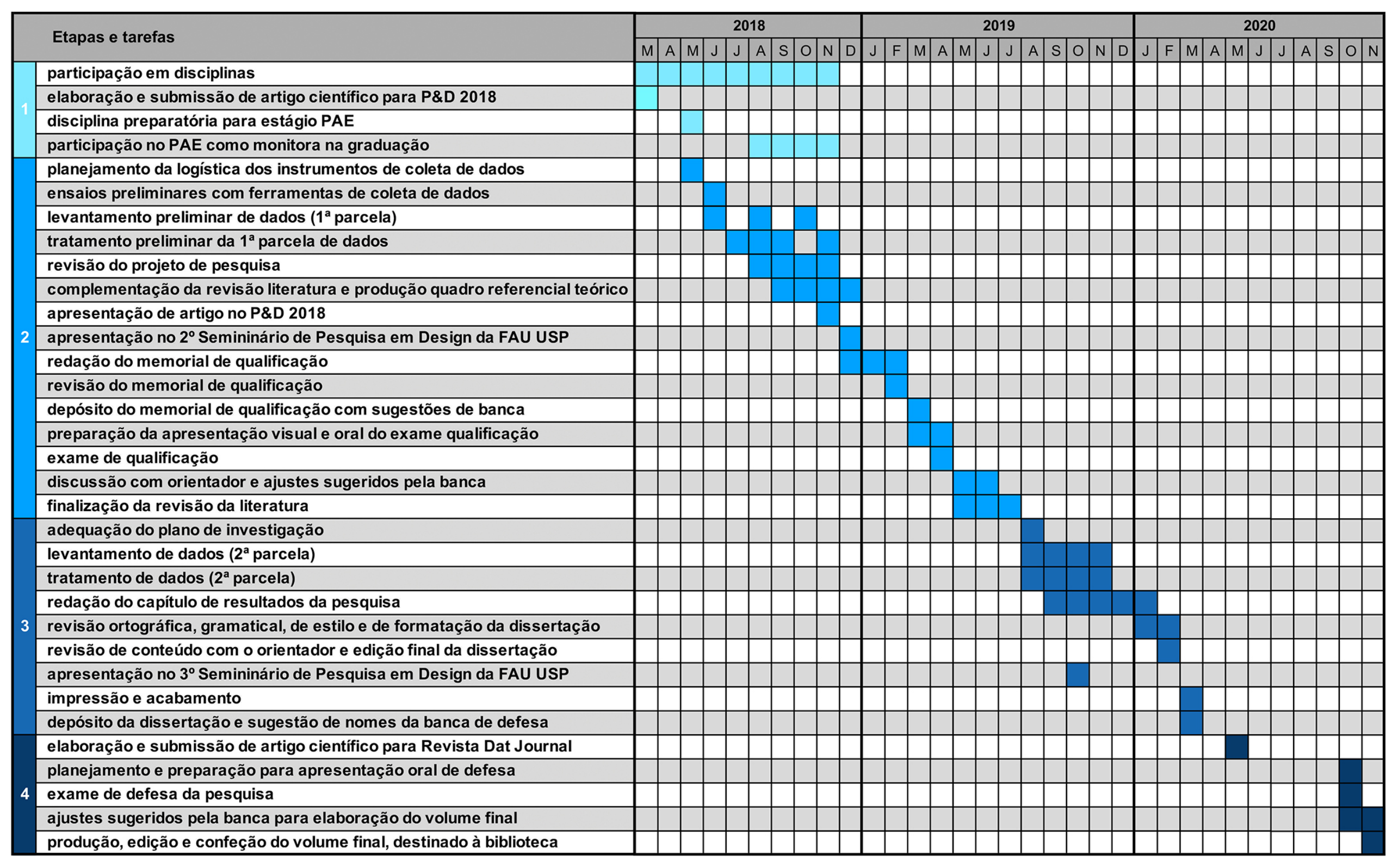




\section{4 \\ Resultados}

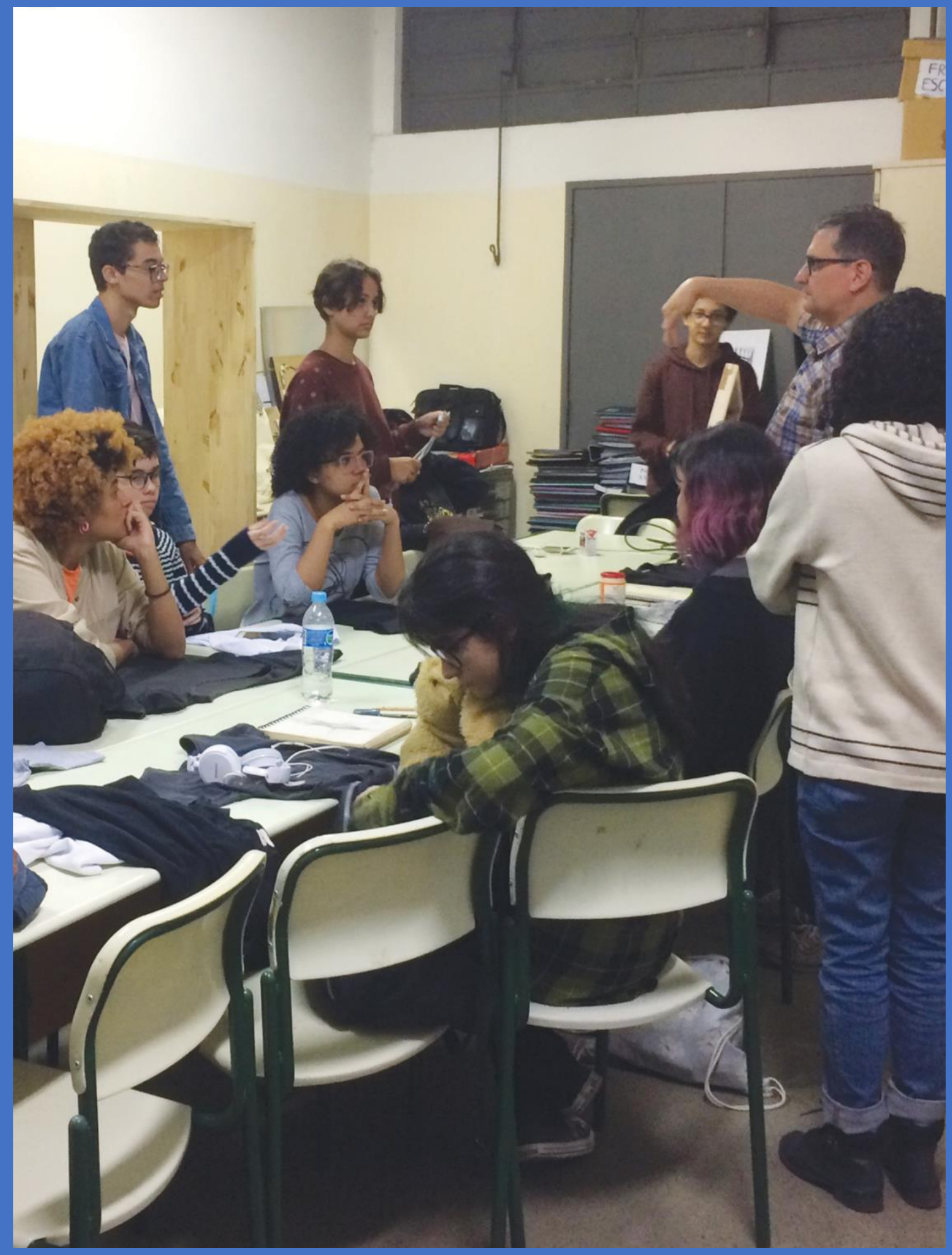




\section{Resultados}

\section{0}

\section{Considerações iniciais sobre os resultados}

Esta pesquisa tem como objeto a pedagogia do design gráfico no ensino técnico na cidade de São Paulo, cuja questão fundamental ocupou-se em identificar, por meio de estudo qualitativo de reconhecimento, aspectos relevantes da realidade do ensino técnico de design gráfico, em 2018 e 2019, sobretudo, em duas das dez escolas em atividade na cidade de São Paulo.

Os sete subproblemas deste estudo são constitutivos da questão fundamental, sendo, em sua maioria, núcleos autônomos, permitindo ser pesquisados separadamente, com o objetivo de simplificar as tarefas de sistematização e análise dos dados necessários à realização desta pesquisa. A definição de cada subproblema se deu pela identificação dos enfoques visando iluminar o problema. Assim, cada subproblema apresenta um determinado aspecto da pedagogia do design gráfico no ensino técnico.

O subproblema 1 apresenta aspectos do universo de seus alunos; o subproblema 2 expõe o perfil de seus professores; o subproblema 3 aponta para as estruturas materiais e físicas disponíveis; o subproblema 4 dispõe as questões relativas a abordagens pedagógicas praticadas, constituindo-se o núcleo mais amplo da pesquisa; o subproblema 5 considera elementos de metodologia de projeto de design exercitados com os alunos, o subproblema 6 apresenta as linguagens visuais características de trabalhos de alunos e, finalmente, o subproblema 7 se ocupa de questões ainda mais gerais intrínsecas à natureza do ensino técnico de design. 
4.1

Resultados concernentes ao subproblema 1

(universo dos alunos)

\subsection{1}

Perfil pessoal dos alunos, segundo relato, sobretudo, de professores

Os dados analisados na categoria temática apresentada nesta seção foram separados em subseções correspondentes às duas principais redes de escolas técnicas cobertas pela pesquisa: a Etec-SP e o Senac-SP.

\subsubsection{1}

Perspectivas de respondentes associados a escolas da rede Etec-SP

Relativo ao perfil pessoal dos alunos, a Respondente 1, professora, percebeu algumas variações. Segundo ela, no Ensino Técnico Integrado ao Médio (Etim), os alunos seriam bastante jovens, com idades variando de 14 a 18 anos, sendo mais imaturos, excessivamente emotivos e possuidores de muita energia. Informou que alguns, no início do curso, apresentariam certa dificuldade em entender a área. Já alunos do ensino técnico não vinculado ao ensino médio do período diurno, o dito modular diurno1, apesar da proximidade de idade com os do Etim (entre 16 e 20 anos), teriam escolhido a formação em busca de ferramentas, de aulas práticas e para montar um portfólio para futuras entrevistas profissionais. Além disto, teriam afinidade com desenho, artes plásticas e, em geral, possuiriam boa visão espacial. Nos dois casos, esta respondente acredita que levariam vantagem em relação a alunos egressos do ensino médio tradicional ao chegarem ao ensino superior, por já possuírem as ferramentas e conhecerem a área.

Quanto aos do dito modular noturno, mencionou que o perfil seria muito heterogêneo, com idades entre 25 a 35 anos, em média, sendo poucos do ensino médio. Acredita que cerca de $30 \%$ já seria do ramo e que o restante escolhera o curso

\footnotetext{
1 O Curso Técnico em Comunicação Visual (não vinculado ao do ensino médio) será designado
} "modular diurno" ou "modular noturno". 
por já possuir alguma habilidade na área e querer mudar de profissão ou, ainda, para fazer um resgate. Em comum, todos demonstrariam bastante interesse.

De modo complementar, a Respondente 7, professora, responsável pela disciplina "Aplicativos Informatizados em Design Gráfico I e II", mencionou que alunos do Etim seriam extremamente entusiasmados, interessados e deslumbrados com a ideia do design. Declarou que, em geral, já chegariam com noção do que seria a disciplina, tendo pesquisado anteriormente. Acrescentou que demonstrariam facilidade, aprendendo de forma natural. Já alunos do modular noturno, além de mais velhos, alguns se interessariam somente pela prática, não considerando a importância da parte teórica para sua formação, apenas mirando uma possível inserção no mercado de trabalho.

Assim como a Respondente 1, a Respondente 3, também professora, informou perceber grande variedade entre os alunos. Segundo ela, "Tem tudo o que você possa imaginar", pois, à noite, receberiam alguns alunos já formados em áreas correlatas, como professores de história da arte, mas também profissionais oriundos de outros campos, tais como sociólogos, engenheiros, professores de educação física, entre outros; além disto: "Tem aluno que entra aqui sem noção nenhuma de nada". Em contrapartida, o Respondente 2, igualmente professor, também afirmou ser um perfil bem diversificado e que chegariam ansiosos, identificando um equilíbrio quanto ao gênero. Relatou que grande número de meninas, na época da implantação do computador na escola, demonstraria resistência em utilizá-lo, mas se adaptara à linguagem digital. No caso de alunos do modular noturno, alguns já teriam feito curso superior em outra área, enquanto outros procurariam o curso para se atualizar. Declarou, ainda, que boa parte já ingressaria com repertório, sendo pessoas literalmente de Humanas e "[...] entendem que a arte é o conector para melhor compreender as relações da produção visual". Isto talvez esteja associado a uma visão mais pessoal deste respondente, uma vez que a sofisticação desta construção não parece exatamente corresponder ao grau de maturidade característica de alunos neste estágio do curso.

Ainda, relativamente ao perfil dos alunos, o Respondente 4, também professor, declarou que a anterior denominação do curso, "Técnico em Design Gráfico", atrairia 
um público mais centrado, "[...] que sabia mais ou menos o que queria", com perfil mais relacionado ao design. Ao trocar de nome o curso, mudara o público, porque eles passaram a associá-lo com a comunicação em geral: "Não tem tanto design. Lembra muito mais um curso de propaganda". De modo análogo, o Respondente 5, outro professor, também consideraria crítica a denominação do curso: "O cara se inscreve p'ra comunicação visual e, talvez, este nome seja um pouco vago, não defina, com clareza, do que se trata. A pessoa imagina que seja um curso de Belas Artes". Para ele, isto ocasionaria, algumas vezes, problemas de evasão. E completa: "[...] embora tenha a ementa disponível, é muito raro quem se atente a ver aquilo com cuidado". Isto sugere que o nome do curso, "Técnico em Comunicação Visual", não corresponderia realmente ao que estaria sendo ofertado. Pressupõe, ainda, que muitos alunos ingressariam no curso sem prévia pesquisa a respeito de seu conteúdo.

Por outro viés, o Respondente 4, também professor, informou a presença de todas as classes sociais, com predomínio da dita classe média baixa e baixa. Nos períodos da manhã e da tarde, grande número seria composto de estudantes e, à noite, de alunos trabalhadores, segundo ele, um perfil muito delicado, por já chegarem à escola fadigados da jornada do dia. De modo semelhante, o Respondente 6 , outro professor, relatou que, de modo geral, o pessoal da tarde seria mais jovem e mais produtivo que o da noite, por disporem de mais tempo para se dedicar: "Às vezes, você percebe que o aluno [da noite] tem potencial, mas não consegue fazer o trabalho devidamente porque tem que conciliar com o trabalho". Acrescentou que, à tarde, grande parte cursaria ensino médio pela manhã; outra parte o finalizara pouco tempo antes, não necessitando trabalhar de imediato por ainda morar com a família.

O mesmo Respondente 4 apontou o perfil dos alunos como sendo da área criativa. Para ele, "Tem uma certa fala, mas é um pouco reprimido, se representa muito mais visualmente, mas em geral, é mais quieto, muito introspectivo". Mencionou, como problemática, a escolha tendo sido determinada por imposição do pai (que o obrigara a fazer algum curso técnico): "[...] e esse talvez fosse o curso mais fácil, por causa das disciplinas plásticas, disciplinas do computador [...] e ele acaba vendo que não é muito o que queria". Isto sugere que, em alguns casos, o curso não atenderia as expectativas do aluno, acarretando sua desistência. 
De maneira complementar, o Respondente 6, também professor, mencionou presença de dois perfis principais: os que realmente teriam interesse, vocação, gosto pela parte artística, design, comunicação visual e aqueles que estariam procurando se encontrar: "Às vezes, ele gosta de algo visual, de grafite, [...] procura exposições, curte muito desenho animado, animé, mangá, tem interesse em desenho e, por isso, procurou o curso". Esta declaração sugere que parte dos alunos ingressaria no curso por apresentar afinidade com a área criativa, porém, parece que poucos possuiriam exato conhecimento do que seria a área do design.

Os dados comentados nesta categoria relacionada ao perfil dos alunos de cursos de comunicação visual de escolas técnicas da rede Etec parecem indicar que este universo discente seria bastante diversificado. Tal variação estaria associada a diferentes origens e formações, modalidade do curso, maturidade em função da idade, momento de vida, anterior afinidade com a área, entre outros.

\subsubsection{2}

\section{Perspectivas de respondentes associados a escolas da rede Senac-SP}

A Respondente 29, professora, informou que o requisito mínimo para cursar o ensino técnico de comunicação visual no Senac-SP seria estar no $2^{\circ}$ ano do ensino médio e/ou ter 16 anos, sendo a média de idade de 25 anos. Quanto ao momento de vida, em geral, já haveriam finalizado o ensino médio. Além disto, mencionou perceber diferença de motivação em relação ao curso. De acordo com ela: "Muita gente vem de áreas diferentes, quer mudar de área ou se aprimorar, mas não quer investir tanto tempo e dinheiro numa faculdade. Ou, como o curso é dividido em quatro qualificações técnicas, cada um pode se especializar numa área diferente".

Tal afirmação parece indicar que o perfil do aluno seria bastante diversificado, que o fator tempo, percebido como mais restrito, teria muita relevância e que a possibilidade de cursar uma qualificação técnica específica possibilitaria escolha mais relacionada ao universo pessoal do aluno.

De modo complementar, a Respondente 30, também professora, informou que o perfil do aluno estaria diretamente relacionado ao objetivo do curso. Segundo ela, 
"O curso objetiva formar profissionais. [...] Nós ensinamos p'ra que o cara seja contratado em algum lugar e assuma que é um assistente de arte, que é um designer". Além disto, informou que nem todos os alunos seriam destinados ao mercado de trabalho especificamente de design, exemplificando: "Eu já tive aluno formado em marketing, que fez apenas a 'Qualificação 1'2. [...] Vem gente mesmo p'ra sentir, p'ra ter repertório, argumentar. Esses são os que ficam na média. São atendidos na 'Qualificação', mas não vão além”. Esta visão sugere que alunos fazendo o curso, sem apresentarem um propósito maior em relação a possível posicionamento no mercado de trabalho, manteriam uma atitude, em certa medida, pouco comprometida com relação ao próprio aprendizado.

Quanto à sua postura frente ao aluno, a mesma Respondente 30 informou: "O aluno interessado, eu marco exposição e eu vou junto, indico todos os cursos possíveis, bolsa de estudo, mando material, vaga de estágio e reverbera p'ra todo mundo". Sua fala sugere que os alunos percebidos como mais predispostos a aprender estimularia, ainda mais, o viés colaborativo da docente, possibilitando, em cadeia, motivar outros colegas. A respeito do observado desinteresse ou desatenção de determinados alunos, relatou: "Tem aqueles que 'tão lá, não vêm, não perguntam, nunca têm dúvida. O que 'tá afogando, eu tiro, faço boca a boca e o que 'tá voando muito alto, eu puxo um pouquinho também. No que a gente percebeu, temos mais os virtuosos, graças a Deus!". Tal relato parece denotar comprometimento da professora em estimular e mesmo resgatar os menos focados. Além disto, parece sugerir satisfação dos docentes com o empenho geral discente.

De maneira complementar, o Respondente 31, outro professor, citou que haveria alunos muito motivados a seguir carreira profissional em design ou em áreas afins: "Recebo aluno com bastante repertório, com interesse em trabalhar em agências ou escritórios de design. Alguns pretendem montar seu próprio negócio. Os que caem de paraquedas são poucos". Esta passagem parece indicar que haveria, de modo geral, comprometimento do aluno tanto para cursar como para seguir a área do design. O mesmo Respondente 31 também informou presença de um tipo específico de aluno: "Tem aluno já graduado em design. Vem aprender a prática

${ }^{2}$ Qualificação Profissional Técnica de Assistente de Arte. 
de criação. Sabe como funciona um offset, entende o processo criativo, mas não consegue aplicar na prática, criar a partir de um briefing, pedir um orçamento, mexer em software gráfico". Uma possível explicação para esta afirmação seria a existência de faculdades de design que não estariam formando adequadamente um profissional e, em certos casos, cursos técnicos estariam cobrindo tal lacuna.

Já a Respondente 32, outra professora, quanto ao período de realização das aulas, afirmou notar diferença entre o pessoal da tarde e o da noite: "[...] não por interesse, mas por cansaço e demandas, esgotamento. Quando esse cansaço é muito latente, muito pesado, o aproveitamento é outro", o que corrobora a visão da citada Respondente 29. Segundo ela, "À noite, é um perfil que já trabalha, então, eles já vêm cansados. À tarde é bem difícil alguém 'tá trabalhando, quando 'tá, é freelancer. Mas o perfil da turma da tarde é bem diferente. É mais empenhado". Estes relatos parecem indicar que a jornada de trabalho dos alunos do período noturno comprometeria, em certa medida, o rendimento geral, evidenciando maior envolvimento da turma da tarde nas atividades propostas.

Por outro ponto de vista, a Respondente 30, professora já mencionada, relatou a importância de estar constantemente se adaptando. Para ela, "[...] o seu repertório discente é efêmero, ele muda o tempo todo porque, cada dia, eles estão de outra maneira. Então, se você não tiver uma metodologia ativa, que ampare, por exemplo, o celular como uma ferramenta, você não consegue trabalhar". Uma possível explicação para esta afirmação é o fato de que mudanças em vários aspectos da vida cotidiana estariam refletindo na postura dos alunos em relação ao próprio aprendizado, demandando flexibilização do ensino para acompanhar tais demandas.

De maneira complementar, a Respondente 32 informou a relevância de se estar atento a alterações comportamentais dos alunos: "Eu percebo uma atitude muito diferente dessa geração [...]. Eles entendem mais seus direitos e estão mais sentidos com as coisas, muitos problemas psicológicos. [...] O interesse vem aumentando porque as oportunidades estão minguando". Com base em seu depoimento, parece que essa geração de alunos, talvez por conta de maior facilidade de acesso a informações possibilitadas pela internet, apresentaria atitude mais responsável em relação ao próprio aprendizado. 
Com base nos dados analisados nesta categoria concernente ao perfil dos alunos do curso de comunicação visual de escolas técnicas da rede Senac-SP, este universo discente seria bastante diversificado, sendo composto por alunos de diferentes formações e origens, grande parte deles já tendo concluído o ensino médio.

Os alunos do horário noturno, em função da jornada diurna de trabalho, tenderiam a apresentar, de modo geral, conforme depoimentos, rendimento menor em relação aos alunos do turno diurno. A possibilidade de cursar uma qualificação técnica apenas em determinadas disciplinas específicas (uma espécie de fatiamento do curso integral de comunicação visual) estimularia a formação de outra classe de alunos: aqueles que buscam uma qualificação técnica específica. Além disso, alunos percebidos por seus professores como mais determinados a ingressar no mercado profissional de comunicação visual tenderiam a apresentar rendimento superior nas disciplinas cursadas.

\subsection{2}

\section{Processos de escolha do curso técnico de comunicação visual e das escolas}

Os dados analisados na categoria temática apresentada nesta seção foram separados em subseções correspondentes às duas principais redes de escolas técnicas cobertas pela pesquisa: a Etec-SP e o Senac-SP.

\subsubsection{1}

\section{Perspectivas de respondentes associados a escolas da rede Etec-SP}

Em relação ao processo de escolha do curso, o Respondente 17, aluno do Etim, declarou haver se definido pela área da comunicação visual pensando mais em artes, especificamente em grafite. De acordo com ele, "Vim mais pela parte de artes, porque minha mãe fazia técnico de cozinha na [Etec] Carlos de Campos. Aí, o pessoal de 'CV'3 ficava fazendo grafite no muro. Ela falou: vai lá, eles fazem grafite, você deve ir, deve ser bacana ter essa parte de arte". Observe-se que este respondente teria

\footnotetext{
${ }^{3}$ CV: Técnico em Comunicação Visual
} 
escolhido o curso pensando em "fazer grafite". Isto sugere ausência de conhecimento a respeito da real natureza da comunicação visual. Sugere, ainda, que haveria certa influência de sua mãe na escolha do curso.

A Respondente 20, outra aluna do Etim, mencionou que optou pelo Curso Técnico em Comunicação Visual por gostar de desenhar: "Eu só vim p’ra cá, inclusive, porque eu tinha uma outra amiga que queria fazer moda. E, como eu sempre gostei de desenhar, eu imaginei: comunicação visual. Aí, eu olhei a grade e falei: legal, desenhos". De modo similar, a Respondente 25, uma ex-aluna da modalidade não integrada ao ensino médio informou sua anterior afinidade por desenho. Segundo ela, "Eu quis fazer técnico porque eu sempre gostei de desenhar, mas não queria ser desenhista. [...] Na época, a percepção era de que, p'ra ter um emprego ou entrar numa faculdade, um curso técnico poderia ajudar". Note-se que o curso técnico seria percebido como uma possibilidade de se preparar para o mercado de trabalho ou para servir de ponte para o ensino superior. Isto sugere intenção desta respondente em procurar o ensino técnico pensando em definir sua futura área de atuação profissional. Pressupõe, também, que a escolha seria baseada na sua convicção pessoal de que comunicação visual teria alguma relação com desenho.

Quanto à definição da instituição, a mesma Respondente 25 declarou possuir vivência anterior na escola. Para ela, "Já conhecia a Etec, porque fiz ensino médio na cidade onde moro. Escolhi o 'KK'4 porque era a Etec mais perto da minha casa, só pegava uma linha de trem". Observe-se que esta respondente morava em outra cidade e haveria uma estação ferroviária próxima à escola. Isto sugere que a escolha aconteceria em função de facilidade de acesso e não, necessariamente, por reconhecimento da qualidade do ensino dessa unidade escolar.

Já a Respondente 23, também ex-aluna, relatando seu próprio processo, informou que comunicação visual não teria sido sua escolha inicial: "Eu fui fazer ensino técnico p'ra saber o que eu queria fazer da vida. Aí, eu fiz o técnico p'ra experimentar um pouquinho, p'ra saber [...]. Tanto, que eu fiz design de interiores. Hum, não é o que eu quero, vou p'ra design mesmo". Esta passagem sugere que o ensino técnico

\footnotetext{
${ }^{4}$ KK: sigla informal utilizada para significar a Etec Carlos de Campos
} 
teria auxiliado esta respondente a definir sua área profissional. Ainda, a respeito da definição da escola a ser cursada, informou anterior conhecimento: "Eu escolhi o 'KK' porque minhas amigas já tinham tido aula lá e eu sabia como era o ambiente. [...] Uma pena é que era no meio do Brás porque, quando chovia, a rua alagava". Note-se que apesar de certa dificuldade de acesso em dias de chuva e da distância de sua residência, esta respondente teria escolhido estudar nessa escola. Isto parece indicar que o ensino dessa instituição seria reconhecido como de qualidade.

Por seu turno, a Respondente 19, também aluna do Etim, ao relatar sua escolha, informou já ter entrado pensando em pintura: "Eu entrei porque eu sabia que a gente ia fazer um quadro e eu fiquei interessada nessa parte. [...] Professor meu que me indicou". Esta declaração pressupõe que conteúdos mais característicos do universo das artes plásticas, como exercícios de pintura, fariam parte da grade curricular do Curso Técnico em Comunicação Visual. Revela, ainda, que a indicação de determinado professor teria tido grande influência na sua escolha.

De modo diverso, a Respondente 15, aluna do terceiro módulo do curso noturno não vinculado ao ensino médio, declarou que gostar de estudar teria sido o motivo da escolha por cursar o Técnico em Comunicação Visual. De acordo com ela: "Acabei DI [Técnico em Design de Interiores] e entrei direto p'ra CV [Técnico em Comunicação Visual] p'ra dar um prosseguimento, uma continuação, querendo coisa nova". Em relação a seus colegas, mencionou acreditar que: "[...] cada um entra querendo melhorar uma área", acrescentando estar, naquele momento, mais bem preparada: "Meu olhar já mudou com o curso. Você já começa a olhar as coisas de modo diferente". Note-se que esta respondente haveria concluído, imediatamente antes, o curso Técnico em Design de Interiores e decidira cursar o Técnico em Comunicação Visual. Isto sugere que os cursos técnicos desta instituição seriam percebidos como relevantes e que esta aluna, em especial, seria bastante motivada por aprender. Pressupõe, também, que vários alunos teriam escolhido o Curso pensando em se aprimorar em determinado segmento da área de comunicação visual.

Por sua vez, a Respondente 24, outra ex-aluna, informou ser de outra cidade e sempre ter ido longe para chegar à escola. Quanto a seu processo de escolha, aos 15 anos de idade, mencionou apresentar anterior afinidade em manipular 
imagens. Segundo ela, "Sempre manuseei programa de imagem no computador, desde pequena tinha blog. Era das exatas no ensino médio e, na hora de prestar, fiquei em dúvida entre design de interiores, administração e contabilidade, mas resolvi prestar comunicação visual". Esta passagem sugere dificuldade dessa respondente em determinar a área de estudo, possivelmente por ser ainda tão nova. Pressupõe, ainda, que o fato de já gostar de editar imagens teria motivado sua escolha por comunicação visual. Em relação à definição pela escola, a própria Respondente 24 declarou: "Eu caí na Etec por acaso, nem conhecia ninguém que estudava lá. Fiquei empolgada porque tinha armário lá, tipo escola americana. Fazia de manhã ensino médio e à tarde ensino técnico. [...] Era muito puxado, mais que a faculdade, no começo". Esta fala denota não haver tido influência de amigos na escolha por cursar a Etec. Sugere, ainda, que esta respondente, em particular, teria força de vontade ao fazer o ensino técnico junto com o médio, mesmo morando em outra cidade.

Em contrapartida, o Respondente 26, outro ex-aluno, também haveria feito o ensino técnico concomitantemente ao ensino médio. Relatando seu processo de escolha pela Etec, mencionou que, desde muito cedo, já teria ideia de qual carreira seguir. Segundo ele, "Eu escolhi ir p'r'o ensino médio do 'KK' por conta do curso de design de interiores porque, desde os 12, 13 anos, eu queria ser arquiteto. Eu tinha amigos mais velhos que faziam comunicação visual e eu comecei [...] a achar muito legal o que eles faziam". Note-se que este respondente haveria escolhido cursar o ensino médio na Etec, já pensando em ingressar, posteriormente, no Técnico em Design de Interiores, na mesma Etec, em razão de anterior afinidade por arquitetura, apesar disso, teria optado pelo Técnico em Comunicação Visual. Isto sugere que os trabalhos desenvolvidos nesse curso seriam percebidos como relevantes, a ponto de uma pessoa, supostamente decidida, mudar a área de estudo.

O Respondente 21, igualmente aluno do Etim, ao se informar sobre o curso, optara por comunicação visual buscando aprender programas gráficos. De acordo com ele, "Quando eu pesquisei sobre o curso e fiz a inscrição, eu pensei que boa parte do curso seria toda no computador e que a gente ia aprender a fazer algumas coisas que a gente não aprende. Por exemplo, mexer com Java”. Este trecho do seu depoimento sugere que, apesar de este aluno ter pesquisado a grade do curso antes 
de definir a área, conteúdos específicos de programas gráficos não teriam correspondido à sua ideia inicial.

Similarmente, quanto a seu processo de escolha, a Respondente 27, uma ex-aluna do Etim, informou desejo de aprender programas gráficos, mas com um propósito mais definido. Segundo ela, "Eu achava que comunicação visual podia me adiantar esse lado, ter um conhecimento prévio do que seria a publicidade, agregar algumas habilidades. Mexer nos programas, que seria útil, com certeza, p'ra publicidade. 'Tê' um repertório básico". Sua fala sugere possível familiaridade entre conteúdos do Curso Técnico em Comunicação Visual com a área da publicidade e propaganda. Ainda a este respeito, a mesma Respondente 27 informou que não haveria muita opção: "Na minha Etec, só tinha administração, eletrônica, moda e comunicação visual. [...] Tinham várias pessoas que escolhiam por matérias específicas. [...] Eu não sabia nem quais matérias tinham. Eu fui mais pelo conteúdo do curso". Esta passagem parece indicar que parte dos alunos não pesquisaria as disciplinas oferecidas antes de definir a área a ser cursada.

Em relação à instituição, a mesma Respondente 27 comentou que teria sido uma grande mudança. De acordo com ela, "Eu estudava no Sesi. Minha mãe perguntou se eu queria ir p'ra Etec. Eu ia ter que abdicar de muitas coisas. Na época, eu tinha 14 anos. [...] O Sesi é mais uma bolhinha e ir p'ra Etec me fez crescer muito". Este segmento parece indicar que haveria certa influência de sua mãe na escolha da escola, possivelmente por conta de sua pouca idade. Sugere, ainda, que essa escola teria promovido seu amadurecimento.

Já o interesse do Respondente 22, também aluno do Etim, seria em comunicação, não a visual: "[...] minha mãe queria que eu fizesse técnico. [...] Aí, eu fui escolher um curso e vi comunicação visual. P'ra ser sincero, eu nem olhei direito p'r'o visual, eu vi só comunicação. Aí, eu falei: 'Nossa, gosto muito de me comunicar'”. Sua declaração sugere que a denominação do curso "Comunicação Visual” teria influenciado, em certa medida, suas suposições acerca das reais atribuições da área. Sugere, ainda, como no caso da Respondente 27, ausência de pesquisa prévia a respeito de conteúdos e/ou disciplinas no processo de escolha do curso. 
A Respondente 28, outra ex-aluna do Etim, informando a vantagem dessa modalidade de técnico, mencionou que: "Gostei de ter feito Etim porque a distribuição do curso foi bem mais confortável dessa maneira, deu p'ra viver bem. [...] Também pelo fluxo das aulas, porque a gente 'tava numa aula chata e, aí, ia p'ra uma aula do técnico, [...] que eram bem mais legais". Esta fala sugere satisfação desta ex-aluna em ter cursado o Ensino Técnico Integrado ao Médio, pois haveria proporcionado alternância de disciplinas do ensino médio com as do ensino técnico - consideradas mais prazerosas por esta respondente. Em relação à escolha da instituição, informou que seu irmão, naquela época, estaria cursando ensino médio em outra unidade da Etec. Relatou, ainda, que a Etec que frequentara seria recém-inaugurada. Quanto à opção pela área, declarou acreditar que o curso poderia Ihe trazer benefícios. De acordo com ela, "Era meio fora de mão p'ra mim. Apesar do local, eu queria muito fazer o curso, porque eu fui uma criança que não saía muito na rua e sempre gostei de mexer no computador". Seu relato sugere que, além de anterior familiaridade com ferramentas digitais, esta respondente apresentaria perfil mais introspectivo, condizente com a área da comunicação visual.

De modo geral, a opção por um curso técnico integrado ao ensino médio decorreria de orientação familiar; já a definição pela área da comunicação visual, aconteceria, principalmente, por influência de amigos. Os dados parecem indicar ausência de conhecimento dos alunos (sobretudo, os do Etim) a respeito da natureza do design gráfico ao escolherem o curso, seja pelas informações disponibilizadas pela instituição ou por falta de familiarização prévia. Assim, tenderiam a escolher em razão de afinidade por desenho, pintura ou por desejo de aprender a utilizar aplicativos gráficos. Por sua vez, alunos do ensino técnico não integrado ao médio procurariam o Curso Técnico em Comunicação Visual buscando descobrir a área profissional futura, para se prepararem para o mercado de trabalho ou, ainda, para servir-Ihes de ponte para o ensino superior. Estes resultados sugerem que parte da motivação da escolha por comunicação visual seria o fato (conhecido dos novos alunos) de que seus conteúdos estariam relacionados às artes plásticas. 


\subsubsection{2}

\section{Perspectivas de respondentes associados a escolas da rede Senac-SP}

A Respondente 37, ex-aluna, informou que, na época que iniciara o curso, já teria terminado o ensino médio há um ano e já estaria trabalhando, mas sem estudar. Para ela: "Esse ano, eu não sabia o que fazer, 'tava perdida. Aí, resolvi fazer o Técnico em Comunicação Visual. [...] Eu entrei com a mentalidade de achar uma coisa que eu ia fazer p'ra minha vida. [...] Eu olhava como uma coisa muito séria". Este relato sugere que esta respondente optara por cursar o ensino técnico visando identificar eventual afinidade com o campo da comunicação visual e, talvez, para seguimento no âmbito do ensino superior, bem como do mercado profissional.

De modo diverso, a Respondente 38, também ex-aluna, relatando seu próprio momento de vida e processo de escolha do curso, declarou que: "Eu 'tava no ensino médio, no terceiro. Eu não sabia de nada, só desenhar. Eu só sabia que tinha esse curso no Senac, me inscrevi, ganhei a bolsa, fiquei feliz e fui. Eu nem sabia, exatamente, o que era, porque eu não fazia parte desse universo". Esta declaração parece indicar que sua escolha ocorreu por anterior afinidade com o desenho, sem possuir exata noção da natureza da comunicação visual. Revela, ainda, que o fato de haver adquirido bolsa de estudos teria viabilizado seu aprendizado.

A Respondente 36, outra ex-aluna, também informou que só fez o Curso Técnico em Comunicação Visual por ter adquirido bolsa de estudo: "Eu consegui bolsa de 100\%. No técnico, eles [Senac] dão bolsa e, ainda, pagam seus materiais. [...] Eu não teria feito sem bolsa, por falta de condições”. Quanto a isto, a mesma Respondente 36 informou que comunicação visual não teria sido sua escolha inicial. Segundo ela, “Eu queria algo voltado p'r'o design, mas era mais p'ra desenhar roupas. Pensei em fazer técnico em moda, mas não consegui bolsa. Eu vi em comunicação visual, vi a grade, me interessei: vou tentar 'vê' se casa. Casou tanto, que eu desisti da moda". Sua fala parece indicar que a bolsa de estudo determinaria não apenas a possibilidade de estudar em um curso técnico, mas definiria sua futura área profissional.

Os dados apurados nesta seção parecem indicar que parte significativa dos alunos escolheria o Curso Técnico em Comunicação Visual do Senac-SP, ainda que sem 
conhecimento a respeito da natureza exata da atividade de comunicação visual, mas por gostar, por exemplo, de desenhar e/ou manipular imagens. Em geral, os alunos procurariam o curso técnico do Senac-SP para descobrir possível afinidade com a área, seja tencionando seguir o estudo em cursos superiores em design ou em campos afins, ou ainda objetivando posicionamento mais imediato no mercado de trabalho. $O$ fato de todas as três respondentes citadas nesta seção só haverem conseguido cursar tanto o ensino técnico quanto o ensino superior, em razão de bolsas de estudo que lhes foram concedidas, parece também ser aspecto relevante a informar sobre o perfil mais esforçado de parcela desses alunos.

\subsection{3}

\section{Expectativas iniciais dos alunos em relação ao curso técnico}

Os dados analisados na categoria temática apresentada nesta seção foram separados em subseções correspondentes às duas principais redes de escolas técnicas cobertas pela pesquisa: a Etec-SP e o Senac-SP.

\subsubsection{1}

\section{Perspectivas de respondentes associados a escolas da rede Etec-SP}

Quanto a expectativas iniciais em relação ao curso técnico, a Respondente 8, aluna do segundo módulo, revelou que já havia olhado o programa do curso antes de seu início e, apesar disso, "[...] eu não imaginava tantas matérias assim, de plástica, eu pensava que seria mais computador"; em referência à disciplina "Formas Expressivas Bidimensionais", considerando que plástica não fizesse parte da área: "Eu achava que fosse algo que puxasse p'ra área de design gráfico, que é a minha área de interesse". De modo similar, os Respondentes 9 e 10, igualmente do segundo semestre, e o Respondente 11, do terceiro, imaginaram tratar-se de um curso voltado mais ao ensino de aplicativos gráficos. Quanto a isto, o Respondente 9 declarou que, embora acreditando ser um curso com ênfase na "parte de edição", gostou de que houvesse mais técnicas manuais: "O meu objetivo real era aprender as técnicas, tanto no papel quanto no digital". 
Neste sentido, o Respondente 11, apesar do descontentamento inicial, considerou importante a oferta de "disciplinas manuais" ["Formas Expressivas Bidimensionais" e "Formas Compositivas de Elementos Plásticos"]. Para ele: "Depois, achei que contribuiu muito quando eu fui p'r'o computador, me incentivou a gostar de desenhar".

O Respondente 12, do terceiro módulo, também informou que havia se admirado "por ter muita coisa manual". Para ele, "Eu imaginava que iria desenhar fontes, criar imagens". Já o Respondente 10 mencionou ter se surpreendido, positivamente, com a área gráfica: "Meios de impressão, produção gráfica, achei importante porque, quando a gente tem uma noção de algo que a gente 'tá fazendo de forma extensa dentro da área, é melhor". De modo diverso, o Respondente 14, aluno do terceiro semestre, possivelmente por ser mais velho e já trabalhar, teria ingressado com boa noção a respeito do curso: "Não mudou muito a minha expectativa. Eu já sabia mais ou menos o que esperar do mercado, os tipos de software que você tem que dominar, como que você tem que ver". Por sua vez, para o Respondente 13, o curso teria superado suas expectativas, afirmando: "É um curso que tem a ver comigo, sou uma pessoa comunicativa, sou uma pessoa criativa, então, eu escolhi certo".

Já o Respondente 16, que cursava Ensino Técnico em Mecatrônica em outra unidade da rede Etec, por influência de dois amigos, optou por mudar para o Técnico em Comunicação Visual. Conforme sua declaração, parece que este aluno não havia se identificado com a área antecedente: "Eu queria algo diferente, uma coisa mais humana, talvez seja o principal motivo de eu ter vindo p'ra este Curso". Esta convivência com colegas também o informara sobre disciplinas e atividades, não apresentando, portanto, problemas com expectativas. Curiosamente, também seria a área de interesse do Respondente 14, outro aluno, que concluíra o Ensino Técnico em Mecatrônica antes de iniciar o de Técnico em Comunicação Visual. Destaque-se a utilização da expressão "mais humana", sugerindo preferência por conteúdos mais voltados para aspectos sociais das diversas realidades humanas.

Os dados analisados sugerem que, em geral, os alunos que procurariam cursos técnicos de comunicação visual de escolas da rede Etec-SP já ingressariam no curso com expectativa de ter parte significativa das aulas em laboratório de informática para aprender a utilizar os aplicativos gráficos na execução de trabalhos. 
Embora parcela considerável de alunos houvesse relatado prévia investigação a respeito dos conteúdos e atividades do programa de comunicação visual, a maioria se surpreenderia com o grande volume de trabalhos relacionados às artes plásticas a serem executados em disciplinas como, por exemplo: "Formas Expressivas Bidimensionais" e "Formas Compositivas de Elementos Plásticos".

\subsubsection{2}

\section{Perspectivas de respondentes associados a escolas da rede Senac-SP}

Quanto a expectativas iniciais em relação ao Curso Técnico em Comunicação Visual, o Respondente 33, aluno, informou que havia "caído de paraquedas" no Curso e que esse não corresponderia ao que imaginara. Segundo ele, "Quando eu comecei, eu não esperava que fosse ter tanto de design gráfico, eu achei que ia ser comunicação visual como um todo. [...] Pensava que era bem um cenário global", considerando que comunicação visual compreenderia áreas como fotografia, vídeo, espaço físico, cultura e moda. Apesar disto, relatou não ter se desapontado: "Mas eu achei legal que foi voltado mais p'ra parte de design gráfico, que é uma área que eu me identifico bastante. Eu sou fotógrafo". Uma possível explicação para esta sua percepção, pouco aceita no campo, de que as atividades de comunicação visual e do design gráfico seriam, afinal, assim tão distintas, seria a de que o termo comunicação visual sugeriria qualquer manifestação visual, e não necessariamente voltado a projetos gráficos.

De modo similar, a Respondente 38, ex-aluna, narrando sua percepção quanto ao Curso antes do seu início, como parcialmente citado no item 4.1.2.2, também informou não possuir anterior conhecimento sobre a área da comunicação visual. Para ela, "Eu nem sabia exatamente o que era, porque eu não fazia parte desse universo. Me identifiquei justamente por causa da arte, do desenho, [...] edição de imagens. Eu fazia muito p'ra joguinhos online. [...] Nunca tinha mexido no Photoshop antes". Observe-se que esta respondente, antes de ingressar no Curso Técnico em Comunicação Visual, apresentaria alguma habilidade para desenhar e editar imagens em aplicativo, ao que parece, de forma rudimentar. Isto sugere que algumas pessoas, com perfil mais criativo, iniciariam este curso sem prévio 
conhecimento a respeito do campo e atribuições inerentes ao profissional da área, não tendo criado, portanto, expectativas em relação ao mesmo.

Por sua vez, o Respondentes 34, aluno, informou ter se surpreendido com a quantidade de conteúdos teóricos no início de seu curso técnico: "Eu achei que ia ser muito mais prático do que teórico. Mais prática do software. Aí, foi mais teoria do que na prática. [...] Ao longo do curso, fui entendendo do assunto, já foi mudando a minha opinião. [...] Eu não gosto muito de teoria, mas é bom". Esta também teria sido a ideia inicial do Respondente 35, outro aluno, ao afirmar que: "Eu 'tava com uma coisa na cabeça que ia ser mais uma parte de criação, algo mais operacional e menos teórico. [...] Hoje, eu vejo que realmente fazia sentido, acabou que teve um significado. Quando você vê, já 'tá praticando". Estes relatos sugerem que cursos técnicos, de modo geral, seriam percebidos como algo mais prático e que haveria certa resistência, ao menos destes alunos, a abordagens teóricas. Sugerem, também, que a base teórica inicial do programa estaria sendo notada como importante, ainda que um pouco tardiamente, até no sentido de contribuir para atenuar a visão negativa associada a componentes teóricos, além de apontar a prática mais concreta do projeto.

A Respondente 37, ex-aluna citada, mencionou que teria superado suas expectativas iniciais em relação ao Curso Técnico em Comunicação Visual: "Quando eu entrei, achei que ia 'sê' mais superficial do que foi. Um ano só, a faculdade dura quatro. Mas foi mais 'pauleira'. Eu gostei, porque eu comecei a gostar de design. Aí, eu queria aprender mais. Então, eu tinha que ir p'ra graduação". Este trecho do seu depoimento sugere que cursos técnicos seriam percebidos como menos significativos em função do tempo, notado como mais encurtado. Neste caso específico, teria despertado interesse desta respondente em se aprofundar na área e seguir seus estudos na graduação.

Em contrapartida, a Respondente 36, outra ex-aluna, como citado na seção 4.1.2.2, teria entrado em comunicação visual por ter sido o curso em que conseguira uma bolsa de estudo: "Eu queria algo voltado p'r'o design, mas era mais p'ra desenhar roupas. Pensei em fazer técnico em moda, mas não consegui bolsa. Eu vi em comunicação visual, vi a grade, me interessei: 'vou tentar 'vê' se casa'. Casou tanto, 
que eu desisti da moda". Observe-se que o Curso Técnico em Comunicação Visual não seria a primeira opção de escolha desta respondente. Ela teria preferência por cursar Técnico em Produção de Moda. Isto parece indicar que a Respondente 36 não teria criado grandes expectativas em relação ao curso. Pressupõe, ainda, que seu anterior interesse por design, mesmo não sendo o gráfico, teria contribuído com sua declarada satisfação com a área cursada.

Os dados sistematizados acima sugerem que parte significativa dos alunos, antes de iniciar o curso técnico, não faria ideia clara sobre a natureza exata da atividade da comunicação visual, equiparando a atividade da comunicação visual a qualquer manifestação visual, não necessariamente relacionada a projetos gráficos. Assim, pressuporiam que as atividades pedagógicas teriam caráter mais estritamente prático, sendo destituídas, ao que imaginaram, de conteúdos teóricos. Outros, ainda, considerariam que o curso fosse menos aprofundado em função da brevidade geral do programa (cerca de um ano e meio).

\subsection{4}

\section{Habilidades consideradas relevantes na profissão do design gráfico}

Os dados analisados na categoria temática apresentada nesta seção foram separados em subseções correspondentes às duas principais redes de escolas técnicas cobertas pela pesquisa: a Etec-SP e o Senac-SP.

\subsubsection{1}

\section{Perspectivas de respondentes associados a escolas da rede Etec-SP}

Em relação às habilidades consideradas relevantes na profissão de design gráfico, os alunos do ensino técnico não vinculado ao médio apontaram: ter criatividade; ser curioso; possuir facilidade de comunicação; nutrir empatia pela ideia do cliente; ter pensamento crítico para, por exemplo, saber diferenciar as coisas; ser flexível; mostrar comprometimento com prazos, além de dominar o uso de programas gráficos. Como qualidades complementares, o Respondente 13 mencionou, 
como primordial, "Tem que ter um olhar diferente p'r'as coisas em geral, ver o que ninguém enxerga". Já o Respondente 9 declarou que seria importante não pensar em estereótipos, enquanto o Respondente 10 apontou, como essencial, saber lidar com as diferenças, porque nem sempre consegue-se executar aquilo que se imaginou. Em marketing, segundo a Respondente 8, seria fundamental saber direcionar o olhar para o público específico. Já a Respondente 15 classificou o comunicador visual como: "[...] aquele que consegue captar o que o cliente quer e passar através de áudio, vídeo, desenho ou figura”.

Por sua vez, alunos do Etim apontaram como habilidades identificadas relevantes na profissão de design gráfico: possuir criatividade; ser capaz de lidar muito bem com o tempo; ter a cabeça bastante aberta; ater-se a detalhes; possuir noção de desenho; demonstrar facilidade de comunicação; ter conhecimento de formas e cores, além de apresentar destreza no uso de programas gráficos. Como qualidades complementares, a Respondente 18 aludiu, como relevante: "Ter perspectivas de novos jeitos, ideias inovadoras para conseguir passar bem a mensagem". Já a Respondente 19 declarou: "Precisa ter vontade, precisa praticar" e, em marketing, saber lidar com clientes e seu público, o que corrobora com o Respondente 14, ao considerar que: "Comunicação visual é um pouco de marketing também, tem que vender o produto da pessoa. P'ra isso, a gente tem que atingir o público dele".

Estes resultados, apesar de muito diversos, demonstrariam certo entendimento sobre algumas habilidades necessárias para a atuação profissional como designer gráfico. Em marketing, seria o momento em que os alunos vislumbrariam a importância do papel do cliente e dos clientes do cliente, parecendo sugerir, mesmo que de maneira oblíqua, ideia de usuário.

\subsubsection{2}

\section{Perspectivas de respondentes associados a escolas da rede Senac-SP}

Em relação às habilidades consideradas relevantes na profissão do design gráfico, o Respondente 33, aluno, pontuou como essencial ter posicionamento em relação ao sujeito para quem se está projetando. De acordo com ele, "[...] a parte de software, 
diagramação ou pensar na organização de um livro, todo mundo consegue aprender. Mas a parte de se abrir e ter sensibilidade ao que o outro 'tá precisando, é completamente diferente". Esta visão pressupõe que habilidades operacionais seriam mais facilmente assimiladas, enquanto a empatia requereria mais tempo, sendo mais importante para a formação do designer, uma vez que sugeriria afinidade ao processo de design centrado no humano.

Por seu turno, o Respondente 35, outro aluno, declarou que a habilidade essencial de um designer gráfico seria a versatilidade. Para ele: "[...] tem que ser especialista em uma coisa e saber de tudo um pouco. [...] é necessário essa parte referencial. [...] você 'lincar' bem algo que já viu com o que o cara 'tá querendo. [...] tem a referência, só que você vai transformar a sua referência". Seu depoimento pressupõe que o designer necessitaria formar um repertório amplo e variado, que contribuísse como estímulo e inspiração para o desenvolvimento de projetos.

Esta mesma visão, em parte, foi defendida pelo Respondente 34, também aluno. De acordo com ele, "Buscar referência p'ra ter uma comunicação visual. [...] Saber usar o software, saber usar um grid, sempre manter um conceito. Sem um conceito, eu acho que uma arte fica vazia". Esta fala parece indicar que, além de formar repertório abrangente, como defendido pelo Respondente 35, o designer deveria apresentar habilidade de usar aplicativos gráficos, utilizar malha gráfica na estruturação de trabalhos e, sobretudo, saber direcionar apropriadamente o projeto a partir de prévia contextualização do mesmo.

Os dados analisados parecem indicar como habilidades consideradas relevantes na profissão de design gráfico: formação de repertório extenso e diversificado para fazer frente a demandas variadas de projeto; contextualização do projeto antes de seu início para direcionamento assertivo; destreza no uso de aplicativos e malhas gráficas; além disto, ter empatia com o destinatário final do projeto. 


\subsection{5}

\section{Percepções sobre a natureza do design gráfico (ou comunicação visual) ${ }^{5}$}

Os dados analisados na categoria temática apresentada nesta seção foram separados em subseções correspondentes às duas principais redes de escolas técnicas cobertas pela pesquisa: a Etec-SP e o Senac-SP.

\subsubsection{1}

\section{Perspectivas de respondentes associados a escolas da rede Etec-SP}

Quanto às percepções sobre a natureza do design gráfico, o Respondente 17, aluno do Etim, declarou que seria muito aberto, "tenso", com grande diferença de habilidades. O mesmo Respondente 17, ao relatar que teria entrado no Curso sem ideia a respeito da área, informou estar aprendendo bastante coisa. Segundo ele: "Eu não tinha noção nenhuma, agora eu já sei mais ou menos, [...] como a mídia é manipuladora". Já a Respondente 19, igualmente aluna do Etim, informou que consideraria importante desenvolver campanhas inteligentes. Os demais designaram o design gráfico como sendo criação de logotipos e suas aplicações, cartazes, panfletos, livros, brindes e manuais de identidade visual por meio de diagramação, perspectivas e técnicas diversas.

Por sua vez, a Respondente 23, ex-aluna, relatando sua percepção sobre a comunicação visual antes de seu ingresso no curso técnico, mencionou que não teria ideia a respeito do campo, não o relacionando com o design. Segundo ela, "Eu nem sabia que comunicação visual era design. Só foi um clique que eu tive, muito tempo depois, já na faculdade. Talvez, se fosse design o nome, fosse um pouco melhor. [...] Comunicação visual é um pouco vago". De modo bastante similar, o Respondente 12, aluno, declarou ser uma área muito abrangente, com a ressalva de que "[...] esse nome, comunicação visual, não vende o que é o curso, se vende, vende um negócio errado. [...] Eu acho que deveria ser um nome que lembrasse design, mais do que comunicação visual". Tais declarações sugerem

\footnotetext{
${ }^{5} \mathrm{Na}$ definição dos conceitos, as expressões 'comunicação visual' e 'design gráfico' são empregadas indistintamente como termos sinonímicos, de maneira intercambiável.
} 
que a denominação "Técnico em Comunicação Visual" estaria contribuindo para desorientação quanto à real atribuição da área.

Outro relato sugere percepção da abrangência do campo da comunicação visual, com diversificados segmentos de atuação. Segundo a Respondente 28 , outra ex-aluna, "Comunicação visual é uma boa pincelada. Você consegue desenvolver muitas coisas e, talvez, o valor que você mais deva apreciar sendo um profissional de design gráfico seja a autenticidade e a criatividade que se imprime em algum trabalho". Sua fala pressupõe valorização de profissionais que busquem soluções de design diferenciadas, imprimindo, em seus trabalhos, uma linguagem própria.

Para a Respondente 8, aluna, "[...] comunicação visual é tudo que consegue transmitir uma informação sem, necessariamente, ser com palavras. [...] Pode existir cartaz só com imagens e, também, complementando imagem com texto". Quanto a isto, o Respondente 9, outro aluno, declarou enfaticamente: "Como você impacta nas pessoas". Comentou que o importante seria analisar o público: "Você analisa e pensa uma mensagem efetiva p'ra aquilo. Não precisa ser técnica, às vezes, pode ser só uma imagem ou uma palavrinha simples, uma gíria, vai atingir a pessoa". Já o Respondente 11, igualmente aluno, informou considerar uma área interessante de se trabalhar, com bastante amplitude de atuação. Analogamente, em referência às áreas de atuação, a Respondente 1, professora, mencionou que: "[...] comunicação visual não é fácil e, apesar de ser uma área muito aberta, oferece muitas possibilidades". Já a Respondente 15, outra aluna, aludindo possivelmente à própria incerteza quanto a uma adequada significação, declarou: "[...] ninguém sabe exatamente o que é comunicação visual".

Para o Respondente 11, aluno já citado, comunicação visual abrangeria mais a criatividade, embora fosse limitada pelo cliente. E completa: "Talvez, seja um mercado bom atualmente já que, futuramente, vamos precisar de mais freelancers do que estes trabalhos atuais". A este respeito, o Respondente 13, também aluno, informou estar preocupado com seu futuro profissional. Segundo ele, "[...] o mercado de trabalho 'tá meio complicado, meio difícil. 'Tô' meio inseguro se eu vou conseguir trabalhar na área. É uma área que a gente vai ter que 'tá sempre estudando e reaprendendo". Aspecto notável foi a divergência de percepção quanto 
ao mercado de trabalho: enquanto um aluno estaria preocupado em conseguir trabalhar na área, outro acreditaria ser um bom campo para trabalhar por conta própria.

Os dados examinados acima parecem indicar certo entendimento quanto à natureza da comunicação visual, com ênfase em sua amplitude, embora se observe certa confusão conceitual sobre a área, em referência ao aprendizado de que a "mídia é manipuladora", incorporando, mais acentuadamente, aspectos ideológicos e de persuasão. Além disto, a percepção sobre a carreira parece fragmentada pelo material e tipo de atividade de cada disciplina, tal como citado: "[...] até em relação ao papel também, então, meu nível de desenho melhorou bastante comparado ao antes de entrar aqui". Note-se, também, outro equívoco, conforme esta declaração: "Este curso de comunicação visual é uma base p'ra outras áreas, como a publicidade, ilustração, jornalismo e o design em si" [ênfase acrescentada pela autora para salientar trecho relevante à análise subsequente]. Este relato parece presumir que design seria o mesmo que design de produto e sugerir que comunicação visual não se relacionaria ao design, que seria uma outra coisa.

\subsubsection{2}

\section{Perspectivas de respondentes associados a escolas da rede Senac-SP}

Este aspecto, também comentado na seção 4.1.3.2, trata da percepção do Respondente 33, um aluno, a respeito da comunicação visual antes de ingressar no curso: "Eu tinha em mente ter um panorama bem global de tudo que transmitia uma informação de imagem, uma comunicação que era visual. [...] Eu achava que ia ser mais coisas e menos aprofundadas", considerando que comunicação visual compreenderia áreas como fotografia, vídeo, espaço físico, cultura e moda. Apesar do descontentamento inicial, identificou-se com a área: "E minha surpresa foi chegar aqui e ver que a gente "tava aprofundando completamente no design gráfico". Esta sua observação remete a uma compreensão alargada do conceito de comunicação visual, abrangendo também manifestações das artes visuais, não necessariamente vinculadas, de modo direto, à especificidade do campo do design gráfico, visão que parece mais prevalente na cultura dos cursos técnicos visitados. 
Ideia semelhante a respeito da comunicação visual foi relatada pelo Respondente 34, outro aluno: "É tudo o que a gente vê. Tudo o que você vê gera a comunicação. Nas placas, tudo. Às vezes, pode mostrar o perigo, o que não pode. [...] Sinalização é tudo. Lugar que não tem, vira bagunça". Novamente aqui, o termo comunicação visual seria interpretado como algo que comunique por meio do sentido da visão, nem sempre de forma intencional, como em um projeto gráfico. Já para o Respondente 35, igualmente aluno: "Comunicação visual eu acho algo essencial, básico. Sem comunicação, não tem existência. Acaba que explica as coisas. Você acaba que consegue passar visões, consegue ter interpretações, tudo através da comunicação visual". Seu relato sugere percepção de que a comunicação visual estaria associada à função primordial de informar.

Os dados apurados nesta seção parecem indicar que o próprio nome deste curso técnico estaria contribuindo, em certos casos, para uma interpretação vaga e nem sempre acertada de sua proposta, que seria a de ensinar os fundamentos e, sobretudo, a prática do design gráfico.

\subsection{6}

\section{Percebida vocação pessoal para a área da comunicação visual}

Os dados analisados na categoria temática apresentada nesta seção foram separados em subseções correspondentes às duas principais redes de escolas técnicas cobertas pela pesquisa: a Etec-SP e o Senac-SP.

\subsubsection{1}

\section{Perspectivas de respondentes associados a escolas da rede Etec-SP}

Quanto à percebida vocação para a área da comunicação visual, o Respondente 9, aluno, mencionou que, no início do curso, tinha suas dúvidas e que, da metade para frente, acreditaria que sim, mas com certa reserva: "Apesar de eu ter certa afinidade em desenhar, comunicação visual é bem mais. Você precisa pensar em um monte de coisas". Esta declaração sugere noção de que as habilidades consideradas 
necessárias para atuação de um comunicador visual compreenderia muito mais aspectos do que saber desenhar. Já o Respondente 11, outro aluno, mencionou possuir vocação para a área, mas com a seguinte ressalva: "[...], se for p'ra área digital, eu vou conseguir bem. Mas manual, não. Questão criativa, eu tenho bastante. Aprendi a não valorizar esses desenhos fantásticos. Porque, p'ra mim, o bonito "tá no simples, não no complexo". Estes argumentos parecem sugerir que este aluno apresentaria uma ideia mais clara a respeito da natureza distinta entre comunicação visual e ilustração.

O Respondente 16, outro aluno, em relação à possível aptidão para design gráfico, informou: "Eu vim descobrir isso aqui. Acho que no momento, não. Eu ainda tenho muitos caminhos a pensar, muitos lugares p'ra ir". De modo bastante similar, o Respondente 10, também aluno, declarou: "P'ra exercer a profissão, no momento, não, porque eu acho que eu tenho bastante coisa p'ra melhorar ainda. Talvez como freelancer, dependendo do que fosse". Já o Respondente 12, igualmente aluno, declarou ter afinidade com a área, mas teria preferência por arquitetura. Estes relatos parecem indicar percepção de que a formação na área do design gráfico, mais do que ter afinidade com a área, demandaria intensa dedicação.

Por sua vez, o Respondente 13, também aluno, declarou se considerar bem qualificado: "Sou criativo, muito objetivo. Sou uma pessoa bem capacitada". De maneira análoga, o Respondente 14, outro aluno, relatando sua própria capacidade para ordenar, declarou: "Tenho, bastante vocação, eu nasci p'ra isso. Eu consigo organizar e acho que é o que o comunicador visual faz, ele organiza as coisas p'ra que fique bonito, p'ra que as pessoas olhem e ache agradável. Além de ficar bonito, tem que ser funcional". Ainda, quanto à possível vocação para comunicação visual, a Respondente 15, aluna, relatou que aprendera no Curso a amplitude da atuação profissional desta área: "Agora eu sei como extrair o melhor de cada pessoa p'ra conseguir um objetivo final. Eu seria uma ótima vendedora [área de atendimento]. Eu vou dar exatamente o que o cliente quer porque eu consigo passar isso p'r'as outras pessoas da equipe". Esta fala sugere possível atuação para além do campo do design. 
Os dados sistematizados nesta seção parecem indicar que alunos de cursos técnicos de comunicação visual de escolas da rede Etec, de modo geral, relacionariam a possível vocação para a área com a capacidade criativa e organizacional. Neste sentido, apontaram a amplitude da área de formação e necessidade de empenho pessoal para desenvolvimento de uma gama de habilidades que possibilitariam uma atuação mais assertiva.

\subsubsection{2}

\section{Perspectivas de respondentes associados a escolas da rede Senac-SP}

Quanto à percebida vocação pessoal para a área, o Respondente 34, aluno, apontou seu anterior interesse pela comunicação e pela abordagem mais técnica, executiva. Para ele, "Acho que sim. Eu sempre gostei de comunicação. Ainda mais na área de software, sempre gostei de produzir". Já o Respondente 33, também aluno, embora considerasse possuir talento, apresentaria certa reserva: "Não tanto quanto eu tenho p'ra fotografia, mas sinto que eu 'tô' [...] aprendendo a produzir melhor nessa área, ser mais criativo. A fotografia, eu aprendi sozinho e é muito diferente quando você tem alguém p'ra te ensinar a trabalhar". Este depoimento reforça a ideia de que os conteúdos passados e, sobretudo, a didática praticada seriam adequados para o desenvolvimento de habilidades necessárias para atuação profissional na área.

A este respeito, o Respondente 35 também destacou, como essencial, ter afinidade especificamente com a área do design, uma vez que a mesma requereria muita dedicação. Para ele: "Se você não gostar de design, não viver design, não vai rolar. Você tem que estar sempre estudando, sempre vendo. [...] Buscar referência num lugar que ninguém imaginaria que sairia alguma coisa. Acho que isso acaba sendo vocação". Esta declaração sugere ênfase do curso em incentivar os estudantes a entrarem em contato com variados trabalhos e temáticas, buscando a sensibilização e formação de repertório, que possibilite, por sua vez, contribuir como estímulo para outros trabalhos. 
Os dados analisados pressupõe que parte dos alunos de cursos técnicos de comunicação visual de escolas da rede Senac-SP entenderiam a presumível vocação para a área como a tendência pessoal por abordagens de caráter mais técnico, gosto pelo ato de produzir e empenho na busca por referências que inspirem novos projetos.

\subsection{7}

\section{Perspectivas profissionais futuras de alunos cursando o ensino técnico}

Os dados analisados na categoria temática apresentada nesta seção foram separados em subseções correspondentes às duas principais redes de escolas técnicas cobertas pela pesquisa: a Etec-SP e o Senac-SP.

\subsubsection{1}

\section{Perspectivas de respondentes associados a escolas da rede Etec-SP}

Em relação às perspectivas profissionais futuras, o Respondente 14, aluno do modular noturno, declarou intenção de se profissionalizar em histórias em quadrinhos.

Para ele, "Eu gosto de comunicação visual, acho que eu me daria muito bem numa agência, mas eu pretendo viver de história em quadrinhos". Mencionou, também, ter ficado satisfeito com seu progresso em distribuir adequadamente os elementos em uma página: "O curso melhorou, inclusive, minha visão das páginas de quadrinhos, de como fazer porque, de certa forma, é uma diagramação também". Em contrapartida, a Respondente 19, aluna do Etim, declarou que viveria de ilustração, pois, segundo ela, "[...] o trabalho dos sonhos, assim, seria ilustrar livros". De maneira semelhante, a Respondente 18, também aluna do Etim, em referência ao "design de personagens", demonstrou interesse por ilustração, mas também se identificaria com design de produto.

De modo diverso, relatando sua então incerteza quanto à escolha profissional futura, o Respondente 13, outro aluno do modular noturno, informou que gostaria de fazer faculdade na área de comunicação, mas que, até aquele momento, não teria se definido: estaria entre rádio TV, relações públicas, publicidade ou jornalismo. 
De modo análogo, o Respondente 22, igualmente aluno do Etim, mencionou que gostaria de estudar artes, rádio TV ou audiovisual. Similarmente, a Respondente 7, outra aluna do Etim, relatou que tencionaria cursar audiovisual na parte de produção de filmes, com ênfase em ilustração digital, e que descobrira tal afinidade durante o curso. O Respondente 21, também aluno do Etim, declarou não pretender seguir a área do design gráfico, mas de jornalismo, afirmando que os conceitos de diagramação e tipografia aprendidos poderiam ser úteis a ele.

Já o Respondente 11, outro aluno do modular diurno, informou que nem desejava, a princípio, estar cursando o ensino técnico de comunicação visual, mas algo ligado à música. Para ele, "Meu sonho é ter uma banda de folk rock ou folk metal. Pretendo fazer faculdade de música, mas primeiro de design. 'Tô' vendo isso como modo de ganhar dinheiro". Design também seria a escolha profissional do Respondente 10, também aluno do modular diurno. Segundo ele, "Eu gostaria, no futuro, de dar aula de design gráfico. Fazer faculdade de design gráfico e licenciatura”.

Já o Respondente 17, outro aluno do Etim, declarou que gostaria de fazer faculdade de artes visuais e, igualmente, de letras. O Respondente 16 , um aluno do modular diurno, também relatou pretender se aprofundar na "arte em geral" ou, ainda, desenhar cenários. O design [gráfico e de produto] também seria uma possibilidade. Além disto, especulou: "Talvez eu faça Técnico em Design de Interiores e, se eu achasse legal, eu pensaria em fazer faculdade de arquitetura". A este respeito, a Respondente 8, outra aluna do modular diurno, informou que teria sido sua ideia inicial: "Pensei em fazer arquitetura e, depois, ouvi pessoas falando sobre design gráfico. Aí, eu vim fazer comunicação visual p'ra ver se eu me encontrava e, acabou que deu certo". Declarou intenção de fazer faculdade de design digital, adquirir experiência em empresas no Brasil e, na sequência, tentar carreira em outros países. A arquitetura também seria a escolha profissional do Respondente 12, outro aluno do modular diurno. Relatou, como meta de vida, ter seu próprio negócio. Para ele, "[...] meu sonho é criar uma empresa que tenha tudo que envolva criação. Vai ter um andar de arquitetura, um de fotografia e um de design". Isto sugere que este respondente, ao pretender dispor de um "edifício criativo", apresentaria perfil considerado mais impetuoso. 
Por seu turno, o Respondente 9, outro aluno do modular noturno, que estaria cursando simultaneamente Tecnologia em Sistemas Elétricos, informou tencionar fazer pós-graduação em gestão e marketing. De acordo com ele: "Meu objetivo é abrir uma empresa e ficar tranquilo. Na verdade, eu já sou sócio em outras duas [curso on-line e contabilidade] e vou abrir a minha nesa parte de elétrica mesmo". Neste sentido, o Respondente 9, com seu perfil empreendedor, parece ser mais realista, em relação às aspirações dos Respondentes 8 e 12, ao pretender abrir uma empresa de elétrica, em São Paulo mesmo.

De modo bastante diverso, a intenção da Respondente 15, outra aluna do modular noturno, seria continuar estudando. Para ela, "Eu sempre viajei, nunca precisei terminar o ensino médio, nunca me liguei em estudo". Declarou ter cursado EJA [Educação de Jovens e Adultos] em uma escola pública, onde adquiriu gosto pelo estudo. Na sequência, fez Técnico em Design de Interiores e estaria cursando, naquele momento, Técnico em Comunicação Visual.

Os dados sistematizados nesta seção, concernentes a perspectivas profissionais futuras de alunos cursando o ensino técnico, parecem indicar que, além de design (gráfico, de produto ou digital) e de arquitetura, parte dos alunos almejaria prosseguir estudando em artes visuais ou em campos associados às artes, tais como: ilustração, rádio TV, audiovisual, relações públicas, publicidade e propaganda, jornalismo, marketing ou música; outra parcela menor parece nutrir aspirações consideradas mais arrojadas, como tentar carreira no exterior. Além disto, os depoimentos sugerem que cursos técnicos seriam percebidos como uma espécie de teste para a definição de possível afinidade com a área.

\subsubsection{2}

\section{Perspectivas de respondentes associados a escolas da rede Senac-SP}

Em relação às perspectivas profissionais futuras, o Respondente 33, aluno, considerou importante a ampliação de conhecimento em áreas afins. De acordo com ele, "Atualmente, eu mais trabalho com foto e vídeo. Não quero trocar a área. Quero trabalhar com design gráfico em paralelo, [...] com design visual como um 
todo". Seu depoimento sugere que alguns alunos procurariam o curso não por estarem insatisfeitos com a área profissional, mas com ideia de complementar e expandir o campo de atuação.

Em contrapartida, o Respondente 34, outro aluno, mencionou tencionar dar continuidade aos estudos: "Primeiramente, me formar [no técnico] em comunicação visual. Acho que, depois, entrar numa faculdade de publicidade e propaganda. Buscar mais conhecimento e abrir uma agência p'ra mim. É o que eu espero". A intenção de cursar especificamente essa graduação pressupõe presença de conteúdos e abordagens da área de publicidade e propaganda no Curso Técnico em Comunicação Visual do Senac-SP. Este relato também sugere desejo futuro de trabalhar em um negócio pessoal.

Esta mesma ideia de trabalhar por conta própria foi descrita pelo Respondente 35: "Hoje, eu quero pegar uma bagagem maior em agência, com criação. Futuramente, tentar fazer algo que seja útil. [...] criação de paz, identidade visual, algo que tenha mais valor e que agregue valor financeiro [...]. Um escritório meu, sem equipe". Seu relato sugere vontade deste respondente em, inicialmente, adquirir experiência de mercado que possibilite ser aplicada, em um segundo momento, em projetos mais relacionados à dimensão do social. Quanto à continuidade dos estudos, o mesmo Respondente 35 cogitou fazer uma graduação. Para ele, "De faculdade, eu gostaria de fazer design gráfico. [...] A faculdade é mais teórico, algo mais base. Fez a base, quero fazer uma pós". Sua fala pressupõe entendimento da necessidade de se vivenciar o mercado de trabalho antes de se aventurar em um negócio próprio. Sugere, também, que o Curso Técnico em Comunicação Visual despertaria, em alguns alunos, interesse em se aprofundar nos estudos na própria área do design gráfico.

Estes depoimentos sugerem que os conteúdos a que os alunos são expostos estariam, em certa medida, despertando o interesse, de parte significativa deles, a prosseguirem seus estudos ou, também, a expandirem seu campo de atuação profissional. Pressupõem, ainda, que a instituição despertaria a veia empreendedora de parte de seus estudantes. 


\subsection{8}

Percebidas diferenças relatadas por egressos de cursos técnicos de comunicação visual em São Paulo quanto ao desempenho, em cursos universitários de design ou campos afins, de alunos que, como eles, hajam cursado o ensino técnico em comunicação visual em relação a seus colegas de turma

Os dados analisados na categoria temática apresentada nesta seção foram separados em subseções correspondentes às duas principais redes de escolas técnicas cobertas pela pesquisa: a Etec-SP e o Senac-SP.

\subsubsection{1}

\section{Perspectivas de respondentes associados a escolas da rede Etec-SP}

A Respondente 25, ex-aluna, declarou notar diferença entre seu desempenho em aplicativos gráficos e de seus colegas de turma na graduação em design. Segundo ela: "Até o final do $1^{\circ}$ ano, como eu já sabia mexer em grande parte dos softwares, eu discutia com o professor mais coisas do projeto em si. Agora, o pessoal que não tinha conhecimento, ele ficava discutindo o refinamento do trabalho mesmo". Sua fala parece indicar que o conhecimento prévio de aplicativos gráficos favoreceu a esta respondente executar trabalhos com mais destreza e acuidade, dispondo o precioso tempo de atendimento para questões mais intrínsecas ao projeto. Além disto, mencionou outra contribuição importante do ensino técnico que a diferenciaria dos demais colegas: "Eu acho que é mais o rigor visual mesmo. É uma questão básica de alinhamento, de composição etc. [...] Eu sempre dou uma arrumadinha depois". Esta passagem sugere que ela teria desenvolvido, antes mesmo de seu ingresso na graduação, competências vistas no campo do design gráfico como sendo especialmente relevantes: a precisão na execução dos trabalhos e a percepção visual.

Em contrapartida, a Respondente 27, igualmente ex-aluna, comentando sua maior destreza em relação a seus colegas da faculdade de arquitetura, mencionou a realização de certa atividade. Segundo ela, "[...] o trabalho de planejamento urbano, que tinha que ficar pintando lotezinho de cada cor, as pessoas faziam à mão, 
deu um super trabalho. Eu fiz no Illustrator, muito rápido. Sem o técnico, eu não ia nem saber que existia programa de computador". Esta declaração parece indicar que conhecimentos ferramentais de programas gráficos adquiridos no Curso Técnico em Comunicação Visual e suas possibilidades para execução de variados projetos haveriam contribuído, eficientemente, para a realização de determinada atividade na graduação em arquitetura, distinguindo-a dos demais alunos.

Por outro ponto de vista, a Respondente 23, ex-aluna, comparando seus próprios conhecimentos com os de outros alunos de sua turma da faculdade de design, mencionou perceber grande diferença, principalmente no início do curso. Para ela, "[...] no comecinho, é bom você ter alguma base, é bom você saber o que é Bauhaus, [...] Escola de Ulm, [...] Gestalt, como abrir um Photoshop, um Illustrator. É bom saber esses conceitos básicos. Se não, é meio assustador chegar sem saber nada". Esta passagem parece indicar que os fundamentos das escolas pioneiras de design, princípios da Gestalt e aspectos mais ferramentais de aplicativos gráficos teriam sido tratados no ensino técnico de comunicação visual e reconhecidos como relevantes.

A mesma Respondente 23, citando outros conteúdos abordados na faculdade, informou já terem sido apresentados no curso técnico. Segundo ela, "Em relação à teoria e exercícios de cor e à composição, o que eu tinha visto no ensino técnico, eu voltei a ver na faculdade. Mas pelo menos, eu tinha alguma vantagem em relação aos demais alunos". Note-se que conteúdos e exercícios percebidos como importantes na faculdade de design teriam sido tratados, anteriormente, no curso técnico. Isto sugere que competências desenvolvidas nestes quesitos possibilitaram a esta respondente maior destreza, em relação à sua turma, para execução de determinados trabalhos na faculdade.

Complementarmente, o Respondente 26, outro ex-aluno, relatando sua percepção quanto ao próprio desempenho em relação ao de seus colegas, sobretudo no início do curso, mencionou que: "Em práticas de material, eu sabia como usar um estilete e uma régua de corte, eu sabia usar algumas tintas, guache, aquarela, acrílica, por exemplo. Eu sabia preparar prancha de apresentação de trabalhos, tinha noção de desenho geométrico". Observe-se que este respondente teria adquirido, no ensino técnico de comunicação visual, habilidades mais manuais e isto sugere abordagem 
mais empírica, mais associada às artes plásticas, neste curso. Ainda, relativamente à tais habilidades, o mesmo Respondente 26 afirmou que executaria os trabalhos mais rapidamente. De acordo com ele, "Eu perdia muito menos tempo nas aulas de projeto, de ateliê, de 'Fundamentos do Projeto de Arquitetura' e em 'Geometria Aplicada à Produção Arquitetônica' também. Eu tinha muita agilidade p'ra fazer os desenhos e facilidade p'ra fazer os exercícios". Sua fala pressupõe que habilidades assimiladas no curso técnico, principalmente as mais manuais, teriam favorecido este respondente, melhorando seu desempenho nas disciplinas de projeto de arquitetura na graduação. Quanto à sua performance em outras disciplinas, relatou ter se sentido mais preparado. Segundo ele: "A gente tinha que produzir pôster p'ra apresentar trabalho na aula de história. [...] O do meu grupo sempre 'tava muito bonito, o pessoal elogiava bastante". Esta passagem sugere que, mesmo em disciplinas teóricas e nos trabalhos em equipe, as habilidades manuais deste respondente haveriam colaborado para apresentações diferenciadas.

Já a Respondente 28, igualmente ex-aluna, aludindo a suas próprias características que a distinguiria do restante da sala, mencionou que: "Eu sempre tive muito olhar p'r'as coisas. Porque, se você não sabe identificar as coisas, não tem como você produzir [...]. Se você quer fazer acontecer, se tornar alguém de verdade e fazer coisas relevantes, você precisa procurar por elas". Este depoimento sugere percepção visual apurada que, potencialmente, possibilitaria a esta respondente desenvolver qualquer tipo de projeto. Pressupõe, também, valorização do empenho para realização de trabalhos singulares, que se destaquem dos demais.

Por outro viés, a Respondente 24, também ex-aluna, comentando sua primeira apresentação na faculdade de design, mencionou diferença de desempenho entre os participantes do grupo. Segundo ela, "[...] era um capítulo do 'Capital', de Marx. Já achei mega difícil. Tinha uma menina tão travada no meu grupo, aí eu pensei: acho que essa menina nunca apresentou, na escola inteira dela. Ela travou num nível, que ninguém sabia o que fazer". Este segmento pressupõe que o ensino médio tradicional não prepararia seus estudantes para se apresentarem em plenário, atividade muito incentivada em escolas técnicas, surpreendendo a Respondente 24 , que, possivelmente, apresentaria grande desenvoltura quanto a isto. 
Ao relatar percebida diferença de aproveitamento entre seus colegas da graduação, esta Respondente 24 declarou que alguns, dos que haveriam cursado ensino médio em escolas particulares, apresentariam maior facilidade em certas aulas: "Às vezes, são pessoas mais cultas, que já leram mais coisas. [...] Nas aulas teóricas, as pessoas são mais desenvoltas, conversam mais da parte teórica, por exemplo, conhecem mais, leem mais". Note-se que alunos provenientes de determinadas escolas particulares de São Paulo ingressariam na graduação em design com bagagem teórica diferenciada. Isto sugere que conteúdos teóricos abordados nessas escolas apresentariam grau elevado de qualidade e abrangência, possibilitando a seus egressos se destacarem em discussões no âmbito do ensino superior. Sugere, ainda, que a abordagem teórica de escolas técnicas não se igualaria à de escolas particulares.

Por outro lado, tratando da disposição para o trabalho profissional, a mesma Respondente 24 informou se sentir mais preparada: "[...] insegurança em procurar emprego, eu não tive. Eu vejo meus amigos, agora, ainda tentando, fazendo estágio [na própria universidade] ${ }^{6}$, que é um pouco mais 'light', o trabalho não é tão pesado, a cobrança é diferente, a hierarquia também". Sua fala sugere que ex-alunos de cursos técnicos possivelmente apresentariam maior facilidade em relação ao ingresso no mercado profissional de design, em razão, talvez, de um processo de maturação iniciado há mais tempo, que os tornaria, eventualmente, mais atentos e amadurecidos em relação a oportunidades de mercado e a formas de inserção no mesmo.

De modo geral, egressos de cursos técnicos de comunicação visual em cursos universitários de design ou campos afins apontaram como percebidas diferenças entre alunos que, como eles, cursaram o ensino técnico de comunicação visual e seus colegas de classe, que não teriam esta formação: destreza em aplicativos gráficos, rigor visual, noções de história do design, percepção visual mais treinada, desembaraço em apresentações orais, maior determinação em relação ao ingresso no mercado de trabalho; como ponto negativo: menor bagagem teórica com relação a seus colegas oriundos de escolas particulares mais elitizadas.

\footnotetext{
${ }^{6}$ Trecho suprimido para evitar identificação da respondente.
} 


\subsubsection{2}

\section{Perspectivas de respondentes associados a escolas da rede Senac-SP}

A Respondente 36, ex-aluna, mencionou perceber diferença de desempenho entre ela própria e seus colegas, sobretudo no início do curso de graduação de design gráfico. Segundo ela, "Você tem uma vivência com os programas, então, quando o professor passava algum trabalho, você meio que já sabia qual caminho seguir. E os colegas, que não fizeram, eles ficavam muito perdidos, muitas vezes pediam ajuda p'ra gente". De modo bastante similar, a Respondente 38, outra ex-aluna, relatando sua própria experiência e a de colegas diante de propostas de projetos, declarou se sentir mais preparada, sobretudo no começo do ensino superior de design gráfico. Para ela, "Muita gente ficava perdida, não sabia como fazer. [...] como eu já tinha uma noção de software, era só eu pegar aquela ideia e executar, do meu jeito, no meu nível de conhecimento". Informou, também, que com o tempo, todo mundo foi se igualando. Estas declarações parecem indicar valorização, por parte de ex-alunos de cursos técnicos de comunicação visual, de suas próprias habilidades no adequado uso de ferramentas para encaminhar projetos propostos na graduação. Sugere, ainda, que egressos destes cursos levariam, em certa medida, vantagem em relação aos seus colegas de turma da faculdade.

Por sua vez, a Respondente 37, também ex-aluna, relatou que entrara um mês após o início do curso, devido à demora em sair sua bolsa de estudo. Naquele momento, a turma já teria visto a base dos programas Photoshop e Illustrator e estaria começando o InDesign. A este respeito, informou: "Foi muito tranquilo p'ra mim. Foi retornar, porque eu já tinha tido. Aí, o pessoal ficava perdido, o professor tinha que 'dá' mais atenção, a aula ia mais lenta. [...] Eu fiquei um pouco impaciente, porque queria ver coisas novas". Note-se que esta ex-aluna não apresentou qualquer dificuldade em acompanhar a turma, mesmo tendo ingressado na faculdade um mês após o início do semestre. Isto sugere que conhecimentos de ferramentas de egressos de cursos técnicos de comunicação visual possibilitariam melhor desempenho na execução de atividades propostas na graduação de design gráfico, em comparação aos demais alunos oriundos de ensinos médios tradicionais. 
Quanto aos resultados do primeiro exercício de projeto na graduação em design gráfico, um livreto de cerca de oito páginas, a mesma Respondente 37 comentou sua performance: "[...] eu senti bastante diferença, porque eu já conseguia usar outras ferramentas. Já tinha outra percepção visual, outras ideias do que eu queria fazer. O professor falou que meu livreto "tava melhor do que os trabalhos [...] do $4^{\circ}$, $5^{\circ}$ semestre". Sua fala sugere que, além de conhecimentos de ferramentas para execução de trabalhos, o Curso Técnico em Comunicação Visual haveria estimulado, ao menos nesta respondente, desenvolvimento de sua percepção visual, habilidade considerada no campo como relevante - e, ao mesmo tempo, mais difícil de ser desenvolvida -, por compreender processos cognitivos individuais e repertório prévio para interpretação mais sofisticada de relações semióticas.

Os dados apurados acima sugerem que determinadas habilidades desenvolvidas em cursos técnicos de comunicação visual do Senac-SP, tais como: adequado uso de ferramentas para encaminhamento de projetos e percepção visual mais treinada, seriam percebidas por egressos destes cursos, estando os mesmos em cursos universitários de design ou campos afins, como diferencial entre alunos que, como eles, cursaram o ensino técnico de comunicação visual e seus colegas de classe, que não teriam tal formação. 


\section{2}

\section{Resultados concernentes ao subproblema 2 (perfil dos professores)}

\subsection{1}

\section{Formação individual dos professores}

Os dados analisados na categoria temática apresentada nesta seção foram separados em subseções correspondentes às duas principais redes de escolas técnicas cobertas pela pesquisa: a Etec-SP e o Senac-SP.

\subsubsection{1}

\section{Perspectivas de respondentes associados a escolas da rede Etec-SP}

De acordo com a Respondente 1, professora, os docentes da Etec do Curso Técnico em Comunicação Visual seriam graduados, além de licenciatura, em um dos três eixos: artes plásticas/artes visuais; design (comunicação visual, desenho industrial, design gráfico, design de produto, design digital) ou comunicação social (jornalismo, publicidade, relações públicas). Exemplificou que a disciplina "Marketing e Criação Publicitária Aplicada ao Design Gráfico" seria ministrada por professores formados em jornalismo, publicidade ou relações públicas.

O Respondente 2, outro professor, informou que seria formado em artes plásticas, sendo ex-aluno do mesmo curso na própria escola e complementado seus estudos em design, bem como em psicopedagogia, "para melhor entendimento dos processos de aprendizado". Segundo ele, "[...] eu escolhi ser professor. [...] eu queria interagir com as pessoas p'ra que elas se descobrissem e não fossem os copistas da vida, mas que assumissem autonomia das suas ações, então é o que eu mais trabalho com eles". Afirmou achar importante obter algum feedback dos alunos a respeito de seu desempenho: "[...] tenho uma preocupação muito grande se a minha performance como professor é aquela que está à altura do que eles precisam". Tal declaração sugere intenção deste docente em contribuir para uma formação 
de qualidade, mostrando-se atento à necessidade de reajustes e aperfeiçoamentos em seus procedimentos didáticos.

Por seu turno, o Respondente 5, mencionando sua instrução, informou ter iniciado em artes gráficas. Para ele, "Eu sou técnico em artes gráficas, tecnólogo gráfico. Sou pós-graduado em processos de impressão, pós-graduado em design digital, pós-graduado em educação profissional e tecnológica. [...] Sou também licenciado em pedagogia". Sua fala parece indicar que ele apresentaria elevado grau de dedicação aos estudos, com foco em processos gráficos e design digital, bem como na educação profissional e tecnológica, área em que atuaria como docente.

Já o Respondente 6, outro professor, informou que se graduara em artes plásticas e que estaria no ensino técnico somente há três anos. Para ele, "Apesar de eu já dar aula há mais de 20 anos, no [ensino] técnico, eu sou professor recente. [...] A parte de design, eu procurei estudar bastante pela questão pedagógica e didática". Observe-se que este professor teria experiência na docência, buscando se informar a respeito do design quando começara a lecionar disciplinas relacionadas a esta área. Seu relato sugere entendimento de que os conteúdos e abordagens do design não se equivaleriam aos das artes plásticas.

Por sua vez, o Respondente 4, igualmente professor, declarou que sua formação seria em design mesmo: "O curso que eu fiz se chamava 'Artes com Ênfase em Computação Gráfica e Multimídia' e, depois, mudou p'ra ‘Design Digital'”. Informou que, desde 2004, vem se dedicando exclusivamente ao magistério: "Chegou um momento da vida que eu tive que trocar. As duas coisas não conseguiam coexistir dentro de mim. Eu tive que virar professor". Este trecho do seu depoimento sugere que as demandas de trabalho de um profissional de design seriam muito pesadas, sem horário determinado, dificultando sua conciliação com o magistério, que requer outro grau de dedicação.

Já a Respondente 3, outra professora, informou que se graduara em artes plásticas. Seria aposentada do Estado e não tencionaria, naquele momento, deixar de lecionar na Etec. A este respeito, mencionou que, na escola, haveria muitos professores na mesma situação. Para ela, "Se saírem todos, que tem uma determinada idade, 
uma experiência, [...], porque a gente tem uma experiência de louco. Este pessoal novo que "tá chegando [...] tem que estar, neste momento, trabalhando pareado conosco". Seu relato parece indicar preocupação da respondente não apenas com o emprego dos docentes mais antigos, mas, sobretudo, com a manutenção da presumida qualidade de ensino.

Observe-se que a maioria dos entrevistados teria formação em artes plásticas. Isto parece explicar o fato de que parte significativa dos conteúdos das disciplinas de cursos técnicos de comunicação visual apresentaria abordagens mais "artísticas", espontâneas, menos vinculadas a restrições técnicas de exercícios de projeto, mais características da área do design. Neste sentido, é notável que, com certa frequência, categorias conceituais e metodológicas do campo específico do design pareceriam ofuscadas por categorias mais afeta ao universo das artes plásticas.

\subsubsection{2}

\section{Perspectivas de respondentes associados a escolas da rede Senac-SP}

A Respondente 29, professora, declarou que se formara na área e na mesma rede de ensino que estaria lecionando. De acordo com ela, "Sou formada em design industrial pelo Centro Universitário Senac [afirmando com orgulho]. Acabei migrando p'r'o design gráfico. Não que eu não gostasse do industrial, foi mais por conta do mercado, foi mais fácil de entrar no gráfico". Sua visão pressupõe que vocações individuais para o design de produtos não estariam sendo plenamente aproveitadas por aqueles que terminaram a faculdade, fazendo com que jovens optem pelo design gráfico com base na dificuldade reputadamente maior de colocação profissional. Durante a graduação, esta respondente informou que haveria buscado estágio em escritório de design. Segundo ela, "Fui trabalhando, conciliando a faculdade junto com o trabalho. Fui efetivada. Mas no trabalho foi onde eu mais aprendi. [...] Eu trabalho atualmente, também, como freelancer". Esta passagem pressupõe que a prática profissional do design, em escritórios especializados, por exemplo, forneceria complemento, percebido como bastante relevante à formação de quadros docentes de design. 
Por sua vez, a Respondente 30, outra professora, mencionou que sua primeira formação seria em jornalismo. Para ela, "Dentro do jornalismo, eu trabalhava com áudio visual e me apaixonei por imagem. Era muito boa em diagramação. Aí, comecei a brincar com software gráfico. [...] D’aí, fui p’ra [graduação em] programação visual". Informou que teria cursado a disciplina "Semiótica do Cinema": "[...] aí, você tem a semiótica como parte da teoria da comunicação. Aí, vem a psicologia com a simbologia". Trabalhando com assessoria de imprensa, declarou sentir falta da abordagem da publicidade. Segundo ela, "Fui estudar publicidade e propaganda. Parei programação visual. Eu sou autodidata, vou me virar". O percurso de formação desta professora sugere mais afinidade com áreas relacionadas à comunicação visual do que com as de comunicação verbal. Acrescentou que, na época da faculdade de publicidade, teria iniciado um curso para se tornar agente de desenvolvimento ambiental: "Comecei a trabalhar já, dentro da sala de aula, [aqueles] princípios [ambientais e humanistas]". Esta fala sugere preocupação pessoal da docente quanto a influenciar seus alunos com relação a ideais, valores e ideologias, que consideraria meritórios.

O Respondente 31, também professor, declarou que se graduara em publicidade e propaganda, formação em marketing e negócios, sendo especialista em metodologia de design dentro de fundamentos "atitudes e valores", ser proativo, visão sistêmica, relacionamento, trabalho em equipe, atitude empreendedora. Com formação similar na graduação, a Respondente 32, outra professora, mencionou que se graduara em Publicidade, Propaganda e Criação. Para ela, “É por isso que eu fui p'ra essa área do design. Fui fazendo alguns cursos de aperfeiçoamento enquanto estava na graduação. [...] Fiz edição de vídeo, design impresso. Comecei pós-graduação em Comunicação Empresarial Institucional”. Recentemente, teria concluído outra pós-graduação em Arte e Educação. Tais depoimentos parecem indicar que graduados em publicidade e propaganda também poderiam apresentar afinidade pela área do design.

Com base nestes depoimentos, percebe-se que parte significativa dos professores teria formação em publicidade e propaganda, sugerindo que conteúdos de cursos técnicos de comunicação visual de escolas da rede Senac reaproveitariam, em parte e em certo sentido, conteúdos da área da publicidade e propaganda. $O$ fato de 
professores se empenharem no mercado de trabalho profissional do design sugere alinhamento ao programa pedagógico mais geral de escolas da rede Senac-SP, que valorizaria a inclusão de conteúdos mais estritamente vinculados à prática profissional.

\subsection{2}

\section{Perfil dos professores em relação às disciplinas lecionadas}

Os dados analisados na categoria temática apresentada nesta seção foram separados em subseções correspondentes às duas principais redes de escolas técnicas cobertas pela pesquisa: a Etec-SP e o Senac-SP.

\subsubsection{1}

\section{Perspectivas de respondentes associados a escolas da rede Etec-SP}

Como mencionado na seção 4.2.1.1, o Respondente 4, professor, seria formado em design digital. Comentando a respeito das disciplinas por ele ensinadas no Curso Técnico em Comunicação Visual daquela unidade da Etec, informou que seriam muitas: "Aqui, eu já lecionei várias: 'Aplicativos Informatizados em Design Gráfico', 'Concepção e Representação da Identidade Visual', 'Meios de Impressão e Processos Gráficos' e 'Produção Gráfica'. Como minha formação é em design, estas são as áreas que atuei". Esta declaração sugere alinhamento entre a formação deste professor com as disciplinas ministradas, todas especificamente da área do design gráfico.

Já o Respondente 6, professor graduado em artes plásticas, como apontado na seção 4.2.1.1, teria experiência na docência, buscando se informar a respeito do design quando começara a lecionar disciplinas relacionadas à área. Quanto a isto, informou que, no Curso Técnico em Comunicação Visual da Etec, seriam três: "Atualmente, é 'Desenho Geométrico'7. Já lecionei 'Formas Compositivas de Elementos Plásticos' e, agora, também estou com a disciplina de desenvolvimento de manual de identidade visual: desenvolvimento de logotipos, itens de papelaria".

\footnotetext{
${ }^{7} \mathrm{O}$ desenho geométrico faz parte da disciplina "Formas Expressivas Bidimensionais".
} 
Note-se que este docente seria responsável por uma disciplina com conteúdos mais diretamente afetos ao campo das artes plásticas ["Formas Compositivas de Elementos Plásticos"], outra mais relacionada ao design gráfico ["Concepção e Representação da Identidade Visual"] e, ainda outra, que compreenderia os dois universos ["Desenho Geométrico"]. Isto parece indicar que professores graduados em artes plásticas, ao serem alocados em disciplinas mais relacionadas ao design, caso não tenham vivência no mercado profissional da área, tenderão a suprir lacunas por meio de leituras complementares no novo campo de conhecimento.

Aspecto também mencionado na seção 4.2.1.1, o Respondente 5, teria formação em processos gráficos e design digital. Quanto à disciplina que lecionaria, comentou que, naquela unidade, seria apenas uma, do terceiro semestre: "Aqui, eu 'tô' com aplicativos informatizados ['Aplicativos Informatizados em Design Gráfico e Digital']. Em comunicação visual, acho que só". De acordo com ele, a proposta da disciplina seria: "Esta, do terceiro [módulo], é focada na produção de sites e animação 2D. São dois muito grandes: produção de conteúdo HTML, CSS, site e animação 2D". Seu depoimento sugere que a disciplina ministrada estaria em conformidade com sua formação. Pressupõe, ainda, que este docente seria capacitado para lecionar outras matérias oferecidas no curso de comunicação visual, tais como: "Meios de Impressão e Processos Gráficos" e "Produção Gráfica".

Já a Respondente 7 seria formada em área que não, exatamente, a da comunicação visual. Segundo ela, "A minha formação é publicidade e propaganda. Então, eu pego as disciplinas de software: [...] Illustrator, Photoshop e InDesign. Já peguei fotografia básica, no primeiro módulo, que é mais entender o conceito de foto analógica, foto digital e já peguei marketing". Note-se que esta respondente ministraria, entre outras, disciplina de software. Isto sugere que ela ficaria responsável por orientar os alunos a montar seus projetos nos aplicativos gráficos, isto é, a passar noções de projeto.

A Respondente 3, outra docente graduada em artes-plásticas, comentou que ministraria duas disciplinas: "Formas Expressivas Bidimensionais", oferecida em dois semestres (FEB I, que compreenderia exercícios empregando técnicas de nanquim aguado e lápis aquarelado; FEB II, que seriam desenhos de observação com guache TGA, aquarela e acrílica) e a outra seria "Formas Compositivas 
de Elementos Plásticos", em que se realizariam trabalhos de ponto e linha, abordando equilíbrio e simetria. Os dados sugerem que as duas disciplinas, uma com característica essencialmente plástica e outra envolvendo princípios de composição, estariam de acordo com sua formação. Sugere, uma vez mais, presença de categorias mais relacionadas ao universo das artes plásticas nestes cursos técnicos de comunicação visual.

Por sua vez, o Respondente 2, professor igualmente graduado em artes plásticas, mencionou que, naquele momento, lecionaria duas matérias: "[...] uma das minhas disciplinas é 'Influências dos Movimentos Artísticos na Comunicação Visual', querdizer, como que eles traduzem os elementos visuais para criar dentro da comunicação visual", que, segundo ele, seria oferecida nos três módulos, sendo uma das disciplinas de base, porque trabalharia aspectos conceituais. Isto sugere proposta de promover a ampliação de repertório. Quanto à outra disciplina, “[...] em 'Produção Gráfica', eu falo dos processos da fonte, da questão da ilustração, a questão de pré-impressão, impressão e pós-impressão p'ra eles entenderem qual é o processo de criação de uma revista [por exemplo] no aspecto físico". Esta passagem pressupõe mérito deste respondente, com formação em artes plásticas, de se inteirar a respeito de processos gráficos específicos da área do design gráfico para embasar projetos relacionados a este campo.

Como já comentado, parte significativa dos professores entrevistados seria formada em artes plásticas. Isto sugere preocupação quanto à possível presença de categorias conceituais e de abordagem mais subjetiva, menos afeta a restrições de projeto, em disciplinas da área do design.

\subsubsection{2}

\section{Perspectivas de respondentes associados a escolas da rede Senac-SP}

A Respondente 32, comentando a respeito do que lecionaria, informou participar de todas as unidades do curso. De acordo com ela, "No Senac, hoje em dia, não tem mais disciplinas. De comunicação visual, eu entro em todas as 'Qualificações Profissionais Técnicas', que são os antigos 'módulos'”. De maneira bastante similar, 
a Respondente 30 declarou se sentir preparada para ministrar qualquer segmento do curso. Segundo ela, "Eu posso ministrar o curso todo, dar todas as unidades curriculares, principalmente porque a gente reformatou. Antes, trabalhávamos em módulos". De acordo com estes depoimentos, parece que os docentes desta instituição apresentariam formação generalista do design, possibilitando, assim, lecionar diversos conteúdos do Curso.

De modo complementar, a Respondente 30 informou haver diversos perfis de professores. De acordo com ela, "Tem o perfil de professor mais p'ra software, professor mais p'ra mercado e eu, que fico com a parte teórica e dou a parte concreta. A parte de software, eu só complemento o reforço”. Similarmente, a Respondente 29 também declarou haver relação entre perfil do professor e aula ministrada. Segundo ela, "Na unidade, tem professor na área de design que vai p'ra comunicação. Como falar em público. Tem outro, que vai na área de marketing. Então, cada um tem um foco em alguma coisa". Tais declarações parecem indicar que o corpo docente desta unidade, embora tenha formação generalista, apresentaria preferências por determinados conteúdos e abordagens.

A Respondente 29, mencionando o conteúdo que ministraria, informou que no Curso Técnico em Comunicação Visual seria encarregada das aulas de aplicativos gráficos: "[...] eu leciono mais a parte de software: Photoshop, Illustrator, InDesign. [...] Eu, na parte técnica, estou mais na questão do software". Sua fala parece indicar que, nesta instituição, cada docente ficaria responsável por determinada abordagem de aula. Já o Respondente 31 declarou lecionar em diversas áreas. Segundo ele, "Eu leciono na área de comunicação, arte e design. Eu dou Photoshop, produção gráfica, toda parte de design institucional, fundamentos do design, embalagem, material de ponto de venda e infográfico. Se precisar, dou Illustrator e InDesign”. Este trecho de depoimento sugere que este professor teria uma formação mais abrangente e suas aulas seriam bastante voltadas à formação para o mercado de trabalho.

Por sua vez, a Respondente 30 comentou ser responsável pela parte mais conceitual: "Eu sou toda a parte de teoria, a história da arte, história da publicidade, história do design, história da ilustração. A parte de semiótica, simbologia, Gestalt, psicologia da forma, layout. Software gráficos, todos eu já dei aula". Esta passagem denota 
que os fundamentos teóricos, não apenas de design, mas de área afins, estariam a cargo desta respondente. Quanto a lecionar algum conteúdo específico, informou que não teria preferência. Para ela, "Eu gosto de dar aula. Não importa o assunto. Eu gosto é do ato de passar informação mesmo, com segurança. $O$ ato de professar: professor professa". Tal declaração sugere que as aulas ministradas por esta professora seriam bastante significativas, uma vez que, ao se identificar com a profissão, costuma-se exercê-la com competência.

Estes relatos sugerem diversidade do perfil dos professores em função da variedade de formação. Parcela menor de docentes ministraria conteúdos mais técnicos de aplicativos gráficos e algumas atividades, enquanto parte significativa de professores, com mais experiência didática e maior tempo de docência, ficaria encarregada de disciplinas cujos conteúdos e abordagens exigiriam formação mais abrangente e aprofundada.

\subsection{3}

\section{Envolvimento dos professores com o design}

Os dados analisados na categoria temática apresentada nesta seção foram separados em subseções correspondentes às duas principais redes de escolas técnicas cobertas pela pesquisa: a Etec-SP e o Senac-SP.

\subsubsection{1}

\section{Perspectivas de respondentes associados a escolas da rede Etec-SP}

Como citado no item 4.2.1.1, a maioria dos professores entrevistados teria formação em artes plásticas, não apresentando, assim, envolvimento mais próximo ao design. O Respondente 2, apesar disto, declarou haver complementado seus estudos em design para melhor adequar-se à proposta do curso. Para ele, "Nós ainda não temos história do design, então, a história do design tem que ser puxada p'ra história das artes visuais, das artes plásticas e eles fazem as conexões [disciplina 'Influências dos Movimentos Artísticos na Comunicação Visual']". Esta passagem sugere mérito 
deste professor em proporcionar conteúdos de história do design na disciplina de história da arte, uma vez que o curso seria de comunicação visual. Pressupõe, também, a conveniência de se incorporar a disciplina de história do design à grade curricular de cursos técnicos de comunicação visual desta rede de ensino.

O Respondente 6, outro professor com formação em artes plásticas, como visto na seção 4.2.2.1, apesar de ministrar aulas por mais de 20 anos, lecionaria há apenas três no ensino técnico, quando buscou se atualizar. Declarou que trabalharia mais com ilustração do que design em si: "[...] profissionalmente, já desenvolvi logotipos, mascotes p'ra empresas, mas é mais voltado realmente p'ra ilustração". Quanto a isto, declarou acreditar no alinhamento da ilustração com o design. Segundo ele, "[...] às vezes, uma determinada ilustração você tem que passar um determinado clima: mais alegre ou mais sério, mais jovial ou mais frio, melancólico". De acordo com este respondente, em comum, entre o design e a ilustração, haveria o emprego das cores, composição, maneira como se daria o destaque entre figuras para determinar a intenção da mensagem. Este relato sugere, na percepção de docentes com formação em artes plásticas, maior grau de superposição entre o universo das artes plásticas e o universo do design. Isto talvez explique certa prevalência de categorias conceituais e metodológicas das artes plásticas no magistério do design gráfico no âmbito do ensino técnico.

Já o Respondente 4 informou haver trabalhado profissionalmente como designer, base de seu conhecimento sobre os principais aplicativos gráficos, técnicas de ilustração digital e métodos de trabalho, desde 2004 dedicando-se exclusivamente ao magistério. Segundo ele, "Minha linha de trabalho é mais design alternativo mesmo, a contracultura, culturas juvenis. Como que o jovem interage com a cultura, o jovem com a cidade, como ocorre essas interações, como o jovem trabalha hoje. As negociações que ocorrem". Esta declaração parece indicar que este respondente apresentaria familiaridade com a atividade profissional do design. Além disto, os trechos grifados sugerem presença de componentes, de certo modo, ideológicos em sua fala, identificando-o com uma visão presumivelmente mais crítica da sociedade de consumo, buscando incentivar seus alunos a refletirem segundo esta orientação menos conformada a uma visão de mundo mais burguesa. 
Como já mencionado, é notável a presença de categorias conceituais mais relacionadas ao universo das artes plásticas no curso, possivelmente em razão da majoritária formação dos respondentes nesta área. Apesar disto, é perceptível a preocupação de parte dos docentes em adaptar conteúdos das artes plásticas para a área do design, bem como sua atenção quanto à interação dos jovens no âmbito cultural, social e profissional.

\subsubsection{2}

\section{Perspectivas de respondentes associados a escolas da rede Senac-SP}

Como visto na seção 4.2.1.2, a Respondente 29 graduara-se na área: "Sou formada em design industrial [...]. Acabei migrando p'r'o design gráfico. Não que eu não gostasse do industrial, foi mais por conta do mercado, foi mais fácil de entrar no gráfico". Este trecho do seu depoimento sugere que o design gráfico tenderia a atrair mais jovens do que o design de produtos, por conta da considerada maior dificuldade de colocação no mercado de trabalho. Ainda, a mesma Respondente 29 informou que haveria começado a trabalhar em design como estagiária. Segundo ela, "Fui trabalhando, conciliando a faculdade junto com o trabalho. Fui efetivada. Mas no trabalho, foi onde eu mais aprendi. [...] Eu trabalho atualmente, também, como freelancer". Sua fala sugere que demandas de um escritório de design haveriam fornecido complemento, percebido como bastante significativo para seu aprimoramento profissional e posterior atuação na docência em cursos técnicos de design, alinhando-se ao programa pedagógico mais geral de escolas da rede Senac-SP, que valorizaria abordagens mais especificamente relacionadas à prática de mercado.

A Respondente 30, comentando alguns trabalhos realizados, declarou estar sempre exercendo a atividade do design. Para ela, "Faço todos os cartazes de divulgação, material de propaganda dos meus cursos, das coisas que eu amparo. Cenografia, design de moda, entra no figurino. [...] Editando vídeo, fazendo material áudio visual, lettering, filme, ilustração". Este relato parece indicar que o campo de atuação desta respondente ultrapassaria os limites do design, envolvendo uma área criativa bastante ampla. Além disto, informou incorporar trabalhos de alunos aos seus. Segundo ela, "[...] pegando até [trabalhos] dos próprios alunos. Aí, a gente coloca 
como coautoria. [...] E eu boto na rua os trabalhos deles". Sua fala sugere mérito em valorizar trabalhos de quem estaria iniciando na área, possibilitando contribuir com a autoestima e para desenvolvimento de competências próprias do campo.

O Respondente 31, como citado no item 4.2.1.2, seria graduado em publicidade e propaganda e trabalharia em agência de publicidade. Em marketing, faria os materiais de comunicação interna. De modo complementar, a Respondente 32 também declarou ter trabalhado profissionalmente na área do design gráfico. Para ela, "Eu tenho um curso de complementação em design impresso. [...] Eu trabalhei em uma agência com a parte de design gráfico e estagiária em lugares que eu fazia a parte de design gráfico também". Note-se que, nos dois casos citados, haveria contato com a prática profissional do design gráfico. Isto sugere que tais vivências, em certa medida, teriam colaborado para o desenvolvimento de competências próprias da área e para a docência em cursos técnicos de comunicação visual.

A mesma Respondente 32 informou a percebida importância da docência em design. Para ela, "Eu não tenho formação. Mas com certeza absoluta, o que mais me ensinou no mundo do design foi dar aula. Porque eu corri atrás, fiz curso de complementação, eu li muita bibliografia e eu experimentei o que funcionou e o que não funcionou". Sua fala parece indicar que as demandas de uma sala de aula possibilitariam ao verdadeiro professor comprometer-se com a própria formação. Além disto, citou como bastante relevante o que aprendera com colegas de profissão: "Uma das coisas que mais me ensinou foi o convívio com outros professores. [...] Coisas que eu não sabia, que eu lia e não entendia, eu entendia com eles. E eu dou muito valor ao aprendizado com outra pessoa". Este trecho sugere que um indivíduo, buscando constantemente se atualizar e procurando a melhor estratégia para passar e construir conhecimento com seus alunos, teria muito apreço por quem fizesse o mesmo por ele.

Os dados examinados acima pressupõe que o corpo docente do Senac-SP, ao menos o das unidades pesquisadas, seria formado por profissionais com prática de mercado, sobretudo da área do design, da publicidade/propaganda e do marketing. Sugere, também, que a troca de conhecimento entre colegas, cada qual com sua especialidade, poderia contribuir com a formação mais plural de todos, o que, potencialmente, melhoraria a performance em sala de aula. 


\section{3}

\section{Resultados concernentes ao subproblema 3} (estruturas materiais e físicas)

Os dados analisados na categoria temática apresentada nesta seção foram agregados, inicialmente: com as respostas sobre os aspectos mais gerais das estruturas materiais e físicas (4.3.1) com as respostas relativas, especialmente, aos espaços dos laboratórios de informática (4.3.2). Por sua vez, no interior de cada uma destas duas subseções produzidas, separaram-se os dados analisados em subseções correspondentes às duas principais redes de escolas técnicas cobertas pela pesquisa: a Etec-SP (4.3.1.1 e 4.3.2.1) e o Senac-SP (4.3.1.2 e 4.3.2.2).

\subsection{1}

\section{Aspectos mais gerais das estruturas materiais e físicas}

\subsubsection{1}

\section{Perspectivas de respondentes associados a escolas da rede Etec-SP}

Uma das escolas pesquisadas, a Etec Carlos de Campos, composta por dois edifícios, situa-se no bairro do Brás (Figura 1). A inauguração do edifício principal data do início da década de 1930, época em que foram determinadas as primeiras escolas destinadas à formação de mestres para o ensino profissional.

Segundo Carvalho (2017, p. 19): "Foram os cursos de aperfeiçoamento, instalados nas Escolas Normais de Artes e Ofícios da Capital - Masculina e Feminina.

Esse curso de aperfeiçoamento para educação profissional feminina aconteceu no edifício recém-inaugurado, no Brás", revelando-se a tradição dessa escola no ensino técnico profissional na cidade de São Paulo.

Ao comentar a respeito da estrutura física de sua escola do curso técnico, o Respondente 26, ex-aluno, informou considerar o edifício antigo mais conveniente. Para ele, "[...] era notável que o prédio velho era mais confortável. A gente tinha aula 
de FEB ${ }^{8}$ naquelas salas, tinha bastante espaço disponível p'ra poder se movimentar, se reposicionar p'ra 'tê' aula, o que seria inviável no prédio novo, porque as salas são bem menores". Esta declaração aponta para maior adequação de aulas percebidas como mais dinâmicas em salas do edifício antigo. Os corredores desta construção também seriam utilizados para exposição de trabalhos de alunos (Figura 2 e 3).

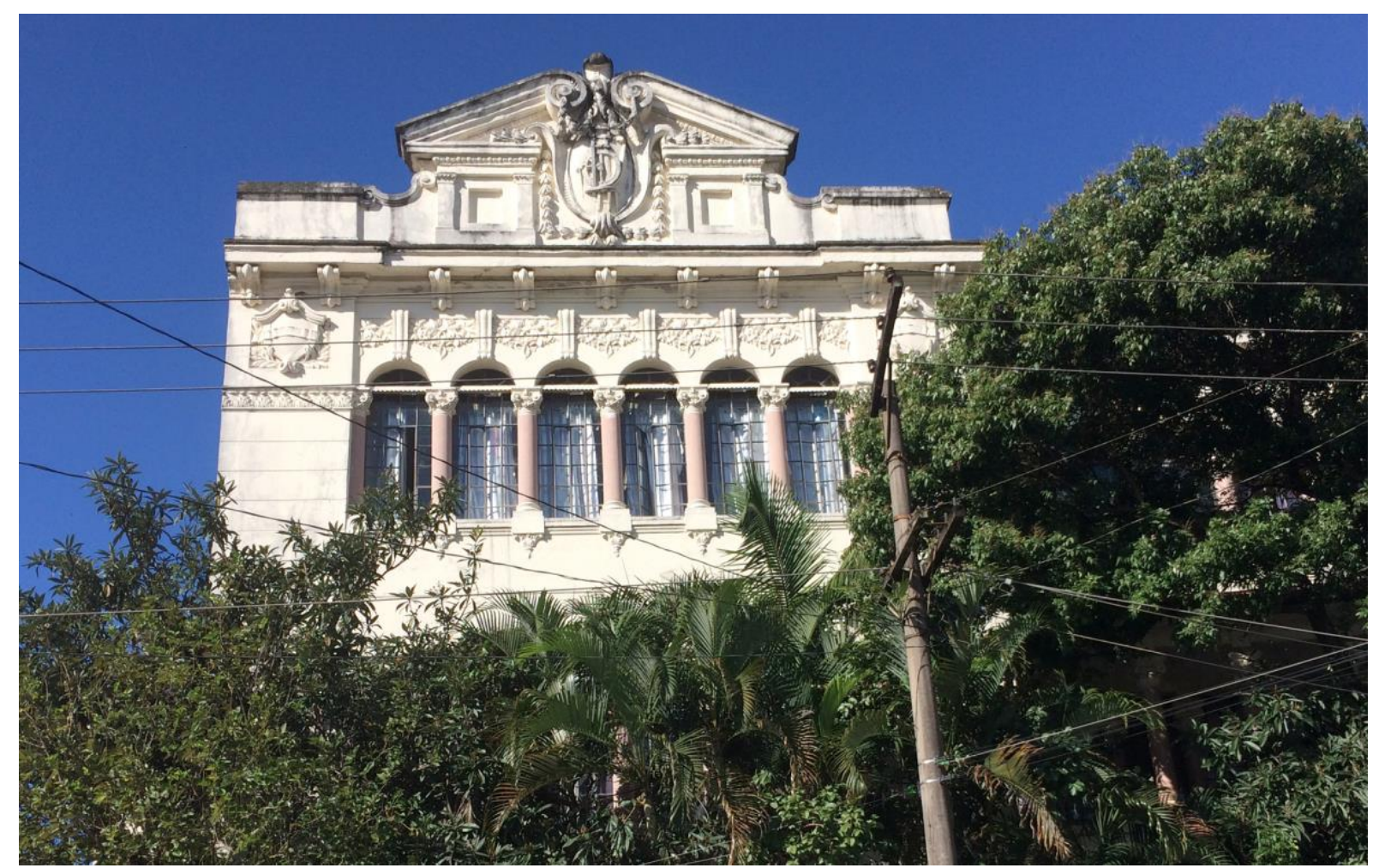

Figura 1:

fachada Etec Carlos de Campos

Por sua vez, a Respondente 23, também ex-aluna, comentando sua impressão quanto aos materiais e espaços disponíveis em sua antiga escola, declarou considerá-los satisfatórios. Para ela, "A infraestrutura era boa, tinha mesa de luz, banheiros sempre limpos, sempre tinha água. A limpeza geral do ambiente era boa. Eu não lembro de muitos espaços de convivência que não fosse o pátio. Tinha oficina p'ra aula de serigrafia". Seu relato parece indicar que as estruturas físicas e materiais, além da questão da limpeza, seriam adequadas a diversas práticas pedagógicas. Ainda quanto a aspectos mais gerais da estrutura física, a mesma Respondente 23 declarou preferência pelo prédio original da escola. Para ela,

\footnotetext{
${ }^{8}$ FEB - Formas Expressivas Bidimensionais
} 
"O prédio antigo é lindo, muito arejado, as janelas são superaltas, entra muita luz. Era um ambiente muito gostoso. O prédio novo é muito feio". Sua fala revela que quando houve, em algum momento, a ampliação dessa escola, a construção mais nova não teria seguido o estilo arquitetônico do prédio original, não agradando a essa respondente. Isto talvez se deva ao fato de que construções percebidas como mais "básicas" seriam menos dispendiosas.

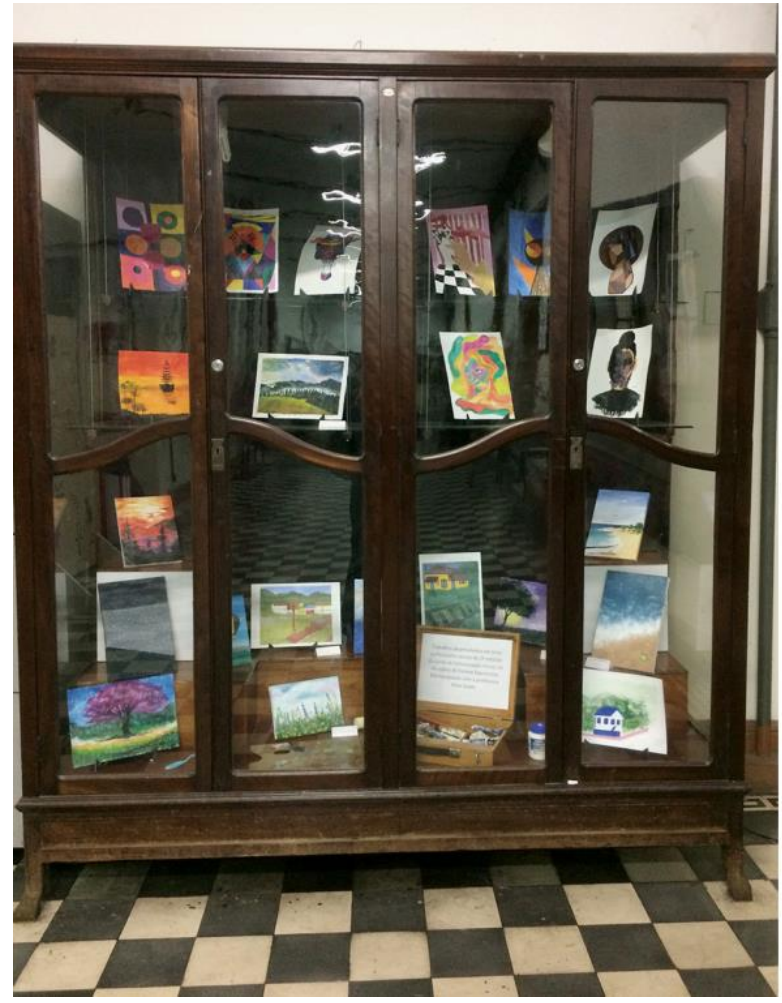

Figura 2:

mobília para expor trabalhos de alunos

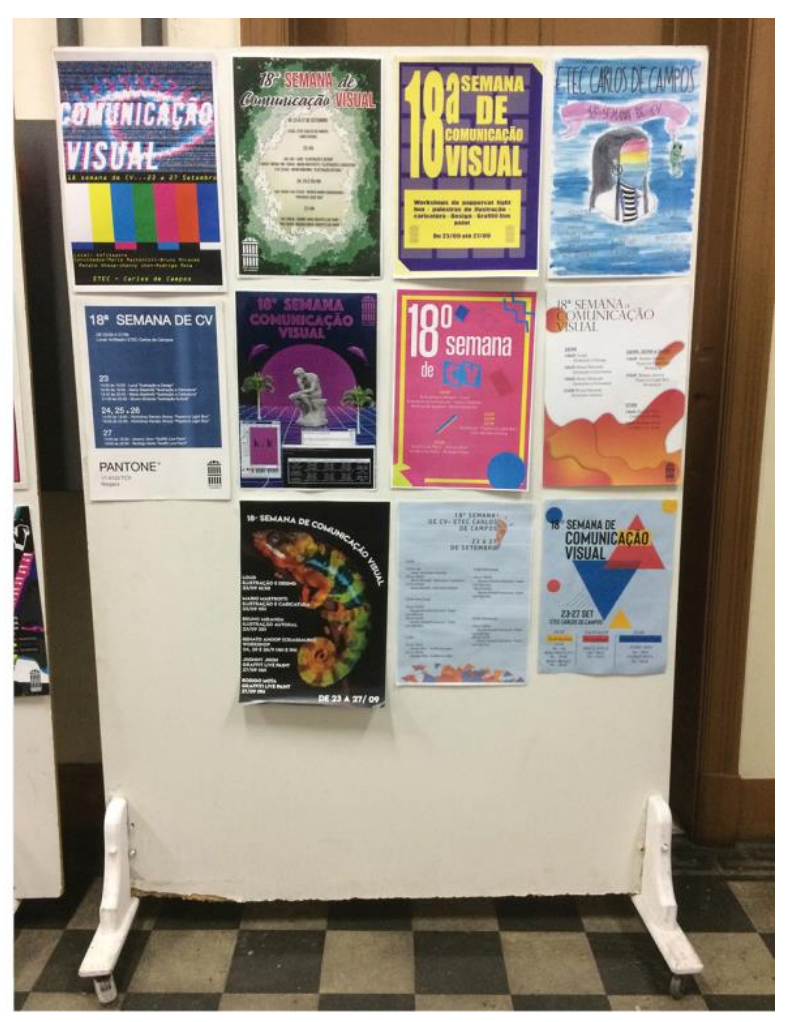

Figura 3:

suporte para expor trabalhos de alunos

A quadra poliesportiva localiza-se incrustrada no centro do edifício antigo (Figura 4) e, possivelmente por ser a única da escola, seria altamente disputada, sobretudo por alunos do Etim. Ao lado, encontra-se a área da cantina, cobrindo toda a extensão da quadra (Figura 5), que seria destinada a refeições dos alunos do Etim, possuindo três fileiras de mesas com banquinhos e sendo bastante frequentada, especialmente no intervalo das aulas. Para o já citado Respondente 26: "Na minha época, o pátio era inteiro livre, e tinha bancos só no perímetro desse pátio. A gente ficava nesses bancos sentados ou mesmo lá nos corredores". Note-se que parte dos alunos ali ficaria para, além de fazer suas refeições ou um lanche rápido, também conversar, 
fazer uma tarefa escolar ou apenas esperar o início da aula, talvez se devendo ao fato de que seria um dos poucos espaços de convivência da escola.

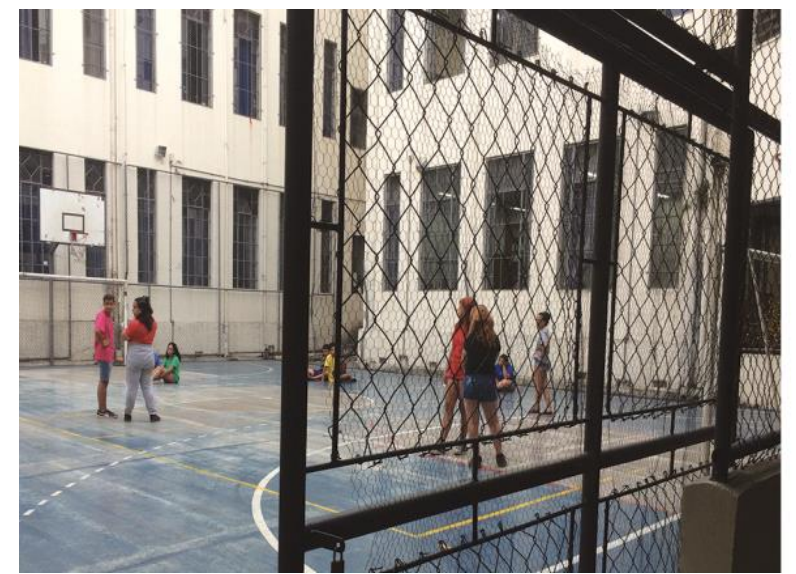

Figura 4:

quadra poliesportiva

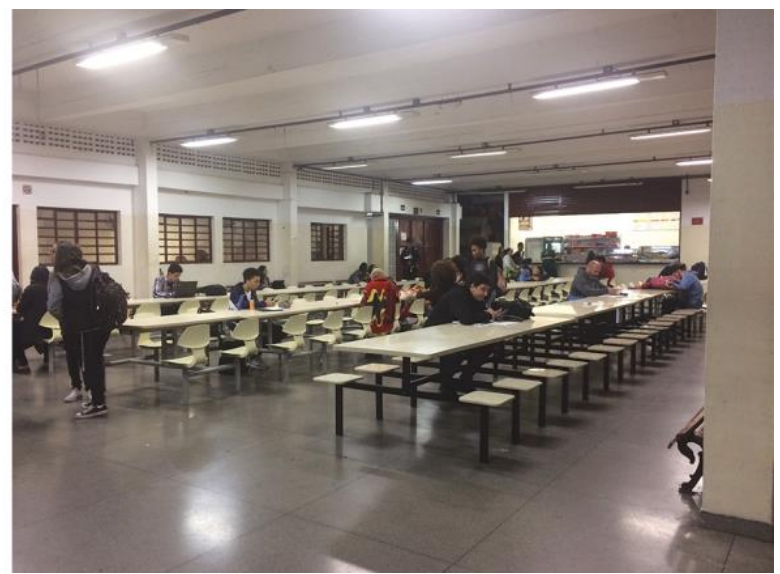

Figura 5:

espaço de convivência e cantina

Ao lado da cantina encontra-se o laboratório multiuso, que, segundo depoimentos informais, seria o espaço reservado para dois grupos de disciplinas: "Formas Compositivas de Elementos Plásticos" e "Meios de Impressão e Processos Gráficos" (Figura 6). Tal espaço, além de mesas e banquinhos, possuiria um tanque, mesa de luz, tábua de estampar, além de uma salinha para sensibilizar telas de impressão (Figura 7). As aulas em laboratórios, segundo o mesmo Respondente 26, "[...] eram essenciais porque a gente mexia com tinta, precisa ter um tanque p'ra lavar os pincéis etc. [...] E a disposição em sala de aula, com vários estudantes na mesma mesa era muito bom, porque a gente conseguia trocar bastante informações". Sua fala parece indicar atenção em disponibilizar espaços para desenvolvimento de atividades com características mais empíricas, de "mão na massa". Sugere, ainda, adequação de sua configuração, facilitando a socialização e o aprendizado.

A biblioteca é um espaço adequadamente iluminado, que oferece mesas de estudo, computadores e alguns livros relacionados à área da comunicação visual (Figura 8), havendo alguns de arte e, em menor quantidade, de design - com destaque para o único volume de "História do Design Gráfico", de Philip Meggs (Figura 9). Segundo o Respondente 26, já citado, "A biblioteca a gente nunca usou. Não lembro de ser instruído a usar a biblioteca no curso, nem de ter sido levado p'ra lá por algum professor". Observe-se que este ex-aluno seria do curso não vinculado ao ensino 
médio, o que sugere que não haveria incentivo à pesquisa, seja pelo encurtamento do tempo, seja pelo caráter mais prático do ensino técnico de comunicação visual, pressupondo-se, no entanto, que os alunos do Etim desfrutariam mais deste espaço para pesquisas.

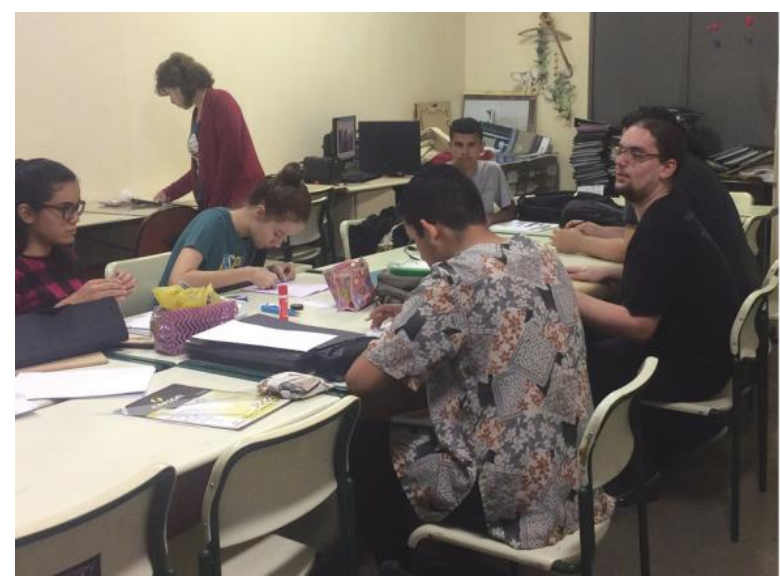

Figura 6:

oficina multiuso

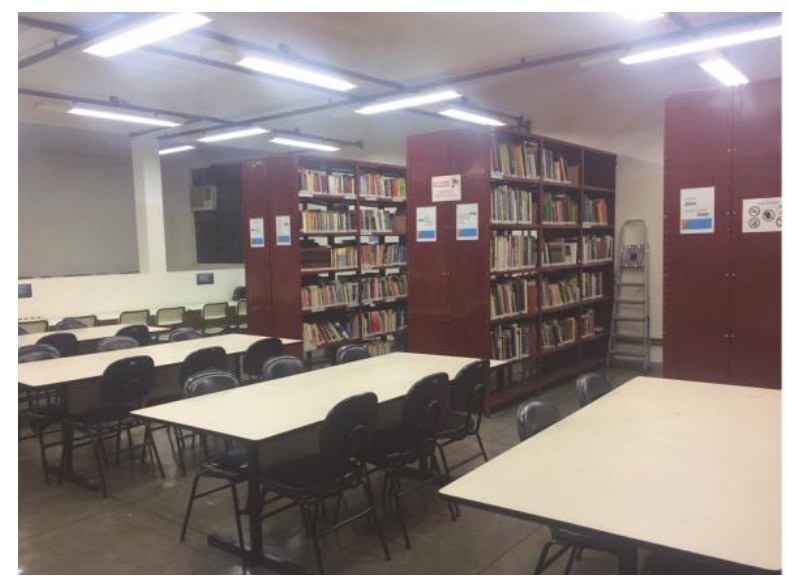

Figura 8:

biblioteca

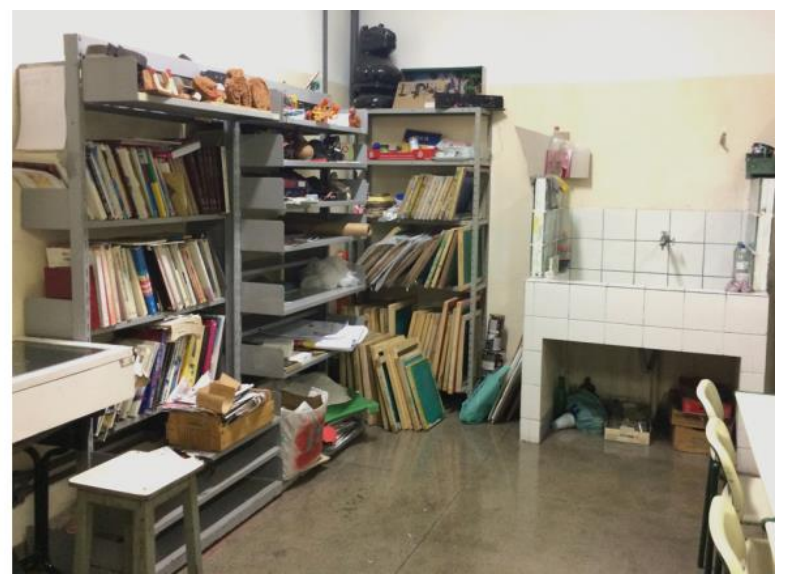

Figura 7:

oficina multiuso

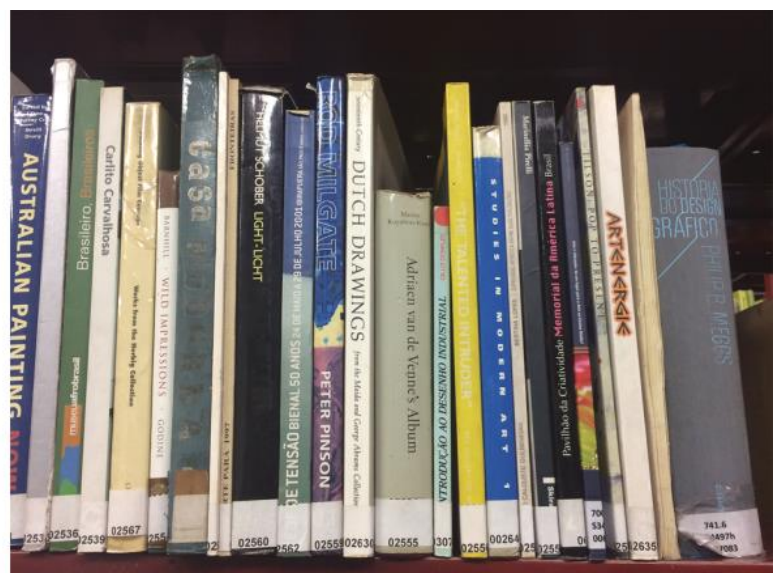

Figura 9:

livros relacionados às artes plásticas e ao design

Quanto a outros espaços disponíveis em sua unidade escolar da rede Etec,

a Respondente 28, ex-aluna, declarou que: "Tinha o laboratório de estamparia que, também, tinha aula de moda. Era onde a gente fazia 'silk' [silk screen]. Era tudo muito novo, muito limpo. Era pia, mesas com banquinhos, tábuas de estampar. Tinha estrutura p'ra dar aula também". Este trecho do seu depoimento revela existência de laboratório multiuso, utilizado por mais de um curso. Sugere, ainda, que tal espaço seria equipado visando atender diversificadas demandas pedagógicas. 
Comentando sua percepção geral quanto às demais áreas da escola, a mesma Respondente 28 informou achá-las bastante boas. Para ela, "A 'infra' da Etec era bem 'maneira'. Lá era novo, as coisas eram novas. O espaço, 'tipo' quadra, pátio, eram bem grandes. O anfiteatro era muito 'maneiro'. As salas em si eram bem limpas. A sala de desenho eram muito 'show'". Sua declaração parece indicar que as estruturas materiais e físicas dessa escola da rede Etec seriam convenientes para o aprendizado da comunicação visual, possivelmente por se tratar de uma unidade relativamente nova.

A Respondente 1, professora, comentando a respeito das aulas de desenho geométrico, informou que haveria estrutura material e física adequada para atividades desta disciplina. Segundo ela, "[...] desenho geométrico tem apostilinha e [o aluno] vai repetindo. Ele vai compondo uma apostila também. Ele vai p'ra prancheta, o professor pega a lousa verde, faz a forma com compasso de lousa e, no final, ele monta, também o manualzinho". Este trecho do seu depoimento sugere que haveria nessa unidade escolar salas de aula com suportes adequados, como pranchetas, além de quadro negro e compasso de lousa que possibilitariam desenvolvimento de atividades relacionadas, por exemplo, a disciplinas mais técnicas de desenho.

Por sua vez, a Respondente 27, ex-aluna, informou que haveria duas construções distintas na unidade da Etec que frequentou. De acordo com ela, "Tem o prédio principal e um corredorzinho que tem um espaço que é o auditório e mais três salas de serviço. Uma tem mesas grandes inclináveis. Do lado, tem uma sala com bancadas de concreto p'ra aula de desenho e de pintura (Figura 10)". Esta passagem sugere existência de espaços físicos e materiais adequados para a prática de atividades mais empíricas, de "mão na massa", características da área das artes plásticas. Ainda, a mesma Respondente 27 informou que haveria outras dependências: "Do lado, tinha uma sala que tinha um fundo infinito e uma outra porta que dava p'ra uma sala escura p'ra revelar foto, mas que a gente nunca usou. As luzes não funcionavam. [...] Um lugar abandonado na escola total". Note-se que haveria salas não utilizadas nesta escola, sugerindo que alguns espaços ociosos poderiam ser aproveitados para algum tipo de atividade pedagógica. 


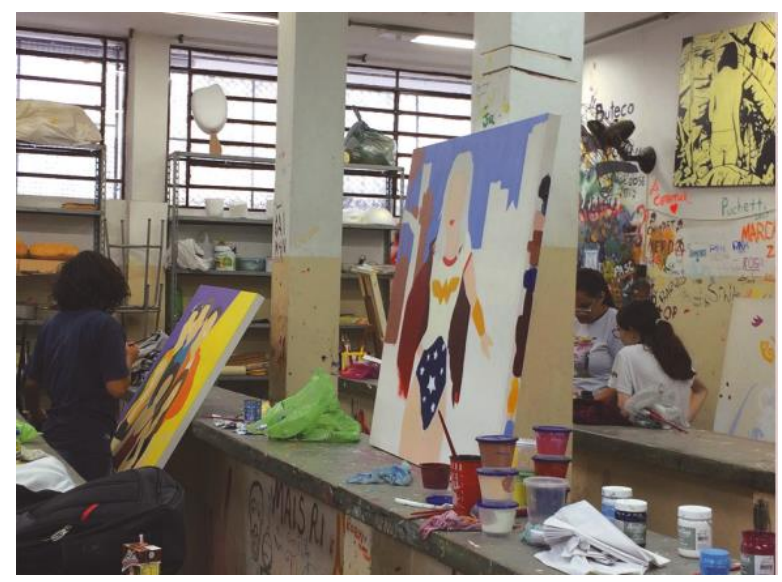

Figura 10:

ateliê de desenho e pintura

Já a Respondente 24, ex-aluna, apontou, como especial, o fato de ter um lugar próprio para seus pertences. De acordo com ela, "Fiquei empolgada porque tinha armário lá, tipo escola americana". Sua fala pressupõe mérito da instituição em disponibilizar, a seus alunos, um espaço para armazenamento de seus materiais escolares. Relatando outras estruturas materiais e físicas, a mesma Respondente 24 informou que haveria salas específicas para determinadas atividades. Segundo ela, "Tinha sala com mesas largas p'ra desenho. [...] Tinha sala de projeção p'r'as aulas de artes visuais e salas com TV. Espaço físico ótimo". Seu relato sugere existência de materiais e estrutura física nesta unidade para adequado desenvolvimento de diversas propostas. Pressupõe, ainda, ênfase em atividades relacionadas às artes plásticas, nem sempre em correspondência ao universo do design.

A Respondente 25, igualmente ex-aluna, lembrando alguns espaços de sua escola, comentou que haveria alguns reservados a atividades próprias. Segundo ela, "Tinha sala de pintura, onde a gente fazia aula de cor, que era p'ra gente poder pintar mesmo. Tinha uma mesa de luz, uma salinha de fotografia, com fundo falso, uns aparelhos de iluminação" (Figura 11 e 12). Novamente, de acordo com tal declaração, o fato de haver um espaço reservado para o estudo prático da cor revela a ênfase do curso em abordagens mais empíricas, relacionadas ao campo das artes plásticas. 


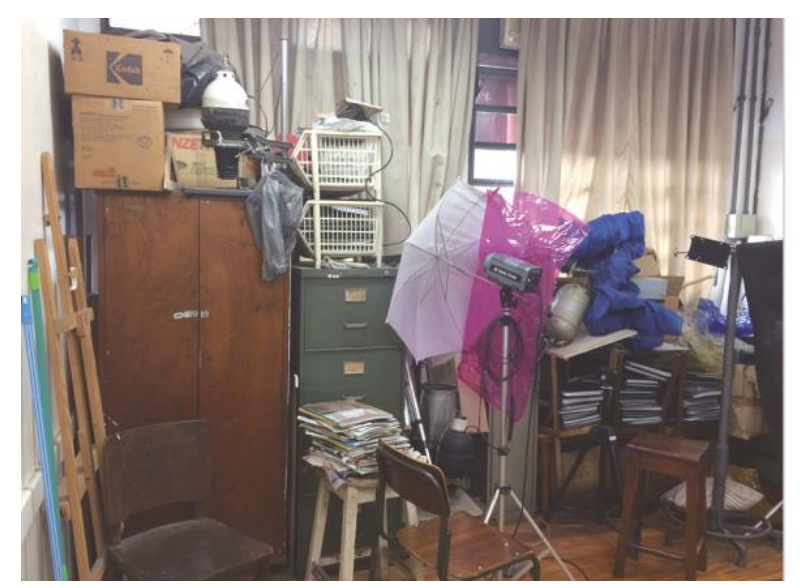

Figura 11:

estúdio de fotografia

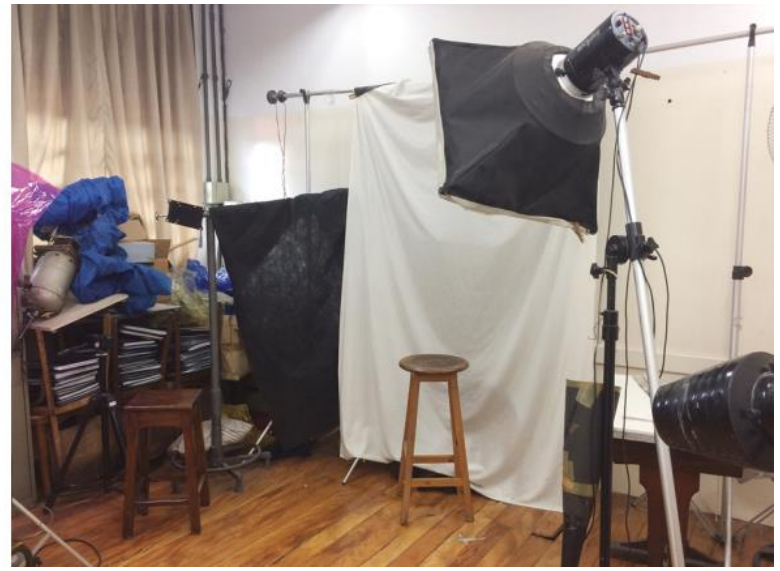

Figura 12:

estúdio de fotografia

Por seu turno, o Respondente 26, ex-aluno, comentando sua percepção quanto às aulas de fotografia, informou que teria uma sala própria para aulas expositivas e que haveria outra dependência anexa para a parte mais prática. Segundo ele: "Usava pouco o estúdio nos fundos. Equipamento de fotografia era uma coisa que a gente não tinha muito lá. Tinham duas câmeras para uma turma de 20 alunos. A gente tinha que revezar p'ra tirar foto". Sua fala revela que haveria poucas aulas práticas de estúdio e que os materiais disponíveis para fotografia não seriam suficientes para a quantidade de alunos.

Relatando o processo de impressão dos trabalhos, o mesmo Respondente 26 declarou considerar que seria excessivamente dispendioso para os alunos. Segundo ele, "A gente não tinha estrutura de impressão p'r'os trabalhos, tinha um gasto enorme com impressão em gráfica. [...] E nunca se pensou alguma estratégia p'ra imprimir trabalhos de alunos. Não existe verba p'r'os cursos técnicos que venha do Estado". Este comentário lança luz à necessidade de se buscar meios para não sobrecarregar, financeiramente, os alunos de cursos técnicos com custos de impressão de trabalhos, uma vez que a entrega dos mesmos seria obrigatória para todos.

De outro ponto de vista, a Respondente 27, ex-aluna já citada, relatando determinadas vivências não educacionais na Etec em que estudou, declarou que teriam sido perturbadoras. Segundo ela, "[...] minha 1a experiência na escola foi alagamento. A gente ficou ilhada na escola. No $2^{\circ}$ ano choveu dentro e molhou todos os armários. [...] Eram os próprios alunos empurrando os armários, [...] 
pegando rodo p'ra tirar a água de dentro das salas". Esta declaração revela, a princípio, que a estrutura física dessa instituição não suportaria chuvas intensas e sugere, ainda, ausência de funcionários para dar apoio em tais situações. Relativo a outras dependências, a mesma Respondente 27 informou considerá-las precárias. Para ela, "A biblioteca é pequena, ninguém usa ela direito. Na enchente, caiu o teto. A gente reclamava da estrutura da nossa escola. A direção falava que dependiam do Centro Paula Souza, que falou que não tinha muito o que fazer. [...] Foi meio que largada". Com base em seu depoimento, parece que não estaria havendo investimento suficiente em algumas unidades da rede de Etecs no âmbito estrutural e de pessoal de serviço.

A mesma Respondente 27, ao relatar sua percepção quanto a aulas essencialmente teóricas, mencionou acreditar que parte delas deveria ter abordagem mais prática. De acordo com ela, "Não é uma aula que te prende. E, quando você tem 14, 15 anos, você quer fazer. Em MIPG (Meios de Impressão e Processos Gráficos), só teve teoria e eram umas aulas meio repetitivas, não tinha material, não tinha estrutura, como uma oficina". Esta declaração pressupõe ausência de estruturas materiais e físicas apropriadas ao estudo de uma disciplina com característica, ao que se presume, especialmente prática, o que tenderia a comprometer, em certa medida, o aprendizado.

Ainda a mesma Respondente 27, comparando as aulas de serigrafia na graduação e no curso técnico, informou perceber grande diferença entre elas. Segundo ela, no curso técnico, "[...] era mais teoria, porque não tinha como dar a prática. [...] Minha professora mostrou uns vídeos. [...] Eu não fazia a mínima ideia como a tinta passava por um lado e não passava por outro, sendo que era a mesma tela". Note-se que, nas aulas de serigrafia no curso técnico, a restrição a conteúdos teóricos e apresentações de vídeos a respeito desta determinada técnica sugere que não haveria estrutura física nem mesmo material para aulas práticas de processos de impressão. Pressupõe, ainda, necessidade de proporcionar aos alunos vivências dos diversos processos de impressão em cursos técnicos de comunicação visual.

O Respondente 26, ex-aluno já citado, comentando que seria do período diurno, apontou problemas em determinadas aulas devido à claridade das salas. Para ele: 
"[...] era muito difícil 'tê' aula expositiva por conta do sol. Então, o professor fechava a cortina, mas não era suficiente p'ra poder ter imagens adequadas no slide. [...] Isso quando a sala não 'tava muito quente, [...] acontecia também, no verão, pelo menos". Sua declaração parece indicar ausência de verbas das escolas da rede Etec para adquirir cortinas que possibilitariam diminuir o excesso de luminosidade ou, ainda, que as salas do prédio antigo não seriam as mais indicadas para aulas expositivas.

De modo muito similar, o Respondente 2, professor, relatou situações que, às vezes, não permitiriam sua atuação da maneira que gostaria. Segundo ele, "[...] eu venho dar aula e tenho que fazer projeção e tem uma cortina que não cobre. [...] Então, eu falo com a direção, a direção não tem como mudar, então fica bem difícil. Aí, eu fico fazendo mil situações p'ra conseguir as melhores condições p'ra eles". Este segmento aponta, como mencionado anteriormente, para a falta de itens básicos, como cortinas adequadas que permitissem projeção satisfatória e, também, para necessidade de assistência financeira para minimizar tais situações.

O Respondente 4, professor já mencionado, referente a possíveis melhorias, declarou considerar conveniente adequar a estrutura: "[...] ter mais espaço, eu poderia falar da escola como um todo, a gente precisaria de um espaço maior aqui p'ra o aluno ter uma vivência melhor aqui". Esta passagem pressupõe que ampliar os espaços físicos, como salas, laboratórios, quadras de esporte, pátios, entre outros, poderia contribuir para vivências mais significativas.

Os dados examinados acima referentes a estruturas materiais e físicas de escolas da rede Etec parecem indicar que, em comum, todas possuiriam salas mobiliadas com mesas ou pranchetas destinadas a aulas de desenho e pintura. Ainda, poucas unidades apresentariam estúdio de fotografia e quantidade suficiente de equipamentos para a adequada prática da fotografia. Do mesmo modo, nem todas as escolas estudadas possuiriam oficinas destinadas ao estudo de meios de impressão, como, por exemplo, a serigrafia. Outro ponto abordado seria a falta de estrutura material ou de recursos para viabilizar impressões dos trabalhos executados por alunos. Casos isolados, nem por isto menos preocupantes, como alagamentos e falta de funcionários, parecem revelar que determinadas unidades escolares não estariam sendo assistidas devidamente. Os aspectos mencionados 
parecem influenciar, em certa medida, a dinâmica de aula e o aprendizado. Ainda, como sugestão apontada, mais espaço físico - como pátios, por exemplo possibilitaria uma melhor convivência social.

\subsubsection{2}

\section{Perspectivas de respondentes associadas a escolas da rede Senac-SP}

Outra unidade escolar mais especialmente pesquisada neste estudo foi o Senac Largo Treze, localizado no bairro de Santo Amaro, que se trata de um edifício relativamente novo, de linhas retas (Figura 13). Dentro do edifício, após passar por uma sala de recepção, à direita, localiza-se um dos laboratórios de informática com computadores PC, bastante amplo, adequado para aulas. Seguindo o corredor, há uma biblioteca, com mesas e computadores para uso geral, sendo constatada a presença de livros da área (Figura 14 e 15). A funcionária desse setor informou que os livros seriam disponibilizados não apenas para alunos, mas para todos, mediante inscrição. A lateral da biblioteca se abriria para um espaço de convivência, com móveis compactos e robustos, os "puffs", onde alunos aproveitariam para aguardar o início das aulas, nos intervalos, e encontrar os colegas (Figura 16). Deste espaço, abre-se uma porta, dando para o auditório, que acumularia várias funções: palestras, aulas inaugurais dos cursos, apresentações de peças de teatro, entre outras (Figura 17). Destaque-se a sinalização interna do edifício, concebida de forma muito clara e eficiente. Ainda, buscando proporcionar a seus alunos mais espaço de convivência, o antigo estacionamento foi desativado e decorado com mesas, cadeiras, guarda-sóis e, segundo relato de professores, algumas aulas também seriam dadas neste local (Figura 18).

Em relação às demais estruturas materiais e físicas, a Respondente 30, professora, ao citar a proposta de determinada atividade na segunda etapa do PI [Projeto Integrador], informou que envolveria a criação de logotipos. Segundo ela, "Essa aula eu boto prancheta, eles começam a criar. Eu vou trabalhar com massa de modelar. Eles vão modelar mesmo a tipografia e o símbolo" (Figura 19). De modo similar, a Respondente 29, outra professora, também comentou a utilização de suportes e materiais diferenciados para desenvolvimento de trabalhos: "A gente tem 
disponibilidade de mesas de desenho, lápis de cor. Eles não precisam trazer, porque já tem aqui, faz parte do curso deles". Estas declarações parecem indicar que em escolas da rede Senac haveria salas que possibilitariam a inclusão de suportes adequados, como pranchetas, para desenvolvimento de atividade com abordagens mais manuais, mais empíricas, isto é, especialmente relacionadas ao universo das artes plásticas.

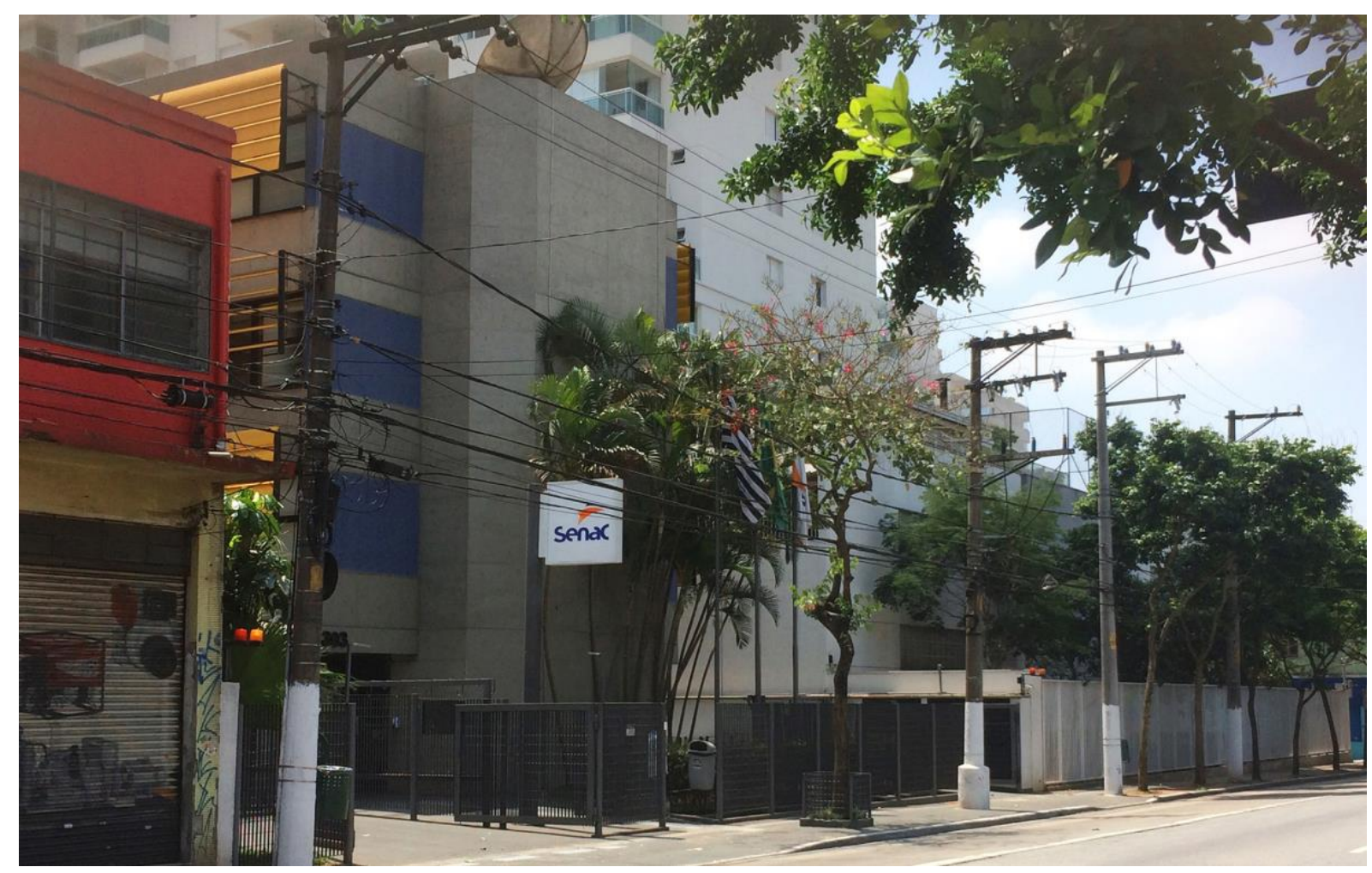

Figura 13:

fachada Senac Largo Treze

A Respondente 38, ex-aluna, relatando as estruturas materiais e físicas da unidade escolar de seu curso técnico (não correspondendo a unidade anteriormente mencionada), além dos laboratórios de informática, mencionou, também, a biblioteca. De acordo com ela, "A gente saía da aula, ia p'ra biblioteca, ainda tinha computador p'ra mexer, livros p'ra gente consultar, professores sempre a disposição. A infraestrutura do Senac é nota 10". Sua fala sugere que a biblioteca seria um espaço frequentado na escola, ao menos por parte de seus alunos, para desenvolvimento de pesquisas (por meio de seus livros e de seus computadores) e demais atividades pedagógicas. 


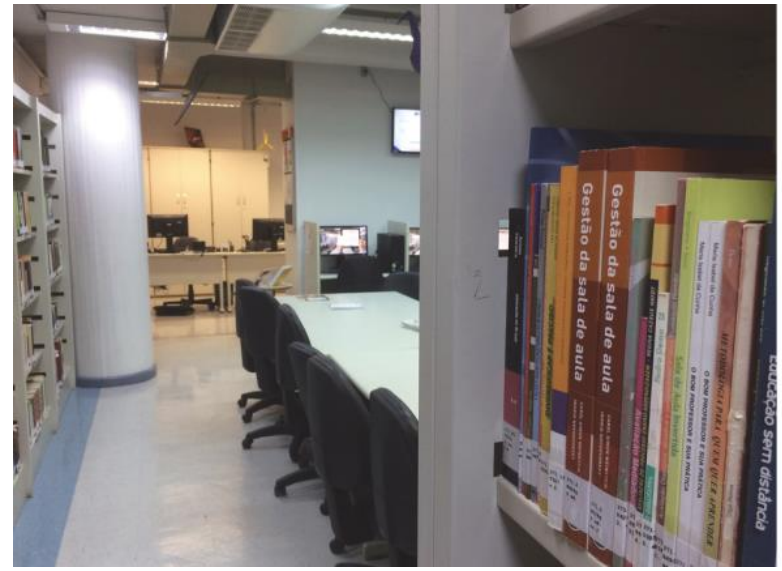

Figura 14:

biblioteca

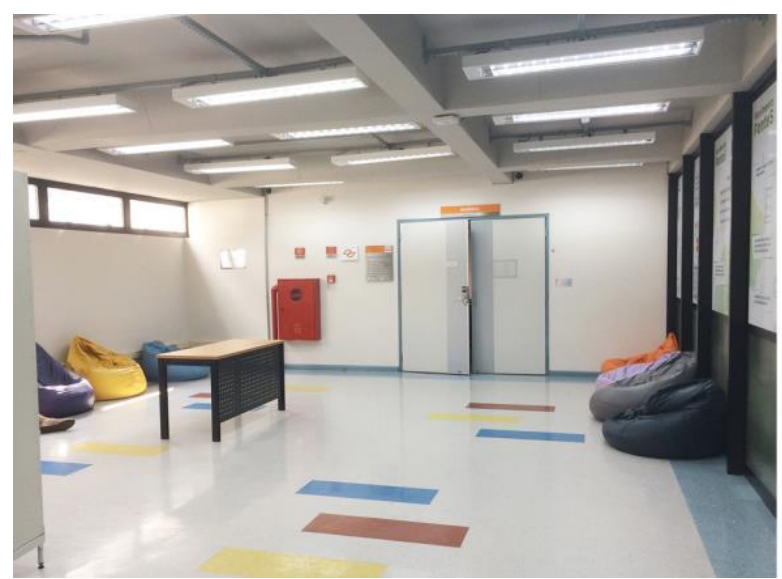

Figura 16:

área de convivência interna

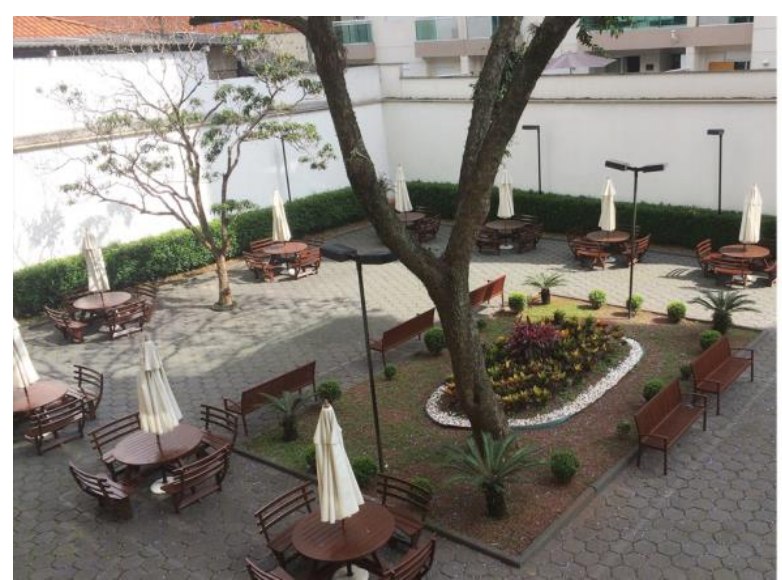

Figura 18:

área de convivência externa

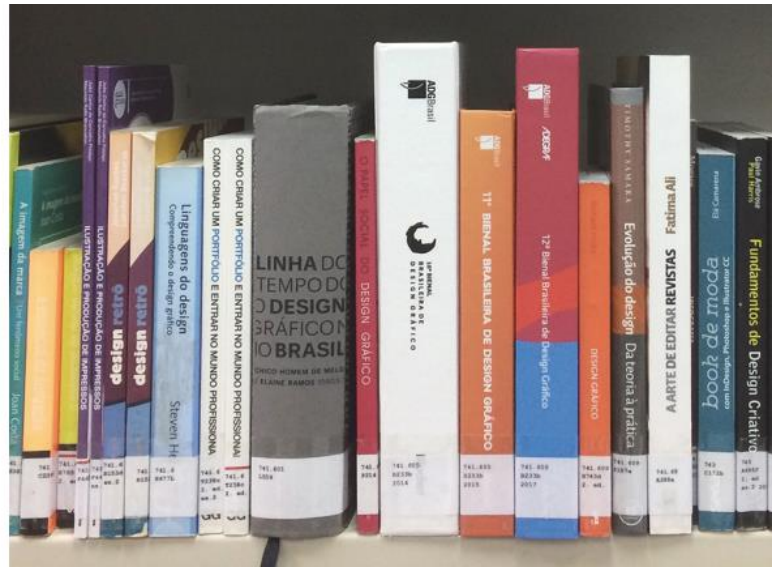

Figura 15:

livros de design e de áreas afins

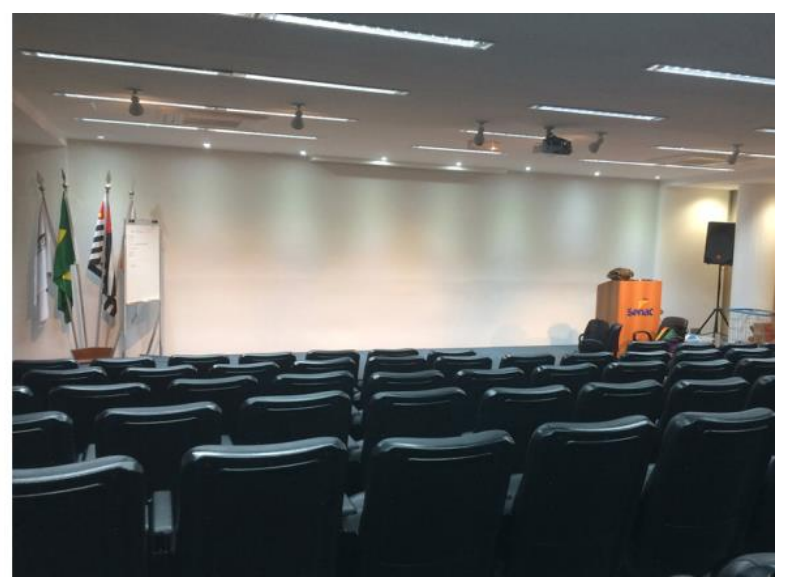

Figura 17:

anfiteatro

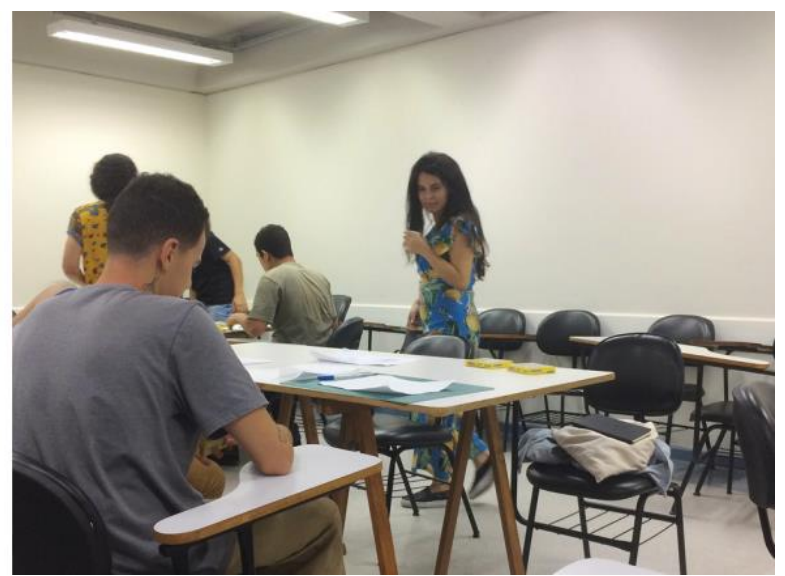

Figura 19:

sala de aula adaptada com pranchetas 
De maneira semelhante, a Respondente 37, outra ex-aluna já citada, destacou como relevante, na estrutura física da unidade escolar da rede Senac que frequentou em seu curso técnico, o espaço da biblioteca. Segundo ela, "A infraestrutura do meu técnico era maravilhosa! Acho que a gente nem aproveitou tudo o que poderia. [...] A biblioteca, eu usei bastante. Tinha um bom espaço p'ra convivência, era muito gostoso. Eu passava o dia inteiro lá". Este trecho de seu depoimento sugere, assim como no caso da Respondente 38, sua satisfação com a estrutura física geral e com o ambiente escolar de seu curso técnico, a ponto de lá permanecer o dia todo.

Os dados comentados acima sugerem que, potencialmente, as escolas da rede Senac, ao exporem os alunos a ambientes e materiais menos convencionais, com abordagens também alternativas, estariam estimulando habilidades sensoriais, motoras, cognitivas e sociais. Pelo fato de espaços destinados à convivência como pátios e lanchonetes, além de um local para desenvolvimento de pesquisas e outras atividades pedagógicas, como as bibliotecas - haverem sido mencionados por alunas egressas de cursos técnicos de comunicação visual, pressupõe-se que o Curso incentivaria a socialização e prática investigativa, contribuindo, em certa medida, para formações mais especialmente completas.

\subsection{2}

\section{Laboratório de informática, equipamentos e aplicativos gráficos disponíveis}

\subsubsection{1}

\section{Perspectivas de respondentes associados a escolas da rede Etec-SP}

Quanto às estruturas materiais e físicas, o Respondente 2, professor, informou que a escola possuiria laboratórios equipados com 10 a 12 computadores Macintosh com os aplicativos Photoshop, Illustrator e InDesign (Figura 20) e laboratórios de PC com Photoshop, Illustrator, Pagemaker e CorelDraw (Figura 21). O mesmo Respondente 2 declarou que o curso iniciaria, normalmente, com 40 alunos, divididos em duas turmas. Segundo ele: "A aula dividida é uma metodologia do Centro Paula Souza para que o aluno consiga ter mais propriedade nos equipamentos ou nas orientações" e, desse modo, com 20 alunos no laboratório, ficariam dois alunos 
por computador no $1^{\circ}$ módulo , o que com a natural evasão, nos $2^{\circ}$ e $3^{\circ}$ módulos, resultaria em quase um computador por aluno, dando-se prioridade ao aluno que estivesse com o projeto em andamento, como forma de incentivo à produção. Seu relato pressupõe que a quantidade de computadores em relação a alunos não seria a ideal e que uma situação não favorável, como a evasão escolar, melhoraria as condições gerais de aprendizado.

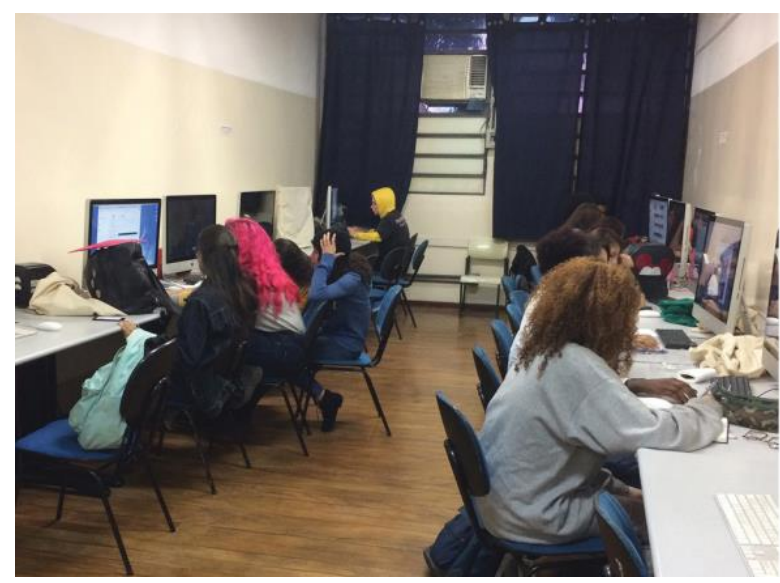

Figura 20:

laboratório de "Macs"

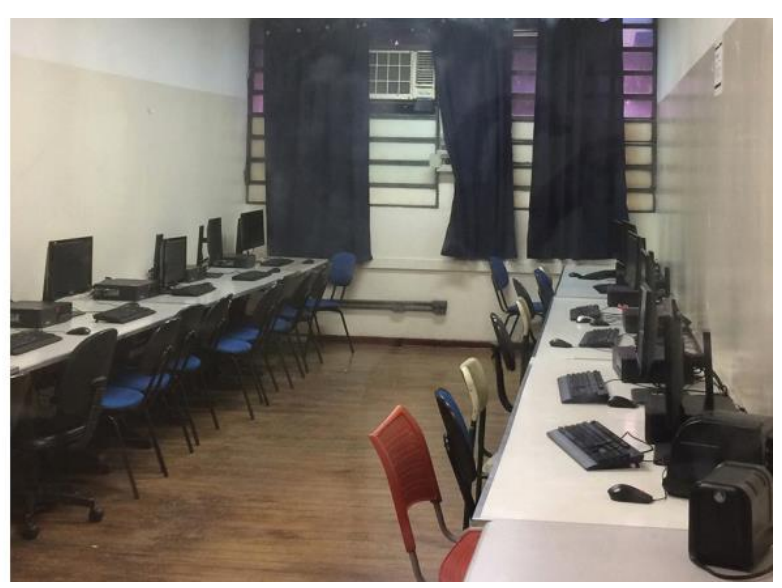

Figura 21:

laboratório de "PCs"

Para a Respondente 25, ex-aluna do curso não vinculado ao ensino médio, o dito "modular", os computadores seriam apropriados: "Na Etec, o laboratório de computador era muito bom porque eles usavam Macs". Esta passagem sugere satisfação no uso dos computadores Macintosh, uma vez que seriam os mais indicados para desenvolvimento de projetos gráficos. Complementarmente, o Respondente 26, outro ex-aluno do "modular", informou a percebida adequação dos laboratórios. Para ele, "Era uma sala bem dimensionada, um pouco escura, então, a gente conseguia acompanhar o professor no slide enquanto mexia no computador nosso. Então, era bastante confortável”. Este segmento parece indicar que os laboratórios de Macs seriam apropriados para o desenvolvimento das atividades. Em relação ao seu uso, declarou que haveria algumas restrições: "Tinha uma sala que era só p'ra 'CV', que era a de Macs e só podia usar com o professor. Tinham alguns que davam problemas. Eventualmente, a gente tinha que dividir. [...] Com o tempo, eu acabei levando meu notebook e sempre usando ele". Sua fala denota que a quantidade de computadores Macintosh nem sempre seria suficiente para uso individualizado e, ainda, que nem todos estariam permanentemente 
em condições de utilização, sendo esta a razão pela qual esse respondente decidira portar o próprio computador na escola.

Quanto à introdução dos computadores no curso técnico de comunicação visual, o Respondente 2, professor citado, informou que teriam chegado à escola no início dos anos 1990 e provocado certo descontentamento em alguns professores: "[...] gradativamente, nós fomos visualizando que não tinha volta, a área de comunicação visual estava intrinsicamente ligada ao computador, já naquela época". Uma possível razão para explicar tal resistência à introdução dos computadores na instituição seria a ausência de afinidade de alguns professores com o universo digital. Informou que, concomitantemente, iniciou-se o ensino de aplicativos, como o Pagemaker e o CorelDraw: "[...] p'ra separar qual era a plataforma que melhor o software trabalharia com ilustração e qual ele trabalharia mais com paginação, considerando que ele tinha que editar, trabalhar com imagem e texto, então, eram os clássicos" e que, um pouco mais tarde, o Photoshop teria sido adotado.

De maneira convergente ao relato da Respondente 25, a Respondente 23, outra ex-aluna do "modular", recordando sua experiência preliminar com os computadores Macintosh, mencionou ter se surpreendido. Segundo ela, "Eu lembro muito dos Macs, porque a tela deles era bem grandona. A primeira vez que a gente vê um Mac: nossa, meu Deus, que lindeza! [...] A gente tinha que dividir, às vezes dava sorte de não precisar, dependia um pouco do dia”. Já a Respondente 24, também ex-aluna, quanto ao uso dos computadores, informou que seriam destinados somente aos alunos de comunicação visual: "Tinham 20 Macs e os alunos dividiam de dois em dois. Era muito bom. Só o curso técnico de comunicação visual usava o laboratório de Mac". Estes depoimentos parecem indicar que, dependendo da unidade escolar da rede Etec, haveria maior ou menor índice de compartilhamento de computadores Macintosh. Sugerem, ainda, que em módulos iniciais, quando o número de alunos normalmente seria superior ao de módulos mais avançados, haveria maior incidência de coparticipação de computadores.

O Respondente 4, outro professor, quanto aos computadores disponíveis na época em que ingressara no Curso, declarou considerá-los inadequados. Para ele, 'Quando eu entrei aqui, na primeira década de 2000, tinham uns '386' muito velhos. 
Eram quatro, cinco computadores p'ra 15 alunos. Então, a gente improvisava. Fazia o que dava. Hoje não, tem Mac!". Entretanto, de acordo com o mesmo Respondente 4, além de os computadores estarem atualizados, para adquirir conhecimento em aplicativos de design tridimensional seria fundamental ter um computador por aluno: "[...] não adianta dividir porque, se você cai com alguém que já conhece, você não vai aprender, o cara vai fazer o trabalho. Você se safa da disciplina, mas não aprende". Tal depoimento corrobora o do Respondente 9, aluno do "modular" diurno, ao se referir à quantidade de computadores. Segundo ele, "Faltou ter Macs suficientes p'ra fazer o manual de identidade visual". Sua fala sugere que, possivelmente, haveria certo comprometimento no desenvolvimento da atividade proposta pela falta de equipamentos.

Por sua vez, a Respondente 28, uma ex-aluna do Etim, comentando a respeito dos laboratórios de computador, também informou ser limitado seu uso.

De acordo com ela, "[...] o laboratório de Macs era trancado. Eram uns 20 Macs. Tinha filme plástico no teclado e no mouse. Era só o pessoal de 'CV' que usava. A turma ia dividida. Era uma vez por semana e a gente só foi mexer no $3^{\circ}$ ano. Nos dois primeiros, foi só PC". Similarmente, a Respondente 27, outra ex-aluna do Etim, também declarou exclusividade de um grupo particular de alunos no uso de determinado laboratório de informática. Segundo ela, "A gente tinha um laboratório específico, com uns 20 Macs, aqueles grandões. [...] A gente só teve acesso aos Macs no $3^{\circ}$ ano p'ra fazer o TCC. Eram 40 alunos. [...] Tinha um Mac p'ra cada aluno, porque a turma era dividida e ia metade por vez". Observe-se que o laboratório de computadores Macintosh permaneceria fechado, com proteção nas peças mais manuseadas, sendo sua utilização restrita a alunos do curso de comunicação visual e, apenas, aos do último período letivo. Isto sugere atenção em manter equipamentos, presumidamente caros, sob cuidados. Revela, ainda, entendimento da importância em disponibilizar, ao menos aos estudantes mais avançados, acesso a computadores considerados mais adequados para atividades relacionadas ao design.

De maneira complementar, o Respondente 6, outro professor, mencionou que os equipamentos seriam bons, contudo, um maior número e sua diversidade seria ainda melhor: "[...] por exemplo: mais scanners na sala de aplicativos, talvez, uma 'Cintiq'. É uma mesa digitalizadora que você já desenha direto na tela, ou ipad mesmo, 
já ajudaria". Isto sugere compreensão do docente de que equipamentos mais novos e modernos possibilitariam um aprendizado mais amplo e eficiente. Apesar de não utilizar computador em suas aulas, a Respondente 3, igualmente professora, declarou que, de modo geral, faltaria investimento no curso: "[...] começando pelos computadores, começando pelas capas de computador. Não tem infraestrutura. O que falta é investimento e ser mais valorizado". Uma possível explicação para esta afirmação seria a percebida falta de aplicação de recursos em cursos técnicos na infraestrutura em geral, incluindo a remuneração de seus professores.

Os dados sistematizados nesta seção sugerem que, desde a implantação dos computadores nas unidades escolares da rede Etec, haveria progresso em termos de qualidade dos equipamentos, parecendo, no entanto, conveniente sua atualização. Também revelam que a quantidade de máquinas em relação ao número de alunos não seria a ideal, devido à restrição no uso dos laboratórios de computadores Macintosh a alunos de cursos de comunicação visual e seu eventual compartilhamento em função da modalidade e estágio do curso. Ainda, pressupõem que os aplicativos disponibilizados parecem adequados às propostas, contudo atualizações periódicas seriam bem-vindas.

\subsubsection{2}

\section{Perspectivas de respondentes associadas a escolas da rede Senac-SP}

A Respondente 29, professora já citada, ao mencionar a dinâmica de aula, informou a ênfase dada à prática em computador (Figura 22). Segundo ela, "Eles [alunos] preparam bastante seminário. Tem a básica, a apresentação, mas também tem exposição de vídeo, faz trabalho em grupo e apresenta o trabalho. [...] Mais da metade das aulas eles trabalham no computador". Note-se o elevado número de atividades pedagógicas que seriam desenvolvidas em computador, sugerindo presença de laboratórios de informática adequados em escolas da rede Senac.

Relembrando as estruturas materiais e físicas da escola em que cursara o ensino técnico, a Respondente 36, uma ex-aluna, destacou o laboratório de computadores Macintosh. De acordo com ela, "No [curso] técnico tinha um computador p'ra 
cada aluno. Tinham aproximadamente 20 a 30 pessoas. A gente mexia no 'Mac'. A estrutura lá é muito boa". Tal trecho de seu depoimento revela que, na unidade da rede Senac em que teria cursado o ensino técnico de comunicação visual, não haveria compartilhamento de máquinas nas aulas em laboratório de computadores Macintosh, o que favoreceria o aprendizado.

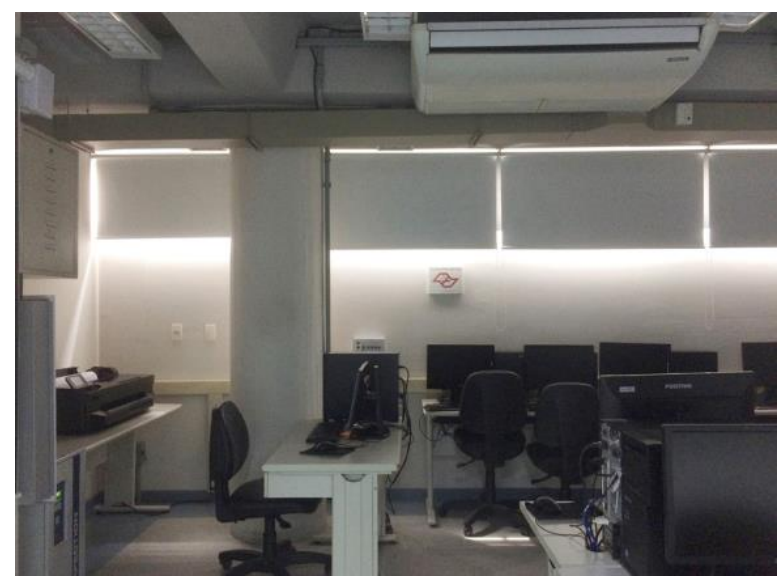

Figura 22:

laboratório de informática com computadores "PC"

De maneira similar, a Respondente 38, também ex-aluna, relatando a estrutura material e física da escola que frequentou no curso técnico, mencionou, como relevante, os computadores destinados aos alunos do curso técnico de comunicação visual. De acordo com ela, "[a estrutura] era ótima. Os 'Macs'. Eu nem sabia o que era 'Mac' antes de entrar". De maneira muito similar, a Respondente 37, outra ex-aluna, demonstrou grande entusiasmo em relação à qualidade dos computadores. "Achei bom os 'Macs'”. Estas declarações parecem indicar contentamento da totalidade de tais alunas egressas de cursos técnicos de comunicação visual com os computadores disponibilizados para uso discente.

Os dados apurados acima sugerem atenção das escolas da rede Senac em disponibilizar a seus alunos, pelo menos aos de cursos técnicos de comunicação visual, laboratórios de informática equipados com computadores Macintosh, percebidos como sendo os mais adequados para a execução de projetos gráficos, o que parece estar de acordo com o caráter mais prático do ensino técnico - que, em princípio, seria caracterizado por ser mais voltado à formação para o mercado de trabalho. 


\section{4 \\ Resultados concernentes ao subproblema 4 (abordagens pedagógicas)}

\subsection{1}

\section{Estrutura curricular geral dos programas de escolas técnicas selecionadas}

Os dados analisados na categoria temática apresentada nesta seção foram agregados, inicialmente, em função da natureza da estrutura curricular geral do programa: ser ou não integrado ao ensino médio (Etim). Por sua vez, no interior de cada uma destas duas subseções produzidas, separaram-se os dados analisados em subseções correspondentes às duas principais redes de escolas técnicas cobertas pela pesquisa: a Etec-SP e o Senac-SP. Observe-se, entretanto, que na rede Senac-SP não há ensino técnico de comunicação visual integrado ao médio.

\subsubsection{1}

\section{Estrutura curricular geral dos programas de escolas técnicas selecionadas não vinculadas ao ensino médio}

\subsubsection{1}

\section{Perspectivas de respondentes associados a escolas da rede Etec-SP}

Quanto à estrutura curricular geral dos programas de escolas técnicas selecionadas, a Respondente 1, professora, informou que o curso técnico não vinculado ao ensino médio, o dito "modular", seria composto por três módulos, correspondendo a um semestre cada, com duração de um ano e meio. De acordo com ela, o módulo 1 seria formado por disciplinas destinadas a fornecer ferramentas básicas e, também, a propiciar execução de algumas atividades, excluindo-se propostas que impliquem projetos completos. A mesma Respondente 1 relatou que o módulo 2 seria destinado à aplicação de conceitos adquiridos no semestre anterior para desenvolvimento de projetos, em certos casos, por meio de atividades interdisciplinares, citando, como exemplo, o projeto gráfico de uma revista que envolveria quatro disciplinas. 
Já o módulo 3 seria reservado ao Trabalho de Conclusão de Curso (TCC), previsto para ser executado de duas maneiras: a primeira seria identificar um cliente real no mercado e desenvolver toda sua identidade visual, sendo aplicada ou não pelo cliente após seu término. A segunda opção seria desenvolver um projeto, em grupo ou individualmente, a partir de uma proposta da escola ou do professor responsável que apresentaria um tema/cliente com possibilidade de execução de diversas peças. O Respondente 2, outro professor, em complemento, destacou a necessidade de se pensar em produtos que atendam ao setor "educativo"9 de instituições culturais. Ainda quanto à grade curricular, a Respondente 7 , também professora, apesar da presença de disciplina de história da arte nos três módulos, consideraria o enfoque muito acadêmico e sentiria falta de história do design em cursos de design gráfico.

De modo similar, a Respondente 24, ex-aluna, explicando a estrutura curricular de sua escola, informou ser dividido em três semestres, havendo diferença de abordagem entre as disciplinas. Segundo ela, "Tinham matérias que tinham exercícios diferentes toda a aula. Não era um longo projeto. [...] Duas matérias tinham projetos maiores, de branding, identidade visual e TCC [...]. Mas era muito mais pontual. Era uma evolução na teoria". Observe-se que haveria disciplinas com propostas mais breves e outras mais elaboradas, que demandariam mais tempo para sua execução. Isto sugere atenção em promover o desenvolvimento de habilidades e competências a partir de atividades mais curtas para sustentar a realização de projetos mais complexos. Pressupõe, também, existência de progresso nos fundamentos ministrados, embasando as atividades práticas.

Complementarmente, o Respondente 26, outro ex-aluno, referindo-se à grade curricular, informou considerá-la apropriada. De acordo com ele, "A grade, eu achava boa. A sequência de disciplinas, eu acho que era bem razoável". Sua fala sugere percepção de coerência de conteúdos com os objetivos propostos, porém o mesmo Respondente 26 apontou a falta de integração entre as matérias. Para ele, "[...] tinham muitas disciplinas que não estavam articuladas entre si. [...] A gente perdia nesse sentido, perdia tempo, porque tinha que fazer duas coisas diferentes com o mesmo objetivo que era, por exemplo, aprender o software

\footnotetext{
${ }^{9}$ Setor educativo: setor específico criado para atender o público escolar sobremaneira.
} 
no computador". Tal passagem pressupõe que a ausência de relação entre saberes das diferentes matérias estaria, algumas vezes, gerando retrabalho, comprometendo, em certa medida, o aprendizado.

Quanto à possível necessidade de adequação de conteúdos, o Respondente 4, igualmente professor, informou a existência, no Centro Paula Souza, do chamado “Laboratório de Currículo", em que, a partir de levantamento realizado com profissionais do mercado, coordenadores dos cursos debateriam a introdução, permanência e exclusão de determinados conteúdos e disciplinas. O mesmo Respondente 4 assinalou que o instrumento de trabalho que referencia conteúdos, metodologias, procedimentos e técnicas a serem utilizados no processo de ensino-aprendizagem estaria bem estruturado. Para ele, 'Esse 'Plano de Curso' de comunicação visual 'tá bem sólido, a gente chegou num ponto de saturação dele, ele tem uma base boa e essa base não tem muito o que mexer". Relatou, ainda, que o Plano de Curso seria o mesmo para cada unidade, contudo cada professor precisaria adequá-lo à realidade de sua região, como exemplificado: "Na disciplina que eu leciono, 'Aplicativos Informatizados em Design Gráfico', o software é o mesmo, o procedimento que você tem que ensinar é o mesmo, mas, dependendo da região, o professor vai adaptar p'ra realidade dele". Seu relato sugere intenção do Centro Paula Souza em manter os currículos dos cursos atualizados, assim como crença, por parte do Respondente 4, de que as disciplinas presentes na grade curricular de comunicação visual estariam contribuindo de forma adequada para a formação do futuro profissional da área.

Os dados sistematizados sugerem atenção em expor os alunos a conteúdos e atividades mais gerais no primeiro módulo antes de solicitar um projeto, estratégia que também foi utilizada na Bauhaus e posteriormente na Sequência de Comunicação Visual, nos primórdios da FAU da USP (DIAS, 2015). Pressupõem, ainda, preocupação do Centro Paula Souza em manter os currículos de seus cursos técnicos atualizados. Contudo, a menção à falta de articulação entre as disciplinas indicaria, talvez, conveniência de revisão no planejamento. 


\subsubsection{2}

\section{Perspectivas de respondentes associados a escolas da rede Senac-SP}

A Respondente 29, professora, informou que, de acordo com o Plano de Curso do Senac-SP, o programa seria organizado em quatro "Qualificações Profissionais Técnicas" (QPT): "P'ra cada QPT, o aluno recebe um certificado. 'Tá ramificado para quem quer se especializar só em uma coisa". De modo complementar, a Respondente 32, outra professora, acrescentou que o curso teria se desmembrado: "[...] o curso foi segmentado por falta de tempo das pessoas. Para as pessoas tentarem conseguir um emprego com um curso de qualificação". A mesma Respondente 29 explicou, ainda, que o curso iniciaria pela QPT "Assistente de Arte" [240 horas]: "[...] começa com Photoshop, Illustrator, conceitos, história da arte" e a ordem das demais QPTs poderia ser alterada, dependendo da turma.

Segundo ela, “[...] a QPT 'Programação Visual de Design Editorial' mexe com InDesign, fazer livro, revista. 'Programação Visual de Design Institucional' é logotipo, manual de identidade visual e 'Programação Visual de Design Promocional' é embalagem, ponto de venda". ${ }^{10}$ Observe-se que haveria certa flexibilização na ordem das QPT, sugerindo atenção ao perfil discente, que variaria de turma para turma, o que contribuiria para um aprendizado mais uniforme.

Ainda, segundo a mesma Respondente 29, haveria certa resistência no Senac-SP quanto a pensar o ensino como conteudista. Para ela, "Aqui, no Senac, se trabalha com 'Unidade Curricular' (UC), não por matéria. Como aqui tem um conceito construtivista, o ensino não é: matéria, nota, acabou. É bem mais complexo. Se trabalha com indicadores, não com conteúdo". Assim, exemplificou que a primeira QPT (Assistente de Arte) seria composta por quatro UCs, cada qual com três a quatro indicadores, mais a UC 5, que seria o "Projeto Integrador" (PI). Segundo ela, "A gente foca nesse Projeto Integrador unindo todas as UCs. Seria um TCC, digamos assim. [...] É tudo concomitante. A gente começa a qualificação técnica já avisando do Projeto Integrador". Sua fala parece indicar que o Projeto Integrador seria uma espécie de coluna vertebral, estruturando todo o curso, desempenhando papel relevante no desenvolvimento dos alunos. Declarou, ainda, que apesar de sugerirem Institucional" [160 horas] e "Programação Visual de Design Promocional" [160 horas]. 
o tema, os alunos teriam total liberdade de escolha: "[...] eles têm que se identificar com ele. A proposta é que os alunos tenham autonomia. Autonomia em todos os sentidos: tanto de saber o tema que quer, quanto de ter uma pró-atividade na pesquisa". Esta passagem sugere que o curso visaria a preparar o indivíduo a ter iniciativa, tomar decisões, característica essencial em ambiente de trabalho.

Ainda, sobre a distinção entre o ensino, a Respondente 30, professora já citada, informou que, anteriormente, quando a grade curricular era formada por módulos, existiriam elementos da competência, que corresponderiam ao conteúdo. Para ela, "Atualmente, tem que entender que [entre os] elementos do conhecimento, você tem o próprio conhecimento, habilidades, atitudes, valores, princípios, envolve tudo isso. Conhecimento é só o técnico, as leis, as teorias". Entretanto, sugeriu ela, isso não seria suficiente: "[...] o cara, p'ra poder executar, ele vai trabalhar em equipe. Então, ele tem que ter atitudes e valores perante o social, por exemplo: vamos criar um material gráfico que não impacte tanto". Sua fala pressupõe que conhecimentos técnicos seriam importantes, mas, para uma formação integral, seria oportuno incluir a dimensão do social tanto no âmbito da convivência quanto nos projetos propriamente ditos.

De modo complementar, a Respondente 36, ex-aluna, comentou que, na época em que cursara o Técnico em Programação Visual (2016-2017), o programa seria estruturado em módulos. Em relação ao primeiro, considerou haver sido bastante experimental, pois, segundo ela: "[...] sinceramente eu fiquei bem perdida por não saber nada da área. [...] P'ra você conhecer as ferramentas, você não tinha muito que seguir uma ideia ou um conceito, não tinha que [se] aprofundar muito no estudo". Seu relato sugere que o foco do primeiro módulo seria o de apresentar as ferramentas, não sendo propostas pesquisas. Quanto ao módulo seguinte, a pesquisa seria incentivada, havendo mais orientação dos docentes para o desenvolvimento de um determinado projeto: "[...] no segundo foi identidade visual, a gente já teve que fazer um estudo maior de pesquisa p'ra fazer uma marca. Quando chegou na identidade visual, a professora explicou que não podia sair do nada a marca e que tinha que fugir do óbvio". Este trecho do seu depoimento parece indicar que, a partir do segundo módulo, haveria preocupação em alinhar os conteúdos e abordagens do estudo com demandas de trabalho profissional. 
Quanto à própria percepção em relação à estrutura curricular, a Respondente 38, também ex-aluna, relatou: "O que ficou na minha cabeça foram os projetos. [...] Acho que a sequência 'tá correta, porque a embalagem é mais complexa. Porém, a revista deu mais trabalho, era uma quantidade maior de material p'ra você cuidar, só que era feita em grupo". Tal fragmento sugere, primeiramente, noção de que um módulo corresponderia a um projeto. Pressupõe, ainda, a ideia de que, a cada módulo, haveria um incremento na complexidade dos trabalhos. A mesma Respondente 38 mencionou considerar adequado o encadeamento dos projetos: "Quando eu fui fazer a embalagem, eu tinha noção do tempo que eu tinha e quanto tempo eu tinha que gastar p'ra fazer. [...] Mas eu tinha aprendido com os outros projetos, principalmente com a revista, que a gente entregou bem apertado". O relato sugere que, para essa respondente, a sequência dos módulos seria adequada, pois promoveria aprendizado a partir de experiências anteriores de projeto.

Os dados apontam para uma restruturação no Curso Técnico em Comunicação Visual do Senac-SP, que passou a ser organizado em "Qualificações Profissionais Técnicas" (QPT), equivalendo, em certa medida, aos antigos módulos. Cada QPT seria composta por determinado número de "UCs" (Unidades Curriculares), cada qual com quantidade variada de indicadores (e não conteúdos). Haveria, ainda, mais uma UC, correspondendo ao "Projeto Integrador" (PI), realizado simultaneamente às demais UCs. Chama a atenção a possibilidade de alterar a ordem das QTPs, bem como de serem cursadas independentemente das demais. Os dados também apontam para o incentivo ao protagonismo do aluno perante seus estudos, além de valorização de uma formação integral, com a inclusão da dimensão do social no âmbito da convivência e nos projetos em si. 


\subsubsection{2}

\section{Estrutura curricular de programas de escolas técnicas integradas ao ensino médio (Etim)}

\subsubsection{1}

\section{Perspectivas de respondentes associados a escolas da rede Etec-SP}

A Respondente 1, professora, comparando o ensino técnico não vinculado ao ensino médio com o Etim, considera-os bem diferentes. De acordo com ela, no Etim: "[...] o tempo é maior, em compensação, eles estão muito envolvidos com o ensino médio. Aos poucos, eles vão reconhecendo mais a área. Eu acho que é problema de grade curricular, porque eles têm poucas matérias do 'modular' no primeiro módulo". Este trecho do seu depoimento pressupõe que a baixa quantidade de disciplinas relacionadas à comunicação visual aliada a um número considerável de matérias do ensino médio estaria contribuindo para percebida diferenciação do real interesse e habilidade para a área da comunicação visual entre alunos cursando o Etim com os do "modular". No entanto, a mesma Respondente 1 citou que a disposição evoluiria: "Quando eles começam a entender a área, começam a se voltar mais. Aí, você vai percebendo quem vai se adaptando melhor, quem vai demonstrando mais habilidade p'ra área, quem se define. Porque, nem todo mundo que entra, vai seguir na área". Esta passagem parece indicar que o aumento quantitativo de disciplinas técnicas em módulos mais avançados facilitaria a compreensão a respeito da comunicação visual, gerando mais interesse e dedicação de seus alunos. Sugere, ainda, que a falta de conhecimento das atribuições da área ao ingressarem no curso, possivelmente pela pouca idade, favoreceria o não prosseguimento dos estudos neste campo por parcela de seus alunos.

A Respondente 27, uma ex-aluna do Etim, relatando a estrutura curricular geral dos programas, informou considerá-la pertinente. Para ela, "A grade curricular do curso é bem interessante. A maioria das matérias era importante e necessária. Elas eram coesas com o curso e com o que você deveria aprender, porém, poderiam ter sido mais bem dadas e ter uma estrutura melhor p'ra dar". Sua declaração pressupõe que os componentes curriculares do ensino técnico em comunicação 
visual integrado ao médio seriam percebidos como adequados, porém a estrutura disponível e, talvez, o modo como algumas disciplinas seriam ministradas, nem tanto.

Ainda, quanto à estrutura curricular do Etim, a mesma Respondente 27 informou considerá-la, em certa medida, desorganizada. Segundo ela, "Como o meu era Etim, era meio bagunçada a grade. Isso acaba dificultando um pouco o aprendizado e eu acho que tira a qualidade dos dois ensinos". Sua declaração parece indicar que a grade curricular do Etim não seria estruturada adequadamente, prejudicando o aproveitamento em disciplinas tanto do curso técnico quanto do ensino médio. Entretanto, ao compará-la com a grade curricular do curso técnico não integrado ao ensino médio, a mesma Respondente 27, acreditaria ser semelhante, pois, para ela, 'Vendo os trabalhos das pessoas do 'modular', eu percebo que a minha sala, que fazia 'integrado', tinha um nível mais baixo. [...] Em relação ao 'modular', a grade era bem parecida ou a diferença era bem pouca". Observe-se que, apesar de os conteúdos das duas modalidades de ensino serem equivalentes, os resultados de trabalhos dos alunos do curso dito "modular" seriam percebidos como de melhor qualidade. Isto parece indicar que a diversidade e a quantidade de disciplinas do Etim (compreendendo três anos letivos) dificultariam o planejamento da grade curricular, pressupondo maior atenção em seu planejamento.

Complementarmente, o Respondente 26, ex-aluno citado do curso não integrado ao ensino médio, comparando as duas modalidades de cursos, informou considerar o ensino do Etim defasado em relação ao dito "modular". Segundo ele: "Quando era o modular, tinha uma predefinição de quais professores dariam aula em cada semestre. Quando entrou o Integrado, os horários eram manhã e tarde misturados com o médio. Alguns não conseguiam dar aulas, iam professores de outras áreas p'ra cobrir". Note-se que, na época em que seriam ofertados apenas cursos técnicos de comunicação visual independentes do ensino médio, haveria certa gerência das disciplinas (e de seus docentes) com horários de aulas. Ao oferecerem cursos técnicos desta área integrados ao ensino médio (compreendendo períodos da manhã e tarde), parte dos professores da modalidade técnica não teria disponibilidade de horários, sendo substituídos por docentes de outras áreas. Isto pressupõe que a qualidade do ensino teria sido prejudicada, uma vez que certas aulas seriam ministradas por professores não especialistas no assunto. 
Os dados apurados acima parecem indicar que, apesar de haver certa similaridade entre os conteúdos técnicos das duas modalidades de curso, o ensino técnico não vinculado ao ensino médio, o dito "modular", seria percebido como de melhor qualidade em relação ao ensino técnico vinculado ao ensino médio, em razão de uma série de características do Etim, entre as quais: carga horária robusta; grade curricular mal estruturada; falta de correspondência entre formação e disciplina ministrada por parte de professores especialistas, entre outras. Isto pressupõe que, revendo-se tais pontos, o ensino, potencialmente, poderia ser melhorado.

\subsection{2}

\section{Aspectos didático-metodológicos}

Os dados analisados na categoria temática apresentada nesta seção foram separados em subseções correspondentes às duas principais redes de escolas técnicas cobertas pela pesquisa: a Etec-SP e o Senac-SP.

\subsubsection{1}

\section{Perspectivas de respondentes associados a escolas da rede Etec-SP}

Em relação a aspectos didático-metodológicos, segundo a Respondente 1, professora, a maioria dos docentes chegaria com uma parte teórica, exposta por meio de uma apresentação no datashow, ou pontuaria, na lousa, a atribuição, a proposta, os aspectos importantes da disciplina e do projeto a ser pedido: "O professor monta na lousa o projeto e suas etapas, do briefing às peças que serão criadas. Mas boa parte traz uma apresentação, no PowerPoint ou PDF e, no caso da comunicação visual, inclui mostrar uns cases, uns exemplos". Isto parece indicar atenção dos docentes no sentido de apresentar referências visuais que auxiliem no processo criativo, bem como no de deixar claro ao aluno o que se espera dele. A mesma Respondente 1, ainda, citou a obrigatoriedade da aula inaugural nas Etecs: "[...] torna-se público para o aluno as bases tecnológicas que ele vai aprender, os instrumentos e critérios de avaliação. [...] Isso vira uma evidência, a gente pede p'ra ele assinar". 
De modo similar, a Respondente 3, outra professora, responsável pela disciplina "Formas Expressivas Bidimensionais" (FEB), informou que colocaria a proposta na lousa; além disso, levaria exemplos e abordaria, um pouco, a vida e obra de artistas (a partir do que aprenderam em história da arte): "Você vai trazendo alguma coisa, um conteúdo que cative, que desperte o interesse do aluno por aquela atividade. Você não pode chegar, simplesmente e começar a pintar". Sua afirmação sugere que os alunos precisariam se identificar, de alguma maneira, com a proposta da disciplina para se desenvolver plenamente. A mesma Respondente 3 relatou que incentivaria, também, os alunos a pesquisar e, a partir de exemplos de ex-alunos bem-sucedidos, falaria a respeito da necessidade de aprender e conhecer um pouco de tudo: "[...] eu sempre falo alguma coisa que vai cativar o aluno. É assim que eu chego até eles. Eu mostro referências, os artistas e sempre demonstro a técnica". Seu relato sugere intenção de, mais do que ensinar técnicas, promover a sensibilização dos alunos.

Para o Respondente 5, também professor, o começo seria o momento chave, uma vez que as primeiras ideias tenderiam a não se concretizarem: "Se você não intervém muito rápido, muito forte, com muita personalidade nessa fase, o TCC se perde, eles vão continuar 'pesquisando'". Para minimizar tal situação, o mesmo Respondente 5, acharia oportuno, didaticamente, ter propostas muito claras, prazos muito curtos, com alguma atividade a ser entregue no próprio dia: "Se você não dá tempo, não dá prazo, não dá nota intermediária, não cobra, é uma eterna pesquisa volátil, nas nuvens, zapiando, algumas coisas, alguns rabiscos perdidos". Uma possível razão seria o fato de que alunos, quando não cobrados, apresentariam tendência a se dispersarem facilmente e a perderem o foco da atividade.

Ainda segundo a Respondente 1, a partir da proposta e/ou tema, a aula seria montada, contemplando conceitos, exemplos, além de filmes e séries:

"Acho que seria o nosso painel visual porque essa referência visual já dá uma incendiada na mente dos alunos e, então, a gente passa para um painel semântico'1". Esta abordagem parece indicar entendimento de que alunos

\footnotetext{
${ }^{11}$ Painel semântico é uma ferramenta de desenvolvimento de projetos de design em que se buscam estabelecer associações de grande número de significantes associados a algum dado significado de caráter mais abstrato.
} 
de comunicação visual necessitariam de certa diversidade e riqueza de referências visuais para formação de repertório que facilitariam seu processo criativo. Assim, também, procurariam identificar tendências do momento: "Você vai trabalhando com o conceito, porque, mesmo a imagem, tem que dizer alguma coisa conceitual do seu produto, daquilo que você 'tá representando. A mesma coisa um logo, de alguma maneira, tem que representar, é a essência de tudo". Nos casos em que o aluno apresentasse dificuldade em criar, seria orientado a fazer a primeira ideia que viesse à mente, para, na sequência, ir evoluindo: "[...] é uma maneira de destravar também, p'ra ele não se cobrar tanto. Coloca lá na lousa, cada um vai ter que achar este processo". Esta abordagem parece não coadunar com o clássico método de projeto de design, que se inicia com uma ampla fase de pesquisa.

Já o Respondente 2, outro professor, como citado na seção 4.2.1.1, afirmou achar importante um feedback dos alunos a respeito de conteúdos e propostas: "[...] tenho uma preocupação muito grande se a minha performance como professor é aquela que está à altura do que eles precisam. Então, eu penso uma nova metodologia, desconstruo tudo e faço uma coisa nova, eu me permito". Sua fala sugere intenção de contribuir para uma formação de qualidade, mostrando-se atento à necessidade de reajustes e aperfeiçoamentos em seus procedimentos didáticos.

Segundo o Respondente 5, a partir da proposta, afinidades e facilidades de cada um, os alunos, ao se reunirem, perceberiam mais ou menos a situação, o tempo e fragmentariam o trabalho conforme as necessidades, muitos desenvolvendo bem o trabalho, enquanto outros: "[...] ficam tateando para descobrir o mínimo que se tem que fazer. Geralmente, é um grupo com o qual você tem que ter muita clareza com prazos de entrega, controlar bem esse nível 'mínimo' com ficha de avaliação e critério. Não pode deixar vago". Seu relato parece indicar que o desempenho em atividades e/ou projetos estaria diretamente relacionado ao perfil do grupo, sendo pertinente, em determinados casos, ao que sugere o respondente, uma postura mais assertiva do professor. 


\subsubsection{2}

\section{Perspectivas de respondentes associados a escolas da rede Senac-SP}

A Respondente 29, professora, declarou perceber certa dessemelhança quanto ao aproveitamento no grupo. Para ela, a situação envolveria o acesso ao computador: "A gente tem colocado as atividades, tudo em sala, porque isso causou uma diferença muito grande entre os alunos que não têm muita facilidade com o programa, que não têm computador que rode o software ou que não tem computador mesmo". Isso corrobora a visão da Respondente 30 de que: "Teve problema na 'Qualificação 1' com relação ao software gráfico. Porque, tem pessoas que não têm como desenvolver em casa. Não têm uma máquina. Como é que eu vou cobrar?" Sua declaração sugere preocupação dos docentes com a diferença de nível de aprendizado dos alunos, materializada na qualidade dos trabalhos apresentados.

A esse respeito, a mesma Respondente 30 informou necessidade de implementação de acompanhamento mais direcionado. Segundo ela, "Então, começamos a história dos plantões. A gente teve que parar e fazer a recuperação durante a UC. Perceber que o aluno está com dificuldade e vai ficar desnivelado". Comentou, em complemento, que o aluno escolheria o professor e o conteúdo a ser passado em outro dia e horário. "Tem os plantões que são individuais. Mas tem plantão que é dentro da própria sala de aula. Eu acompanho passo a passo e, aí, eles vão tirando as dúvidas". Isto parece indicar, novamente, comprometimento em identificar possíveis dificuldades e auxiliar os alunos durante o processo, seja individualmente ou em horário de aula. Ainda segundo ela, haveria importante sinergia entre alunos mais e menos avançados: "A gente começou a fazer as assistências em sala de aula. Os que têm mais facilidade ajudam os colegas, que acabam aprendendo do mesmo jeito. E o outro 'tá exercitando e gastando energia. [...] Aí, vão criando os vínculos". Esta dinâmica parece contribuir não somente para a diminuição do desnivelamento entre alunos, mas, sobretudo, para a socialização do grupo.

De acordo com a Respondente 32, também professora, haveria mérito em se tentar abordagens mais empíricas, sensoriais e de "mão na massa": "Eu sempre fui das tintas, da massinha, do contar histórias, de pegar repertório de outras áreas. Mas eu não tinha isso com tanta constância. Tenho me forçado a fazer muito mais 
isso, até a sair de ambientes educacionais formais". Isto sugere que essa docente, mesmo já oferecendo aulas diferenciadas, estaria predisposta a intensificar estas atividades, tendo em vista o valor das mesmas para o aprendizado, bem como proporcionar vivências em ambientes fora da sala de aula. Além disso, a respeito do protagonismo dos alunos nas práticas pedagógicas, declarou: "Todas as minhas aulas também dependem dos alunos. Eu não dou aula onde eu passo um PowerPoint e eles têm que responder algo. [...] Se eles não contribuem, não tem aula. É exaustivo, mas é o que eu tenho feito". Este relato sugere o propósito de deslocar o aluno de sua condição de expectador e favorecer uma atitude mais colaborativa em relação à própria aquisição de conhecimento.

Em relação à maneira como a teoria é passada, a Respondente 29, professora já citada, apontou que seria de vários modos: "A gente apresenta a matéria em forma de entrevista, experimentação, exposição, jogo, leitura, palestra, debate etc. Não fica só naquela coisa expositiva". Isto parece revelar preocupação em expor os assuntos de maneira diversificada, procurando, sobretudo, motivar os alunos. Quanto à dinâmica de aula, a mesma Respondente 29 explicitou a importância de os alunos assumirem papel mais ativo em suas práticas pedagógicas. Para ela, "Eles preparam bastante seminário. Tem a básica, a apresentação, mas também tem exposição de vídeo, faz trabalho em grupo e apresenta o trabalho. [...] Mais da metade das aulas eles trabalham no computador". Esta afirmação parece indicar propostas que favoreçam a iniciativa pessoal dos alunos e, mais especificamente, suas habilidades de comunicação, de defesa de ideias e de socialização, porém a produção por meio do computador ainda teria destaque, revelando caráter prático do ensino técnico, em princípio caracterizado por ser mais voltado à formação para o mercado de trabalho.

De acordo com o Respondente 31, outro professor, a dinâmica em classe dependeria da diligência do aluno: "A aula parte de alguma pesquisa pedida ou alguma análise. [...] Não vou explicar como fazer um manual de identidade visual. Os alunos vão ter que pesquisar, no mínimo, três manuais e achar os pontos que são iguais e os que são diferentes". Sua fala parece indicar intenção de promover a investigação, procura e análise de referências. "[...] em cima disso, partem para a criação do logo. Eu passo um briefing do que quero que se crie e deixo duas a três aulas para criação, 
como se fosse uma agência". Esta declaração sugere propósito de simular a vivência de ambiente profissional de trabalho. Quanto à ocasião em que os fundamentos seriam passados, o mesmo Respondente 31 assinalou: "Em produção gráfica é o momento em que a teoria é dada. Eu parto da malha, explico como é, a importância. Dou a teoria conforme o andamento do projeto". Este relato pressupõe cuidado em contextualizar os fundamentos na prática.

\subsection{3}

\section{Conteúdos, abordagens, propostas e atividades desenvolvidas}

Os dados analisados na categoria temática apresentada nesta seção foram separados em subseções correspondentes às duas principais redes de escolas técnicas cobertas pela pesquisa: a Etec-SP e o Senac-SP. Observe-se que, na rede Senac-SP, não há o instituto da disciplina, havendo uma rejeição à ideia de conteúdos que seriam transmitidos aos alunos, pois a escola prefere algo como uma compreensão em torno de eixos temáticos.

\subsubsection{1}

\section{Conteúdos, abordagens, propostas e atividades desenvolvidas} na pedagogia das escolas da rede Etec-SP

Relativo ao lugar de execução de trabalhos, a Respondente 3, professora, informou que, apesar de parte dos alunos da tarde cursar o ensino médio pela manhã, muitos levariam trabalhos para casa. Já os da noite, majoritariamente, realizariam os trabalhos em sala de aula, em virtude de sua jornada laboral diurna. Como afirmou a mesma Respondente 3, sua disciplina seria composta por cinco aulas semanais, o que favoreceria a execução de todas as atividades na escola; além disso, não apreciaria avaliar trabalhos executados sem seu acompanhamento. Já, para o Respondente 5, professor citado, tal escolha dependeria dos próprios alunos. Assim, alguns levariam para casa e outros, por não possuírem computador e/ou aplicativos apropriados, fariam na escola, por isso acrescentou: "Não se pode forçar que seja feito na escola. Eles têm muito recurso hoje de indicar como querem 
flexibilizar as coisas. Eles são muito sensíveis, desistem muito fácil, não é produtivo ficar brigando". Tais relatos, muito diversos entre si, parecem indicar que a escolha por trabalhar na escola ou em casa dependeria de características próprias dos alunos, disponibilidade de equipamentos e de tempo, além de preferência do docente por acompanhar a atividade discente.

\subsubsection{1}

\section{Conteúdos de história da arte}

Em relação a conteúdos, abordagens, propostas e atividades desenvolvidas, a Respondente 25, uma ex-aluna do curso "modular", informou que a disciplina de história da arte seria ministrada em dois semestres, não se restringindo à abordagem teórica. De acordo com ela, "História da arte envolvia exercícios de pintura, não ficou só na teoria. A gente falou de fauvismo e, aí, a gente foi fazer alguma coisa de fauvismo mesmo. [...] tinha história da arte, mas não tinha essa conexão do projeto com a história da arte". Note-se que os fundamentos de movimentos artísticos precederiam as atividades práticas, o que sugere percebido mérito de contextualizar aspectos gerais e situar a proposta antes de se propor algum exercício criativo. Ao mesmo tempo, ao realizar determinada atividade com temáticas relacionadas aos movimentos artísticos recém-apresentados, tais conteúdos pedagógicos, ao que se presume, tenderiam a se consolidar melhor.

A Respondente 28, ex-aluna do Etim, também citou a existência de dois módulos de história da arte no curso técnico. Ao comentar aspectos importantes da história da arte, informou que alguns deles não teriam sido abordados. Segundo ela, "Pensar no estilo e entender que essa pessoa tinha influência de outras coisas, tinha a questão técnica, questão do tempo que ela "tava vivendo, da vida dela e como isso influenciou no trabalho final. Essa série de coisas, nem foi colocada". Sua fala sugere que, possivelmente por estar cursando faculdade de design gráfico, teria uma ideia mais aprofundada de que os movimentos artísticos não teriam surgido do nada, isto é, eles se inseriram em um determinado contexto histórico, afetando o comportamento político-social. 
Por outra perspectiva, a Respondente 23 , também ex-aluna, informou gostar muito das aulas de história da arte no curso técnico, apesar de não se lembrar de muita coisa, mas teria considerado importante uma pequena base de história da arte, uma vez que fora ministrada, também, no $1^{\circ}$ e no $2^{\circ}$ semestres da faculdade de design. Segundo ela, "No técnico, era história do design junto com história da arte, um pouquinho das duas coisas misturadas. Talvez, a carga horária foi muito de história da arte e pouco de história do design em si”. Observe-se que haveria conteúdos de história do design, embora em menor quantidade, se comparados com os de história da arte. Isto parece indicar necessidade de se abordar um pouco mais o estudo de história de design em cursos de comunicação visual.

De modo complementar, a Respondente 24, igualmente ex-aluna, aludindo às aulas de história da arte no curso técnico, mencionou não haver anterior proximidade com tais assuntos. De acordo com ela, "Foi meu primeiro contato com história da arte, porque, no ensino médio, não era o foco. O professor passava por tudo. Foi muito imersivo, a aula era muito boa". Com base em seu depoimento, parece que os ensinamentos de história da arte teriam sido bastante abrangentes e significativos, prendendo sua atenção.

Por sua vez, o Respondente 26, também ex-aluno, relatando as aulas de história da arte no ensino técnico, declarou perceber a abordagem temporal e representativa das principais escolas de arte. Para ele, "Eu tive noção do que eram os movimentos artísticos dentro de um tipo de formato cronológico. [...] A gente olhava de uma maneira muito mais referencial do que se produziu ao longo de história em termos de produção bidimensional, sobretudo". Sua fala pressupõe ênfase desta disciplina em situar os temas abordados dentro de uma linha do tempo, bem como o foco em trabalhos de duas dimensões, possivelmente por se tratar de um curso de design gráfico. Ainda, o mesmo Respondente 26 apontou como se desenrolariam as aulas: "A gente assistia as aulas expositivas do professor, que mostrava o que se produziu em cada época na história da arte. Tinha esse movimento, nesses parâmetros e se produzia isso. A gente via muita imagem na aula, muita coisa". Este fragmento sugere intenção de expor os alunos a grande quantidade de referências visuais, buscando, ao que se presume, formação de repertório. 


\subsubsection{2}

\section{Instrução de aplicativos gráficos}

Para o Respondente 4, professor da disciplina "Aplicativos Informatizados em Design Gráfico", a proposta de sua matéria seria capacitar os alunos para utilizar e montar o trabalho no programa. "Vou dando algumas noções de criação, de processo. Não é só a utilização do software, não é o resultado do comando, mas aplicado ao mercado de trabalho". Esta fala sugere preocupação do professor em oferecer aos alunos a possibilidade de adquirir competência para atuação em situações reais de trabalho. Segundo ele, a ilustração digital seria executada no Photoshop ou no Illustrator: "[...] Depende do resultado que você quer. No Illustrator, o resultado é muito 'chapado', difícil de sombrear. O Photoshop dá mais volume". Esta declaração parece indicar conhecimento do docente quanto às características próprias de cada aplicativo, em função da proposta e valorização de aplicativos que forneçam a expressão visual de volumes tridimensionais.

A Respondente 25, ex-aluna, aludindo ao aprendizado de aplicativos gráficos, informou que, na graduação, não seriam ministrados. Segundo ela: "É o conteúdo e você que se vire. O que, no técnico, tinha. [...] eram programas da Adobe: Illustrator, InDesign e Photoshop. [...] Aplicativos teve em dois módulos. É uma coisa que eles aprofundam". Note-se que não haveria aulas de aplicativos na graduação e que as aulas no curso técnico desta disciplina seriam detalhadas e ministradas em dois módulos, sugerindo que os conhecimentos e habilidades desenvolvidas em aplicativos gráficos por alunos provenientes de cursos técnicos de comunicação visual possibilitariam melhor desenvoltura, em relação a seus colegas de faculdade, na execução de determinadas atividades de projeto na graduação.

De outro ponto de vista, a Respondente 23, em se tratando de seu aprendizado em aplicativos gráficos no curso técnico em que estudou, considerou não haver aprendido muita coisa. Para ela: "[...] me deu um parâmetro p'ra usar o Pacote Adobe:

o Photoshop, o lllustrator e o InDesign, um pouquinho. No técnico, me deu a base, mas, eu aprendi muito mais sozinha, fazendo freelancer etc., ou mesmo na faculdade, com colegas". Isto sugere que a carga horária e o grau de imersão em conteúdos de programas de computação gráfica seriam insuficientes para que os alunos atinjam grau de proficiência considerado compatível com as exigências de mercado. 
Similarmente, a Respondente 27, ex-aluna do Etim, relatando os aplicativos gráficos apresentados nos dois primeiros anos, também declarou ter aprendido muito pouco. Segundo ela: "No $1^{\circ}$ ano, a gente aprendeu a mexer nas coisas mais básicas do CorelDraw. No $2^{\circ}$, [...] deveria ter Illustrator, mas nossa professora estava de licença e os alunos do outro ano começaram a ensinar a gente, mas foi uma coisa bem jogada". Observe-se que os estudantes dessa escola teriam permanecido, por muito tempo, sem professor de aplicativos gráficos e que alunos mais velhos procuraram ensinar os mais novos. Isto pressupõe falta de atenção em substituir devidamente um professor ausente, propiciando o comprometimento desse aprendizado.

Por outra perspectiva, a Respondente 28 , também ex-aluna do Etim, relatando as aulas da disciplina "Aplicativos Informatizados em Design Gráfico", informou que teriam sido bem entediantes, uma vez que já ingressara no curso sabendo diversas coisas; apesar disso, mencionou a importância de algumas orientações recebidas. Segundo ela: "[...] me foi apresentado uma maneira ortodoxa, algo que segue uma linha de raciocínio, com começo, meio e fim. Como se cria um arquivo, toda aquela diretriz. Já, se é p'ra tela, se é p'ra impressão, tem que ter ' $X$ ' de resolução, esse guia básico". Isto sugere atenção dos professores em informar os alunos a respeito de procedimentos essenciais para um adequado desenvolvimento de atividades projetuais em meio digital.

\subsubsection{3}

\section{Noções de desenho geométrico}

A Respondente 23, ex-aluna, recordando aulas e atividades no curso técnico, mencionou algumas particularmente relevantes. De acordo com ela, "Lembro da aula de desenho geométrico e, também, de construir embalagens [em papel cartonado] a partir desses desenhos: hexaedro, octaedro. [...] Nem na faculdade eu tive uma aula tão boa de geometria quanto eu tive no técnico". Esta afirmação denota que os conteúdos e as atividades propostas nas aulas de desenho geométrico do curso técnico de comunicação visual, assim como a didática do responsável por essa disciplina, seriam muito valorizados por esta respondente.

De outro ponto de vista, a Respondente 25, outra ex-aluna, em relação à disciplina de desenho geométrico, mencionou a diferença de abordagem entre os cursos 
técnico e superior. Para ela, "[...] a gente ficou só nas formas geométricas, como fazer essas formas no tridimensional. Mas, na faculdade, 'tá mais ligado a planos, diedros, construção mesmo da forma [...]. Como usar nos softwares os diedros, como rebater os planos". Este fragmento pressupõe que a ênfase do desenho geométrico no curso técnico seria o aprendizado de processos para a construção de figuras geométricas no plano e de sua estruturação no âmbito tridimensional. Ainda, a respeito de outra proposta nesta disciplina, a mesma respondente comentou ter achado superficial e, de acordo com ela, "A gente fez embalagem também nessa matéria. Era um tamanho reduzido, não fizemos teste nem nada. Bem rasinho mesmo". Note-se que não haveria teste na realização da embalagem. Isto sugere falta de menção ao método de projeto de design no curso técnico.

A Respondente 28, uma ex-aluna do Etim, também comparando o desenho geométrico lecionado no curso técnico e o ensinado na graduação, apontou diferenças de perspectiva. Segundo ela, na faculdade: "[...] você faz a linha. Você tinha que puxar não sei o quê e tinha que usar o esquadro e eu não sabia usar. Você meio que via o objeto de cima e, aí, projetava ele no papel. Era o maior 'rolê' na parte de cima da folha. Eu nunca soube usar aquilo". De acordo com seu depoimento, a respondente não aprendera, no curso técnico, a utilizar instrumentos básicos de desenho, tampouco processos para construção de figuras geométricas. A respeito do aprendizado de desenho em perspectiva, no curso técnico, a mesma Respondente 28 informou que: "[...] a perspectiva foi: 'então, dois prédios longe, eles ficam menores. E um prédio mais perto, ele é maior'. Aí, tem as linhas e acabou". Esta fala sugere que a abordagem do ensino de perspectiva nos cursos técnicos pareceria superficial, o que seria especialmente crítico em se tratando do ensino de comunicação visual.

\subsubsection{4}

\section{Introdução a elementos de tipografia}

A Respondente 25, ex-aluna, aferindo o estudo da tipografia no curso técnico, informou considerá-lo muito teórico. Para ela, "O professor começou falando dos hieróglifos, ele entrava bem na história da tipografia, nos alfabetos, na variação, até chegar no nosso alfabeto, como foi o processo p'ra formar, por exemplo, a letra 'A'". Esta fala sugere ênfase histórica nas aulas de tipografia. Quanto à parte mais 
prática, a mesma Respondente 25 informou ter realizado duas atividades: "A gente desenhou todo o alfabeto, só que era muito iniciante mesmo. Depois do alfabeto, a gente fez um cartaz com ele. [...] Não ensinou coisa de kerning, essas coisas que a gente usa hoje em dia. Era mais fazer as letras". Observe-se que haveria muitas aulas teóricas, porém a conceituação de espaçamento entre letras adjacentes não foi mencionada. Isto sugere falta de atenção na abordagem de conceitos importantes que atuam na legibilidade. Já a proposta de utilização desse alfabeto na realização de um cartaz, revela intenção de promover competência criativa em peça informacional, relevante à área do design gráfico.

De modo complementar, a Respondente 23, outra ex-aluna, recordando disciplinas do curso técnico, citou as aulas de tipografia e de encadernação. Para ela: "Lembro de história da tipografia e encadernação, com outro professor. [...] Um pouquinho do que eu vi da história da tipografia no ensino técnico, eu também vi, um pouquinho na faculdade. Eu já sabia um pouquinho do que "tava sendo dito". Esta declaração sugere valorização do aprendizado histórico da tipografia no curso técnico, o que contribuiria para um posterior estudo dessa respondente na graduação em design.

De modo diverso, a Respondente 27, também ex-aluna, informando a respeito do estudo da tipografia em seu curso técnico, declarou que teria sido muito superficial. Segundo ela: "Na minha escola, a gente escutou sobre tipografia, que era uma técnica usada sei lá quando... Gutemberg". Este breve depoimento sugere que a tipografia, reconhecida como estudo, criação e aplicação de caracteres, estilos, formatos e arranjos visuais de palavras, fundamental na área da comunicação visual, haveria sido apenas mencionada. Quanto a atividades alusivas à tipografia, a mesma Respondente 27 informou a proposta de um livro infantil de alfabetização, realizado no $1^{\circ}$ ano. De acordo com ela, "[...] tinha que fazer um alfabeto meio ilustrativo. [...] Era p'ra chamar a atenção da criança querer aprender isso. O tema era bem aberto. No $2^{\circ}$ ano, foi mais direcionado. Era um alfabeto que tinha que ser ilustrativo, com comida ou alguma coisa assim". De acordo com esta declaração, parece que os fundamentos da tipografia e do design de tipos não teriam sido ministrados, sugerindo ser uma atividade mais experimental, ilustrativa, mais relacionada às artes visuais do que propriamente ao design. 


\subsubsection{5}

\section{Elementos de teorias da cor}

Segundo a Respondente 3, responsável pelas disciplinas "Formas Expressivas Bidimensionais" (FEB) e "Formas Compositivas de Elementos Plásticos" (FCEP), no primeiro módulo declarou ter proposto exercícios para o desenvolvimento das técnicas de nanquim aguado e lápis aquarelado e, no segundo semestre, exercícios de observação e técnicas de guache, aquarela e acrílica. Para ela: "A técnica da acrílica é mais fácil do que aquarela porque, quando você erra, você vai por cima, aquarela não tem como fazer isso. Acrílica é pouquíssima água, então, o papel já não vai ficar ondulado que nem com aquarela". Esta passagem revela domínio da respondente quanto a técnicas de pintura. A mesma Respondente 3 relatou que, ao propor pintura de paisagem em acrílica sobre tela, daria exercícios em papel canson: "Quando chegar mais próximo, eu peço p'ra eles saírem de semana e fazer uma foto de um espaço verde qualquer. Eles vão fazer essa pesquisa. Eles veem e reproduzem, cada um a sua", citando que, apesar de a maioria dos alunos apreciar tais disciplinas: "[...] tenho três que não gostam, porque eles entraram aqui p'ra fazer comunicação visual". Esta observação sugere que o aprendizado de técnicas de pintura, isto é, abordagem mais empírica, de "mão na massa", não corresponderia ao ideário de alguns alunos a respeito do que seria aprendido em comunicação visual.

No que se refere ao estudo da cor, a Respondente 25, ex-aluna, relatando as aulas deste assunto no curso técnico, mencionou que seriam especialmente dinâmicas. Segundo ela, "Era pintar mesmo. Fazer caderno de pintura, fazer escala, a gente aprendeu bastante coisa nessa matéria. [...] usou tinta mesmo (TGA) p'ra falar de cor. Falou de impressão, mas ficou mais p'r'o $3^{\circ}$ semestre, p'r'o TCC mesmo, de cor impressa". Este fragmento parece indicar que o aprendizado das cores, nos dois primeiros módulos do curso técnico, seria essencialmente prático - uma abordagem mais empírica, de "mão na massa" - e que o estudo da cor impressa seria reservado para o último módulo, correspondendo ao desenvolvimento do TCC.

De modo complementar, a Respondente 23, outra ex-aluna, mencionando os exercícios cromáticos como sendo relevantes para o entendimento das cores, notou semelhança entre tais trabalhos no curso técnico e na graduação. De acordo com ela, "A abordagem do círculo cromático e fazer escala de cor era muito 
parecida. Eu lembro que, às vezes, era um pouco entediante, porque eu 'tava fazendo de novo, com o mesmo TGA [...] comprado no técnico, o mesmo exercício na faculdade". Sua fala sugere que as habilidades desenvolvidas por meio de exercícios cromáticos no curso técnico possivelmente contribuiriam para melhor desempenho na graduação.

Completando essa visão, a Respondente 28, também ex-aluna, ao citar os exercícios realizados com tinta TGA nas aulas de FCEP (Formas Compositivas de Elementos Plásticos) no curso técnico, revelou sua importância para a realização de trabalhos de cor na graduação. De acordo com ela, "Me salvou muito quando eu fui fazer na faculdade. A gente teve que fazer aquelas escalas. Pelo o que eu já tinha vivido lá atrás, eu sabia de tudo o que eu não tinha que fazer. [...] Todos os atalhos de como fazer melhor a escala". Este depoimento sugere relevância da abordagem prática de exercícios de cor do curso técnico ao propiciar adequada desenvoltura em atividades semelhantes na graduação em design gráfico.

Quanto ao estudo teórico da cor, a mesma Respondente 28 qualificou, como especialmente expressivas, as aulas a respeito da psicologia da Gestalt. Para ela, "Teve a cor, que me ajudou na aula de teoria da cor na faculdade. [...] Coisas da Gestalt mesmo. Obviamente, quando você 'tá no [curso] técnico, ninguém te 'pega no pé' por causa de um negócio desse, porque é extremamente complexo". Sua fala parece indicar mérito do curso técnico em apresentar, aos alunos, os fundamentos do sistema de leitura visual da forma do objeto. Pressupõe, também, que o nível de exigência desse assunto seria diferente no ensino técnico e na graduação.

\subsubsection{6}

\section{Introdução à fotografia}

A Respondente 28, ex-aluna, ao comentar as aulas marcantes no curso técnico, citou a disciplina de fotografia como especialmente formativa e inspiradora, uma vez que: “[...] foi muito proveitosa a aula de estúdio. [...] P'ra um designer, que não vai se aventurar nesse campo, deu uma base mais que suficiente p'ra ter autonomia, produzir suas próprias imagens. A gente ia aprendendo técnica, a parte teórica da máquina". Esta declaração parece indicar que os princípios básicos relativos ao funcionamento do equipamento fotográfico e a apresentação de determinadas 
técnicas seriam percebidos como relevantes para essa respondente em sua formação em design. Sugere, também, adequação pedagógica no aprendizado destes conteúdos.

Ainda, a mesma Respondente 28, comentando diferentes modalidades, finalidades, técnicas e linguagens da fotografia, realçou a importância de haver sido exposta a esses conteúdos. De acordo com ela, "Teve fotografia de comida. [...] A noção de você montar, com base em uma foto, corrigir a foto, montar, até se aproximar do que você quer. [...] Mais p'ra frente, teve fotografia publicitária. [...] Eu curto muito foto não, mas as aulas eram boas". Observe-se que essa respondente, mesmo declarando não gostar muito de atividades ligadas a fotografia, relatou, com entusiasmo, todas as etapas dos processos de que participou. Isto sugere seu interesse pelas aulas e a probabilidade elevada de que hajam sido adequadamente ministradas.

De maneira complementar, o Respondente 26, outro ex-aluno, relatando algumas experiências em aulas de fotografia, declarou não terem sido proveitosas. Para ele, "O professor de fotografia olhava muito mais a disciplina como voltada p'ra fotografia, em si, do que orientada p'r'o curso de design. Ele ia escrevendo na lousa textos sobre fotografia e a gente tinha que copiar. Só no final, a gente foi mexer na máquina". Esta fala parece indicar ausência de conexão desta disciplina com os objetivos do curso de comunicação visual. Pressupõe, também, que talvez este não seria o método mais adequado de ensinar uma disciplina, a qual, supostamente, apresentaria características mais práticas, lúdicas e estéticas.

Já, a Respondente 24, também ex-aluna, mencionando a disciplina de fotografia, informou que seria ministrada em dois semestres e que haveria uma estrutura adequada para sua prática. De acordo com ela, "Tinha um 'lab' de fotografia, todo escuro, reservado, com máquinas. No $1^{\circ}$ semestre, o professor [...] queria exercitar a fotografia, o olhar. No $2^{\circ}$, a gente aprendia a técnica e ia p'r'as máquinas. A gente tinha que levar revelado, p'ra discutir". Isto sugere mérito do professor em promover a percepção visual dos alunos antes de propor exercícios em laboratório. Além disto, ao pedir as fotografias ampliadas para serem apresentadas, pressupõe atenção em favorecer discussão em sala. 
De outro ponto de vista, a Respondente 23, outra ex-aluna, versando a respeito do conhecimento adquirido nas aulas de fotografia no curso técnico, descreveu-o como valioso. De acordo com ela, "[...] eu tive a base no técnico, fui fazer meus trabalhos pessoais e, quando eu entrei na faculdade, eu já tinha esta noção melhor. Não foi exatamente por causa do técnico, mas por causa deste tempo que eu fiquei trabalhando p'ra mim mesma". Observe-se que as aulas de fotografia do ensino técnico teriam servido de alicerce para essa respondente seguir sozinha. Isto sugere que os conhecimentos de fotografia, antes de seu ingresso na faculdade, teriam sido créditos, em parte, do curso técnico e também de sua prática pessoal.

\subsubsection{7}

\section{Elementos de composição visual}

A Respondente 23, recordando alguns exercícios desenvolvidos no curso técnico, mencionou os de composição. De acordo com ela, "Lembro, também, de exercícios de composição com formas geométricas, com a mesma professora [de teoria da cor]". De modo complementar, a Respondente 28, também ex-aluna, ao se recordar das aulas de FCEP (Formas Compositivas de Elementos Plásticos), mencionou as atividades de ilustração. Segundo ela, "Lembro das aulas de ilustração mais manual. Era algo de composição. A gente teve ideia de Gestalt, teoria da cor. Era bem mais analógica". Estes depoimentos sugerem que algumas abordagens em exercícios de composição apresentariam características mais manuais, empíricas, de proximidade com a área das artes plásticas.

Por seu turno, a Respondente 27, igualmente ex-aluna, também informou haver tido atividades de composição. Para ela, "A gente fazia composição. Colocava lá a maçã, a xícara, a pera e ficava desenhando com tinta. Foi mais mexer com tinta". Note-se que a proposta seria exercitar desenho de observação e aprender técnicas de pintura. Isto sugere, assim como nos casos das Respondentes 23 e 28, atividades empíricas, mais "mão na massa", típicas do campo das artes plásticas. Já a Respondente 25, outra ex-aluna, ainda a respeito de atividades de composição, informou terem-na auxiliado quando ingressou na faculdade de design. Segundo ela, "As aulas de diagramação mesmo, composição me ajudaram bastante também, a ter mais noção de diagramar e compor imagens e texto". Esta fala parece indicar que determinados 
exercícios de composição teriam contribuído para o desenvolvimento de competências dessa respondente, percebidas como significativas no campo do design.

Outra perspectiva apresentou o Respondente 26, também ex-aluno, comentando acerca de alguns exercícios do curso técnico, percebidos como particularmente relevantes, em especial, reportou os exercícios de composição visual. Segundo ele, "Eu carrego muito do que eu faço aqui do que a professora me ensinou, lá no [curso] técnico. De composição mesmo, qual é o local mais adequado p'ra colocar cada elemento numa página, é uma coisa que, às vezes, a gente não tem na faculdade". Esta fala sugere que os exercícios de composição desenvolvidos durante o curso técnico de comunicação visual teriam sido incorporados à sua bagagem formativa.

\subsubsection{8}

\section{Projetos de programas de identidade visual}

O Respondente 6, professor da disciplina "Concepção e Representação da Identidade Visual" (Criv), informou como relevante o entendimento dos alunos a respeito da teoria das formas e das cores para a criação de marcas, que atenda aos interesses de um determinado cliente: "Se eles forem desenvolver uma marca, saber como essa marca vai passar a intenção da atividade do cliente. Não é simplesmente criar um logotipo p'ra ser bonito e legal. Tem que ter uma intenção por trás". Deste modo, ao ministrar a disciplina, apresentaria exemplos de marcas bem-sucedidas e consolidadas, bem como referências de marcas não tão eficientes, sendo esse conhecimento importante, também, para se evitar plágio ou lugar-comum. Na sequência, seria proposto o desenvolvimento de um logotipo ou marca com determinado propósito. Esta fala sugere disposição em entender o "perfil da atividade do cliente", mas parece não haver alusão ao usuário, isto é, ao destinatário final do projeto.

A Respondente 24, ex-aluna, com respeito a um exercício proposto no curso técnico, comentou que se relacionaria à identidade visual. Segundo ela, "Fiz mascote, era meio que uma experiência de branding. [...] tinha uma 'pegada' muito mais prática. Ponto de venda, cores que chamam a atenção que, no final, no mercado, você precisa saber se você for p'ra parte gráfica publicitária”. Note-se que a criação de mascote seria bastante alusiva à questão ilustrativa. Isto sugere que algumas propostas seriam mais especialmente relacionadas ao universo das artes plásticas. 
Por sua vez, a Respondente 27, também ex-aluna, relatou outras propostas relativas à identidade visual. De acordo com ela, "A gente teve que fazer uma marca pessoal. Podia ser uma marca p'ra gente como designer gráfico ou qualquer profissão que a gente gostaria de ter. A gente tinha que criar o logo e o manual falando porque que escolheu aquilo". Esta fala sugere atenção em informar a necessidade de se justificar o processo criativo. Pressupõe, ainda, mérito em se propor atividades que promovam integração de conteúdo com a prática profissional.

Já a Respondente 25, outra ex-aluna, relatando a própria percepção a respeito do Curso, comentou que seria bastante voltado para o design gráfico. Segundo ela, "[...] mais p'ra identidade visual, fazer marca. Tanto que, o TCC, eles escolhiam o tema e era sempre fazer uma marca p'ra alguma entidade. Era o mesmo cliente p'ra todos os grupos. [...] Tinha um pouco de embalagem, mas sempre voltado p'ra 'IV'." Observe-se que o tema do TCC se apoiaria na criação ou no redesign de logotipo de alguma instituição e demais aplicações; além disto, outras atividades, como projetos de embalagens, também estariam vinculadas a esta questão. Isto sugere ênfase do curso no desenvolvimento de identidade visual.

Complementando tal visão, o Respondente 26, outro ex-aluno, ao relatar suas preferências, também informou perceber o destaque do curso no desenvolvimento de marcas. De acordo com ele, "A parte de branding, eu não achava incrível, mas gostava um pouco também, mas eu não me via trabalhando, produzindo isso. Boa parte do curso era voltado para o branding, p'ra você desenvolver marcas". Esta declaração denota, uma vez mais, foco do Curso Técnico em Comunicação Visual em projetos de identidade visual.

\subsubsection{9}

\section{Noções de marketing}

A Respondente 25, ex-aluna, comentando a percebida falta de aprofundamento em conteúdos de design no curso técnico, assinalou as aulas de marketing. De acordo com ela, "É um pouco variado. A gente tem aula de marketing, uma coisa meio propaganda. Acho que é mais voltado p'ra questão do mercado, se atende a ele razoavelmente". Este depoimento sugere ideia de que o marketing estaria muito 
mais relacionado ao campo da propaganda do que ao do design. Em contrapartida, a Respondente 27 , outra ex-aluna, relatando uma das aulas do $2^{\circ}$ ano, reportou-se à de marketing. Para ela, "[...] era p'ra aprender a produzir peças gráficas voltadas p'r'o lado publicitário, como atingir um público, como saber qual é seu público, como traçar esse perfil e como fazer peças direcionadas p'ra esse perfil específico que você "tá trabalhando". Note-se que o termo "público" seria utilizado com frequência e o projeto teria, como base, prévia identificação de determinado público. Isto sugere ideia de usuário e, ainda, proximidade dos conteúdos com o universo da publicidade.

De modo complementar, a Respondente 24, outra ex-aluna, mencionando a percebida intensidade do curso técnico, relatou algumas abordagens. Para ela, "Tinha muito o quê conversar e muita apresentação. Falar na frente das pessoas. Muitos seminários também. Em marketing, como não tinha como ficar fazendo exercícios de marketing, era seminário". Observe-se que a proposta em marketing seria a apresentação de seminários. Isto sugere que os conteúdos de marketing seriam basicamente teóricos.

\subsection{0}

\section{Produção manual de modelos físicos de representação tridimensional}

A Respondente 27, uma ex-aluna do Etim, relatando uma atividade desenvolvida no curso técnico, declarou não entender a finalidade da proposta. De acordo com ela, "[...] era p'ra fazer mockup, tipo um hambúrguer grande com isopor ou biscuit. [...] Acho que era p'ra aprender a trabalhar com o material" (figura 23). Esta declaração sugere valorização de atividades manuais de construção de modelos, ainda que com repertório formal e uma linguagem não exatamente condizente com atividades de projeto de design.

\subsection{1}

\section{Noções de animação digital e de construção de sites}

Para o Respondente 5, outro professor de "Aplicativos Informatizados em Design Gráfico", mas do terceiro módulo, os conteúdos práticos de sua disciplina seriam, além do desenvolvimento de materiais gráficos (tais como: revistas e embalagens), também a parte digital (animação bidimensional e site). Em relação a este último: "[...] a parte de site é a mais complicada porque você tem que entrar com algumas 
estruturas de comando, de lógica, e não é todo mundo que tem facilidade com isso". Buscando minimizar tal situação, relatou que, nos grupos, cada aluno assumiria a área de maior afinidade. Segundo ele, a parte técnica seria a mais fácil: "[...] quando entra no interpessoal, no trabalho em equipe, é sempre mais difícil. Alguns atritos, algumas discussões, negociações de todo tipo. Às vezes, as pessoas contam com outras que não correspondem, prometem coisas que não cumprem, o normal". Nesse sentido, a proposta do trabalho em grupo parece sugerir propósito em proporcionar situações do cotidiano profissional, nas quais a atenção ao interpessoal seria relevante.

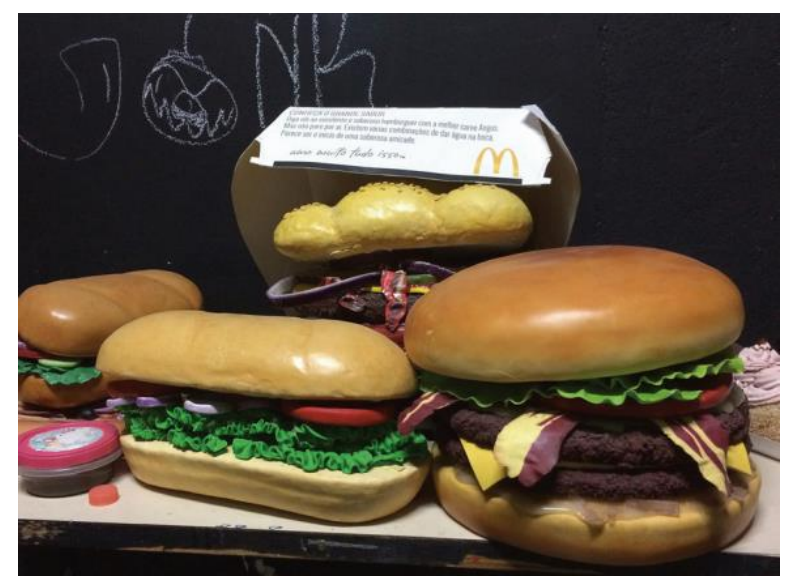

figura 23:

mockup representando sanduíches

Ainda, o mesmo Respondente 5 informou interesse em ministrar conteúdos de vídeo. Segundo ele, para animação digital: "[...] eu tenho focado no 'Flash', mas, eu acho que seria interessante incorporar alguma coisa de vídeo". Isto sugere intenção do professor em proporcionar outros conhecimentos digitais com recursos de produção e edição de vídeos, habilidades bastante valorizadas por jovens. Contudo, como tal módulo corresponderia ao TCC, acreditaria ficar um pouco difícil, pois, de acordo com ele, "Tudo depende da turma. Em um semestre, uma determinada estratégia pode dar certo. Com outra turma, em outro momento, pode ser uma desgraça”. Uma possível razão para explicar este receio do professor seria a elevada dissemelhança de interesses de turma para turma, tornando difícil prever os resultados de uma nova proposta, sugerindo, portanto, ocorrência de variação na composição média das turmas de ano para ano. 


\subsection{2}

\section{Visitas técnicas}

A Respondente 1, professora, citou que as visitas técnicas sempre tiveram destaque dentre as atividades extras. Segundo ela, "A gente é cliente de carteirinha do CCBB [Centro Cultural Banco do Brasil], vai em tudo". Mencionou, ainda, a visita a uma exposição de cartaz no MCB [Museu da Casa Brasileira] como sendo muito importante em termos pedagógicos, na medida em que se alinharia com atividades propostas no Curso: "Aqui a gente está expert em cartaz, é a grande mídia do design gráfico. A gente faz cartaz ao type, cartaz com fotografia, cartaz com ilustração". A este respeito, o Respondente 2, aluno, relatou apreciar bastante tais visitas técnicas: "A gente não precisa estar dentro da aula p'ra aprender". Sua fala sugere mérito das escolas da rede Etec em expor seus alunos a conteúdos para além das dependências escolares, proporcionando conhecimentos e vivências significativas.

A mesma Respondente 1 ainda destacou, como relevante, a chamada "Semana de Comunicação Visual", uma semana inteira dedicada à atualização do curso, compreendendo palestras, visitas técnicas, workshops, conduzidos por profissionais da área, entre os quais, ex-alunos do Curso: "A gente espera que o aluno possa interagir com esse palestrante". De modo complementar, a Respondente 7, também professora, relatou a existência de dois outros eventos anuais denominados "Semana Paulo Freire" e "Semana Tecnológica", em que palestras seriam proferidas por convidados externos, muitos deles egressos do Curso, ocasiões em que também seriam expostas as produções dos trabalhos de alunos. Estes depoimentos revelam a importância destes eventos em manter os discentes em sintonia com o que estaria sendo produzido no campo. Sugerem também, que, ao convidar ex-alunos para apresentarem suas experiências profissionais, estariam incentivando os alunos ativos para atuação na área. 


\subsubsection{2 \\ Conteúdos, abordagens, propostas e atividades desenvolvidas na pedagogia das escolas da rede Senac-SP}

O Modelo Pedagógico Senac considera a competência o ponto central do currículo dos Cursos Técnicos, sendo a competência a própria unidade curricular (UCs), distribuídas em Qualificações Técnicas Profissionais (QTPs). Quanto as declarações de ex-alunos, à época em que cursaram, ainda era estruturado em módulos.

Em relação aos conteúdos, abordagens, propostas e atividades desenvolvidas, o Respondente 34, aluno, mencionou o manual de identidade visual que estaria sendo realizado, destacando a quantidade de etapas que envolveria sua execução: "A gente pesquisou e tinha que produzir uma identidade visual p'ra uma empresa. Falar o conceito da marca, o público-alvo, a tipografia que é p'ra ser usada e o que não usar na identidade. [...] É bem complexo". Ao instruir os alunos de que o ponto de partida seria uma pesquisa para obtenção de conteúdos básicos de um manual de identidade visual, sugere intenção de informar o valor de se obter referências antes do início de qualquer projeto, facilitando o desenvolvimento das etapas subsequentes.

De modo análogo, o Respondente 33, outro aluno, citou o projeto de criação de uma editora. "Fazer toda a identidade visual, trabalhar desde o nome até o produto final que você produz lá dentro, a identidade como um todo. Porque isso reflete muito no que a gente vai fazer no mercado de trabalho". Este apontamento sugere compreensão da importância de serem expostos a projetos abrangentes de identidade visual e sua relação com a prática profissional.

Similarmente, a Respondente 37, ex-aluna, também mencionou propostas relacionadas à identidade visual. Segundo ela, no primeiro módulo: "[...] era fazer o portfólio, escolher um tema, no sentido de uma identidade visual: minimalismo, art noveau, algo voltado p'r'o visual. [...] Eu fiz sobre pop art. [...] Tinha que fazer um logo também p'r'a gente". Esta fala pressupõe intenção de apresentar aos alunos fundamentos de movimentos artísticos, bem como preceitos de construção de elementos gráficos e visuais para comunicar conceitos e valores. Quanto ao segundo módulo, a mesma Respondente 37, relatando o percebido progresso de todos, 
informou outro projeto envolvendo identidade visual: "No segundo módulo, o manual de identidade visual foi mais tranquilo, porque a teoria que a professora foi passando, no primeiro módulo, foi surtindo mais efeito". Esta fala sugere que conceitos teóricos ministrados anteriormente haveriam sido interiorizados, promovendo maior capacitação para desenvolvimento do projeto subsequente. Em relação aos conteúdos dos demais módulos, a própria Respondente 37 informou: "A revista [terceiro módulo] eu lembro e a embalagem [quarto módulo] eu também lembro, que a gente teve bastante teoria". Este fragmento pressupõe que haveria fundamentação teórica servindo de base para a realização de projetos em módulos mais avançados.

Por seu turno, a Respondente 36, outra ex-aluna, comentando os conteúdos percebidos como significativos, destacou o aprendizado de determinados aplicativos gráficos: "No técnico, além do Illustrator, aprendi um pouco de Photoshop, Corel e InDesign. [...] Tive algumas aulas sobre encadernação e processos gráficos também, que são sobre impressão. Era sobre papel, sobre tipo de impressão". Esta declaração sugere mérito em expor aos alunos conteúdos que não se restrinjam à fase de criação de um projeto gráfico propriamente dito, mas também questões a respeito de sistemas de impressão mais adequados à natureza de cada projeto, considerando tipo de papel, cores e acabamentos utilizados.

Já o Respondente 35, outro aluno, destacou, como relevante, as abordagens variadas de apresentação de conteúdos. Segundo ele, "Uma aula mostra um vídeo, outra aula a gente foi em uma exposição de fotografia fora. É algo que já tem uma outra experiência. [...] Uma coisa bem legal são essas apresentações.

Faz um trabalho e tem que justificar todo ele". Seu relato parece indicar entendimento de que atividades diversificadas possibilitariam vivências singulares. Sugere, ainda, compreensão de que justificar projetos estaria contribuindo para formação crítica tanto na área do design quanto no âmbito pessoal.

Em relação aos conteúdos abordados no Curso, o Respondente 33, aluno já citado, informou haver exercitado diversificados trabalhos: "A gente aprendeu a fazer muita identidade visual, desde o logo quanto informação de um cardápio, informação de um site. [...] Um banner que você vê na rua, aqueles que têm no metrô. Um anúncio de um celular novo, um filme, qualquer coisa". Sua declaração sugere atenção 
em expor os alunos a ampla gama de conteúdos, possibilitando formação mais completa. O mesmo Respondente 33 citou, ainda, outros conteúdos abordados: "A gente trabalhou muito, também, com sinalização. [...] fazer ícones p'ra sinalizar as coisas, que é bem interessante. [...] vai começar a entrar na parte de imprensa, diagramação. Que é organizar livros, jornais, revistas, tudo mais". Seu depoimento, além de apontar vários conteúdos pertinentes à área do design gráfico, parece indicar satisfação desse respondente com o que estaria sendo proposto.

Quanto a propostas de exercícios, a Respondente 30, professora, mencionou o projeto de cartas de baralho: "Tem que estudar ícone alfabético, sinal não alfabético. Dentre vários movimentos, eles escolheram pela natureza qualitativa do grupo. Um seria o 'ornamental', o exagero, o 'funcional', algo mais 'flat' e o 'expressionismo', grita com traço e cor" (Figura 24). A mesma Respondente 30 acrescentou que este trabalho corresponderia à primeira etapa do PI [Projeto Integrador]. Tal preocupação denota intenção de, a partir do entendimento das características visuais específicas de cada movimento artístico, aplicá-las para simbolizar um projeto.

Informou ainda, a mesma Respondente 30, que a segunda etapa do PI envolveria a criação do logo da editora, responsável pela produção do baralho e execução do manual de aplicação de tal logo, como também citado na seção 4.3.1.2. Para ela, "Essa aula eu boto prancheta, eles começam a criar. Eu vou trabalhar com massa de modelar. Eles vão modelar mesmo a tipografia e o símbolo. Eles me deram o conceito, rascunharam quatro ou cinco propostas" (Figura 25).

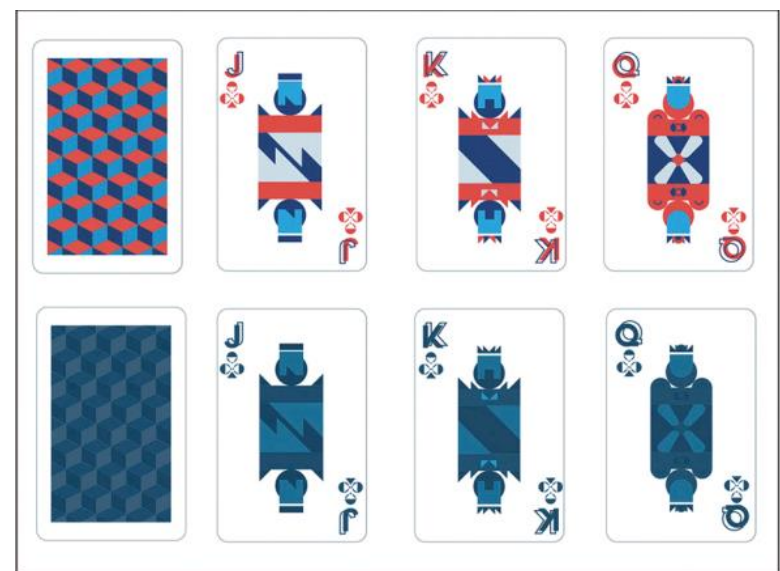

Figura 24:

projeto de cartas de baralho

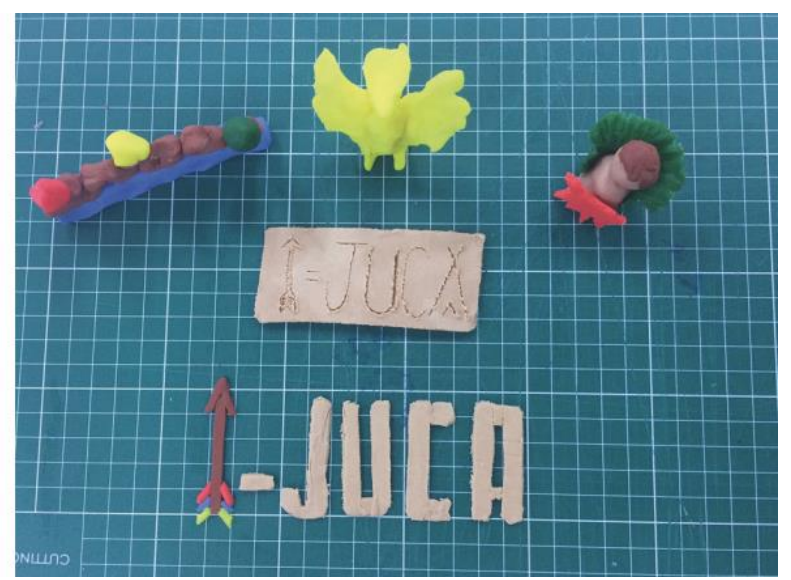

Figura 25:

logotipos, símbolos gráficos (massa de modelar) 
Isto parece indicar atenção em expor o grupo a ambientes e materiais menos convencionais, em abordagens também alternativas, que estimulem habilidades sensoriais, motoras, cognitivas e sociais.

A própria Respondente 30 relatou que, em tal etapa, os alunos iriam aprender malha construtiva, família de fontes, paleta de cor, aplicabilidade, regra p'ra sinalização, além de simular boneco e material de escritório. Isto parece indicar que os alunos estariam sendo apresentados a conteúdos e questões básicas do design gráfico, condizentes com sua prática em técnicas e, ao que se presume, mais especialmente estimulantes. Com relação à abrangência deste projeto, a Respondente 30 realçou que: "Esse PI vai reverberar lá na frente [na QPT Programação Visual de Design Promocional], porque eles vão fazer técnicas de embalagem e suporte p'ra ponto de venda. [...] Vai ser o grande Pl". Tal afirmação sugere que este projeto, ao alimentar duas QPTs, evidenciaria o caráter transversal do design.

A mesma Respondente 30 mencionou a importância de o tema gerador proposto ser criteriosamente escolhido, relatando o que ocorrera na primeira QPT, "[...] o tema criativo sugerido era qualidade de vida versus "burnout ${ }^{12}$. É uma síndrome que você começa seu dia já sem carga energética. [...] O tema absorveu. Eles ficaram empáticos. Era produção gráfica, eles tinham que criar cartazes". Sua declaração sugere que temas mais densos poderiam ser mal recebidos por pessoas com menos maturidade emocional, comprometendo, em certa medida, o desenvolvimento do projeto. Informou, ainda, que alguns alunos não conseguiram resolver no software gráfico, não concluíram, não imprimiram e começaram a reclamar: "[...] P'ra todo mundo: conversa. Não conseguimos fazer, por quê? Falta de vínculo, falta de compromisso, bloqueio com tema, bloqueio com o colega, bloqueio com o professor. E, aí, foi resolvendo e, agora, 'tá tudo bem". Este relato denota intenção do docente em procurar desvendar o motivo de o projeto não ter se encaminhado da maneira esperada, colocando, ao mesmo tempo, o aluno no papel de protagonista de seu aprendizado, a fim de fazer os ajustes necessários.

\footnotetext{
12 Síndrome de Burnout é um distúrbio psíquico de caráter depressivo, precedido de esgotamento físico e mental intenso, definido por Herbert J. Freudenberger como "[...] um estado de esgotamento físico e mental cuja causa está intimamente ligada à vida profissional”.
} 


\subsection{4 \\ Grau de motivação verbalizado por alunos e ex-alunos em relação às atividades pedagógicas}

Os dados analisados na categoria temática apresentada nesta seção foram separados em subseções correspondentes às duas principais redes de escolas técnicas cobertas pela pesquisa: a Etec-SP e o Senac-SP. Por sua vez, dentro de cada grupo, as respostas foram divididas em experiências pedagógicas percebidas: como mais especialmente positivas ou como menos especialmente positivas.

\subsubsection{1}

\section{Grau de motivação verbalizado por alunos e ex-alunos de escolas da rede Etec em relação às atividades pedagógicas}

Quanto ao grau de motivação verbalizado pelos alunos em relação às atividades pedagógicas, apesar de surpresa inicial de alguns com o volume de atividades relacionadas às artes plásticas, parte significativa dos alunos mencionou interesse em desenhar e ilustrar. O Respondente 14, por ser desenhista, comentou gostar bastante da parte de ilustrar, sobretudo à mão. De modo diverso, a Respondente 8 informou preferir ilustração no modo digital. Nesse sentido, o Respondente 9 declarou: "Rascunho a ideia, escaneio e faço o tratamento no computador". Também o Respondente 11 mencionou preferir começar no papel: "Eu gosto mais de ilustrar com lápis e, aí, eu passo p'r'o digital e faço a coloração no Photoshop". Já o Respondente 10 citou ter adquirido o hábito de desenhar e ilustrar com frequência, enquanto o Respondente 12 mencionou haver descoberto esta inclinação no decorrer do curso. Estas declarações sugerem que haveria certa tendência por parte de alunos que procuram o curso técnico de comunicação visual das escolas da rede Etec em considerar particularmente prazeroso o ato de desenhar e ilustrar, uma vez que isso estaria ajudando a desenvolver habilidades ligadas à criatividade e percepção, habilidades estas percebidas como relevantes para desenvolvimento de projetos de design. 
Com respeito a afinidades dos discentes em relação a atividades, o Respondente 12 ressaltou seu gosto pelo ato de criar: "O processo de criação e de pensar o que combina, isso foi muito incrível p'ra mim". De modo similar, o Respondente 13, relatando seu próprio processo criativo, declarou: "Eu gosto da criação mesmo, de dar ideia. [...] Eu tenho uns ápices de criatividade". Quanto a isto, o Respondente 10 destacou como relevante o conhecimento de semiótica: "Gosto da idealização da semiótica, porque ela é uma parte bem ampla dentro de todos os tipos de arte". Entre as atividades então citadas, destacaram-se: criação de banners, cartazes e pinturas diversas (com guache e/ou aquarela). No que se refere a processos, o Respondente 14, descrevendo seu modo pessoal de organizar o espaço, declarou: "[...] eu gosto de pegar os elementos e distribuir na folha, p'ra ver como que vai ficar". Já o Respondente 11 informou preferir diagramar no programa InDesign, defendendo a importância da proficiência neste aplicativo para projeto de revistas.

Outro ponto em comum entre os alunos da Etec seria o prazer em aprender e a utilizar adequadamente os aplicativos gráficos exercitados na disciplina "Aplicativos Informatizados em Design Gráfico". Os Respondentes 8, 9 e 10 mencionaram sua preferência pelo programa Photoshop; o Respondente 11, pelo InDesign; ao passo que os Respondentes 12 e 13, pelo Illustrator. Ainda, em relação aos aplicativos, o Respondente 14 afirmou que o software "domina" porque, a partir do computador, consegue-se fazer muito mais coisa do que se fosse fazer tudo à mão, acrescentando: "[...] é uma ferramenta a mais, acho que isso não tira o mérito do profissional, porque o profissional não precisa ser necessariamente um operador de software. Ele tem que pensar antes da máquina". Possivelmente por ser mais velho que a maioria e já estar trabalhando, o Respondente 14 teria, ao que se deduz, ideia mais realista a respeito da função do computador, tal depoimento sugerindo percepção de que a máquina não seria o fim, mas um meio. 


\subsubsection{1 \\ Experiências pedagógicas percebidas como mais especialmente positivas por alunos e ex-alunos de escolas da rede Etec-SP}

Entre os trabalhos de que mais gostaram, seja ao executá-los, seja como resultado final, os alunos de escolas da rede Etec citaram os exercícios de construção de escala tonal e cromática com grafite e lápis de cor, retrato em aquarela, desenho cego, desenvolvimento de papelaria, banners, criação de cartaz para o Museu da Casa Brasileira, bem como o projeto de uma revista. Com relação a esse exercício, o Respondente 13 mencionou que teria ajudado a desenvolver um anúncio para a revista e que apreciaria muito a área de publicidade: "Eu nem sabia que eu tinha dom p'ra isso. [...] Uma entrevista também que eu fiz, pesquisa de campo, criei minha própria matéria, eu me diverti, tive muita independência". A Respondente 15 mencionou ter gostado bastante desse projeto, apesar do estresse em seu desenvolvimento: "[...] não sei se é proposital, te jogam, te dão matérias, como deveria ser uma revista. O tempo é curto. É impossível dar exatamente tudo que precisa. [...] Mas, se você olhar, eles deram a base, botaram a semente, você tem que correr atrás". De modo diverso, o Respondente 14 declarou que: "A revista foi bem interessante, porque foi um trabalho feito em grupo total. E, até na apresentação, a gente falou com propriedade do que era a revista, cada matéria, o que cada um fez, foi um trabalho que deu satisfação".

Estas declarações parecem indicar que o projeto de uma revista, talvez por ser de caráter interdisciplinar, seria um exercício percebido como marcante para parte significativa dos respondentes, uma vez que, além de toda a parte criativa e técnica que envolveria seu desenvolvimento, possibilitaria a realização de entrevistas, criação de anúncios e de matérias. Outro ponto destacado seria a percepção da importância de saber trabalhar em equipe, bem como da necessidade de se adequar ao tempo de execução, refletindo, em certa medida, a realidade do mercado de trabalho. 


\subsubsection{2 \\ Experiências pedagógicas percebidas como menos especialmente positivas por alunos e ex-alunos de escolas da rede Etec-SP}

Em relação a experiências pedagógicas percebidas como menos especialmente positivas relatadas por alunos das escolas da rede Etec-SP, a Respondente 8 mencionou os relatórios para a disciplina de LTT (Linguagem, Trabalho e Tecnologia). Segundo ela: "O professor direcionava p'ra nossa área, passava, por exemplo, um texto sobre publicidade p'ra gente fazer uma análise e um fichamento das informações mais importantes do texto" e, mesmo não apreciando, informou achar importante o conteúdo ministrado. Em discordância, estaria o depoimento do Respondente 9: "Eu acho que LTT parece meio fora". Estes relatos sugerem que haveria certa resistência por parte de alguns respondentes a conteúdos teóricos, sendo que nem todos perceberiam seu valor para uma formação mais ampla.

Ainda, com relação a trabalhos menos empolgantes, o Respondente 11 citou que poderia listar todos os de guache. De acordo com ele: "A gente treinou mais escalas de cores, fez formas tridimensionais com guache (cubos, esferas etc.), fez também pinturas chapadas". Quanto a tais atividades, o Respondente 10 mencionou haver ficado insatisfeito com seu desempenho, acrescentando considerar importante estes exercícios com tinta guache, já que: "[...] faz a gente ter um estudo melhor de cores". O Respondente 16, por sua vez, declarou não ter gostado da proposta do desenho de "perfis rebatidos", com grafite, acrescentando: "[...] Eu ficava com raiva porque eu não conseguia fazer". Estas declarações parecem indicar que abordagens mais manuais, empíricas não seriam bem recebidas por todos; além disso, a percepção de um desempenho não satisfatório em determinada atividade contribuiria para a não identificação com a mesma.

Por seu turno, o Respondente 13 informou não gostar de trabalhos que envolvam o aplicativo Dreamweaver. De acordo com ele, "[...] códigos, essas coisas, não entram na minha cabeça". Já a Respondente 15 citou não ter apreciado o exercício em grupo do primeiro dia do curso, cuja proposta seria a criação de uma história em quadrinhos, envolvendo a elaboração de texto e desenhos de personagens. Segundo ela: "[...] expuseram todo mundo, poderiam ter feito uma dinâmica melhor 
p'r'as pessoas se conhecerem de uma forma diferente". Este depoimento sugere que alunos sem anterior habilidade com desenho e/ou ilustração não demonstrariam afinidade com tal proposta.

A respeito de exercícios percebidos como menos especialmente positivos, o Respondente 14, aluno do terceiro semestre, expressou que: "Tudo que vem p'ra agregar conhecimento, eu nunca acho desnecessário, acho que vai sempre ser bem-vindo. Eu sou um eterno aluno. Gosto de estar sempre aprendendo", o que corrobora a declaração do Respondente 16, do primeiro semestre e um dos mais novos: "[...] no curso, cada coisa que você 'tá fazendo tem uma finalidade p'r'o seu futuro ou p'r'o seu desenvolvimento". Estas duas falas sugerem perfis de alunos motivados, com vontade de adquirir conhecimento, independentemente da proposta.

\subsubsection{2}

\section{Grau de motivação verbalizado por alunos e ex-alunos} de escolas da rede Senac-SP em relação às atividades pedagógicas

Em relação ao grau de motivação percebido pelos próprios alunos com as atividades pedagógicas, o Respondente 34, aluno, informou: "Eu gosto do software. De produzir. É o que eu mais gosto". Este relato sugere que abordagens teóricas, para alguns alunos, não seriam muito bem recebidas. Em contrapartida, o Respondente 33, também aluno, enfatizou a importância de se estruturar o projeto desde seu princípio, ao mencionar: "Gostei de trabalhar com grid, montar a estrutura visual. Antes, eu me adentrava um pouco no design, mas era muito solto, não tinha esse fundamento técnico". Isto parece indicar que esse respondente, antes desses conhecimentos, trabalhava de maneira essencialmente intuitiva. O próprio Respondente 33 acrescentou ratificar este seu processo de transformação em sua disciplina pessoal de projeto: "Hoje em dia fica tudo muito mais natural quando você começa a planejar o que você "tá fazendo". Esta afirmação sugere convicção de que ao se abordar $o$ ato de projeto de maneira consciente, planejada e sistêmica, em modo mental dedutivo, desde o início, ele resultaria mais produtivo. 
Já o Respondente 35 informou que prefere se aprofundar na proposta dos projetos sem temer possível retrabalho. Segundo ele, "A gente vai fazer um cartaz. Então, vamos fazer uma imersão de como é fazer um cartaz, de jeitos de fazer um cartaz. Realmente, fazer um errado e ver: não ficou bom. Para tudo, volta e faz do começo". Este depoimento pressupõe necessidade de um processo interior de efetivo envolvimento e valorização da abordagem mais direta, empírica e experimental, com base na crença de que o erro promoveria o aprendizado.

\subsubsection{1}

\section{Experiências pedagógicas percebidas como mais especialmente positivas por alunos e ex-alunos de escolas da rede Senac-SP}

Em relação às experiências pedagógicas percebidas como mais especialmente positivas, o Respondente 35, aluno, mencionou o projeto de cartas de baralho, destacando o valor de possuir referências da história da arte e saber ajustá-las a um projeto de design: "Eu achei bem legal os últimos trabalhos em relação à composição das cartas. Porque foi passado um projeto, um estilo artístico, aí você tinha que adequar a sua composição dentro daquele movimento". Dentre os movimentos, segundo o mesmo Respondente 35, estava o "funcional", o "expressionismo" e o "art noveau": "Nós escolhemos o 'funcional', por sorteio. Tinha a possibilidade de mudar. Mas como nós três do grupo não somos nada funcionais, queremos fazer tudo exagerado, gigantesco, acabamos decidindo testar, contra ao que a gente gosta de fazer". Este apontamento sugere predisposição dos integrantes do grupo em se desafiar, possibilitando novas experiências criativas e projetuais.

Já a Respondente 38, ex-aluna, mencionou que haveria apreciado o projeto gráfico de uma revista. Para ela, "A revista foi o projeto que mais marcou porque eu fiz em equipe, [...] o que deu mais trabalho, o que levou mais tempo. [...] A revista, a gente utilizou na prática e era algo que se repetia. E a gente, fazendo várias vezes, aquilo fica mais fácil p'ra gravar". Sua fala parece indicar que trabalhos percebidos como mais colaborativos teriam potencial de trazer singular satisfação para alguns alunos. Sugere, ainda, que projetos vistos como mais programados, com certa repetição de elementos gráficos - como a diagramação de páginas de uma revista 
(compreendendo, também, determinadas alterações de imagens e de números de colunas) - teriam sido percebidos, por essa respondente, como mais prazerosos, resultando mais eficientes para o aprendizado.

Apesar de declarar inicialmente não apreciar atividades que envolvam tipografia, o Respondente 33, também aluno, destacou, como relevante, a proposta de se criar uma imagem utilizando somente palavras: "[...] era criar uma imagem usando tipografia, usando letras, fontes. [...] um cartaz sobre algum tema, fazer um 'All Type'. [...] eu quebrei muito a cabeça, demorei muito p'ra fazer, mas foi um processo muito legal de construir". Uma possível explicação para tal entusiasmo seria o fato de que trabalhos criativos percebidos como especialmente desafiadores, quando concretizados, proporcionariam grande satisfação para quem os desenvolve.

De modo similar à declaração da Respondente 38, a Respondente 37, outra ex-aluna, também apontou, como especialmente significativo, o projeto de uma revista.

Segundo ela, "O que mais me identifiquei foi com editorial. E a gente fez a apresentação no estilo banca. A gente apresentou p'ra elas [professoras] e elas comentavam no final. Foi muito bom isso p'ra mim. Eu acho que trouxe maturidade p'ra sala". Esta fala revela que não apenas a criação de um projeto editorial fora percebido como importante, mas também sua apresentação e posterior análise em sala, favorecendo, ao que parece, o amadurecimento da turma.

Ainda, em relação trabalhos percebidos com relevantes, o Respondente 34, outro aluno, mencionou o exercício de um projeto de cartaz: "Teve o do 'burnout' que eu gostei bastante. Era p'ra criar cartaz. [...] Eu coloquei em relação ao trabalho. Todo mundo tem esse lado de estresse, patrão chato, de acumulação de trabalho e não conseguir fazer". Em relação a tal projeto, relatou que haveria se identificado com o tema: "[...] eu trabalho com pessoas, com público. Sou garçom. [...] Tem muito cliente que fica te cobrando. A maioria é chata. Quer na hora. Parece que não entende". Este relato sugere que, embora a temática não sendo das mais leves e parecendo estressante a jornada de trabalho desse respondente, haveria envolvimento, e mesmo prazer com a atividade. 


\subsubsection{2 \\ Experiências pedagógicas percebidas como menos especialmente positivas por alunos e ex-alunos de escolas da rede Senac-SP}

Quanto a experiências pedagógicas percebidas como menos especialmente positivas, o Respondente 35 , aluno, em discordância à declaração do Respondente 34, citou a proposta de cartaz com a temática "Burnout versus Qualidade de Vida". Segundo ele, "[...] o próprio nome enraizou. Deu um 'burnout' em todo mundo. [...] A 'Qualidade de vida', cada um deixou meio de lado p'ra fazer essa do 'burnout". Uma possível explicação para isso seria o fato de que temas percebidos como mais densos poderiam, em algumas turmas, não ser bem recebidos, dificultando o desenvolvimento do projeto; apesar disso, a maioria dos alunos escolheria começar pelo tema mais desafiador. Ainda, quanto a este trabalho, o mesmo Respondente 35 informou: "No meu cartaz, eu pensei como uma pessoa que 'tá passando por isso. Algo mais simples, que não desse tanto impacto visual na pessoa. Utilizei um fundo branco, intuitivo. [...] O preto, o branco e o vermelho. O básico da comunicação".

Este relato sugere entendimento de que o projeto em questão seria direcionado a um destinatário específico. Para tanto, ao se colocar na posição de quem eventualmente estaria vivenciando o problema, facilitaria determinar os elementos da composição.

Ainda, a respeito de trabalhos de que não apreciaram muito, o Respondente 34, aluno, informou que: "Foram poucos ainda que a gente criou. Não vou me recordar de qual eu não gostei". Com base em seu depoimento, parece que esse respondente não teria intenção de se posicionar, pois se haveria poucos trabalhos realizados até o dado momento, seria possível se lembrar de algum que não tivesse apreciado executar. De modo menos evasivo, o Respondente 33, também aluno, afirmou ter gostado de praticamente tudo o que fora proposto. "Não teve nada que eu não gostei de fazer. Talvez umas coisinhas no começo do curso que era trabalhar com tratamento de imagem, coisas mais básicas de software que eu já sabia, então, eu ficava um pouco distraído". Isto sugere que haveria certo desinteresse por parte de alunos a conteúdos não desafiadores, como, por exemplo, algo familiar. 


\subsection{5 \\ Percepções comparativas dos alunos sobre práticas de trabalhos individuais e em grupo}

Os dados analisados na categoria temática apresentada nesta seção foram separados em subseções correspondentes às duas principais redes de escolas técnicas cobertas pela pesquisa: a Etec-SP e o Senac-SP.

\subsubsection{1}

\section{Perspectivas de respondentes associados a escolas da rede Etec-SP}

Em relação a percepções comparativas dos alunos sobre práticas de trabalhos individuais e em grupo, a Respondente 15 declarou preferir trabalhar sozinha, por gostar de fazer e entregar com antecedência. O Respondente 16, relatando sua própria experiência, declarou ter dificuldade em trabalhar em equipe. Segundo ele, "Quando 'tô' em grupo, eu não consigo ter aquela sintonia com as pessoas. Eu tenho voz baixa, não consigo dar uma ideia boa, porque eu tenho vergonha ou eu não consigo passar da maneira correta". O Respondente 10 também informou que "agiria melhor como indivíduo", alegando dificuldade em dividir tarefas. Por outro lado, relatou que trabalhos em grupo seriam importantes para desinibir-se no mercado de trabalho, acrescentando: "A gente tem que se reconhecer como parte de um coletivo também". Similarmente, o Respondente 14 mencionou preferir trabalhos individuais, embora tivesse aprendido no Curso a importância do trabalho em equipe: "A gente tem esse individualismo, mas quando você tem duas cabeças ou mais pensando, acaba melhorando o resultado". Além disto, comentou que em um curso sempre teria um pessoal que "se encosta" no grupo. O que corrobora o depoimento da mesma Respondente 15: "Eu prefiro, nessas horas, carregar o grupo e fazer, porque eu 'tô' aprendendo, fazendo pesquisa, então, se eu puder e conseguir fazer, ótimo. No nosso grupo, só dois faziam e dois levavam. Não dá p'ra fazer todo mundo trabalhar".

Neste sentido, o Respondente 5, professor, apontou vantagens e desvantagens de se propor trabalhos em equipe. Segundo ele, "[...] o grupo é uma coisa que pode ser muito boa, mas também é muito comum que seja uma maneira de alguns, 
que não gostem de alguma coisa, não fazer". Esta visão pressupõe preocupação de que exercícios realizados em equipe poderiam contribuir para que alguns alunos não se desafiem em aprender algo que, supostamente, não gostem, não desenvolvendo, portanto, determinadas habilidades.

De modo contrário, a Respondente 8, outra aluna, informou ter preferência por trabalhos em grupo: "[...] eu acho que todo mundo consegue somar um pouco do outro e ter um feedback também. Eu fico um pouco perdida quando faço trabalho sozinha. [...] Acho importante p'ra gente ir construindo algo p'ra chegar em um resultado final melhor". Seguindo esse pensamento, o Respondente 12 esclareceu que em grupo seria melhor, já que, para ele, "Eu nunca acho que o que eu fiz 'tá muito bom antes de ouvir uma pessoa falar". Para o Respondente 13, a vantagem do grupo estaria na possibilidade de dividir tarefas, uma vez que se sentiria muito sobrecarregado em fazer tudo por conta própria, porém, com uma ressalva:

"[...] às vezes, trabalhar em grupo não é fácil, porque cada um pensa de uma forma”.

O Respondente 9 ponderou que isso dependeria do trabalho, indicando o projeto da revista como sendo favorável para ser executado em grupo: "Como é muita coisa p'ra fazer, cada um tem uma afinidade com algum tipo de coisa, cobrindo as falhas dos outros”. Já, para trabalhos individuais, o mesmo Respondente 9 citou ilustrações e edição de imagens, acrescentando: "Uma ideia na minha cabeça fica muito boa e na cabeça do outro não e, até chegar em um consenso, fica difícil”. De modo análogo, o Respondente 11 declarou ser muito relativo, considerando inviável um grupo com mais de quatro pessoas. Para ele, "[...] tem a chance de ficar muito desorganizado e ter mais discordância de ideias"; entretanto, completa: "[...] Trabalho em grupo é bom p'ra desenvolver os brainstorms e a relação social". Informou que na escola teria preferência por trabalhar sozinho, para poder melhor se organizar nas entregas.

Estes resultados, equilibrados quanto ao favoritismo por trabalhos individuais ou em grupo, parecem refletir, em certa medida, as características próprias de cada aluno. Conforme depoimentos, os alunos que apresentariam preferência por trabalhar individualmente parecem possuir personalidades mais introspectivas, apresentar certa dificuldade em expor suas ideias e serem mais comprometidos com as entregas de trabalhos. Mesmo os que declararam preferência por trabalharem sozinhos, 
considerariam importante o grupo para trocar ideias, dividir tarefas e prepararem-se para o convívio social - características de ambientes de trabalho profissional.

\subsubsection{2}

\section{Perspectivas de respondentes associados a escolas da rede Senac-SP}

Com respeito a percepções sobre práticas de trabalho individuais e em grupo, o Respondente 33, aluno, informou a mudança notada após início do curso: "[...] eu preferia fazer trabalhos individuais. Eu acho que, por conta da minha profissão. Eu sou fotógrafo. [...] Mas 'tá sendo muito interessante começar a pensar dinâmica em grupo. [...] quando se junta com outras pessoas, surgem muitas ideias". Uma possível explicação para o fato seria que o Curso incentivaria a integração de práticas profissionais por meio do convívio social. Quanto à possibilidade de estar contribuindo com a própria profissão, o mesmo Respondente 33 afirmou que iria além: “[...] não só p'ra questão profissional, mas p'ra questão como formação humana. [...] Tirar a questão de só você 'tá fazendo aquilo e absorver a ideia de outras pessoas e produzir com aquelas pessoas". Este trecho do seu depoimento sugere valorização do relacionamento entre pessoas, especialmente em área interdisciplinar como a do design, mas também em demais atividades que envolvam o convívio humano.

Assim como o Respondente 33, o Respondente 34, outro aluno, apresentaria certa afinidade por trabalhos individuais: "Às vezes, eu prefiro produzir sozinho, porque eu coloco minhas ideias que eu tenho em mente em prática. [...] No trabalho em grupo, sempre tem a opinião contrária. Você quer colocar isso aqui e a outra pessoa já não gosta". Esta visão pressupõe dificuldade de parte dos alunos em lidar com pontos de vistas diferentes dos seus no desenvolvimento de projetos. Ainda, o mesmo Respondente 33 apontou determinado trabalho em equipe percebido como bem-sucedido: "Mas o [projeto] das cartas foi em grupo. [...] Cada um teve sua ideia e a gente encaixou tudo, deu p'ra fazer no tempo certo e foi bom. Não teve opiniões contrárias, cada um fez sua parte. [...] Cada um dividiu as tarefas e deu tudo certo". Este depoimento sugere, novamente, que o sucesso do trabalho em grupo não se daria em função de trocas de ideias, mas por não haver apresentado divergência de pontos de vista. 
De modo contrário, o Respondente 35, também aluno, destacou o valor colaborativo de trabalhos em equipe no andamento de projetos: "Do grupo, eu acho legal essa troca de experiência. Você conseguir ter um palpite, dar um palpite, ainda mais na parte de comunicação, de design. Você não 'tá criando p'ra você. Você 'tá criando p'ra outro. Eu acho que isso facilita no processo". Isto pressupõe existência, ainda que muito elementar, de um usuário final do projeto; além disso, o intercâmbio de ideias e sugestões seria um facilitador no desenvolvimento do trabalho. Quanto a percepções sobre práticas de trabalho individual, o mesmo Respondente 35 afirmou apresentar certa dificuldade. Segundo ele: "[...] como eu quero fazer muita coisa, acabo que eu me perco na ideia. Demora mais do que 'num grupo que 'tá todo mundo com o tema na cabeça". Tal visão sugere que o trabalho individual, por não promover intercâmbio de opiniões e experiências, seria um limitador para esse respondente no processo criativo de projetos.

\subsection{6}

\section{Filosofias pedagógicas eventualmente fundamentadoras de práticas de ensino adotadas}

Os dados analisados na categoria temática apresentada nesta seção foram separados em subseções correspondentes às duas principais redes de escolas técnicas cobertas pela pesquisa: a Etec-SP e o Senac-SP.

A respeito da fundamentação teórica do ponto de vista da educação, não foram identificadas muitas referências significativas a respeito desta categoria, sobretudo nas escolas da rede Etec. 


\subsubsection{1}

\section{Perspectivas de respondentes associados a escolas da rede Etec-SP}

Quanto a filosofias pedagógicas eventualmente fundamentadoras de ensino adotadas, o Respondente 2, professor, relatando haver estudado comunicação visual na mesma escola, como citado na seção 4.2.1.1, mencionou: "Eu fiz CV aqui na escola, mas eu vi que era isso que eu queria, interagir com as pessoas p'ra que elas se descobrissem e não fossem os copistas da vida, mas que assumissem autonomia das suas ações, então é o que eu mais trabalho com eles". Este trecho de seu depoimento sugere referência a conceitos de Educação Popular e Pedagogia Crítica, pregados por Paulo Freire, na defesa da educação voltada para a autonomia e desenvolvimento humano: "O processo de conhecer faz parte da natureza mesma da educação de que a prática chamada, 'educação popular' não pode fazer exceção”. (FREIRE, 2002, p. 132). Neste sentido, parece que o respondente estaria procurando incentivar seus alunos a pensarem de maneira crítica e reflexiva em relação a seu aprendizado, a ser aplicado em projetos de trabalho e, também, em suas vidas.

\subsubsection{2}

\section{Perspectivas de respondentes associados a escolas da rede Senac-SP}

Em relação à possível influência de alguma filosofia ou teoria pedagógica, a Respondente 29, professora, como observado na seção 4.4.1.1.2, apontou a teoria construtivista: "[...] tem um conceito construtivista, o ensino não é: matéria, nota, acabou. É bem mais complexo. [...] Não é: sabe mexer no Photoshop, sim ou não. [...] Tem todo um conceito. [...] A gente procura trabalhar de uma forma mais ampla, uma forma mais construtivista". De modo análogo, o Respondente 31, outro professor, também destacou como relevante a presença da filosofia construtivista, ao declarar: "Não consigo imaginar design sem essa filosofia pedagógica". Estes depoimentos sugerem que a filosofia construtivista estaria relacionada à prática pedagógica no Senac-SP, sobretudo no sentido de defender o olhar para o aluno como um ser singular em todas as etapas de seu desenvolvimento. 
Já a Respondente 30, outra professora, informou que se identificaria com Paulo Freire, Vygotsky e Anísio Teixeira, fundador das escolas vocacionais da Bahia, na época da ditadura: "Além do Paulo [Freire] e do Vygotsky tem a questão do Piaget, por causa das fases, o respeito às fases da criança". De maneira semelhante, a Respondente 32, outra professora, também declarou receber grande influência do pensamento de Freire. Segundo ela, "Eu gosto muito do enfrentamento do Paulo Freire, da libertação do oprimido. É entender que a educação é libertadora mesmo, [...] não existe outra solução p'ra gente mudar". Sua afirmação sugere sensibilidade em perceber que o aluno seria o autor de seu próprio aprendizado por meio da práxis, unificando ação e reflexão, propósito maior do ensino técnico. Revela, ainda, certo grau de ideologização política dessa respondente, mesclado a conteúdos mais estritamente técnicos da profissão.

A mesma Respondente 32 relatou que o Senac-SP se basearia nos princípios de José Pacheco, da Escola da Ponte de Portugal, o aqui chamado "Projeto Pontes", declarando: "Eu acho que tem de misturar diversos repertórios, pessoas de diversas idades, mas como sociedade, o Brasil ainda não está preparado p'ra isso.

[...] [É] Questão de pensar em problemas muito maiores do que a desconstrução da estrutura". Sua fala sugere importância de se adequar métodos e práticas adotadas no país a características específicas da realidade brasileira, de modo que nem sempre a utilização de modelos desenvolvidos em outros cenários socioculturais seriam percebidos como adequados ao contexto nacional.

Em síntese, os dados comentados acima apontam o construtivismo como a escola pedagógica que embasaria a práxis dos cursos das unidades escolares da rede Senac. Derivam, ainda, a prática com base na construção filosófica de Paulo Freire, Vygotsky, Anísio Teixeira, Piaget, além de José Pacheco. 


\subsection{7}

\section{Percebido alinhamento entre conteúdos trabalhados e objetivos da formação, segundo visão de discentes}

Os dados analisados na categoria temática apresentada nesta seção foram separados em subseções correspondentes às duas principais redes de escolas técnicas cobertas pela pesquisa: a Etec-SP e o Senac-SP.

\subsubsection{1}

\section{Perspectivas de respondentes associados a escolas da rede Etec-SP}

A Respondente 8 declarou considerar o conteúdo do curso adequado: "A gente tem algumas matérias que dão direcionamento, por exemplo, marketing ajuda nas matérias mais gráficas, mais digitais, vai direcionar o olhar p'r'o nosso público. Uma complementa a outra". Quanto a quem seria este público, informou que dependeria do trabalho executado. Isto sugere ideia de que, para cada projeto, haveria um tipo específico de destinatário, não havendo menção a características mais universais dos usuários, nem a suas necessidades em si mesmas. De modo complementar, a Respondente 15, além de julgar apropriado o que estaria sendo oferecido, informou considerar que muitos conteúdos não haveriam sido abordados: "Eu consegui entender uma parte, acho que ainda há mais áreas que eu não conheça. O pouco que a gente aprendeu de base, eu imagino que tenha muito mais coisa". Sua declaração parece indicar compreensão da amplitude da área que estariam estudando. De modo diverso, quanto a afinidades com diferentes módulos do Curso, o Respondente 12, aluno, comentou achar a parte manual do primeiro módulo antiquada: "As aulas manuais, há uns 5 anos atrás, talvez fossem mais importantes. Ninguém mais faz isso". Este relato sugere que abordagens mais manuais, empíricas, não seriam percebidas como relevantes na profissão do design gráfico.

Segundo o Respondente 16, o estudo teórico nas aulas de história da arte [Influência dos Movimentos Artísticos na Comunicação Visual] estaria sendo bastante pertinente: "O professor fala muita coisa relacionada à área, a relação dos signos, do significado, do significante". Nesse sentido, o Respondente 10 também informou ter aprendido 
nesta disciplina a exercitação da semiótica, acrescentando: "No geral, tudo que o curso propõe eu aprendi, como o uso das tintas, as técnicas, cada um dos aplicativos". Já, o Respondente 11 informou sentir falta de mais aulas teóricas de processos gráficos [Meios de Impressão e Processos Gráficos]. De modo contrário, o Respondente 13 declarou que seria dada bastante teoria, sentindo falta da parte mais prática. Quanto à quantidade de conteúdos abordados em um mesmo módulo, possivelmente por estar finalizando o TCC, o próprio Respondente 13 argumentou: "[...] as aulas de web design que a gente 'tá vendo agora no terceiro [módulo], a gente deveria ter tido antes, porque HTML não é fácil. [...] Agora, a gente tem que fazer um site, um monte de coisa, 'tá muito em cima". Sua fala sugere possível adequação de conteúdos.

O Respondente 14 declarou que, para um curso técnico, agregaria muitas coisas boas. Para ele, "Tem as disciplinas, os trabalhos, a gente faz, corre atrás e resolve". Completou achar importante uma periódica revisão curricular, alegando: "O público muda, principalmente em instituições particulares, então, você não pode pensar da mesma forma. Daqui há dez anos, seu público é outro. O mercado vai mudar e, p'ra se ter sucesso, você tem que acompanhar". Isto sugere que parte dos conteúdos de cursos técnicos de comunicação visual de escolas da rede Etec não estaria acompanhando as demandas da nova geração. Percebe-se, ainda, maturidade do Respondente 14 refletida em seu discurso.

\subsubsection{2}

\section{Perspectivas de respondentes associados a escolas da rede Senac-SP}

Em relação ao percebido alinhamento entre conteúdos trabalhados e objetivos da formação, o Respondente 33, aluno, acreditaria ser importante considerar o sujeito para quem o projeto é realizado. Para ele, "Eu acho o que eu mais 'tô' aprendendo é ver a comunicação sem ser pelo meu olhar. [...] Você aprende a criar pela perspectiva daquela pessoa, daquele público ou daquela região. Você descentraliza a informação de você". Este relato sugere atenção desse estudante quanto a compreender, desde o princípio, necessidades dos usuários dos projetos, embora, a rigor, tal termo não tenha sido empregado. 
De modo complementar, o Respondente 34, outro aluno, considerou importante haver adquirido conhecimento em harmonia das cores e em tipografia: "[...] antes, eu usava qualquer fonte que não combinava com as artes, agora já tenho um pouco de conhecimento. Era o que eu precisava. [...] Não adianta você só saber mexer no software e não ter conhecimento de nada". Esta fala parece indicar compreensão de que habilidades operacionais são necessárias, mas não suficientes. Além disto, para formação mais ampla, fundamentos teóricos específicos da área também seriam vistos como relevantes.

Para o Respondente 35, também aluno, a teoria ministrada no início do curso Ihe pareceu superficial, mas esta percepção teria mudado, ao mencionar que: "[...] o conteúdo fez sentido agora. [...] Primeiro, vou aprender história da arte. É algo de jovem? Vai 'numa Bauhaus, vai em algo mais diferente, mais descontraído. É algo mais clássico? Vai 'num art noveau, algo mais delicado. É a base de tudo". Seu depoimento revela entendimento da importância de se formar repertório prévio para auxiliar e justificar o processo criativo, além de isso também contribuir para formação mais ampla.

Por outra perspectiva, o mesmo Respondente 35 relatou que, no início do curso técnico, parte dos alunos estaria encontrando dificuldade em compreender o conteúdo passado: "[...] 'tava todo mundo dando uma desanimada, não 'tava indo muito bem. Não 'tava atendendo, mais por essa parte profissional, de achar que o conteúdo que 'tava sendo passado não ia ser útil na vida profissional". Ainda, de acordo com ele, o problema residiria no fato de haver, entre os alunos, poucas pessoas trabalhando em tempo integral, com pouca ou nenhuma afinidade com a área e elevada expectativa quanto a rápido ingresso no mercado de trabalho. Segundo o mesmo Respondente 35: "Eles [professores] fizeram uma adaptação: 'Software, esse tipo de coisa, que é mais detalhado, vamos dar uma maneirada, passar um pouco menos de conteúdo [prático] e passar a parte mais teórica, mais conceitual, agora'”. Este relato sugere atenção da instituição quanto a adaptar, dinamicamente, o conteúdo de acordo com o perfil da turma, além da valorização de certo equilíbrio entre teoria e prática. 


\subsection{8}

\section{Eficiência didática dos professores, segundo percepção de alunos e ex-alunos}

Os dados analisados na categoria temática apresentada nesta seção foram separados em subseções correspondentes às duas principais redes de escolas técnicas cobertas pela pesquisa: a Etec-SP e o Senac-SP.

\subsubsection{1}

\section{Perspectivas de respondentes associados a escolas da rede Etec-SP}

Em relação à eficiência didática dos professores, o Respondente 9, aluno, mencionou que parte dos docentes não encaminharia devidamente os trabalhos: “Eles [professores] podem direcionar, mas 'tê' uma abertura p'ra você fazer do jeito que quiser. Mas tem professor que extrapola na hora de dosar esta liberdade". Esta fala sugere que parcela dos professores não orientaria devidamente os exercícios, deixando, ao que parece, muito "solto". O Respondente 12, outro aluno, afirmou que nem todos os alunos apreciariam a assistência docente. Para ele, "Tem professores que gostam muito de intervir no seu projeto. Tem alguns alunos que aceitam, outros não, e isto gera debates". Este trecho do depoimento pressupõe haver direcionamento dos trabalhos por parcela dos docentes, somente não ficando claro se seria no sentido de impor uma ideia ou com o propósito de ensinar.

A esse respeito, a Respondente 27 , ex-aluna, relatando o projeto gráfico de jornal no $2^{\circ}$ ano, informou não ter recebido orientação. Para ela, "Não tinha um direcionamento do que você tinha que fazer. Não tinha atendimento da professora ir lá falar, por exemplo: essa diagramação não 'tá boa, você podia fazer de tal jeito, se você fizer desse jeito, chamaria mais atenção. Foi mais: fazem aí". Esta declaração sugere que, talvez, tivesse faltado instrução docente de princípios de diagramação e, também, atendimento mais individualizado. Pressupõe, ainda, que, mais do que incentivar o desenvolvimento de habilidades para diagramar, o intuito seria o de promover aprendizado de programas gráficos. Quanto a isto, a própria Respondente 27 comentou, incisivamente: "A orientação era péssima em quase todas as matérias que a gente tinha. Eu acho que a questão não era a formação dos professores, 
mas também não era a quantidade de alunos, porque tinha pouco. Eu acho que era mais desmotivação". Talvez a percebida falta de estímulo tenha relação com a remuneração dos professores de cursos técnicos.

Em compensação, a mesma Respondente 27, informando a orientação recebida no $3^{\circ}$ ano para o desenvolvimento do TCC, declarou que as coisas haviam melhorado. Segundo ela, "A gente tinha atendimento, as professoras eram mais atenciosas, cada turma tinha professora p'r'o TCC. [...] Todo o apoio das professoras foi bem interessante. Foi no TCC que eu aprendi a fazer várias coisas que eu não sabia fazer nos outros anos". Esta declaração parece indicar que a assistência docente recebida teria contribuído tanto para realização de TCCs adequados quanto para o aprendizado de habilidades, que, supostamente, já deveriam ter sido desenvolvidas.

De outro ponto de vista, o Respondente 12, aluno já citado, relatou perceber ausência de planejamento de algumas aulas. Segundo ele, "[...] parece que alguns [professores] não preparam o que vão ensinar, eles chegam e falam: 'Ah, é isto o que eu vou dar"'. O Respondente 11, outro aluno, também afirmou perceber deficiência de programação das aulas, sugerindo, como motivo, o estresse: "[...] algumas vezes, há uma falta de organização e, aí, os professores acabam confundindo data de entrega de trabalho, essas coisas". Com base em sua fala, parece que o fator não seria a negligência, mas a intensidade da jornada de trabalho docente. Já o Respondente 14, outro aluno, apontou para a percebida falta de motivação de parte dos professores. Para ele, "Alguns estão um pouco acomodados, não que sejam ruins, mas precisando se reciclar, se atualizar e voltar a ter prazer em dar aula". Uma possível explicação para esta afirmação, uma vez mais, talvez se relacione à remuneração dos professores.

Por sua vez, a Respondente 28, também ex-aluna, relatando as aulas de história da arte, informou ter se sentido um pouco perdida. Segundo ela, "Ela [professora] passava os slides, mas era muito desconexo na minha cabeça. Fora uma série de princípios básicos que você tem que passar p'ra quem não tem muita noção de como você tem que encarar uma obra". Seu depoimento pressupõe que nas aulas desta disciplina não seria apresentado um panorama geral dos movimentos artísticos e de seus artistas principais em ordem cronológica, 
que possibilitasse compreender mais facilmente seu contexto histórico, social, econômico e político.

De modo diverso, o Respondente 13, igualmente aluno, declarou que os docentes seriam ótimos: "Estão sempre aí p'ra ajudar, gosto de todos. Todos me enriqueceram muito". Complementarmente, a Respondente 8, aluna, perceberia grande empenho dos professores em auxiliar os estudantes. De acordo com ela, "Os professores são muito parceiros, ajudam a gente, tanto com relação a coisas daqui quanto de fora. Tem uma certa individualidade aqui em relação ao tratamento com os alunos". O Respondente 16, também aluno, destacou a percebida proximidade dos docentes: "São bons, principalmente a maneira como são abertos p'ra conversar. Eu sinto que não tem muito aquela barreira professor-aluno". De modo análogo, o Respondente 10, igualmente aluno, destacou a comunicação como ponto forte, pois, segundo ele: "Eles trabalham sempre com o diálogo, e isso é primordial p'ra mim". Esse mesmo Respondente 10 mencionou que apreciaria o método de ensino e a postura ética de cada um, afirmando: "Nunca vi falta de ética por parte de nenhum deles". Esta declaração pressupõe que os princípios éticos seriam parte integrante do ensino técnico em escolas da rede Etec-SP.

Para o Respondente 14, outro aluno, a maioria dos docentes seria capacitada: "Os professores são fantásticos, já me identifiquei com muitos. Eles têm uma bagagem boa e estão sempre acompanhando a juventude, sempre por dentro do que acontece e evoluindo, tanto como professor como pessoas". O que corrobora a visão da Respondente 15, também aluna, pois, segundo ela: "Eu tenho que tirar o chapéu p'ra muitos professores. Professor que demonstrar que tem interesse em ensinar, eu vou sugar o máximo dele. Todos me atenderam. [...] Eles te dão toda a base p'ra você correr atrás". Estes depoimentos sugerem que os docentes seriam percebidos como agentes de aprendizado.

De modo complementar, o Respondente 26, outro ex-aluno, comentando um exercício de composição, informou que a abordagem de determinada professora haveria sido muito eficiente. Para ele, "O que ela fazia era incrível. A gente cortava pedaços de revista, de texto e folhinhas coloridas, que eram as imagens. [...] ficava brincando com aquilo no papel, às vezes, por duas semanas, antes de definir uma página. 
Foi fundamental na minha formação". Isto sugere mérito dessa docente em proporcionar vivência de composição que, potencialmente, possibilitaria aos alunos desenvolvimento da percepção espacial, correspondendo aos exercícios de comunicação visual antes da inclusão do computador como ferramenta de ensino.

Os dados sistematizados acima sugerem que parte dos professores de cursos técnicos de comunicação visual de escolas da rede Etec-SP não estaria atendendo às demandas de parcela de alunos, sobretudo no planejamento de aulas e na organização de datas de entregas. Há quem tenha se identificado com professor que direciona o exercício/projeto; há quem tenha preferido professor que intervenha o mínimo, mas, no geral, destacaram, como relevante, a abertura para o diálogo, a postura ética ou, ainda, o método de ensino do docente. Apesar de ter sido apontada certa acomodação em alguns mestres, parte significativa dos alunos parece ter um grande apreço por eles, não apenas como modelos de profissionais capacitados a instruí-los de modo adequado e diligente, mas como humanos, atentos às necessidades dos discentes como indivíduos.

\subsubsection{2}

\section{Perspectivas de respondentes associados a escolas da rede Senac-SP}

Em se tratando da percebida eficiência didática dos professores, o Respondente 34, aluno, informou, primeiramente, que seriam três professores principais.

Quanto ao que ministraria "produção gráfica", mencionou ter gostado bastante de seu desempenho em sala de aula: "Ele é bem dinâmico, bem direto. [...] ele consegue passar com muita fluidez. [...] Era um conteúdo bem pesado, tipo de papel, processo de impressão e ele conseguiu passar p'ra gente com bastante facilidade". Esta percepção corresponderia à do Respondente 35, também aluno: “[...] em uma aula dele de produção gráfica, você vê que ele é articulado no que fala. Se você faz qualquer pergunta, ele sabe" e também corrobora o parecer do Respondente 33, igualmente aluno: "Ele é legal, explica bem. Você tem uma ideia bastante complexa com ele, você consegue produzir as coisas". Estas declarações parecem indicar que a abordagem didática utilizada por esse docente seria percebida como eficiente, transmitindo segurança e, por sua vez, facilitando o processo de instrução. 
Em relação à didática da professora responsável pela parte mais conceitual, o Respondente 34, aluno já citado, declarou considerá-la especialmente motivadora: "[...] é uma pessoa muito sensível. Apesar de ser bem brincalhona, ela consegue alcançar a gente, trazer essa questão da sensibilidade p'ra gente. Sempre superanimada, sensacional, maravilhosa". Esta mesma percepção quanto à abordagem utilizada por essa docente em sala foi descrita pelo Respondente 35 , também aluno: "Em relação a essas formas que ela acaba aplicando o conteúdo, [...] acaba dando uma descontração. Às vezes é um assunto sério, ela consegue mudar totalmente a história. [...] Você vê que ela tem propriedade no que 'tá falando", o que corrobora a visão do Respondente 33, outro aluno: "A gente "tá tendo mais aula com a professora que dá um pouco mais de teoria. Ela é bastante divertida, explica bem, gosto das aulas dela". Estes relatos sugerem que, apesar da relativa densidade dos conteúdos ministrados, essa professora apresentaria características pessoais e de dinâmica de aula reconhecidas como sendo prazerosas e eficientes, estimulando o lado mais emotivo e humano de seus alunos e contribuindo para adequado andamento da aula e do aprendizado.

A respeito da professora de aplicativos gráficos, o Respondente 33, aluno, relatou: "A outra é mais nova. E é bem legal ter contato com professor que é mais jovem porque traz uma perspectiva de uma pessoa que 'tá próxima da gente. [...] Apesar de [ela] ser jovem, não tira todo conhecimento que ela tem", o que complementaria a visão do Respondente 35: "A de 'Aplicativos' é essa parte mais cartesiana, algo métrico, exato. Por ser mais nova, essa parte da didática, ela acaba sofrendo mais pressão que os outros. [...] Mas quando tem algum problema, é a primeira pessoa que todo mundo corre". Isto parece indicar que professores mais novos tenderiam a apresentar mais desenvoltura em abordagens mais práticas, sobretudo relacionadas a conhecimentos de aplicativos. Sugere, ainda, que docentes jovens suscitariam maior identificação por parte de alunos, por conta desta proximidade de idade. Por outro lado, o menor tempo de prática pedagógica poderia gerar maior insegurança em relação a sua didática.

Estas declarações a respeito da eficiência didática dos professores parecem indicar, a princípio, que a equipe docente seria formada por professores com perfis bem distintos. Pela ordem descrita, o primeiro seria responsável pela parte mais ampla 
e mercadológica; a segunda, por questões mais conceituais e psicológicas e a terceira seria encarregada de abordagens mais práticas e técnicas dos aplicativos gráficos. Esta diferenciação de características pessoais dos docentes parece refletir, em certa medida, na esfera didático-metodológica e na assimilação de conteúdos.

Em se tratando da percebida eficiência didática de seus antigos professores de cursos técnicos de comunicação visual de outras unidades da rede Senac-SP, a Respondente 37, ex-aluna, informou, a princípio, ter muita afinidade com eles: [...] Teve só uma que eu não consegui criar uma empatia e acho que isso afetou um pouco até, da minha parte". Sua fala pressupõe que a inexistência de identificação com o docente poderia comprometer o interesse do aluno e, em certa medida, o próprio aprendizado. Ainda em relação à assistência aos alunos, a mesma Respondente 37 relatou ter recebido a atenção necessária. De acordo com ela, "[...] nos seminários, a professora era bastante transparente na devolutiva. [...] Eu sempre consegui sanar minhas dúvidas. Era ruim, porque a sala era muito cheia. A professora ficava de lá p'ra cá, ainda mais quando o atendimento era individual". Este fragmento de seu depoimento pressupõe que, apesar de um grande número de alunos em classe, os professores foram percebidos como atenciosos, seja dando um parecer sobre a atividade realizada, seja assistindo-os de maneira mais personalizada.

De maneira análoga, a Respondente 38, outra ex-aluna, comentando sua percepção a respeito dos professores de seu curso técnico, informou considerar parte significativa deles bastante presente: "[...] todos muito atenciosos com a gente, pacientes. Tenho boas lembranças dos professores. Eles se preocupavam com todo mundo. A maioria não era professor distante, coisa que eu percebo em alguns professores da graduação". Esta fala sugere valorização da proximidade docente na orientação das atividades educativas no ensino técnico. Contudo, a mesma Respondente 38 mencionou que nem todos seriam assim: "Teve uma professora que mostrava alguma coisa p'ra gente fazer, só que não ensinava como. [...] Ela tinha uma noção do que era bom e do que não era, só que a gente não sabia fazer, ela tinha que ensinar". Este relato parece indicar que esta professora, em especial, não demonstraria sensibilidade nem mesmo técnica de ensinar, não contribuindo, portanto, para um aprendizado eficiente. 
De modo complementar, como visto na seção 4.4.1.1.2, a Respondente 36, ex-aluna citada, informou ter recebido especial orientação em um trabalho no segundo módulo do curso. Segundo ela, "[...] no segundo foi identidade visual, a gente já teve que fazer um estudo maior de pesquisa p'ra fazer uma marca. Quando chegou na identidade visual, a professora explicou que não podia sair do nada a marca e que tinha que fugir do óbvio". Sua fala pressupõe atenção da docente em alertar para necessidade de pesquisa no início de um projeto gráfico. Parece indicar, ainda, preocupação em alinhar os conteúdos e as abordagens do estudo com demandas de trabalho profissional em módulos mais avançados.

Os dados apurados sugerem valorização de docentes que dominariam os conteúdos tratados, transmitindo seus ensinamentos com segurança. Pressupõem, ao mesmo tempo, profissionais sensíveis, atentos para identificar possíveis dificuldades individuais ou do grupo e flexíveis para atender tais necessidades.

\subsection{9}

Percebida eficiência pedagógica da formação

Os dados analisados na categoria temática apresentada nesta seção foram separados em subseções correspondentes às duas principais redes de escolas técnicas cobertas pela pesquisa: a Etec-SP e o Senac-SP.

\subsubsection{1}

\section{Perspectivas de respondentes associados a escolas da rede Etec-SP}

A Respondente 1, professora, citou que, apesar de cada um ter seu tempo, considera muito gratificante conseguir que entendam a área e adquiram todo o repertório. Em relação à evolução pessoal, a totalidade dos alunos revelou ter progredido bastante, posto que a maioria não teria contato com a área antes de ingressar, conforme relato do Respondente 12, um aluno: "Eu nem sabia ligar o Mac. [...] Aprendi como ouvir as pessoas e colocar na tela o que elas querem. Fazer elas falarem: “É isso mesmo o que eu quero!'”. Sua declaração sugere entendimento 
da importância de relacionar-se adequadamente no desenvolvimento de trabalhos em área transdisciplinar como a do design.

Por outro ponto de vista, o Respondente 13, também aluno, mesmo mencionando ter evoluído no Curso, não se sentiria preparado 100\%, em virtude de ainda não trabalhar profissionalmente. De modo muito similar, a Respondente 15, igualmente aluna, informou não se sentir preparada. De acordo com ela, "Aprendi muito, mas não o bastante. Eu sou muito exigente comigo. Eu ainda não vivi no mundo da comunicação visual, no trabalho, p'ra saber se o que eu sei é o bastante", o que corrobora o relato do Respondente 16, igualmente aluno, ao declarar não se sentir pronto. Para ele, "Eu ainda preciso me desenvolver mais no Curso p'ra conseguir, ao término, no futuro, melhorar". Estes depoimentos, muito semelhantes entre si, parecem indicar compreensão dos alunos de que o Curso estaria proporcionando conhecimento a respeito da área, mas que o campo da comunicação visual seria bastante amplo, necessitando de tempo de estudo e de prática.

De maneira diversa, o Respondente 9, outro aluno, declarou se considerar 100\% mais bem preparado e que aprendeu a importância de analisar o público a que se destinaria o projeto para, então, pensar em uma mensagem para atingi-lo de forma efetiva: "[...] não precisa ser técnica, às vezes pode ser só uma imagem, outras vezes pode ser uma palavrinha simples, uma gíria, vai atingir a pessoa". De modo complementar, a Respondente 8, também aluna, informou [com orgulho] ter adquirido bastante conhecimento na área, a ponto de conseguir estágio no Centro Paula Souza. Os demais citaram que se aprimoraram em técnicas de desenho e pintura, aprenderam técnicas de ilustração digital, diagramação, perspectiva, a usar aplicativos gráficos, além de se sentirem capacitados para criação de identidades visuais, banners, cartazes, flyers, revistas, anúncios, convites etc.

Por sua vez, o Respondente 11, aluno, informou se sentir mais capacitado em vários aspectos. Para ele, "Me deixou uma pessoa mais ativa, fez desenvolver minhas ideias mais rápido. Questão da criatividade mesmo, desenvolveu muito. Agora, procuro muito mais conceito nas coisas. Até na literatura me ajudou, 'tô' lendo muito mais". Relativo a esta percebida abrangência quanto à própria formação, o Respondente 10, outro aluno, declarou se sentir mais confiante. 
De acordo com ele, "Eu me sinto mais solto p'ra falar o que eu penso e acho que parei de temer o que eu ia fazer. Eu só paro p'ra pensar no resultado final depois que eu já executei. Aí, faço uma autocritica e vejo o que poderia melhorar". Ainda, com referência a seu progresso, a Respondente 15 mencionou perceber o mundo de outra maneira. Segundo ela, "Meu olhar já mudou. Depois do Curso, você começa a olhar as coisas diferente". Tal depoimento vai ao encontro da declaração do Respondente 2, professor, ao afirmar que, antes de ensinar design gráfico, seria necessário fazer uma alfabetização visual, que seria importante tanto para a atividade profissional quanto para a vida, acrescentando que o aprendizado dependeria da metodologia que se criaria para que os alunos se sentissem motivados para produzir algo com pertencimento.

Estes apontamentos revelam satisfação de grande parte dos alunos em relação ao seu progresso ao longo do curso e que as disciplinas oferecidas possibilitariam promover, por exemplo, conhecimento técnico de ferramentas e a sensibilização. Os dados sugerem que a percebida formação atingiria dimensões além das próprias expectativas, como ter adquirido gosto por leitura e autoconfiança no momento de projetar. Segundo depoimento de professores, o aprendizado aconteceria em função do envolvimento do aluno, seja por afinidade anterior à área ou por meio de determinado método de ensino que o estimule. No caso do Respondente 2, professor, possivelmente por conta de sua formação em artes plásticas, educar visualmente seria o primeiro passo.

Por seu turno, o Respondente 26, ex-aluno, mencionando a percebida eficiência pedagógica de sua formação, citou os trabalhos desenvolvidos no início da graduação em arquitetura. Para ele, "[...] todos os que envolviam produção de modelo tridimensional, eu me saí muito bem. Em 'Fundamentos do Projeto', todos os meus modelos eram muito bonitos. Eles eram limpos, não tinha marca de cola, os cortes estavam muito bem feitos sempre". Sua fala sugere que habilidades mais manuais, empíricas, teriam sido desenvolvidas no curso técnico. Completando esta visão, o mesmo Respondente 26 informou que seus trabalhos, na faculdade, seriam reconhecidos como adequados. Para ele: "Até hoje, eu tenho bastante cuidado em produzir o material. [...] Em 'Planejamento Urbano', a gente entrega material gráfico sempre (mapa, cartografia etc.). Os professores sempre falaram que as apresentações 
do meu grupo eram muito boas". Esta declaração lança luz no mérito dos cursos técnicos de comunicação visual em potencialmente promover o desenvolvimento de habilidades manuais.

Por outro ponto de vista, a Respondente 24, outra ex-aluna, mencionou sua anterior experiência de vida antes de sua admissão na faculdade. De acordo com ela, "O curso técnico me fez entrar [na faculdade] muito mais esperta p'r'as coisas do que as outras pessoas. Talvez, por eu já ter que pagar minhas contas, eu experimentei a faculdade de um jeito diferente, pelo menos do meu círculo de amigos". Note-se que essa respondente, na época de seu ingresso na faculdade, já arcava com as próprias despesas. Isto sugere que ela já trabalharia, possivelmente em função de competências e habilidades desenvolvidas em seu curso técnico.

Em se tratando de sua percebida eficiência pedagógica da formação, a mesma Respondente 24 declarou que algumas competências adquiridas no curso técnico teriam auxiliado seu desempenho na faculdade. Para ela, "A parte gráfica, eu acho que tive vantagem sim. A semiótica. O centro de proporção, agilidade também nos programas gráficos, isso sem dúvida. Porque eu já trabalhava também com isso. [...] Entregar o máximo nos projetos". Sua declaração parece indicar que determinadas competências de um designer gráfico haveriam sido desenvolvidas no ensino técnico de comunicação visual. Sugere, também, que essa respondente, em especial, seria uma pessoa atenta à própria formação profissional em design, ao se dedicar intensamente à atividade projetual desde a época do curso técnico.

A respeito a sua anterior destreza em aplicativos gráficos, a mesma Respondente 24 informou ter auxiliado no desenvolvimento de projetos na graduação. Segundo ela, quando chegou à faculdade, "[...] o que os outros estavam capengando, eu já 'tava pensando em outras partes do processo da criação. [...] eu não estaria aqui sem o curso técnico. A verdade é essa. Porque eu não teria emprego, eu não conseguiria pagar o cursinho". Esta afirmação pressupõe que ingressar na faculdade já tendo conhecimento da natureza operacional de programas gráficos possibilitou a essa respondente se ater a etapas criativas mais importantes. Revela, ainda, que o curso técnico teria propiciado sua admissão no mercado de trabalho, permitindo-Ihe financiar seus estudos preparatórios para posterior ingresso no ensino superior de design. 
Por sua vez, a Respondente 23, outra ex-aluna, comentando o início do curso de design na graduação, relatou já ter conhecimento de algumas coisas. Para ela, "[...] tudo o que eu tinha visto no técnico, eu voltei a ver [...]. Enquanto as pessoas 'tavam um pouco perdidas, sem saber exatamente o que fazer, eu já 'tava um pouco de saco cheio, porque eu tinha que fazer de novo uma coisa que eu já sabia fazer". Este relato parece indicar que parte significativa dos conteúdos apresentados e das atividades desenvolvidas no curso técnico seria similar aos do início do curso superior de design. Quanto à percebida eficiência em uma atividade específica, a mesma Respondente 23 comentou que: "Tem coisa do técnico que eu ainda uso, hoje em dia, por exemplo: encadernação de livro. A gente aprendeu alguma coisa de encadernação na faculdade, um ponto muito básico, só que eu aprendi muito mais no técnico". Sua fala sugere, novamente, que abordagens mais manuais, com características mais artesanais seriam bastante estimuladas no curso técnico de comunicação visual e, talvez, menos tratadas em faculdades de design.

De modo análogo, a Respondente 28, também ex-aluna, ao comentar exercícios de escala tonal, informou havê-los realizado tanto no curso técnico quanto na faculdade de design gráfico. Segundo ela, na graduação, "[...] teve TGA, a gente usou p'ra fazer teoria da cor. Pelo o que eu já tinha vivido lá atrás, eu sabia tudo o que eu não tinha que fazer. [...] Todos os atalhos, eu sabia como fazer melhor a escala. [...] Senti impacto do técnico em várias coisas". Este trecho pressupõe, uma vez mais, ênfase no curso técnico de comunicação visual em abordagens mais manuais, mais empíricas, relacionadas ao campo das artes plásticas. De modo complementar, a mesma Respondente 28 declarou perceber correspondência entre as temáticas dos dois cursos. Para ela, 'Tudo o que eu 'tô' vendo, p'ra mim, nada é novidade. [...] eu já tinha visto a grade, já sei quais vão ser os temas de cada semestre, mas eu sei que eles existem por causa do técnico e como vai ser mais ou menos cada um por causa do técnico". Sua fala pressupõe que as vivências de projeto no curso técnico teriam auxiliado os trabalhos na graduação em design gráfico.

A Respondente 25, outra ex-aluna, relatando sua percepção a respeito de certas disciplinas do ensino técnico, informou que algumas teriam contribuído, de fato, para seu melhor desempenho na graduação. Para ela, "[...] a [disciplina] de 'Aplicativos' foi superboa. As aulas de cor, [...] não sei se fez tanta diferença, [...] você 
acaba pegando. As de diagramação mesmo, composição, me ajudaram bastante a ter mais noção de diagramar e compor imagens e texto". Este trecho sugere que algumas aulas do curso técnico possibilitariam o desenvolvimento de determinadas competências, ao que se presume, importantes para aprofundamento na graduação e para atuação na área profissional do design gráfico.

Por seu turno, a Respondente 27, também ex-aluna, ao relatar uma habilidade desenvolvida no curso técnico, informou o adequado uso de aplicativos vetoriais. Segundo ela, "Eu sei mexer no Illustrator, mais por causa do TCC, porque eu tive que aprender meio que na raça. Isso me ajudou bastante, ter esse conhecimento do Illustrator p'ra fazer as pranchas de projetos. [...] Aprendi a ter um pouco de noção de diagramação". Sua fala sugere que essa respondente teria aprendido a utilizar o programa Illustrator não por haver tido uma boa experiência de aprendizado, mas por necessidade de executar o TCC. Pressupõe, também, que determinadas atividades do curso técnico teriam contribuído para desenvolvimento de habilidades para elaboração de esquemas, onde elementos, como textos, legendas, fotos, ilustrações, entre outros, seriam distribuídos.

Ainda, a mesma Respondente 27 informou, como relevante, ter algum conhecimento a respeito de cor, bem como haver desenvolvido certas destrezas manuais.

De acordo com ela, "Eu aprendi a ter uma noção básica de cor, do que chama mais atenção, do que chama menos atenção. [...] me ajudou a desenvolver habilidades manuais, como desenho, pintura. Aprendi a mexer com guache, com aquarela". Este depoimento sugere atenção em apresentar, aos alunos, um pouco de psicologia das cores. Pressupõe, ainda, que algumas abordagens do curso técnico de comunicação visual, como já relatado, seriam essencialmente manuais.

Os dados apurados sugerem que o aprendizado de determinados conteúdos e práticas do Curso Técnico em Comunicação Visual da Etec-SP - como, por exemplo, teoria da cor, semiótica, composição, diagramação, aplicativos gráficos seriam percebidos como importantes para a formação na área. Os dados também apontam para a ênfase do Curso em abordagens mais manuais, com características mais artesanais, sensoriais, empíricas, de "mão na massa", mais tipicamente da área das artes plásticas do que, propriamente, do design. 


\subsubsection{2}

\section{Perspectivas de respondentes associados a escolas da rede Senac-SP}

Em relação à percebida eficiência pedagógica da formação, o Respondente 34, aluno, aludiu a sua anterior ausência de contato com a área. De acordo com ele, "No começo, eu não tinha conhecimento de nada. Então, da história da arte até a tipografia, paleta de cores, harmonia, 'tô' aprendendo bastante coisa em relação a isso. Já foi um avanço p'ra mim. O conhecimento 'tá sendo bem legal aqui'. Esta declaração parece indicar que os fundamentos básicos do design gráfico estariam sendo abordados e considerados, por esse respondente, como sendo relevantes para ampla formação na área do design gráfico.

Por sua vez, a Respondente 36, ex-aluna, destacou como significativo, o aprendizado de aplicativos vetoriais: "[...] o que mais eu aprendi foi imagem vetorial, mexer com vetor. Ficou a lembrança do Illustrator, CorelDraw. Na graduação, não temos mais Corel, mas é até bom aprender o Corel, porque muitas gráficas usam. Foi pouco contato com o Photoshop". Este relato pressupõe que habilidades operacionais em aplicativos vetoriais seriam percebidas por essa respondente como especialmente relevantes para sua formação na área. Sugere, também, ausência de conteúdos mais relacionados a tratamento de imagens em seu curso técnico.

O declarado progresso de sua formação pelo Respondente 34 é compartilhado pelo também aluno Respondente 33. Para ele: 'Se eu preciso fazer um produto p'ra ' $x$ ' público p'ra 'y' proposta, eu consigo chegar com mais exatidão. [...] no software ou desenhando no papel, raciocínio, qualquer coisa p'ra conseguir chegar no que eu preciso fazer. Me sinto bem mais preciso". Esta fala sugere que, ao considerar o destinatário final do projeto, seja qual for a ferramenta utilizada, o desenvolvimento do mesmo pareceria mais fluente e o produto final mais acertado.

A Respondente 38, outra ex-aluna, informou que parte significativa do que estudou no curso técnico de comunicação visual seria aproveitado, dois anos depois, no ensino superior de design gráfico. Quanto à possível influência na execução de trabalhos na faculdade, destacou o aprendizado de aplicativos gráficos: "No geral, tudo um pouco, por causa do que eu aprendi a nível técnico, [...] principalmente no 
Photoshop, edição de imagens, recorte, colagem. [...] Se você imagina alguma coisa, você tem essa referência, você consegue executar". Novamente aqui, o conhecimento de ferramentas, sobretudo do aplicativo Photoshop, no caso dessa respondente, seria visto como relevante para ser aplicado na execução de qualquer projeto.

Diferentemente dos demais alunos, o Respondente 35, igualmente aluno, informou não se sentir, naquele determinado momento, plenamente capacitado para atuar na área. Segundo ele, "Eu preciso ter mais experiência. [...] É complicado o mercado de trabalho, porque tem muita gente boa. [...] Eu acho que eu 'tô' mais preparado do que quando eu entrei, obviamente, só que eu ainda sinto essa imaturidade". Esta sua percepção sugere entendimento de que a formação em design demandaria empenho e tempo para desenvolvimento de competências básicas, bem como noção da existência de grande concorrência na área em função da qualidade dos profissionais em atividade.

Por outro ponto de vista, a Respondente 37, também ex-aluna, mencionou sua percebida competência para execução de atividades na graduação. Segundo ela, "[...] eu já sabia editar fotos. Mas, o mais importante foi a percepção visual que eu já tinha. [...] a noção de quando uma coisa é adequada ao projeto e quando ela não é. [...] No começo, você quer colocar tudo e mais um pouco". Sua visão sugere ideia de que, quando não se possui muita experiência, a tendência seria incluir vários elementos em um mesmo trabalho. Pressupõe, também, valorização de se realizar projetos buscando determinada ordem entre elementos de uma composição.

A Respondente 38, ex-aluna citada, relatando seu próprio desempenho na execução de um projeto de revista na graduação, mencionou possuir prévio conhecimento. Para ela, "[...] eu já sabia que ia ficar muito pesado o arquivo. Eu já tomei cuidado p'ra salvar todas as imagens e todas as referências. Não precisei esperar o professor falar. [...] No momento que eu comecei a fazer, eu já comecei fazendo o certo". Esta declaração parece indicar que a anterior experiência no ensino técnico teria favorecido, em certa medida, para o desenvolvimento de competências importantes para uma vivência de projeto mais consciente e acertada na graduação. 
Com base nestes depoimentos parece que, de modo geral, os alunos apresentariam satisfação em relação à própria eficiência técnica da formação no decorrer do curso, seja em relação ao aprendizado de conteúdos coerentes com a área, seja em função da percebida evolução em habilidades operacionais. Já egressos de cursos técnicos de comunicação visual de escolas da rede Senac-SP apontariam, como relevante, possuir conhecimentos operacionais de aplicativos gráficos, tanto os vetoriais quanto os de manipulação de imagens. Outro ponto mencionado trata do desenvolvimento da percepção visual, percebida como importante para a execução de qualquer projeto. Por fim, os dados sugerem a compreensão de todos os respondentes de que questões como dedicação e tempo seriam necessárias para formação mais completa.

\subsubsection{0}

\section{Visão dos professores quanto ao curso técnico em que atuam}

Os dados analisados na categoria temática apresentada nesta seção foram separados em subseções correspondentes às duas principais redes de escolas técnicas cobertas pela pesquisa: a Etec-SP e o Senac-SP.

\subsubsection{1}

\section{Perspectivas de respondentes associados a escolas da rede Etec-SP}

A Respondente 1, professora, ao mencionar sua visão a respeito do ensino técnico de comunicação visual, relatou que notaria elevada evolução no desempenho dos alunos ao longo do curso. Para ela, "Os trabalhos executados no primeiro módulo, comparados com os do terceiro, percebe-se uma diferença bem grande". A própria Respondente 1 demonstrou satisfação com a atuação profissional de alguns ex-alunos: "E a gente tem vários que tão aí no mercado, porque o curso é também um leque muito amplo, ele oferece várias possibilidades, de fotografia a alguma coisa como ilustração hiper-real". De maneira bastante similar, a Respondente 3, igualmente professora, também mencionou a abrangência da formação: "[...] o nosso curso é um leque também. Acaba saindo alunos p'r'as artes plásticas, p'ra comunicação, até marketing". Estas declarações parecem indicar que os cursos 
técnicos de comunicação visual ofereceriam considerável diversidade de conteúdos e abordagens, possibilitando, a seus alunos, atuarem profissionalmente não apenas em design gráfico, mas em áreas próximas.

De modo complementar, o Respondente 6, outro professor, mencionou que o curso técnico ofereceria laboratórios, aplicativos gráficos a alunos, muitas vezes sem poder aquisitivo, mas com elevado potencial para estar ingressando e enriquecendo o mercado. Segundo ele, "[...] a importância é estar deixando claro como funciona o mercado, deles estarem engajados, alinhados com as novas tendências, mas também, de tornar acessível a pessoas, que, normalmente, não teriam outra maneira, sem o ensino técnico". O mesmo Respondente 6 acrescentou que o curso favoreceria bastante a formação, mas tudo dependeria do interesse e empenho do estudante: "Orientamos a manterem uma network, procurar eventos gráficos, de design, se apresentar, desenvolver um bom portfólio, blog, Facebook, Instagram".

Esta visão corrobora a do Respondente 4, outro professor, ao mencionar que o curso estaria contribuindo satisfatoriamente para a formação dos alunos. Para ele, "Eu não sei se a gente dá a base e, aí, ele vai p'ra faculdade com essa base, consegue interagir com o conteúdo de lá". [...] Chegou a ter instituição que copiou nosso Plano [de Curso] aqui [do Curso Técnico em Comunicação Visual]. Só mudou o nome da disciplina". Esta declaração sugere percepção desse respondente de que os conteúdos do curso técnico de comunicação visual seriam adequados à formação na área, a ponto de seu Plano de Curso ter sido utilizado em determinada faculdade de design gráfico. O mesmo Respondente 4, em relação ao nome do Curso, informou considerá-lo inadequado. De acordo com ele, "Você bota todo mundo que 'tá no eixo criativo e chama de comunicação visual. Não tem tanto design. Lembra muito mais um curso de propaganda". Esta fala parece indicar que o termo comunicação visual sugeriria qualquer manifestação visual, e não voltado a projetos gráficos, como seria normalmente aceito no campo.

Com base em depoimentos de professores, o Curso Técnico em Comunicação Visual da Etec-SP estaria contribuindo para adequada formação de seus alunos e atuação em diversificadas frentes de trabalho ao disponibilizar laboratórios de informática, aplicativos gráficos, conteúdos pertinentes, informações a respeito do mercado 
de trabalho, entre outros. Outra questão apontada como merecedora de atenção seria a percebida evolução discente no decorrer do Curso.

\subsubsection{2}

\section{Perspectivas de respondentes associados a escolas da rede Senac-SP}

A respeito do curso técnico em que atua, o Respondente 31, professor, declarou considerá-lo relevante. Para ele, "Vejo com muito bons olhos. É uma forma do aluno entender fundamentos do design, ingressar rapidamente no mercado de trabalho e ingressar na área, se for o caminho que ele quer realmente". Esta visão sugere mérito do curso em proporcionar a alunos conhecimentos importantes da área do design, permitindo ingresso no mercado de trabalho em tempo relativamente curto. Quanto aos conteúdos ministrados na época da implantação do curso na unidade, o mesmo Respondente 31 informou considerá-los inadequados. Para ele, "[...] no início do o curso, o conhecimento era muito mais administrativo do que voltado p'r'o design, a gente adaptava p'ra área. Falava com os administradores e adaptava". Este trecho do seu depoimento pressupõe que o curso haveria passado por um processo de ajustes no decorrer do tempo por conta, entre outros fatores, da atenção dos docentes à percebida falta de coerência de determinados conteúdos e propostas com a área do design.

Por outro viés, a Respondente 30, também professora, ao relacionar o curso técnico que lecionaria com outros ensinos, mencionou perceber equiparidade de conteúdo. Segundo ela, "[...] não fica atrás de nenhuma qualificação. Porque a gente 'tá falando de Bauhaus, de Pentagran, escolas p'r'o mundo todo". A própria Respondente 30 afirmou que, em certos casos, o desafio seria ainda maior. De acordo com ela, "[...] são três exercícios. Você conseguiu fazer um, você se qualificou. Se você conseguiu fazer dois, você se qualificou porque, se o cara já vem com um background, ele tem que ir p'ra frente, ele não pode retroagir". Seu relato sugere que o curso proporcionaria conteúdos relevantes para a formação discente, bem como diferenciação no grau de exigência em relação ao anterior repertório do aluno. A mesma Respondente 30 também destacaria o fator tempo na formação dos alunos. Para ela, "A identidade criativa é um tempo que dá p'ra se 
realizar. Mas é bem menos tempo que uma graduação, então, olha a responsabilidade que a gente tem que ter enquanto docente de, em menos tempo, manter uma qualidade de convivência no grupo". Sua visão sugere que, apesar de o tempo percebido como reduzido, seria possível o desenvolvimento criativo dos alunos e o convívio satisfatório da turma. Pressupõe, ainda, presença de conteúdos mais relacionados à área da publicidade e propaganda.

Já a Respondente 29, professora anteriormente citada, distinguiria, como importante, a práxis do ensino técnico. Para ela, "Eu acho o máximo o técnico porque é muita prática. Algumas faculdades é muita teoria, mas acho que, atualmente, 'tá mais equilibrado entre teoria e prática. Aqui, a gente dá teoria, mas joga logo na prática". Este depoimento sugere valorização a abordagens mais práticas no Curso Técnico em Comunicação Visual do Senac-SP, parecendo ainda mais significativo em área projetual como a do design. Pressupõe, ainda, entendimento de que o ensino superior, neste campo específico, não se restringiria a conteúdos teóricos.

De modo complementar, a Respondente 32, igualmente professora, a respeito dos cursos, afirmou tratarem-se de propostas distintas. De acordo com ela, "[...] perante uma graduação, são coisas diferentes, tudo é experiência na vida e, de certa forma, o [ensino] técnico te leva p'r'o mercado de trabalho em um espaço de tempo um pouco menor". Novamente aqui, percebe-se a questão do encurtamento do tempo como fator de distinção entre os cursos. A mesma Respondente 32 acrescentaria o valor da abordagem mais prática do curso técnico. Para ela, "[...] é muito relevante como modificação de vida, modificação de pensamento e, com a aceleração do tempo e tal, eu percebo que ele tem uma importância muito grande na nossa sociedade. Dessa prática, dessa experimentação". Sua fala parece indicar discernimento dos propósitos entre as formações e uma sensibilidade quanto ao mérito do ensino técnico que beneficiaria, além do indivíduo, todo o coletivo.

Em relação ao nome do curso, a Respondente 29 declarou considerá-lo inadequado. Segundo ela, "[...] é comunicação visual, mas na verdade é design, porque a gente não conseguiu colocar o nome design por conta do MEC. A gente chama de 'TCV' (Técnico em Comunicação Visual)" e, quanto a isso, declarou crer que comunicação visual seria percebida como algo não necessariamente relacionada ao design. 
Para ela, "[...] no mercado, comunicação visual, é aquela parte de colocar os banners, às vezes faz uma arte, mas não carrega todo o conceito do design, diagramação, é outro esquema". A mesma Respondente 29 mencionou a importância de informar os alunos: "A gente fala que é de design só p'ra eles não perderem o foco. Porque não é p'ra ajudar a instalar, não é sinalização".

Complementando tal visão, o Respondente 31 também mencionou, como problemática, a designação do Curso. Para ele, "[...] incomoda o título. Acaba que o mercado lê como design gráfico. O mercado vê de um jeito e o MEC vê de outro. Se é uma pessoa que não sabe o que é comunicação visual, não vem".

Estes depoimentos parecem indicar que, para alguém que estaria iniciando na área, como acontece, em geral, com quem procuraria o ensino técnico, a ausência de clareza quanto à denominação do curso poderia contribuir para sua desorientação, seja induzindo a uma escolha equivocada ou inibindo acesso de potenciais alunos.

Os dados comentados acima pressupõem atenção com a formação de indivíduos capacitados tecnicamente e sensíveis a questões sociais. Apontam, também, para a falta de clareza quanto à denominação do curso que contribuiria para desinformação a respeito da área. Os dados também sugerem ênfase do Curso Técnico em Comunicação Visual do Senac-SP em preparar seus alunos para o mercado de trabalho em tempo relativamente curto.

\subsubsection{1}

\section{Processos de avaliação de desempenho dos alunos}

Os dados analisados na categoria temática apresentada nesta seção foram separados em subseções correspondentes às duas principais redes de escolas técnicas cobertas pela pesquisa: a Etec-SP e o Senac-SP. 


\subsubsection{1}

\section{Perspectivas de respondentes associados a escolas da rede Etec-SP}

Quanto aos processos de avaliação de desempenho dos alunos, a Respondente 1, professora, declarou que, por ser uma área criativa, configuraria, a seu ver, a parte mais difícil. Segundo ela, "A grande estratégia de avaliação é nunca ter uma estratégia só, um instrumento só de avaliação, você tem que ter sempre dois, e quando você vai avaliar o prático, mostrar caminhos", pois os alunos possuiriam sensibilidade bastante aflorada, existindo o risco de destruir uma pessoa criativa caso não se percebesse tal potencial. Sua declaração parece indicar cuidado em promover o crescimento e desenvolvimento do aluno. A mesma Respondente 1 apontou a conveniência de uma avaliação intermediária que analisaria o desempenho individual, se cada um estaria acompanhando o curso, entre outros aspectos, não entrando em seu histórico escolar. Isto sugere preocupação em estimular o aluno a superar possíveis dificuldades durante o processo de aprendizagem.

Por outro ponto de vista, o Respondente 2, professor, declarou que avaliaria o aluno individualmente, por interesse, conhecendo cada um em uma relação de muito afeto, tentando entender um traço, um interesse específico para poder orientar e indicar, por exemplo, para alguma publicação. Segundo ele, "[...] quanto mais eu conheço eles, mais eu sei quem orientar e direcionar. [...]". Consideraria sua avaliação humanista, lamentando o fato de o Curso ser curto, sobretudo a modalidade de ensino "modular", e, às vezes, não propiciar um amadurecimento da maneira que se gostaria. Este depoimento sugere atenção e sensibilidade desse professor em relação às necessidades específicas de cada um. Além disto, parece indicar que o tempo do curso técnico não seria o ideal para pleno desenvolvimento discente.

Já para o Respondente 7, também professora, a base da avaliação seria o produto finalizado: se ele obteve bom resultado final em uma peça, significaria que soube usar as ferramentas de forma adequada. De modo semelhante à Respondente 1, acreditaria ser necessária a existência de mais de um instrumento de avaliação, propondo várias atividades. Segundo ela, procuraria avaliar no processo, indo de aluno em aluno, anotando cada etapa, bem como sua postura em sala. Isto sugere que, apesar de a respondente declarar como base para avaliação o produto 
finalizado, consideraria importante avaliar o processo. A própria Respondente 7 citou que se utilizaria da plataforma digital "Behance" para avaliar os trabalhos servindo, também, de portfólio virtual. Isto parece indicar atenção da respondente em buscar outros meios além dos tradicionais para a avaliação dos alunos, meios esses bastante valorizados pela nova geração.

Quanto aos critérios de avaliação, o Respondente 4, outro professor, informou que seriam vários: o aluno participar da aula, compreendendo ser proativo, ter postura de aula como cidadão, ser respeitoso com os outros, não atrapalhar o andamento da mesma, ser comprometido com horários (de chegada e saída), desenvolver e entregar as propostas no prazo e, no caso de trabalhos impressos, apresentá-los de forma adequada; além disso, utilizar as ferramentas de modo criativo: "Tem aluno que você ensina de uma forma e ele transcende e vai fazendo, vai utilizando aquilo como base". Seu relato sugere intenção de valorizar o aluno que busque seu próprio caminho para a execução dos trabalhos, atributo bem visto no mercado de trabalho. O próprio Respondente 4 relatou que o conceito "MB" [muito bom] seria pouco atribuído: "No Centro Paula Souza, avalia-se a curva de aprendizado: como ele entrou, o que ele aprendeu. Você tem a estética de produção desse trabalho, mas, eu não posso ter esse julgamento estético". A este respeito, percebe-se que a postura desse professor em relação ao aluno seria bastante humanista e que, nesta instituição, o resultado da avaliação não seria embasado na qualidade formal do produto final do trabalho, mas na evolução do desempenho do aluno.

Assim como o Respondente 4, que valorizaria trabalhos bem apresentados, o Respondente 6, já mencionado, informou que, no caso de trabalhos físicos, os critérios por ele adotados seriam a organização, limpeza e apresentação, incluindo uma possível proteção, como uma pasta ou envelope: "[...] independente de ser físico, se for um cartaz ou digital, se ele não está muito carregado, muito poluído, com excesso de informações". Esta afirmação sugere certo alinhamento entre o que o respondente valorizaria com os preceitos básicos do design gráfico. O mesmo Respondente 4 avaliaria a originalidade, procurando perceber apego a "lugares-comuns", observaria se o aluno pesquisaria, se desenvolveria as atividades no período da aula, se cumpriria prazos. Acrescentou, ainda, salientar o empenho de cada um. Para ele, "[...] tem alunos que têm dificuldade, mas correm 
atrás, são esforçados, isso também se leva em conta. Às vezes, tem aquele aluno que tem facilidade, mas é um pouco relapso". Nesses casos, comentaria: "Isso aí pode te atrapalhar no mercado". Isto parece indicar atenção do respondente em esclarecer que determinadas posturas não seriam bem vistas no "mundo real".

De modo complementar, a Respondente 3, outra professora, informou que, nas Etecs, seria dada preferência por avaliar aluno que trabalhe na Escola. Para ela, "[...] o meu vai trabalhar em sala, caso contrário, ele não aprende". Além disto, perceberia, entre os alunos, níveis variados de habilidades para desenhar e pintar: "Eu não posso ter uma avaliação comparativa de aluno que tem 'dom' p'ra desenho e pintura com o que não sabia nada. Mas aquele aluno que veio do zero e está crescendo, ele vai tirar uma nota boa também". Esta passagem parece indicar que a avaliação do professor seria evolutiva. Quanto à atribuição de conceitos, a mesma Respondente 3 declarou que: 'O aluno que tem 'dom', ele já é 'MB' [muito bom], ele já é ótimo aluno, já sabe, mas, se ele não trabalhar em sala, não vai ter esse prêmio. Ele vai ter que ter evolução". Novamente aqui, esta afirmação sugere valorização do aluno que se dedica à atividade proposta, independentemente de possuir anterior habilidade.

Como visto na seção 4.4.3.1, muitos dos alunos apreciariam levar trabalhos para serem executados em casa. Quanto a isto, o Respondente 5, igualmente professor, comentou: "Em termos de avaliação, de acompanhamento, seria muito mais próximo do ideal fazer em sala de aula. Geralmente, a atividade do dia, todo mundo faz e me manda no e-mail no final da aula ou, no máximo, da outra"; nesses casos, a avaliação seria dia a dia para a atividade enviada. Observe-se preferência desse professor em avaliar atividades executadas em classe. Isto sugere atenção do docente em dar assistência no desenvolvimento dos exercícios propostos, quando necessário.

De modo complementar, a Respondente 8, aluna, declarou perceber certa individualidade em relação ao tratamento dos alunos. Segundo ela, "[...] por ser um curso de criação, cada um vai ser avaliado de uma forma diferente, de acordo com as características da pessoa, o jeito que ela pensa, as referências anteriores que ela tem". Seu depoimento sugere ideia de que o conhecimento anterior de quem executa qualquer trabalho criativo seria projetado no processo criativo e que, ao avaliar o aluno, tais atribuições seriam levadas em conta pelo professor. 
Os dados apurados parecem indicar que, de modo geral, os docentes utilizariam mais de um instrumento de avaliação, se atentariam para a postura em sala de aula e teriam preferência por avaliar trabalhos executados em sala de aula. Além disto, o resultado da avaliação não seria embasado na qualidade formal do produto final do trabalho, mas na evolução do desempenho do aluno. Chama atenção o fato de que, dentre os critérios de avaliação, seriam consideradas as características, pensamentos e referências anteriores de cada um.

\subsubsection{2}

\section{Perspectivas de respondentes associados a escolas da rede Senac-SP}

Em relação a processos de avaliação, o Respondente 31, professor, declarou que tenderia a se basear em indicadores presentes no "Plano de Curso" (documento formal da instituição): "Eu avalio pelo o que é entregue. Tem os indicadores. Se o aluno atende, é aprovado. Caso não, tento fazer uma recuperação durante o processo mesmo. Nas aulas, estou vendo, em tempo real, se o aluno 'tá atendendo ao indicador". A Respondente 29, também professora, acrescentou que, a partir de

um feedback, o aluno teria oportunidade de se recuperar, de melhorar: "Se não deu certo de uma forma, a gente aplica outra estratégia. Por exemplo, não atendeu vendo uma palestra, a gente mostra um vídeo. Atividades diferentes também, [...] mas aplicando todos os conceitos técnicos". Estes relatos sugerem empenho dos docentes em acompanhar o desenvolvimento do aluno, identificar possíveis dificuldades e, por meio de abordagens diferentes, oferecer oportunidade de recuperação.

Ainda, segundo a mesma Respondente 29, no Senac-SP haveria um processo mais amplo de avaliação e não trabalhariam com notas. Segundo ela, "Para cada elemento da unidade curricular, faz-se uma avaliação parcial durante o curso ['atendido', 'parcialmente atendido' ou ‘não atendido'], feedback, recuperação e avaliação final, que é: 'desenvolvido' ou 'não desenvolvido'”. Quanto à formalização referente ao aproveitamento do aluno, afirmou que: "Depois que ele for desenvolvido em todas as unidades curriculares, aí ele recebe o certificado. [...] A gente explica que o certificado não quer dizer muita coisa. O importante é o portfólio". Isto sugere atenção do corpo docente em incentivar a produção cuidadosa, esclarecendo ao 
aluno que o mercado de trabalho do design priorizaria o que o indivíduo realmente sabe executar, mais do que um diploma.

De modo complementar, a Respondente 32, professora, apontou a importância de os alunos ponderarem a respeito de sua formação: "Eu tenho que demonstrar os meus métodos de avaliação e pergunto a eles. [...] Criaremos provas se o aluno quiser". Esta afirmação parece indicar disposição da instituição em deixar claro ao aluno seu protagonismo em relação a todo processo de aprendizado.

Quanto a ferramentas avaliativas, a mesma Respondente 32 informou: "Tem o 'CHA', Conhecimento, Habilidades e A titudes, que também é um método de avaliação. Aí, tem indicadores para isso: você observou que ele adquiriu conhecimento ' $X$ ' através do conhecimento da habilidade tal e ele tendo atitude tal". De acordo com essa mesma Respondente 32, a avaliação com base em indicadores seria muito subjetiva: "Tem muita linguagem da pedagogia que não se encaixa com a área da comunicação visual. [...] Nos indicadores não pode utilizar o verbo criar". Uma possível explicação seria que os indicadores seriam elaborados por pessoas sem muita afinidade com a área criativa, não apresentando, portanto, entendimento de que o verbo "criar" estaria intrinsicamente relacionado ao design.

Ainda, segundo o Respondente 32, haveria diferença de peso entre os itens que comporiam a avaliação: "Eu acredito que a avaliação seja 'projeto integrador' e falta. Todo o resto é menos que isso". Uma razão plausível para este ponto de vista seria o fato de que os conhecimentos, habilidades, atitudes e valores previstos para serem desenvolvidos e/ou aplicados nas atividades de cada UC de determinada QTP estariam materializados no "projeto integrador". Além disto, "falta" é um quesito de reprovação.

Já a Respondente 30, professora anteriormente citada, informou a existência de dois fatores do processo de avaliação: o quantitativo e o qualitativo. Para ela, "A questão quantitativa é voltada p'r'o gerenciamento de tempo, o quanto ele pode produzir. Eu pedi três peças. Por que, na qualidade, o número não foi atingido? O aluno não tem o software em casa. A gente começa a fazer o qualitativo". Relatou, ainda, que o aluno teria que escrever tudo: "O qualitativo 'tá pela justificativa. Essa mensagem 'tá querendo atender que necessidade? Qualidade visual. Tem que ter conceito, 
sempre. Conceito sustenta uma arte". Este depoimento sugere que, no processo avaliativo, os professores considerariam as dessemelhanças de produtividade entre alunos, buscando identificar os motivos de tal diferença. Além disso, valorizariam a reflexão e produção escrita, uma vez que o conceito fundamentaria a criação.

Os dados examinados acima apontam para um amplo processo de avalição, incluindo basear-se em indicadores presentes no Plano de Curso, atendimento personalizado em sala de aula, feedbacks constantes, mudança de abordagem, quando necessário. Destaque para a existência de dois fatores do processo de avaliação: o quantitativo e o qualitativo, que considerariam a diferença de produtividade entre alunos, bem como a valorização da análise e produção escrita.

\subsubsection{2}

\section{Percebidas necessidades de adequação de conteúdos segundo ex-alunos}

Os dados analisados na categoria temática apresentada nesta seção foram separados em subseções correspondentes às duas principais redes de escolas técnicas cobertas pela pesquisa: a Etec-SP e o Senac-SP.

\subsubsection{1}

\section{Perspectivas de respondentes associados a escolas da rede Etec-SP}

Quanto à percebida necessidade de adequação de conteúdo, a Respondente 25, ex-aluna, comentando a respeito das aulas de história da arte no curso técnico, declarou não haver amarração com a criação de, por exemplo, um produto gráfico. De acordo com ela, "[...] não tinha esta conexão do projeto com a história da arte. Faz muita diferença ter história do design no técnico. Até p'ra você ter mais noção do que que é o design em si. [...] Até p'ra você ter mais propriedade daquilo que você 'tá fazendo mesmo". Note-se que as aulas de história da arte no curso técnico estariam desvinculadas do propósito de se criar um novo produto. Isto sugere que a inclusão da disciplina de história do design na grade curricular e relacioná-la a atividades de projetos possibilitaria, aos alunos, uma visão mais abrangente da área. 
De modo complementar, a Respondente 23 , outra ex-aluna, relatando sua percepção a respeito do papel do ensino técnico, considerou pertinente maior abordagem de determinado conteúdo teórico. Segundo ela, "Eu sei que é um curso p'ra formar técnicos p'ra trabalhar no mercado de trabalho, de forma técnica, mas eu acho que falta um pouquinho mais de história. Mas, talvez, a carga horária foi muito de história da arte e pouco de história do design em si”. Sua fala parece indicar, assim como a da Respondente 25, necessidade de maior conteúdo de história do design. Em se tratando de conteúdos de natureza mais operacional, a mesma Respondente 23 informou ter ficado insatisfeita. Para ela, "As aulas de computador, digitais, ficaram a desejar. Faltou mais de UX [User Experience]. Não teve nada do técnico que eu aproveitei, de fazer site, p'ra computador, p'ra celular". Este relato apresenta uma visão crítica com respeito à qualidade pedagógica no desenvolvimento de sites.

De outro ponto de vista, o Respondente 26, outro ex-aluno, ao avaliar o Curso, considerou-o positivo, mas com pontos a melhorar, conforme citado na seção 4.4.1.1.1. Segundo ele, "[...] tinham muitas disciplinas que não estavam articuladas entre si. [...] A gente perdia nesse sentido, perdia tempo, porque tinha que fazer duas coisas diferentes com o mesmo objetivo que era, por exemplo, aprender o software no computador". Este depoimento pressupõe que a falta de integração entre as matérias estaria, algumas vezes, gerando retrabalho, comprometendo, em certa medida, o aprendizado.

Já a Respondente 27, ao comparar as aulas de serigrafia na graduação e no curso técnico, informou perceber grande diferença. De acordo com ela, no curso técnico, "[...] era mais teoria, porque não tinha como dar a prática. [...] Minha professora mostrou uns vídeos. [...] Eu não fazia a mínima ideia como a tinta passava por um lado e não passava por outro, sendo que era a mesma tela". Observe-se que a professora se restringiria a apresentar conteúdos teóricos e vídeos a respeito da técnica da serigrafia. Isto sugere que não haveria material ou mesmo estrutura física para aulas práticas que proporcionaria vivência dos processos de impressão.

A Respondente 23, ex-aluna já citada, comentando algumas aulas do curso superior em design, declarou encontrar, na faculdade, conteúdos importantes para sua formação em design que não teriam estado presentes em seu curso técnico. 
Para ela, "A gente tem que ler sobre a teoria do mercado. E não tem como falar de design sem falar do mercado. [...] A gente tem que falar de Marx, de liberais, de mercado, de teoria econômica. Não tem como desvincular produção de design". Note-se que essa respondente haveria sido apresentada a tais conteúdos na graduação e valorizado a relação do design com o mercado. Isto sugere que tais questões, talvez, não tenham sido abordadas no curso técnico de comunicação visual.

\subsubsection{2}

\section{Perspectivas de respondentes associados a escolas da rede Senac-SP}

Quanto a percebidas necessidades de adequação de conteúdos, a Respondente 36, ex-aluna, embora afirmasse ter sido um curso bom, declarou que determinados conteúdos teriam sido abordados de maneira superficial. Para ela, "Teve bastante coisa que eu poderia dizer que faltou ser aprofundado [...]. Acho que faltou mais coisas com Photoshop, mais sobre tratamento de imagem, [...] até mesmo diagramação. [...] Foi meio pobre”. Esta fala pressupõe necessidade de mais aulas de técnicas de manipulação de imagens, bem como de estruturação dos elementos gráficos no espaço específico de cada projeto. Ainda em relação à percebida carência de certos conteúdos, a mesma Respondente 36 citou os estudos da cor: "Uma coisa que eu acho que também faltou no técnico foi ensinar sobre psicologia da cor. [...] a gente estudou Gestalt bem por cima. Tem uma colega, que fez Etec, que tem muito forte isso. Eu vejo nos trabalhos dela, que ela pega muito fácil”. Este trecho do seu depoimento parece mostrar conveniência de ocupar-se mais intensamente em conteúdos da Gestalt em cursos de comunicação visual do Senac-SP. Parece indicar, ainda, que tais conteúdos seriam tratados mais aprofundadamente em cursos da mesma área em unidades das Etecs.

Já a Respondente 38, outra ex-aluna, relatando sua experiência no princípio do curso técnico de comunicação visual, mencionou considerar o trabalho proposto como inadequado. Segundo ela, "O primeiro módulo foi um pouco bagunçado p'ra mim. Não fez sentido muita coisa, tanto é que não ficou na minha memória. [...] O portfólio, no início, não tinha nem como. Não tinha objetivo, não tinha propósito nenhum". Esta passagem sugere que montar um portfólio, logo no começo do curso, 
quando habilidades ainda estariam sendo desenvolvidas, talvez não fosse a melhor proposta. Quanto aos demais módulos, a mesma Respondente 38 informou julgar os projetos apropriados: "No segundo, teve manual de identidade visual. [...] Eu senti, nos últimos, um impacto maior, porque tinha um propósito, tinha um projeto, tinha um porquê de fazer aquilo e a gente já tinha pegado um pouco de experiência dos primeiros". Esta declaração pressupõe que projetos com temas mais direcionados, com propostas mais claras, seriam percebidos como mais convenientes para seu desenvolvimento. Sugere, também, que experiências anteriores de projeto favoreceriam a realização de trabalhos subsequentes.

De maneira análoga, a Respondente 37, também ex-aluna, declarou não concordar com a ordem dos módulos. "[...] o primeiro de tudo tinha que ser identidade visual, porque tudo o que a gente cria tem uma identidade visual, até um portfólio. [...] Não necessariamente criar um manual de 'IV'. Mas essa noção de que as coisas têm que ter uma unidade". Sua fala sugere percepção de que, ao ser proposto um projeto de portfólio, conceitos provenientes da Gestalt, como "unidade", deveriam estar bem assimilados. Quanto aos demais módulos, a mesma Respondente 37 informou: "Em embalagem, a gente teve legislação, teve que fazer análise na gôndola. Tinha que fazer três PDVs [material de ponto de venda]. Eu achei adequado, porque foram os mesmos [conteúdos] que eu tive na graduação". Esta passagem sugere que conteúdos da publicidade e da propaganda fariam parte da grade curricular do curso técnico, sendo apreendidos como convenientes, uma vez que se assemelhariam aos conteúdos da faculdade de design gráfico.

\subsubsection{3}

\section{Processos de definição das temáticas das propostas dos exercícios de projeto}

Os dados analisados na categoria temática apresentada nesta seção foram separados em subseções correspondentes às duas principais redes de escolas técnicas cobertas pela pesquisa: a Etec-SP e o Senac-SP. 


\subsubsection{1}

\section{Perspectivas de respondentes associados a escolas da rede Etec-SP}

Quanto ao processo de definição das temáticas das propostas dos exercícios de projeto, a Respondente 1, professora, informou que ocorreria na semana de planejamento. Segundo ela: "[...] a gente decide temas das coisas e programa as nossas visitas técnicas. [...] A gente foi na exposição no CCBB ver o Paul Klee, porque, assim, são duas coisas: tanto 100 anos da Bauhaus e o nosso $3^{\circ}$, tarde e noite, o tema do TCC é o CCBB". Esta fala sugere atenção em escolher temáticas para o Trabalho de Conclusão do Curso que propiciem visitas técnicas enriquecedoras. Nesse caso específico, conseguiu-se unir duas temáticas: tanto a visita ao edifício do Centro Cultural Banco do Brasil, conhecer suas dependências e ter acesso a materiais gráficos - por exemplo, folhetos de exposições - como ver uma exposição relevante no âmbito do design, já que Paul Klee teria sido professor da Bauhaus.

A este respeito, a mesma Respondente 1 relatou que outro grupo de alunos também teria ido nessa mostra: "O $2^{\circ}$ [módulo] foi p'ra ver a exposição e pegar as fotos do Paul Klee, porque eles vão fazer a revista e uma matéria, é os 100 anos da Bauhaus". Este depoimento sugere que a escolha do tema teria sido bastante pertinente, propiciando visitas de alunos de dois módulos distintos, com propostas de trabalho também diferentes. Enquanto para alunos do $3^{\circ}$ módulo o CCBB seria um cliente que possibilitaria a execução de diversas peças, a exposição do Paul Klee forneceria conteúdo relevante para desenvolvimento do projeto de revista de alunos do $2^{\circ}$ módulo.

\subsubsection{2}

\section{Perspectivas de respondentes associados a escolas da rede Senac-SP}

A Respondente 29, professora, destacou a importância de haver afinidade do aluno com a temática do trabalho. Segundo ela, "As ideias de projeto partem do projeto integrador. Tem um tema geral e alguns subtemas que podem ser escolhidos por eles. A proposta é eles se identificarem com o projeto". Esta preocupação sugere que, havendo identificação do aluno com o tema do trabalho, o mesmo fluiria mais facilmente. De modo análogo, o Respondente 31, também professor, em relação 
ao protagonismo dos alunos no encaminhamento do projeto, relatou: "Direcionam de acordo com o objetivo final da 'Qualificação'. [...] Por exemplo: criar logo e manual de identidade visual. Decidem coletivamente qual ou o quê vão criar ou atender". Ainda, segundo ele, os projetos seriam desenvolvidos em grupo ou individualmente, conforme a turma e tamanho do projeto. Este relato sugere atenção em instigar os alunos a tomar decisões de projeto desde seu início. Pressupõe, ainda, que projetos mais complexos, que demandariam mais tempo, seriam executados em equipe.

De maneira complementar, a Respondente 30, outra professora, mencionou que as ideias de projeto viriam do tema gerador e que o Senac-SP orientaria duas propostas: "[...] uma é mostrar que você se desenvolveu quanto conhecimento de design. Mostrar um layout arrojado, [...] um trabalho simbólico ou uma ilustração bem definida. [...] Pegou todos os elementos de competência, trabalhou, cumpriu". Esta proposta sugere intenção de que o aluno se desenvolva tanto como indivíduo quanto como profissional da área. A mesma respondente acrescentou: "E tem um outro viés que é sempre o olhar para um design voltado p'r'o social. Que seria, por exemplo, cartazes alusivos p'ra que as pessoas tenham uma mensagem de melhorar sua qualidade de vida. [...] É o design voltado p'ra melhoria do mundo". Sua fala sugere presença de elementos claramente ideológicos, percebidos como até bastante positivos, nos exercícios pedagógicos apresentados aos alunos.

Os dados apurados a respeito do processo de definição das temáticas das propostas dos exercícios de projeto apontam para a percebida importância de os alunos se identificarem com a temática do projeto. Pressupõem, ainda, que, ao oferecer aos alunos sugestões de temas e possibilidade de escolha, o Senac-SP estaria incentivando a tomada de decisão de seus alunos, atribuição relevante para posterior atuação no mercado de trabalho. 


\subsubsection{4}

\section{Percebida relação de proporcionalidade entre teoria e prática em atividades pedagógicas}

Os dados analisados na categoria temática apresentada nesta seção foram separados em subseções correspondentes às duas principais redes de escolas técnicas cobertas pela pesquisa: a Etec-SP e o Senac-SP.

\subsubsection{1}

\section{Perspectivas de respondentes associados a escolas da rede Etec-SP}

Em relação à percebida relação de proporcionalidade entre teoria e prática em atividades pedagógicas, a Respondente 25, ex-aluna, informou que no curso técnico haveria pouca abordagem teórica. Para ela, "Tinha aula que era só teoria, como história da arte. A gente leu 'Design para quem não é designer' e 'O que é design?', só. De resto, era mais aula com alguma atividade pontual. [...] cerca de $20 \%$ de teoria e $80 \%$ de prática". Observe-se que haveria em seu curso técnico disciplinas somente teóricas: dois livros a respeito dos fundamentos do design haveriam sido indicados; o restante seriam atividades práticas. Isto sugere que a abordagem prática, segundo a percepção dessa respondente, seria quatro vezes maior que a teórica. O que corrobora a ideia de outra ex-aluna, a Respondente 23, pois, de acordo com ela: "No técnico era $20 \%$ de teoria e $80 \%$ era prática. Você realmente tinha que fazer as coisas". Suas falas sugerem ênfase em trabalhos práticos no curso técnico de comunicação visual de escolas da rede Etec-SP.

Em compensação, a mesma Respondente 23 acreditaria que o ensino técnico seria "técnico demais". Para ela, "Não tem como você ser um bom designer se você não aprende os fundamentos, as teorias. É legal você aprender a mexer na ferramenta, mas é mais legal ainda você aprender o porquê da ferramenta, ou, o que veio antes da ferramenta". De acordo com sua visão, a abordagem do ensino técnico seria basicamente prática e os conteúdos teóricos apresentados estariam sendo percebidos por essa respondente como insuficientes para a formação, não estimulando, ao que parece, o pensamento crítico dos alunos. 
Por outro lado, o Respondente 4, outro professor, optou por tornar sua disciplina mais prática, já que os alunos não consultavam o material teórico preparado por ele. "Eu projeto no datashow, vou fazendo e depois eles repetem do jeito que eu fiz ou eu dou um exercício que envolveu aquele conhecimento e ele vai fazer praticando. P'ra aplicativos funciona maravilhosamente". Sua afirmação sugere que, para alunos de design, com perfil bastante visual, expor o "passo a passo" talvez resulte mais eficiente do que a leitura de material teórico em linguagem verbal.

Já o Respondente 2, professor da disciplina "Influências dos Movimentos Artísticos na Comunicação Visual", ministrada em todos os três módulos, declarou que, apesar da natureza teórica de sua matéria, consideraria necessária a existência de, ao menos, uma atividade prática: "para o aluno se entender como produtor visual". Isto sugere que os alunos internalizariam melhor o conteúdo exposto teoricamente por meio de algum exercício prático.

De outro ponto de vista, a Respondente 27, outra ex-aluna, como mencionado na seção 4.3.2.1, relatando sua percepção quanto a aulas teóricas, mencionou que, algumas delas, deveriam ter abordagem mais prática. Para ela, "Não é uma aula que te prende. E, quando você tem 14, 15 anos, você quer fazer. Em MIPG (Meios de Impressão e Processos Gráficos) só teve teoria e eram umas aulas meio repetitivas, não tinha material, não tinha estrutura, como uma oficina". Esta passagem pressupõe que jovens teriam preferência por conteúdos mais práticos. Sugere, ainda, ausência de estrutura material e física - o que favoreceria uma disciplina com característica supostamente prática -, comprometendo, em certa medida, o aprendizado.

A mesma Respondente 27, comentando conteúdos teóricos em outras matérias, afirmou terem sido insuficientes. Segundo ela, "[...] a de processo manual, a teoria foi a professora falando 10 minutos como fazia um mockup e que era usado p'ra comercial de comida. [...] O quadro, a gente aprendeu na raça. Não tinha uma teoria de como usar as tintas, como usar os pincéis". Sua fala parece indicar falta de embasamento teórico em determinadas disciplinas antes do início de alguma atividade. Pressupõe, ainda, necessidade de maior aprofundamento em matérias com características mais práticas, bem como de maior equilíbrio entre abordagens práticas e teóricas. 
Já a Respondente 7, responsável pela disciplina "Aplicativos Informatizados em Design Gráfico", consideraria a mesma essencialmente prática, declarando necessidade de ajudar os alunos a criar, afirmando que, do contrário, ele poderia ir a qualquer escola de software. Relatou que: "[...] às vezes, o aluno sabe usar a ferramenta, mas não sabe desenvolver o projeto". Quanto a isto, a mesma Respondente 7 recomendaria bibliografia que fornecesse suporte teórico, configurando-se, a seu ver, em trabalho prático-teórico. Ainda, essa respondente acreditaria que a totalidade das disciplinas seria de formação; no entanto, para esta formação acontecer, seria necessário levar algo prático ao aluno. Os dados sugerem que alunos de cursos técnicos assimilariam melhor os conceitos por meio de atividades práticas, carecendo, porém, de algum embasamento teórico pertinente.

A Respondente 24, também ex-aluna, distinguiria a proporção de teoria e prática em trabalhos entre os desenvolvidos dentro e fora das classes. De acordo com ela: "No tempo para execução, no técnico, dentro da aula, $40 \%$ teórica e $60 \%$ prática. [...] todo o tempo extra era fazendo as peças, que não dava tempo de fazer lá. No técnico, $10 \%$ teórico e $90 \%$ prático. Não tinha muito relatório, leitura muito pouca". Sua declaração parece indicar que haveria certo equilíbrio entre conteúdos teóricos e práticos em sala de aula, porém as atividades realizadas fora de classe seriam basicamente práticas.

Assim como o Respondente 4, já citado, o Respondente 5, outro professor, declarou preferência por abordagens práticas: "A teoria, hoje, já é muito disponível nos meios digitais e ficar insistindo muito em aspetos teóricos, mais pesados, a grande maioria tem dificuldade com este tipo de abordagem". Para ele, em geral, os alunos prefeririam ver resultados, coisas mais palpáveis, com mais interação, mais manipulação de materiais, de software. O mesmo Respondente 5 relatou que a parte conceitual seria a mais desafiadora, em função de idades, tendências, cultura e experiências escolares anteriores, já que "[...] se lê muito menos, se escreve muito menos, há pouca preocupação com a língua formal" e, desse modo, "[...] você acaba tendo que traduzir muitas vezes aquilo em breves tópicos. Compartimentalizar o conhecimento em pequenos itens e tratar caso a caso, de uma maneira mais ou menos linear". Os dados sugerem que os alunos, talvez ainda mais particularmente em cursos técnicos, apresentariam, em certa medida, resistência a enfoques mais teóricos 
e que a prática, no curto prazo, talvez fosse mais eficiente em termos de aprendizado. Além disso, o perfil do aluno também influenciaria sua postura em relação às propostas e, consequentemente, em relação à abordagem utilizada pelo professor.

Os dados sistematizados parecem indicar ênfase em abordagens práticas no curso técnico de comunicação visual das unidades da rede Etec-SP. Se, por um lado, os alunos assimilariam melhor os conceitos por meio de atividades práticas, por outro, disciplinas presumidamente práticas seriam tratadas teoricamente, uma vez que não haveria estrutura física e material adequadas em algumas unidades escolares. Outra questão apontada seria a pouca fundamentação teórica em determinadas matérias, o que, de certa maneira, tenderia a influenciar negativamente a prática.

\subsubsection{2}

\section{Perspectivas de respondentes associados a escolas da rede Senac-SP}

O Respondente 31, professor, apontou o percebido destaque em aspectos práticos no ensino técnico, em relação a aspectos teóricos em atividades pedagógicas. Segundo ele: "No técnico é muito mais prático. A gente esmiúça a teoria conforme for aplicando na prática. A teoria é a base, a gente indica bibliografia". Seu relato parece indicar que os professores incentivariam seus alunos a se aprofundarem nos assuntos tratados, uma vez que a ênfase do Curso estaria em abordagens práticas. Complementando tal visão, a Respondente 29 , outra professora, também destacou o caráter prático do ensino técnico. De acordo com ela, "Eu acho o máximo o técnico porque é muita prática. [...]". A este respeito, atribuiu a etapa de criação como sendo o âmago dos projetos: "[...] acho que a criação é a parte mais importante, que é onde a gente põe a prática da teoria. Tem muita coisa que 'tá na teoria, mas que, durante o processo criativo, não dá muito certo. Seja por alteração financeira, seja por alteração do cliente". Uma possível razão para explicar esta afirmação seria o fato de que a teoria, algumas vezes, parece não prever erros e, em outras, não levar em conta fatores externos.

Ainda a respeito da percebida relação de proporcionalidade entre teoria e prática em atividades pedagógicas, a Respondente 36, ex-aluna, destacou os aspectos 
práticos. Segundo ela, "[...] eu diria que, no curso técnico, teve muito mais atividade prática em relação a quanto mexer nos programas de edição. Matéria teórica foi apenas em produção gráfica". O que corrobora a fala do Respondente 31, professor, como visto na seção 4.4.2.2: "Em produção gráfica é o momento em que a teoria é dada. Eu parto da malha, explico como é, a importância. Dou a teoria conforme o andamento do projeto". Este relato pressupõe cuidado em contextualizar os fundamentos na prática.

No ensino técnico, segundo a mesma Respondente 36, a parte teórica compreenderia cerca de $5 \%$ contra $95 \%$ de prática. Já a Respondente 37 , outra ex-aluna, perceberia no ensino técnico algo como $20 \%$ de teoria e $80 \%$ de prática. Similarmente, a Respondente 38, também ex-aluna, consideraria que a proporção seria de $25 \%$ de teoria e $75 \%$ de prática no ensino técnico. Estes depoimentos sugerem elevada ênfase em abordagens práticas no curso técnico de comunicação visual em atividades pedagógicas nas escolas da rede Senac-SP.

A Respondente 32, igualmente professora, como visto na seção 4.4.10.2, também destacou o valor da abordagem mais prática do curso técnico. Para ela, "[...] é muito relevante como modificação de vida, modificação de pensamento e, com a aceleração do tempo e tal, eu percebo que ele tem uma importância muito grande na nossa sociedade. Dessa prática, dessa experimentação". Sua declaração pressupõe valorização de abordagens práticas do ensino técnico na formação de profissionais, bem como de cidadãos atuantes.

Por outro lado, como visto na seção 4.1.3.2, o Respondentes 34, aluno, não imaginava que teria tantos conteúdos teóricos no início de seu curso técnico: "Eu achei que ia ser muito mais prático do que teórico. Mais prática do software. Aí, foi mais teoria do que na prática. [...] Ao longo do curso, fui entendendo do assunto, já foi mudando a minha opinião. [...] Eu não gosto muito de teoria, mas é bom". Complementando tal visão, o Respondente 35, outro aluno, informou ter se surpreendido: "Eu 'tava com uma coisa na cabeça que ia ser mais uma parte de criação, algo mais operacional e menos teórico. [...] Hoje, eu vejo que realmente fazia sentido, acabou que teve um significado. Quando você vê, já "tá praticando". Estes relatos sugerem que a base teórica inicial do programa estaria sendo 
percebida como importante, contribuindo para minimizar a visão negativa associada a componentes teóricos, além de apontar a prática mais concreta do projeto.

Complementarmente, outro aluno, o Respondente 35, como citado no item 4.4.7.2, informou que parte dos alunos apresentaria dificuldade em compreender o conteúdo ministrado no início do Curso: "[...] 'tava todo mundo dando uma desanimada, não 'tava indo muito bem. Não 'tava atendendo, mais por essa parte profissional, de achar que o conteúdo que "tava sendo passado não ia ser útil na vida profissional". Isto talvez se deva ao fato de haver, entre os alunos, poucas pessoas trabalhando em tempo integral, com pouca ou nenhuma afinidade com a área e elevada expectativa quanto ao rápido ingresso no mercado de trabalho. Segundo o mesmo Respondente 35: "Eles fizeram uma adaptação: "Software, esse tipo de coisa, que é mais detalhado, vamos dar uma maneirada, passar um pouco menos de conteúdo [prático] e passar a parte mais teórica, mais conceitual, agora". Seu relato sugere valorização de certo equilíbrio entre teoria e prática, bem como cuidado da instituição quanto a adaptar, dinamicamente, o conteúdo de acordo com o perfil da turma.

Os dados apurados acima parecem indicar ênfase maior em aspectos práticos em cursos técnicos de comunicação visual das escolas da rede Senac-SP, sobretudo no desenvolvimento de projetos em programas gráficos, com exceção de "Processos Gráficos", que apresentaria bastante fundamentação teórica. Por sua vez, alunos apontaram grande quantidade de conteúdos teóricos no início do Curso, parecendo indicar valorização e adição de componentes teóricos na última reestruturação.

\subsubsection{5}

\section{Materiais didáticos de apoio}

Os dados analisados na categoria temática apresentada nesta seção foram separados em subseções correspondentes às duas principais redes de escolas técnicas cobertas pela pesquisa: a Etec-SP e o Senac-SP. 


\subsubsection{1}

\section{Perspectivas de respondentes associados a escolas da rede Etec-SP}

O Respondente 4, professor, informou que, no início, perderia muito tempo preparando material para cada aula, que não era utilizado: "Eu fui vendo que isso não foi funcionado, aí, eu mudei. [...] Tenho os livros de apoio que eu passo, tem os sites, tem os tutoriais [sobretudo os da Adobe], mas eu deixei prática, porque eles não usavam [o material] na aula de aplicativos”. De modo análogo, o Respondente 5, outro professor, informou que passaria bastante material para os alunos: "[...] mas, o que eu percebo é que, talvez, uns $10 \%$ leem alguma coisa. O pessoal quer muito mais mão na massa. Eu tenho um monte de material, mando por obrigação, porque eu sei que, boa parte, guarda aquilo, nunca nem vê". Relatou, ainda, que, em termos de pesquisa, o que funcionaria melhor seria consultar vídeos no YouTube: "[...] agora, aqueles sites técnicos, cheios de textão, o cara bate naquilo e nem lê nada".

Similarmente, o Respondente 6, também professor, afirmou que usaria de tudo: "Eu recomendo livros, procuro dar acesso a PDFs de alguns livros, passo links de sites, uso bastante datashow, pego diversos exemplos, mostro vídeos" e, também, teria por hábito colocar na lousa um resumo ou itens mais importantes de determinado capítulo de livro ou site para servir de guia do trabalho a ser desenvolvido.

Estes depoimentos sugerem que, apesar da diversidade de material indicado pelos professores, de modo geral, os alunos não se debruçariam em questões mais teóricas, sobretudo com excesso de texto. Como referência, os tutoriais em vídeo parecem ser os mais adequados - supostamente pela anterior afinidade desta geração com os meios digitais. Outros recursos possíveis seriam a compartimentação de conteúdos e a demonstração do "passo a passo". 


\subsubsection{2}

\section{Perspectivas de respondentes associados a escolas da rede Senac-SP}

Quanto ao material de apoio, o Respondente 32 mencionou que o Senac-SP forneceria livros: "É um livro, inclusive, de professores do Senac: 'Produção Gráfica'. É bem legal o livro. Aí tem o 'Design Instrucional' que é de um outro autor, não me recordo o nome". De modo similar, a Respondente 29, também professora, explicou que: "A gente fornece três livros, sendo que um dos autores de um desses livros dá aula p'ra eles. É um livro de conceito, a teoria mesmo, que 'tá incluso no curso". Estes relatos sugerem atenção da instituição em proporcionar conteúdos teóricos que possibilitem contextuar a prática. Além disso, o fato de um dos autores também ser professor dos alunos seria um incentivo ainda maior à consulta.

Como já citado nas seções 4.3.1.2 e 4.4.3.2, a Respondente 30, também professora, informou que, na aula destinada à criação de logotipos, seria utilizado material diferenciado: "Essa aula eu boto prancheta, eles começam a criar. Eu vou trabalhar com massa de modelar. Eles vão modelar mesmo a tipografia e o símbolo".

De modo similar, a Respondente 29 , outra professora, também comentou a utilização de outros tipos de materiais para desenvolvimento de projetos: "A gente tem disponibilidade de mesas de desenho, lápis de cor. Eles não precisam trazer porque já tem aqui, faz parte do curso deles. A gente pega lápis de cor, canetinha, régua, todo o material". Estes relatos sugerem que, ao expor os alunos a abordagens e materiais menos convencionais, estariam proporcionando experiências enriquecedoras, estimulando habilidades sensoriais, motoras e cognitivas, bem como promovendo a socialização. 


\section{5 \\ Resultados concernentes ao subproblema 5 \\ (elementos de metodologia de projeto exercitados)}

\subsection{1}

\section{Estrutura metodológica básica de projeto exercitada com os alunos}

Os dados analisados na categoria temática apresentada nesta seção foram separados em subseções correspondentes às duas principais redes de escolas técnicas cobertas pela pesquisa: a Etec-SP e o Senac-SP.

\subsubsection{1}

\section{Perspectivas de respondentes associados a escolas da rede Etec-SP}

O Respondente 4, professor, informou que, sendo sua disciplina "Aplicativos Informatizados em Design Gráfico", seus alunos teriam que aprender ferramentas, tais como Photoshop, e, assim, não seria dada ênfase à concepção de projetos, mas à montagem de projetos ao computador. No entanto, segundo ele, não ficaria restrito apenas a isto, passando-se à seguinte metodologia criativa: "Pegar o briefing, ver quem é o seu cliente, o que quer, o que já fez, o que gosta. De tudo o que ele falou, transformar em imagem", recomendando-se, ainda, pesquisar na internet e utilizar o que se chama de "quadro semântico", em que se inserem informações pertinentes ao cliente em forma de imagem e texto: "Em cima desses dados, o aluno vai produzir imagens. Em cima dessas imagens, ele começa a montar o layout, mas sempre aberto à experimentação".

O mesmo Respondente 4 explicou que empregaria o método de Francesco Careri, chamado "Derivas" (correspondente ao "flaneur", de Walter Benjamim): "Você sai em uma determinada região da cidade e vai explorando. Eu tento fazer eles vivenciarem o projeto". Tal medida, segundo seu relato, enriqueceria o trabalho de seus alunos. Sua concepção de metodologia de projeto estaria, assim, menos atrelada a restrições técnicas de projeto, baseando-se, essencialmente, em exercícios mais livres e soltos, em correspondência com processos criativos mais característicos das artes plásticas. 
De maneira complementar, o Respondente 6, outro professor, como mencionado na seção 4.4.3.8, informou que seus alunos, após terem sido apresentados a logotipos considerados "bem-sucedidos" e "malsucedidos" e incentivados a desenvolver um logotipo ou marca com determinada intenção, iniciariam o processo criativo por tentativa e erro: "[...] vão ter que fazer diversas versões e nós, enquanto professores/orientadores, vamos vendo se estão indo por um caminho certo". Ainda, segundo o mesmo Respondente 6, os alunos poderiam quebrar regras, mas com consciência, sendo necessário, para tanto, conhecerem os fundamentos, bem como serem expostos a amplo repertório referencial de marcas já desenvolvidas para evitar plágio ou lugar-comum: "[...] vão fazer uma pesquisa e procurar valor em relação a marcas ou logotipos já existentes no mercado". Em geral, como comentou o próprio Respondente 6 , os alunos realizariam várias versões, sendo até mesmo orientados neste sentido: "No mercado de trabalho, você sempre apresenta mais de uma opção. E, a partir daí, você vai chegando ao que o cliente deseja. Não é saudável, comercialmente, ficar tão apegado a um conceito, a uma ideia". Isto sugere que, nesse processo, o professor faria o papel do cliente e os alunos vivenciariam algo mais próximo à realidade do mercado. Pressupõe, ainda, a importância conferida a circunstâncias práticas de mercado a pautar o processo de projeto dos trabalhos desenvolvidos em classe.

O mesmo Respondente 6 informou que haveria alunos que não conseguiriam interromper seus processos criativos ao final do projeto, sendo necessário informar-Ihes que: "Olha, o mercado lida com prazo, chega um momento em que vocês têm que determinar um conceito e desenvolver até o final". Seu depoimento sugere valorização de restrições práticas do mercado incidindo sobre a prática de projeto dos alunos, em especial quanto à noção de responsabilidade no cumprimento do cronograma acertado com seus clientes.

Quando inquiridos a respeito da estrutura metodológica básica de projeto exercitada com os alunos, os respondentes desta pesquisa, invariavelmente, não tinham elementos a relatar. Por exemplo, a Respondente 25 , uma ex-aluna, informou não haver sido exposta a elementos de metodologia de projeto em seu curso técnico, sendo apresentada, somente no curso de graduação, à estrutura metodológica clássica de projeto em design, por diferentes professores em diversas disciplinas. 
Para ela, na graduação, "[...] focam bastante em metodologia de projeto, que é uma coisa que eu não tive no técnico. Por semestre, cada professor fala do projeto em si, a metodologia que a gente vai seguir". Observe-se, de acordo com essa respondente, que a valorização do aparato metodológico característico do campo do design apenas ocorreria no âmbito do nível superior, não alcançando o estágio dos cursos técnicos, isto é, sem a disposição disciplinada preliminar aos alunos das diferentes fases de projeto e da forma com que elas se articulam sequencialmente. Diante disto, parece existir uma lacuna com respeito à metodologia de projeto no âmbito do curso técnico.

Os dados apurados sugerem relevância de contexto de trabalho norteando o desenvolvimento de projetos em sala de aula. Além disto, o método de projeto em design pressuporia, em determinados casos, uma abordagem indutiva, mais espontânea e menos comprometida com uma disciplina de projeto do geral para o particular, como tende a ser ensinada em cursos superiores de design. A ausência de uma exposição mais sistemática de metodologia de projeto no âmbito dos cursos técnicos talvez se explique pela escassez de professores especificamente formados em design atuando na área ${ }^{13}$.

\subsubsection{2}

\section{Perspectivas de respondentes associados a escolas da rede Senac-SP}

Com respeito à maneira como se iniciaria um projeto, a Respondente 29, professora, informou: "A gente procura trabalhar primeiro no papel, porque se consegue desenvolver melhor a ideia, pensar melhor. [...] Depois escaneia, passa p'r'o computador p'ra vetorizar, melhorar, reajustar, colocar no grid". Seu depoimento parece indicar entendimento de que $o$ ato de rascunhar com $o$ instrumento diretamente no suporte seria potencialmente mais fecundo nas fases iniciais da geração de alternativas. Sugere, também, centralidade do ato de desenhar na concepção ensinada do método de projeto em design, não levando

\footnotetext{
${ }^{13}$ Informações informais obtidas pela pesquisadora sugerem que as escolas com um quadro de professores com formação mais específica em design teriam mais propensão a apresentar elementos de metodologia de projeto em design a seus alunos no ensino técnico.
} 
em consideração etapas de conceituação do problema, levantamento e análise de dados, determinar requisitos de projeto, entre outros estágios do processo de projeto. A linguagem deste tipo de desenho tenderia a ser mais figurativa. Além disto, a estrutura metodológica básica de projeto exercitada com os alunos seria, essencialmente, indutiva, em modo mental mais associado às artes plásticas.

De modo análogo, o Respondente 31, também professor, quanto ao desenvolvimento de projetos exemplificou: "Eu pedi a identidade visual da empresa, a missão, visão, valores, posicionamento, personalidade e, a partir disso, eles deveriam rascunhar no papel 50 logos. Um logo de cada grupo foi definido e, aí sim, vetorizam no software". Sua fala pressupõe cuidado ao expor previamente os alunos às características do logotipo a ser criado e sugerir um número considerável de alternativas para, somente então, em processo de ideias, definir o partido final a ser finalizado no computador.

De maneira complementar, a Respondente 37, ex-aluna, relatando determinada atividade proposta em seu curso técnico, informou que essa mesma serviria como base para desenvolvimento de uma identidade visual própria. Segundo ela, “[...] a gente teve que fazer um trabalho prévio que era uma análise da identidade visual de uma marca que já existia. Então, a gente analisou a marca, os pilares, as características, mas não tinha essa base do que é a metodologia”. Assim, apesar da atenção em se propor a análise precedente de uma identidade visual, parece não haver sido exposto o método clássico de projeto. Ainda, a mesma Respondente 37 observou que: "No técnico, quando você não sabe ainda muito, você não pensa no todo. Você pensa numa embalagem que você quer, ah, 'lindona', só que você não pensa no que que você vai ter que fazer p'ra quando chegar naquilo". Sua declaração sugere ênfase em aspectos estéticos do produto final, mais característico de um certo formalismo das artes plásticas, parecendo se esquivar de questões mais diretamente relacionadas à funcionalidade dos projetos, o que estaria mais de acordo com o método clássico de projeto em design.

Ainda, relativamente ao desenvolvimento de projetos, a Respondente 32, outra professora, defendeu a imprescindibilidade de algum grau de pesquisa prévia, observando que: "Os alunos começam fazendo pesquisa para ampliação de repertório. A maior fonte acho que é internet hoje em dia. [...] Eles vêm muito crus". 
Seu ponto de vista denota eventual ausência de estímulo à aquisição de conhecimento em séries escolares precedentes, falta de tempo ou, ainda, desinteresse em assuntos relativos à área, bem como possível ênfase em exploração preliminar das situações de projeto. Além disso, a internet parece ser o meio mais utilizado em pesquisas no ensino técnico, possivelmente por aliar tempo curto e facilidade de acesso. Procurando diminuir tal deficiência, a mesma Respondente 32 informou que: "A gente vai fazendo 'Design Thinking', fazendo[-os] pensar com a óptica de outras pessoas, vai expondo as ideias em plenário, vai mostrando cases que funcionaram, que não funcionaram com aquela ideia". Seu depoimento pressupõe intenção em direcionar os alunos para a área do design, expondo-os a referências e contribuindo para inspirar futuros projetos.

Complementando esta visão, a Respondente 29, professora já citada, enfatizou interesse em incorporar técnicas e procedimentos metodológicos variados: "Brainstorming, construção de mapa conceitual, enfim, todas essas formas a gente aplica aqui, o que vai melhor se adaptando, dependendo da turma, do assunto". tal relato sugere propósito de apresentar aos alunos uma variedade de conteúdos, técnicas e ferramentas, procurando estimular sua criatividade, em diferentes âmbitos e maneiras, no desenvolvimento de atividades de projeto.

Como visto, os dados analisados parecem indicar a atenção em expor os alunos a diversificados conteúdos e procedimentos metodológicos para a geração de ideias. Convém ressaltar a centralidade do ato de desenhar em processos de geração de alternativas, desconsiderando-se as demais etapas do método clássico de projeto. 


\subsection{2}

\section{Centralidade eventualmente conferida aos usuários dos projetos}

Os dados analisados na categoria temática apresentada nesta seção foram separados em subseções correspondentes às duas principais redes de escolas técnicas cobertas pela pesquisa: a Etec-SP e o Senac-SP.

\subsubsection{1}

\section{Perspectivas de respondentes associados a escolas da rede Etec-SP}

De acordo com a Respondente 1, professora, para desenvolvimento de projetos, os alunos partiriam, em geral, de um cliente existente, utilizando-se de sua história como base para chegar a um produto novo, a uma marca nova a ser introduzida no mercado. A mesma Respondente 1 mencionou que, após a formação das equipes, o tema de projeto, sendo escolhido, daria início ao desenvolvimento do briefing e demais etapas do planejamento: "[...] desde o conceito do nome, o logo, até a criação de embalagem, slogan, campanha publicitária, storyboard, comercial de televisão e apresenta-se isso". Assim, conforme a própria Respondente 1 afirmou, o propósito seria, também, o de treinar os alunos para o TCC (Trabalho de Conclusão de Curso): "Ele [aluno] apresenta, conceitua, justifica e defende a sua ideia". Observe-se que o projeto partiria de um cliente e da história de sua empresa ou instituição, sugerindo intenção de introjetar nos alunos a importância de se conhecer sobre quem se projeta e sobre suas circunstâncias. Parece, entretanto, que o usuário final do projeto não seria, exatamente, levado em conta, não parecendo haver compreensão mais completa e investigativa de suas necessidades e dos contextos de uso do trabalho em projeto, entre outros aspectos também menos aprofundadamente, ao que se presume, considerados.

A Respondente 8, uma aluna, como citado na seção 4.4.7.1, a respeito do conteúdo do curso, ressaltou a figura do público: "A gente tem algumas matérias que dão direcionamento, por exemplo, marketing ajuda nas matérias mais gráficas, mais digitais, vai direcionar o olhar p'r'o nosso público. [...]". Quanto a quem seria este público, informou que dependeria muito do trabalho a ser desempenhado. 
Sua fala sugere ideia de que para cada projeto haveria um público específico, não havendo referência a um universo de usuários. Isto corrobora a visão do Respondente 14, outro aluno, como visto no item 4.1.4.1, ao afirmar que: "Comunicação visual é um pouco de marketing também, tem que vender o produto da pessoa. P'ra isso, a gente tem que atingir o público dele". Aspecto também comentado na seção 4.1.5.1, o Respondente 9, igualmente aluno, afirmou que o importante seria analisar o público. Para ele, "Você analisa e pensa uma mensagem efetiva p'ra aquilo. Não precisa ser técnica, às vezes, pode ser só uma imagem ou uma palavrinha simples, uma gíria, vai atingir a pessoa".

Em complemento, a Respondente 27, uma ex-aluna, em referência a aulas de marketing, como citado na seção 4.4.3.1.9, considerou estarem relacionadas à questão publicitária. Segundo ela, "[...] era p'ra aprender a produzir peças gráficas voltadas p'r'o lado publicitário, como atingir um público, como saber qual é seu público, como traçar esse perfil e como fazer peças direcionadas p'ra esse perfil específico que você "tá trabalhando". Observe-se que o termo "público" teria sido usado com frequência pela respondente. Para ela, também, a atividade de projeto teria, como base, prévia identificação de determinado público.

De modo bastante semelhante, a Respondente 24, também ex-aluna, comentando a abordagem que considerou predominante em seu curso técnico, informou que os exercícios eram mais "populares", tais como, folders, sites. Além disso, haveria, de fato, uma aproximação maior com o repertório conceitual e metodológico da publicidade. De acordo com sua visão, a atividade de projeto: "[...] tangencia a propaganda, vai vir um briefing. Tem que entender por que aquele briefing é daquele jeito, quem é seu público. Fala-se em cliente e seu público, usuário não. [...] No técnico, tinha essa pegada mais publicitária, era muito mais mercado". Sua fala coincide com as declarações das Respondente 8 e 27, pressupondo ideia de se projetar para um público particular, e não, propriamente, para um universo de usuários, denotando menor familiaridade com a especificidade metodológica do design e maior aproximação com o método criativo da propaganda.

Observa-se, assim, que grande parte das propostas e abordagens apresentadas aos alunos em cursos técnicos de design gráfico parecem ter centralidade 
e anterioridade do ato de desenhar, com preocupações estetizantes, em processos indutivos de concepção, o que estaria mais consoante a modos criativos das artes plásticas, de certa forma, desconsiderando-se a cultura específica de projeto em design. Tais lacunas metodológicas e conceituais relativamente acentuadas na formação do ensino técnico, talvez seja consequência de recrutamento de parcela de professores sem formação específica em design.

\subsubsection{2}

\section{Perspectivas de respondentes associados a escolas da rede Senac-SP}

Relativo a possíveis processos de projeto, a Respondente 30, uma professora, destacou a importância de formar repertório criativo. Segundo ela, "A parte digital teria que abandonar, um pouco, e ir p'r'o papel, p'r'o chão, p'r'o grafite, p'ra parede. Começar pensando no primitivismo, processo clássico, ordem, depois, neste momento das trevas, tudo trazendo p'ra soluções que vão atender às mídias de hoje". Este trecho de seu depoimento sugere, além do já observado propósito de proporcionar aos alunos vivências criativas com base em movimentos artísticos e técnicas diversas, que a ideia seria o meio de produção (manual, impressa ou digital), não havendo referência a se projetar para um universo de usuários.

Tal aspecto, também, comentado na seção 4.4.7.2, trata da importância de se considerar o sujeito para quem o projeto é realizado. De acordo com o Respondente 33, um aluno, "Eu acho o que eu mais 'tô' aprendendo é ver a comunicação sem ser pelo meu olhar. [...] Você aprende a criar pela perspectiva daquela pessoa, daquele público ou daquela região. Você descentraliza a informação de você". Seu relato sugere atenção desse estudante quanto a compreender, desde o princípio, necessidades dos usuários dos projetos, embora este termo não haja sido, a rigor, empregado. Ainda, como visto na seção 4.4.9.2, o mesmo Respondente 33 mencionou a relação entre produto, público e proposta. Para ele, "Se eu preciso fazer um produto p'ra 'x' público p'ra 'y' proposta, eu consigo chegar com mais exatidão. [...] no software ou desenhando no papel, raciocínio, qualquer coisa p'ra conseguir chegar no que eu preciso fazer. Me sinto bem mais preciso". Este trecho do seu depoimento parece indicar que, 
ao considerar o destinatário final do projeto, seja qual for a ferramenta utilizada, o desenvolvimento do mesmo pareceria mais fluente e o produto final mais acertado, pressupondo, mesmo que incipiente, ideia de usuário.

De modo similar, como citado no item 4.4.3.2, o Respondente 34, outro aluno, mencionando o manual de identidade visual que estaria sendo realizado, informou a grande quantidade de etapas. De acordo com ele, "A gente pesquisou e tinha que produzir uma identidade visual p'ra uma empresa. Falar o conceito da marca, o público-alvo, a tipografia que é p'ra ser usada e o que não usar na identidade. [...] É bem complexo". Novamente aqui, entre outros aspectos, parece haver preocupação em determinar o "público-alvo" do trabalho. Em tal contexto, parece que o termo faria referência ao destinatário final do projeto, sugerindo se referir a um público específico, não correspondente, exatamente, às atribuições de usuário.

Os dados sistematizados parecem indicar a atenção em se identificar o público específico ao qual se destinaria o projeto, mas não há referência a usuário universal de projetos. Este aspecto sugere maior aproximação de abordagens mais especialmente relacionadas à área da propaganda do que, propriamente, à do design.

Chama atenção o fato de que, após tantas entrevistas, um volume relativamente exíguo de dados tenha emergido sobre questões do método de projeto ensinado, parecendo informar que tal método não teria centralidade na atual pedagogia dos cursos técnicos de comunicação visual. 


\section{6}

\section{Resultados concernentes ao subproblema 6}

(linguagens visuais de trabalhos de alunos)

Com base em observações e acompanhamento de aulas e em apresentações de projetos de alunos, foram notadas determinadas características na linguagem visual dos trabalhos produzidos. De modo geral, tais padrões sugerem caráter formal, plástico, semântico e simbólico mais ingênuo, com traços referenciais oriundos da linguagem de desenho animado, ilustração, história em quadrinhos. Percebe-se, em grande parte dos trabalhos apresentados pelos alunos, ausência de domínio da linguagem própria do design, que implica elementos como modulação, linhas regulares e controladas, ausência de elementos arbitrários e caprichosos, simplificação, síntese, unidade formal, geometrização, entre outros aspectos, como indicou Vignelli (2009, p. 11) em seu Cânone:14 "[...] Isto significa necessidade de se projetar algo que tenha sentido, que não seja arbitrário, que tenha uma razão de ser, alguma coisa em que cada detalhe carregue o sentido ou possua um propósito exato, voltado para um alvo preciso". ${ }^{15}$ (tradução da pesquisadora)

\footnotetext{
${ }^{14}$ (VIGNELLI, M. The Vignelli canon. 2009)

15 "It means to design something that has a meaning, that is not arbitrary, that has a reason for being, something in which every detail carries the meaning or has a precise purpose aimed at a precise target" (Ibdem, p. 11).
} 

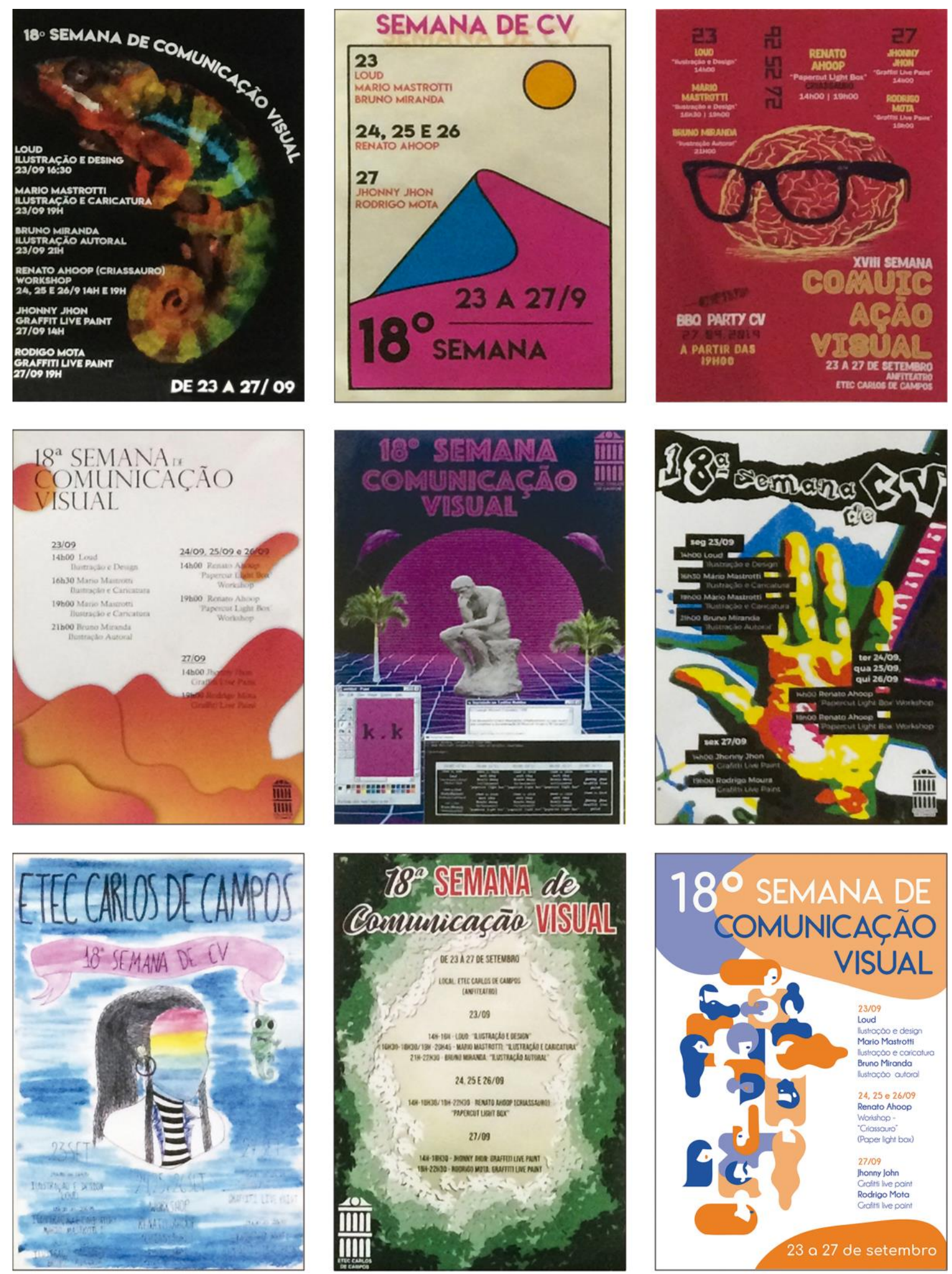

Figura 26:

projetos de cartaz em geometria irregular 

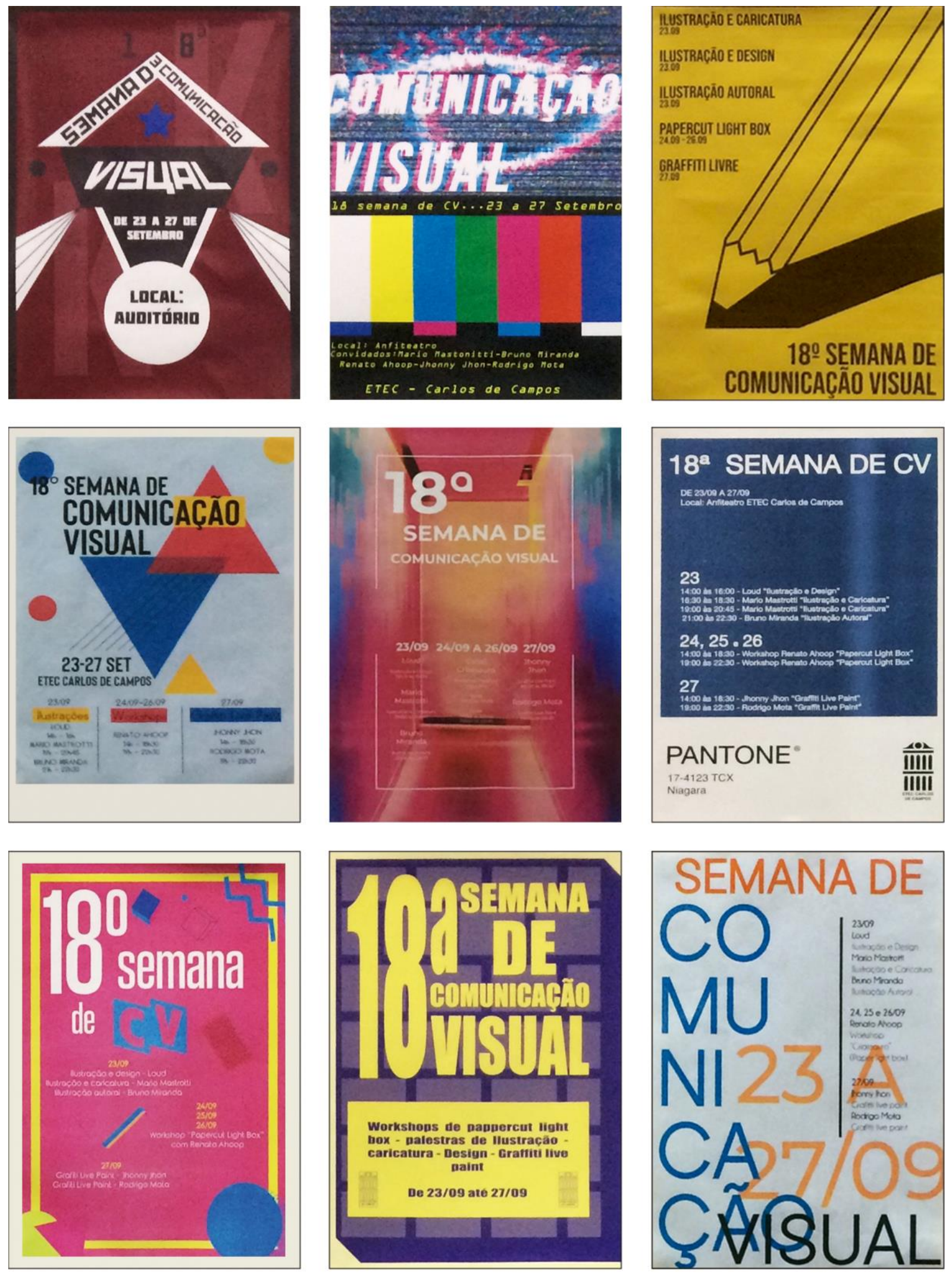

Figura 27:

projetos de cartaz em geometria regular 
Em apresentações de Trabalhos de Conclusão de Curso (TCCs) de escolas da rede Etec-SP, em que se conclui o grande projeto do semestre, as imagens digitais, em sua maioria, seriam estáticas, havendo pequenas animações executadas no aplicativo Flash. A partir de uma proposta da escola ou do professor responsável, os alunos desenvolveriam uma nova identidade visual de uma instituição cultural, envolvendo a criação de logotipos, símbolos gráficos e aplicações (itens de papelaria, cartazes, entre outros), como citado na seção 4.4.3.1.8 (Figura 28).

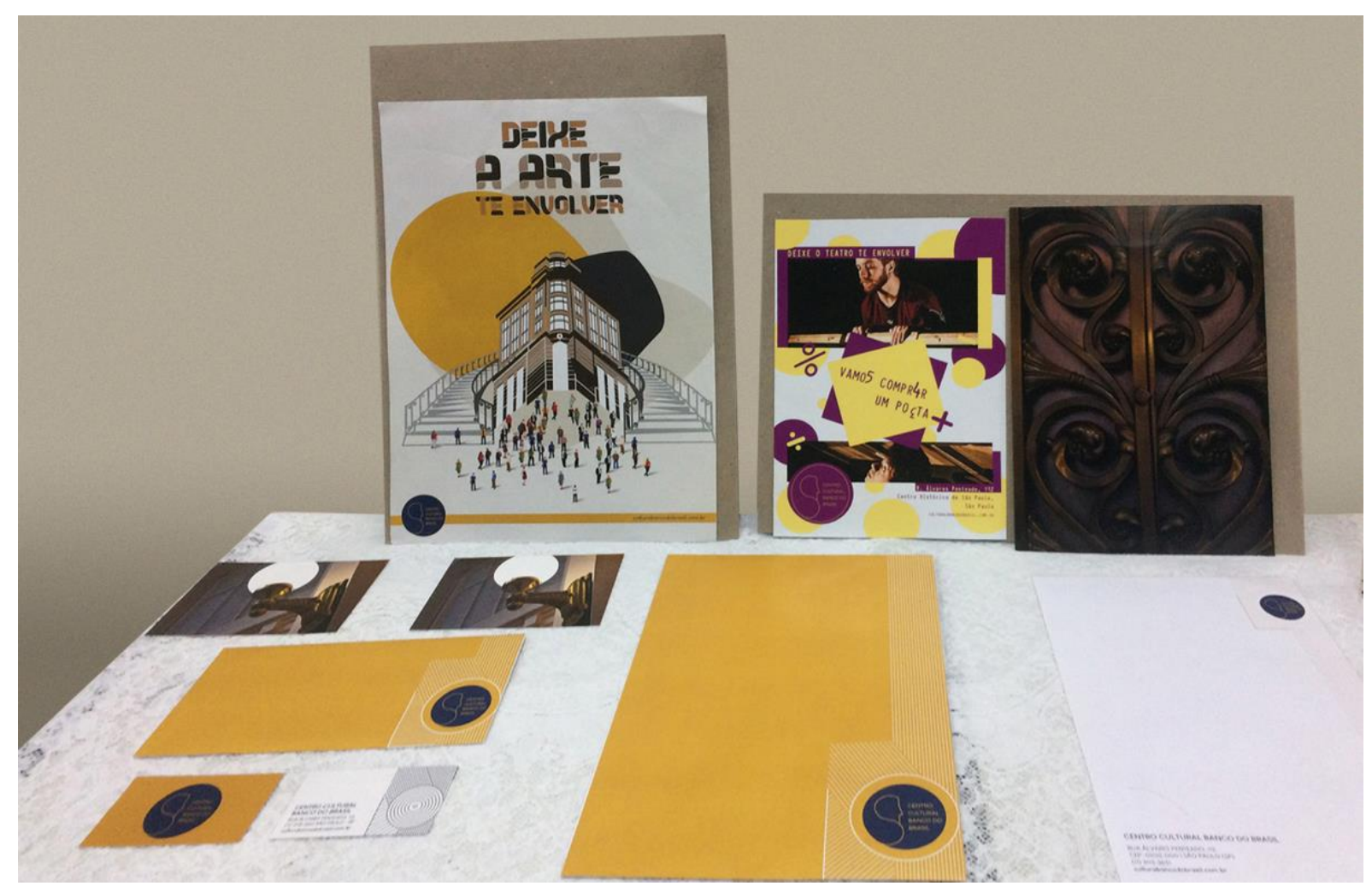

Figura 28:

projeto de identidade visual

Em se tratando de determinados projetos de identidade visual, os símbolos gráficos que as compõem se apresentam impropriamente resolvidos, em termos técnicos e gráficos, quanto a forma. É aparente, por exemplo, que em muitos desses projetos, sua redução afetará negativamente a legibilidade. Constatou-se, também, o que parece ser certo modismo formalista relativo à utilização de espaços aumentados entre elementos tipográficos, tornando a forma mais diluída, difusa e fragmentada. Nota-se, ainda, caráter mais ingênuo em certos projetos desenvolvidos a partir de elementos arquitetônicos menos representativos, apropriados diretamente nos símbolos gráficos (Figuras 29, 30 e 31). 


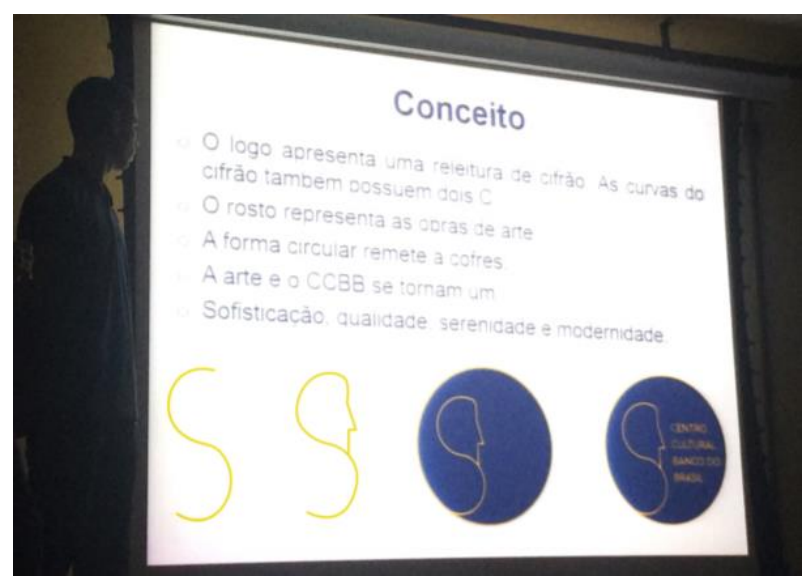

Figura 29:

projeto de identidade visual

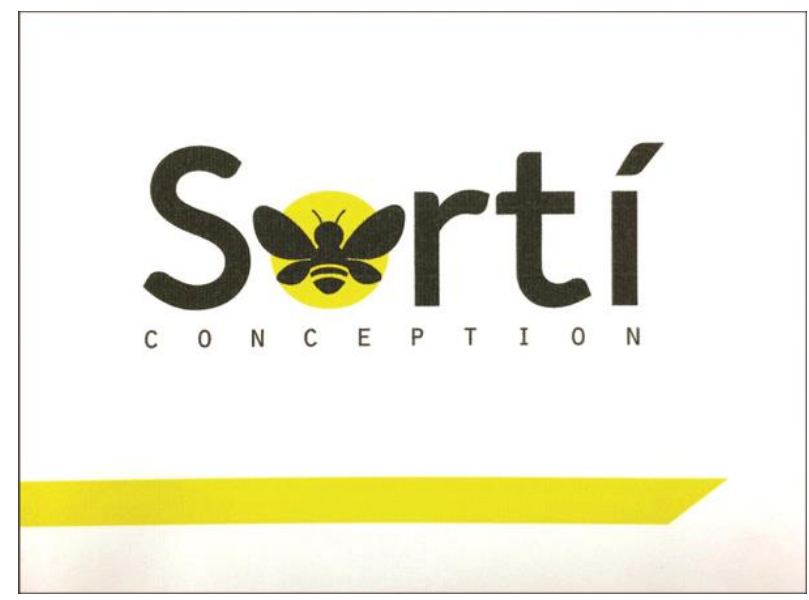

Figura 30:

projeto de identidade visual

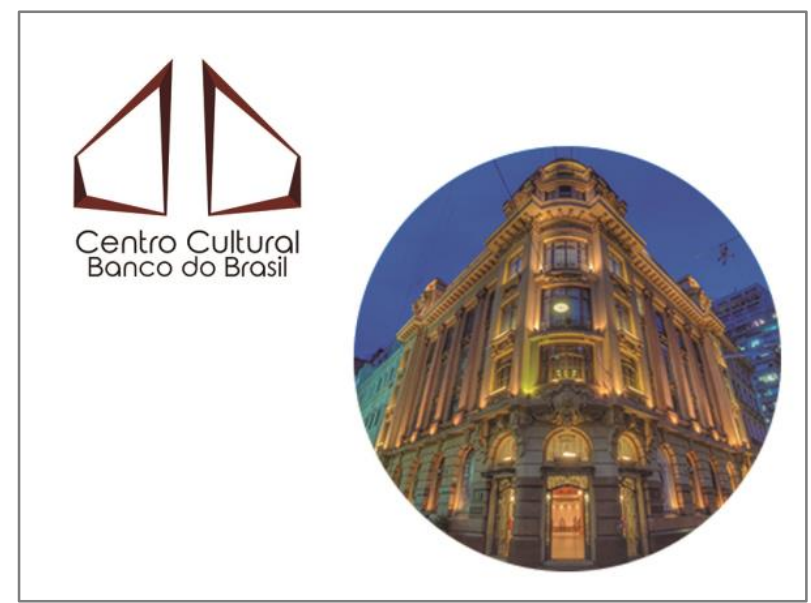

Figura 31:

projeto de identidade visual 
No caso de uma proposta de projeto apresentada por determinado professor, existiria demanda de desenvolver a figura de uma mascote. Esse elemento parece ser um componente comumente mais associado à linguagem de ilustração, animação, brinquedos infantis e histórias em quadrinho. Isto pressupõe presença de linguagem mais especialmente relacionada à publicidade e propaganda, posto que as embalagens dos produtos comerciais baseiam-se, cada vez mais, em mascotes, em personagens, altamente relacionados à cultura pop. Observou-se, ainda, em soluções desenvolvidas pelos alunos, preferência mais recorrente na caracterização de tais mascotes, de referências a crianças, muitas delas meninas e afrodescendentes, em linguagem gráfica nitidamente artística, naïf e infantilizada. Nas apresentações, percebeu-se predominância da cor branca no fundo dos slides. Os textos, em geral, justificados produziam, então, grandes espaços entre palavras, comprometendo, em certa medida, a composição como um todo (Figuras 32 e 33).

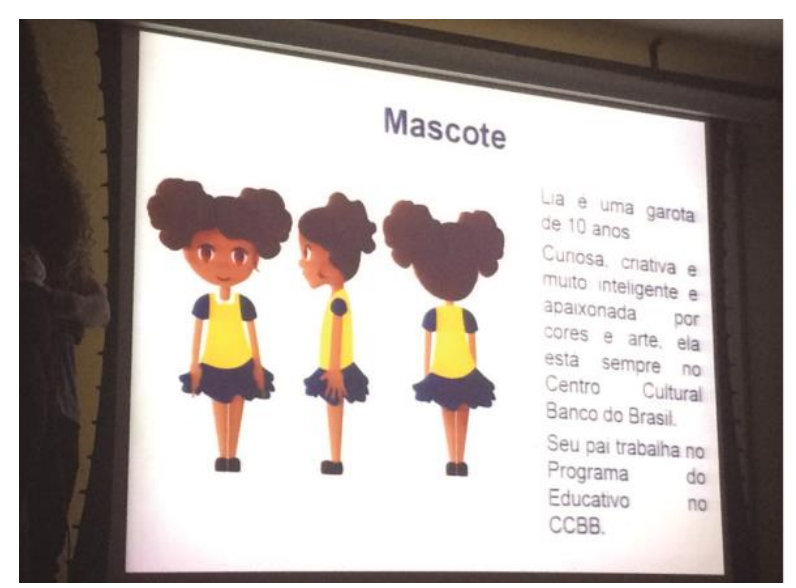

Figura 32:

desenvolvimento de mascote

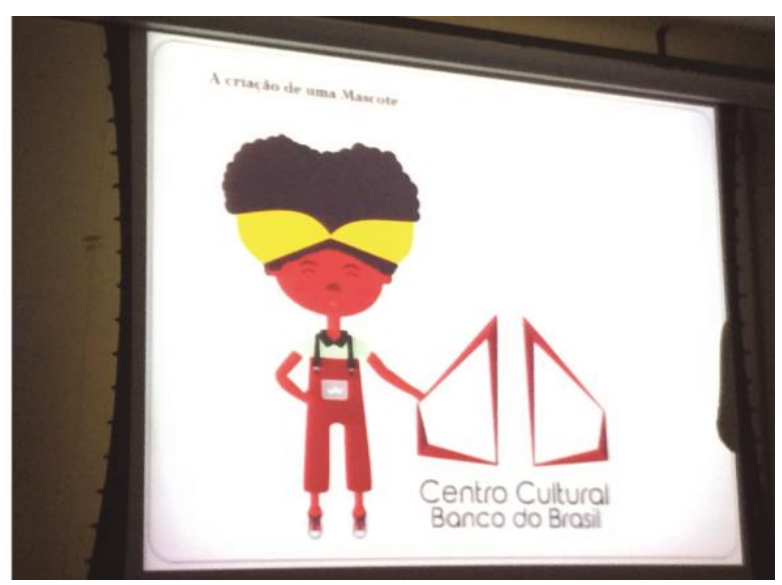

Figura 33:

desenvolvimento de mascote

Ao apresentar os trabalhos, a grande maioria dos alunos se expressava bem, com desenvoltura, fazendo boa defesa de seus projetos, o que corrobora a pedagogia de escolas técnicas: estimular o aluno a falar em plenário, uma vez que saber se expressar adequadamente seria um atributo bastante valorizado no mercado de trabalho. Outro ponto percebido é que, após as apresentações, os docentes que compunham a banca não faziam comentários, limitando-se a declarar que tudo estava muito bom. Por um lado, estariam incentivando o aluno a prosseguir em seus projetos; por outro, não parecia algo técnico, crítico, com um olhar mais construtivo. 
Exercícios com características mais manuais, de caráter empírico, mais comuns a propostas de professores da rede Etec-SP, tendem a ser realizados à mão livre, geralmente em folhas nos formatos $\mathrm{A} 4$ ou $\mathrm{A} 3$, com materiais e técnicas variadas, tais como grafite, nanquim, guache TGA, aquarela e tinta acrílica (Figuras 34 e 35). Os trabalhos, uma vez concluídos, costumam ser expostos nos corredores, exercendo função bastante semelhante à de obras de artes plásticas, em que a arte final é percebida como um fim a ser exposto, não como representação informativa de projeto.

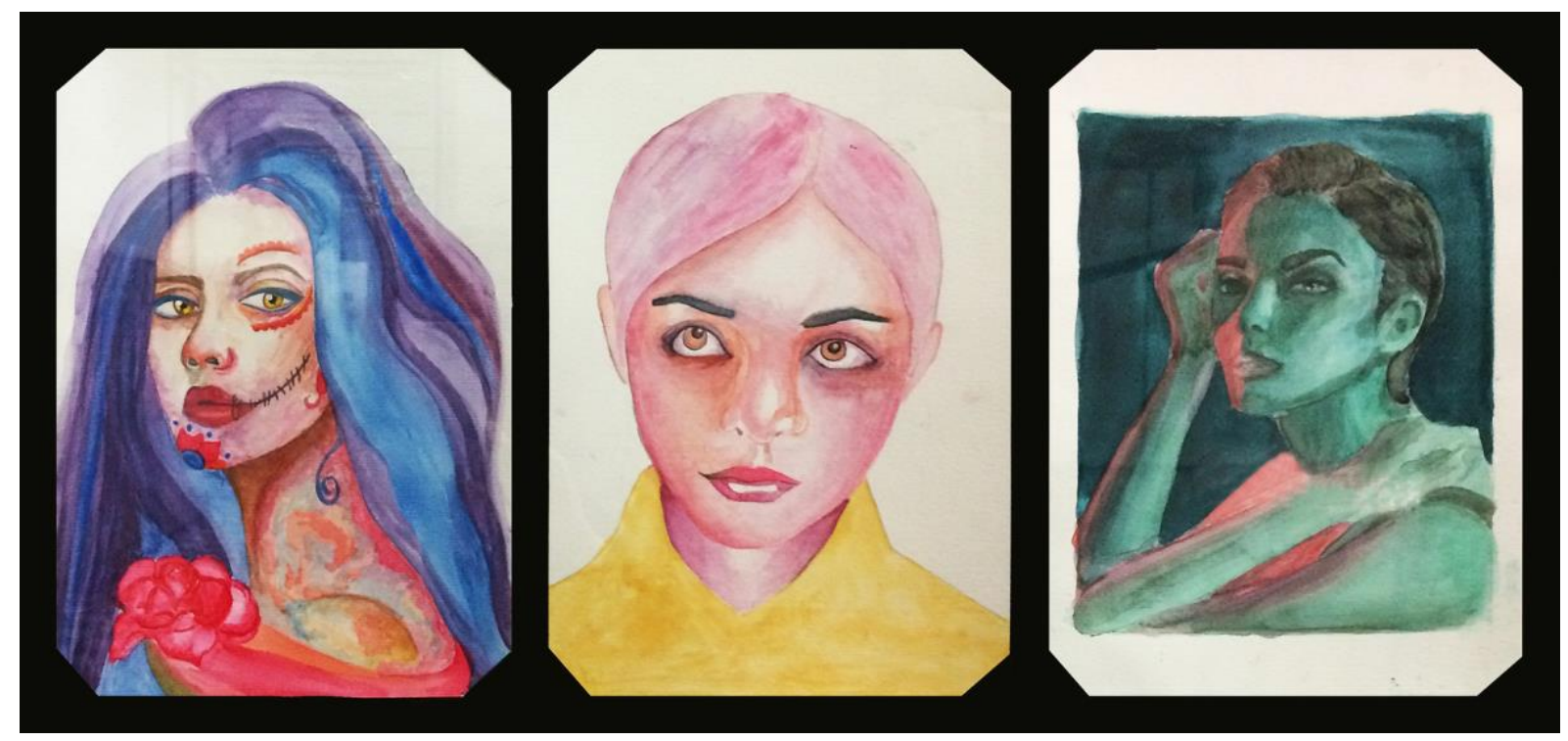

Figura 34:

exercícios de observação com técnica de aquarela

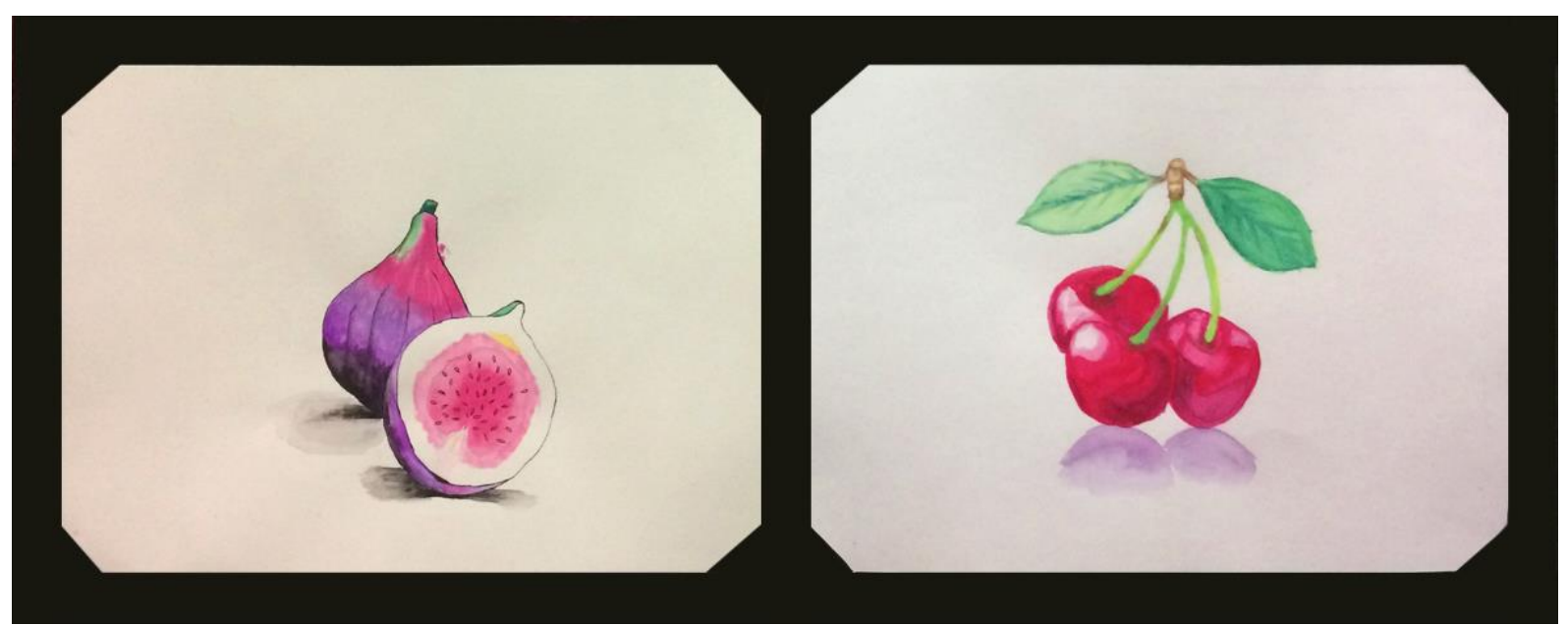

Figura 35:

exercícios de observação com técnica de aquarela 
Em composições desenvolvidas para projetos gráficos de revistas, observou-se emprego, além de elementos da tipografia e de elementos gráficos, de fotografias e ilustrações. As fotografias, muitas vezes, ocupariam a página inteira da revista, inclusive "sangrando" em suas bordas externas, verificando-se, ainda, utilização de tipografia de várias famílias diferentes em um mesmo projeto. Ainda, as manchas de texto estariam, em muitos casos, próximas às margens, evidenciando falta de "respiro" entre elementos, comprometendo, sobremaneira, a composição. Nestes projetos notou-se uma exploração de cores, aparentando, em alguns casos, não haver estudo prévio quanto a seu uso; em outros casos, parecia faltar unidade na identidade da revista, como, por exemplo, cada página ou seção com cores de padrão diferente (Figuras 36, 37 e 38).

Como anteriormente comentado, os projetos gráficos de revistas deveriam ser apresentados digitalmente, impressos e entregues em forma de boneco, o que se configura como problemático porque, apesar da obrigatoriedade de se entregar a revista impressa, as escolas da rede Etec-SP não ofereceriam nenhum auxílio aos alunos em relação à impressão.
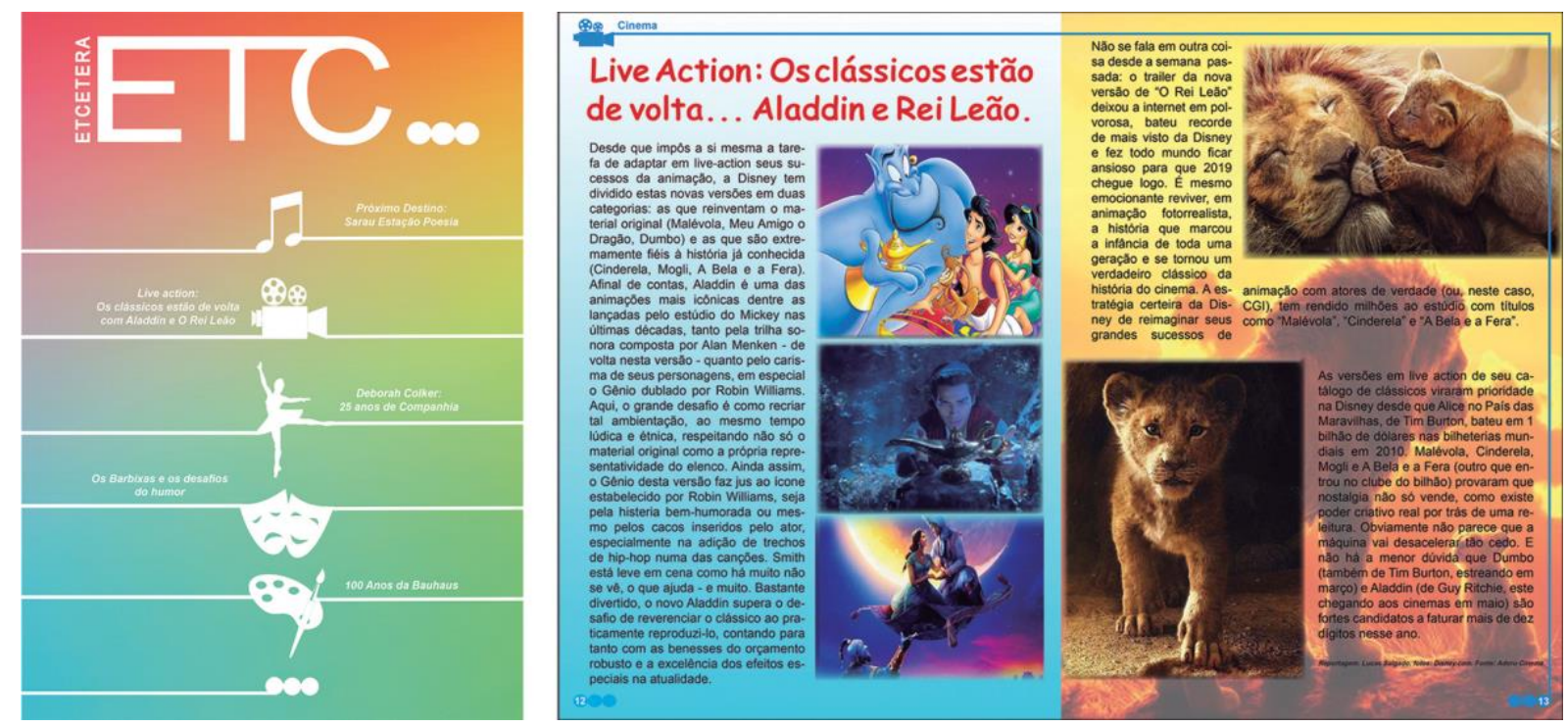

Figura 36:

projeto gráfico de revista (capa e folha dupla interna) 

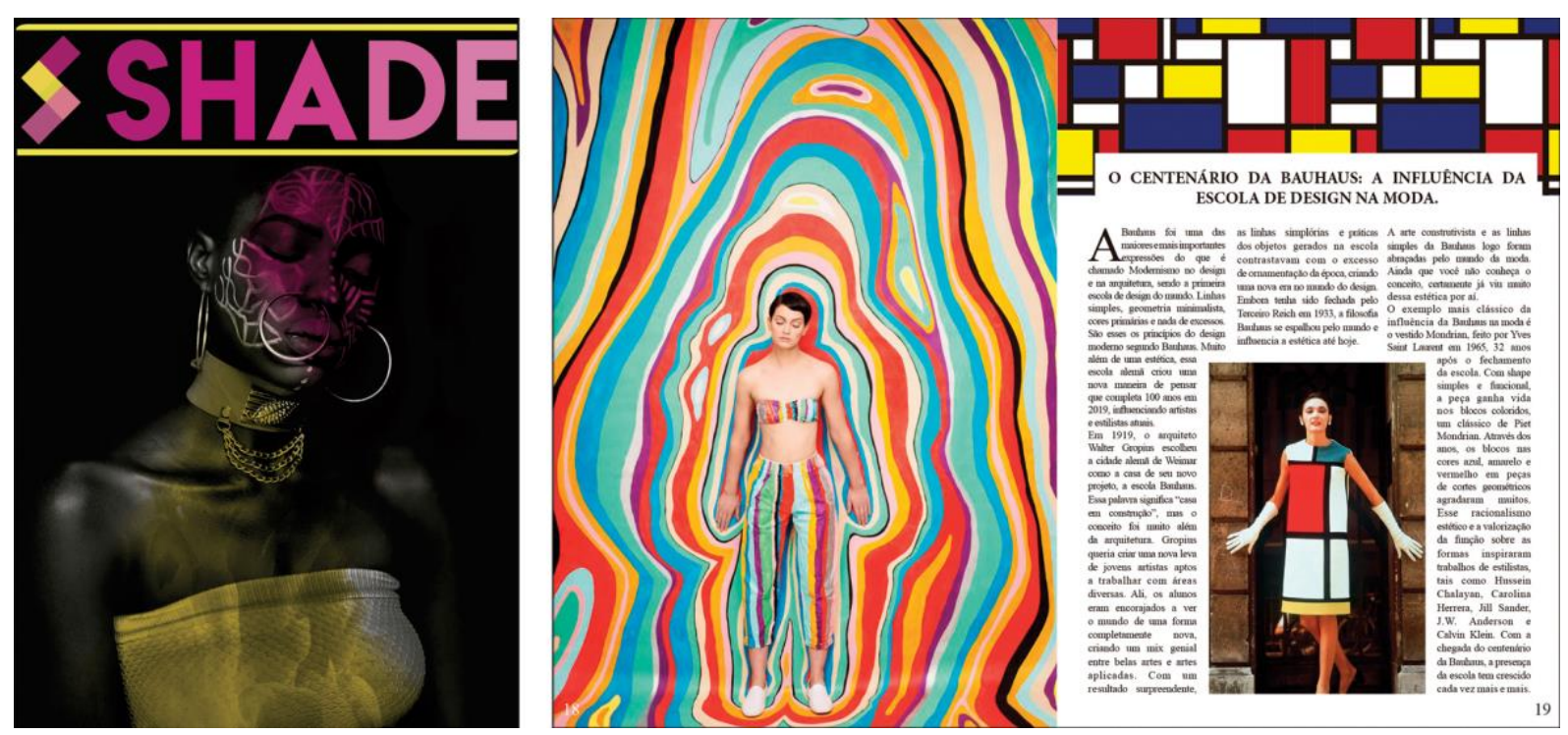

Figura 37:

projeto gráfico de revista (capa e folha dupla interna)
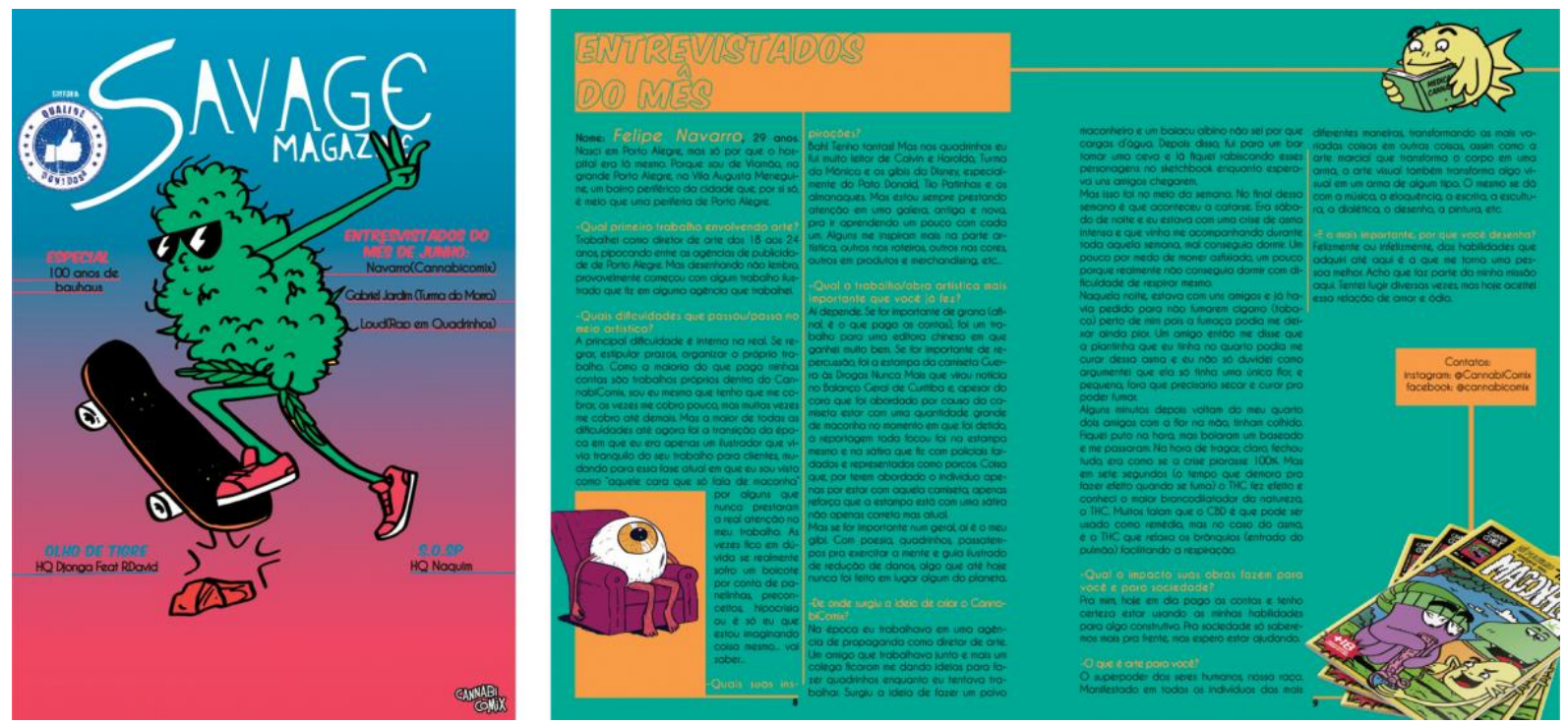

Figura 38:

projeto gráfico de revista (capa e folha dupla interna)

Notou-se, ainda, o que pareceu ser excessivo emprego da linguagem da ilustração, por exemplo, com utilização de fundos em dégradé (Figura 39). Os trabalhos elaborados pelos alunos não pareciam, neste sentido, apresentar domínio técnico da linguagem do design. De acordo com Villas-Boas (2009) e Gomes Filho (2009), a "harmonia" seria conferida pela lógica de uma organização coerente em todos os seus elementos, possibilitando leitura simples e clara, nem sempre evidenciada nos projetos observados. Percebeu-se também, em alguns casos, a utilização de elementos figurativos desenhados em substituição a alguma dada letra, 
comprometendo tanto a legibilidade quanto a linguagem mais limpa, neutra e elementar, mais características do design gráfico (Figura 40). A maioria dos trabalhos analisados revelava excesso de elementos compositivos irregulares, arbitrários, artísticos, com repertório formal mais associado ao universo da ilustração.

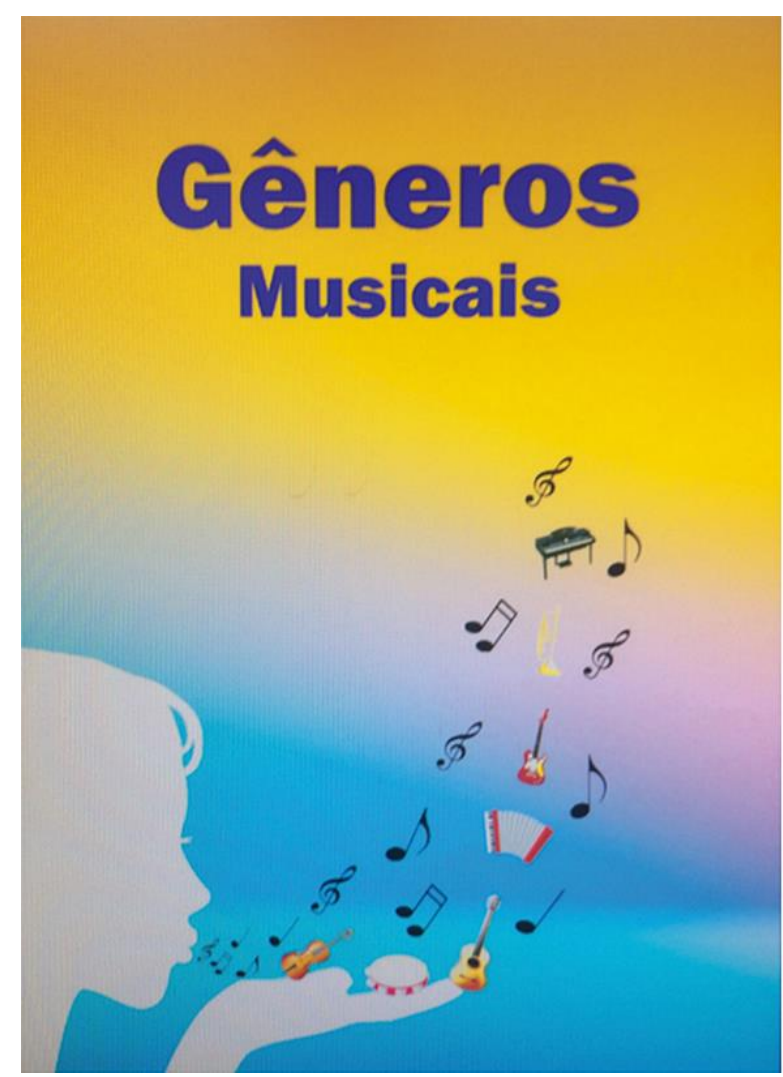

Figura 39:

projeto de cartaz

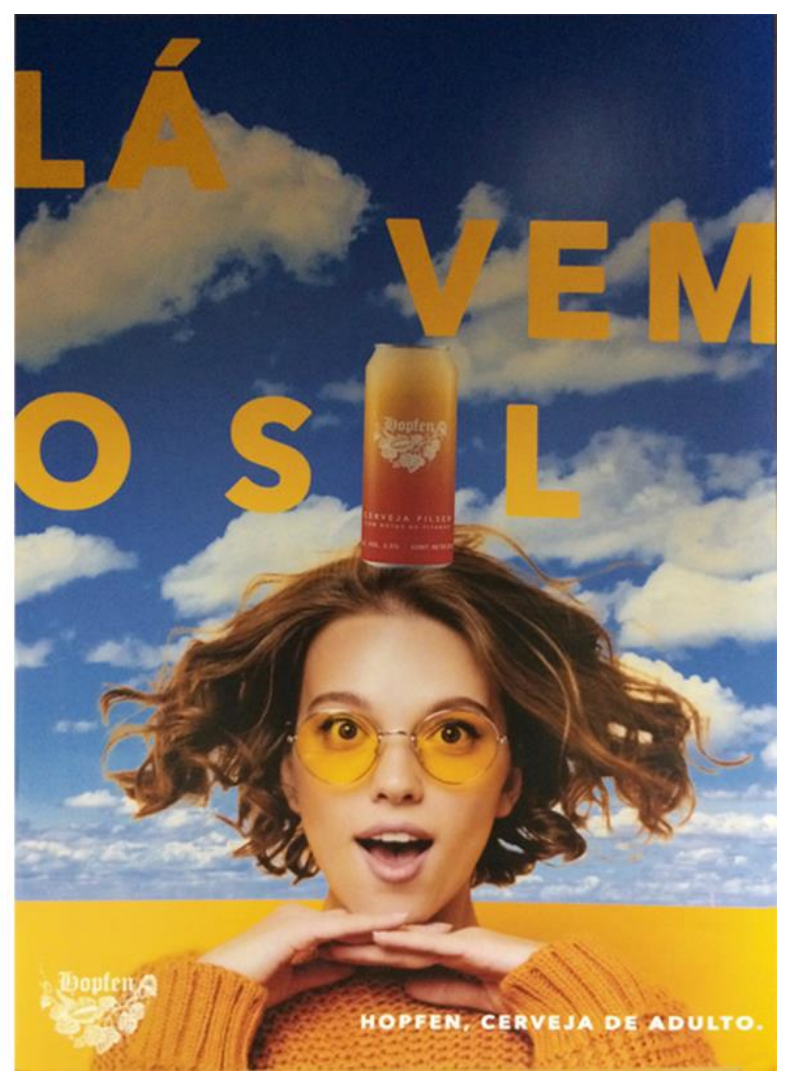

Figura 40:

projeto de cartaz

Os layouts tendem tanto a configurações orgânicas quanto a geométricas. Nota-se que as geométricas, em certos trabalhos, parecem sugerir certa falta de planejamento e da noção de programa. Observa-se, também, em parte dos projetos gráficos, em termos semânticos, relação entre significante e significado pouco clara, estável e universalmente compartilhada, como se esperaria em comunicações objetivas que caracterizam o ofício do design. Em alguns casos, identificou-se aplicação de fios sobre a tipografia, sugerindo tridimensionalidade, o que, em tais situações, parece produzir algum ruído na leitura. De modo geral, os trabalhos de alunos do Senac-SP pareciam mais elaborados, com maior atenção a aspectos técnicos. Não é discernível, na análise dos dados disponíveis, o quanto os projetos dos alunos tendem a se basear mais diretamente em referências visuais disponíveis na internet. Neste sentido, 
foi relatado que, alunos, em algumas situações pedagógicas, seriam orientados a "formar repertório" a partir de trabalhos notáveis de profissionais de design gráfico.

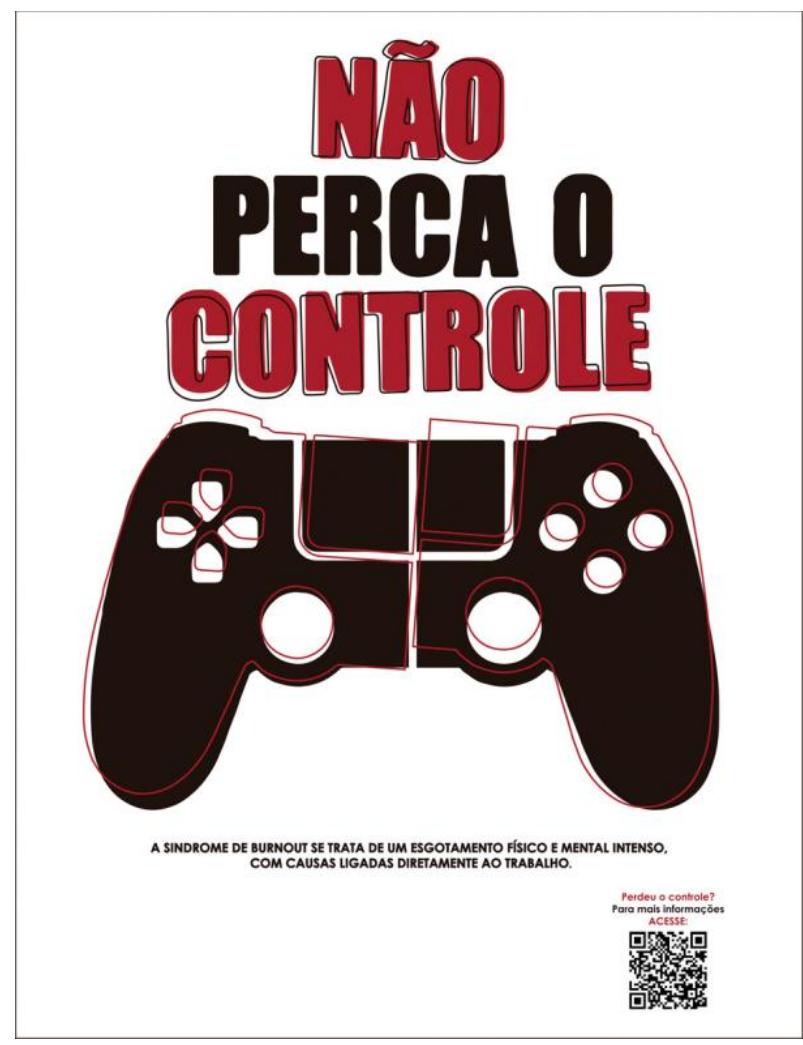

Figura 41:

projeto de cartaz

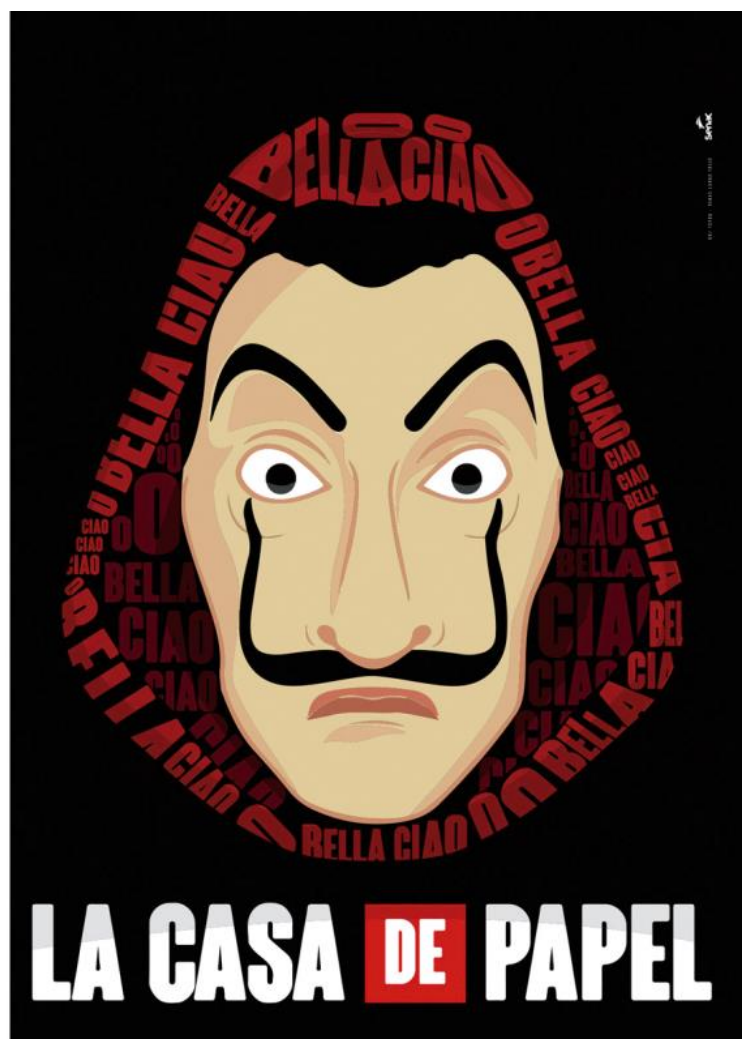

Figura 42:

projeto de cartaz "All Type"

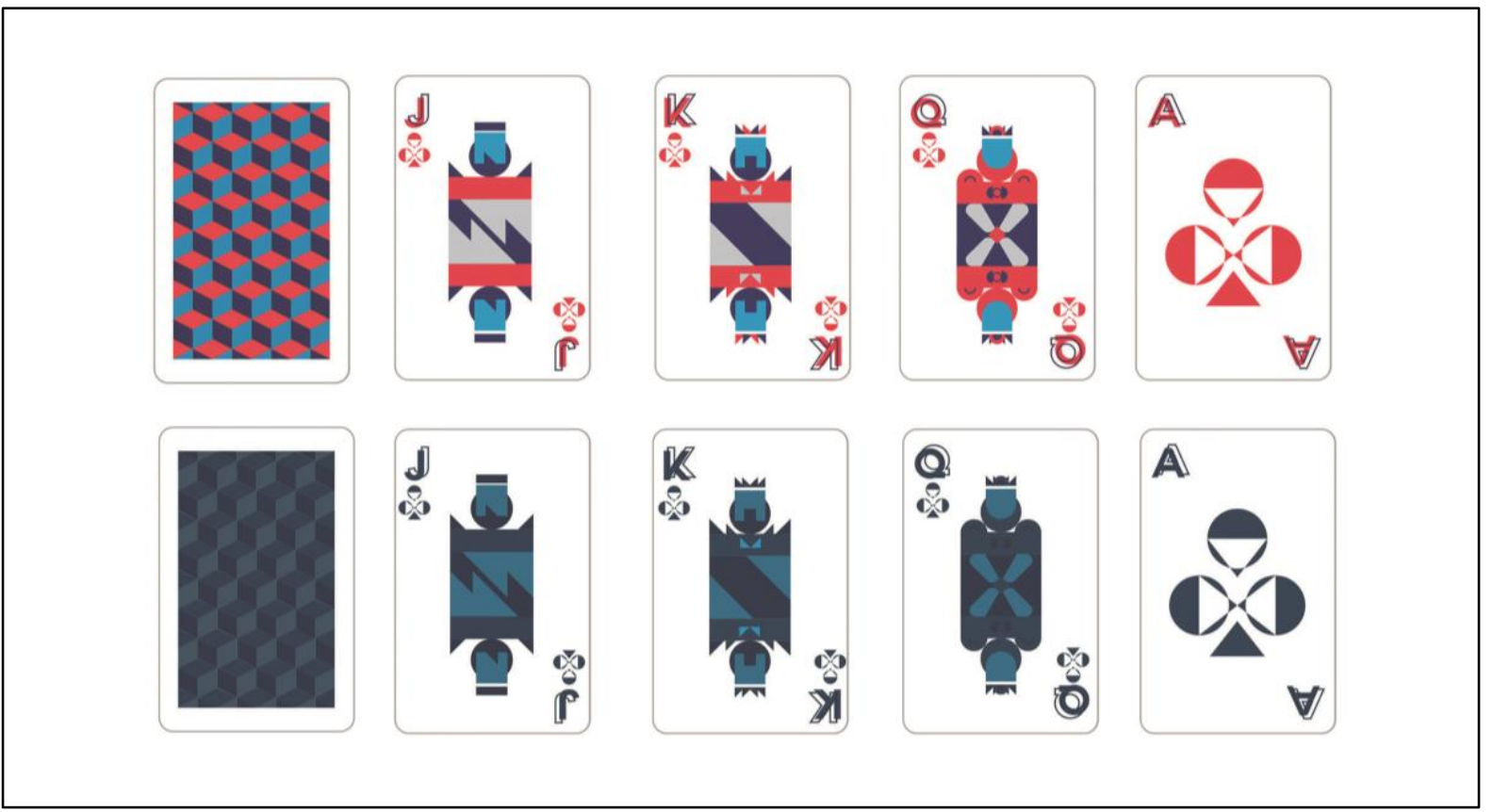

Figura 43:

projeto gráfico de baralho 
Em termos mais gerais, os trabalhos analisados parecem incorrer em linguagem relativamente ingênua e evocativa, em significativa parcela dos casos, de categorias poéticas das artes plásticas, com perceptíveis inadequações técnicas e funcionais em seus layouts de composições tipográficas. Apesar disto, em termos criativos e artísticos, alguns trabalhos evidenciariam certo talento e vocação por parte dos alunos que os conceberam. O emprego de elementos gráficos, de imagens e, sobretudo, de tipografia de modo relativamente acidental, arbitrário, subjetivo, de volição pessoal e caprichoso, destituídos, ao menos em parte, de preocupações com modulação, regularidade, clareza, coerência sintática, síntese e unidade formal, pareceria, assim, menos característico do registro próprio da especificidade metodológica, linguística, funcional e estética do design. 


\section{7}

\section{Resultados concernentes ao subproblema 7}

(questões ainda mais gerais)

\subsection{1}

\section{Objetivos e ideários do ensino técnico de design gráfico}

Os dados analisados na categoria temática apresentada nesta seção foram agregados, inicialmente, em função dos objetivos e ideários do ensino técnico de design gráfico: uma com base em documentos institucionais públicos e outra a partir da visão de professores. Por sua vez, no interior de cada uma destas duas subseções produzidas, separaram-se os dados analisados em subseções correspondentes às duas principais redes de escolas técnicas cobertas pela pesquisa: a Etec-SP e o Senac-SP.

\subsubsection{1}

Objetivos e ideários do ensino técnico de design gráfico com base em documentos institucionais públicos

\subsubsection{1}

\section{Objetivos e ideários do ensino técnico de design gráfico com base no Plano de Curso da Etec-SP}

Segundo o Plano de Curso para Habilitação Profissional de Técnico em Comunicação Visual do Centro Estadual de Educação Tecnológica Paula Souza, o objetivo mais geral deste Curso nas escolas da rede Etec seria: "capacitar o profissional para criar e executar projetos gráficos em consonância com as necessidades do cliente, utilizando as tecnologias que maximizem os recursos materiais, humanos e econômicos". Observe-se que a Etec se propõe a preparar seus alunos em termos profissionais não apenas para executar aspectos mais mecânicos e técnicos, mas também para criação propriamente dita de projetos gráficos, sugerindo a ideia de que sairiam qualificados para uma atuação mais global no mercado de trabalho. 
A proposta, ao que parece, seria atender a demandas de clientes, não havendo menção, mais especificamente, aos usuários finais do projeto, nem à sociedade como um todo, em área projetual como a do design.

Além disso, pretende-se capacitar para: "executar programação visual de diferentes gêneros e formatos gráficos para peças publicitárias como livros, portais, painéis, folderes, jornais". Este segmento sugere intenção em expor os alunos a várias modalidades de projetos gráficos. Entretanto, o espectro mais diversificado não parece exatamente incluir peças publicitárias, uma vez que livros, painéis, folderes e jornais seriam projetos mais restritos ao design gráfico em si. A Etec-SP também defende a importância de se conhecer e empregar as leis relacionadas à área: "interpretar e aplicar legislação, orientações e normas específicas da comunicação visual". Isto sugere cuidado da instituição em passar aos alunos orientações legais que regeriam a área.

O Curso, ainda, pretende capacitar seus alunos para: "elaborar projetos de design com ênfase na inovação e na criação de novos processos". Tendo em vista que o Curso se destinaria, sobretudo, a estudantes do ensino médio ou a indivíduos com pouco conhecimento da área, a ênfase sugerida em inovação e criação de novos processos em projetos parece um pouco difícil de ser concretizada. O último item do programa apresentaria foco na área da comunicação: "utilizar a comunicação visual, escrita e verbal". Esta proposta de capacitação não apenas visual como também verbal dos processos de comunicação parece indicar cuidado com a formação mais completa de alunos.

Chama atenção o fato de que o Plano de Curso que rege o Curso Técnico em Comunicação Visual das escolas da rede Etec-SP confira especial atenção ao aspecto generalista, o que estaria em correspondência com o fato de que muitos professores não seriam formados especificamente na área do design, apresentando graduações mais diversificadas. Destaque-se, ainda, a importância considerada ao papel do cliente (e não ao de usuários finais dos projetos). Observe-se, também, relevância atribuída ao ensino de normas e da legislação concernente à atuação profissional de designers, bem como a aspectos de capacitação visual e verbal em processos de comunicação de um modo geral. 


\subsubsection{2 \\ Objetivos e ideários do ensino técnico de design gráfico com base no Plano de Curso do Senac-SP}

Por sua vez, o Senac-SP, de acordo com seu Plano de Curso para Habilitação Profissional Técnica de Nível Médio em Comunicação Visual, apresenta, como objetivo geral, preocupação, ao que se depreende, com uma formação técnica mais pragmática: "Formar profissionais com competências para atuar e intervir em seu campo de trabalho, com foco em resultados". Isto sugere valorização, por parte do Senac-SP, de aproximar seus alunos do mercado efetivo de trabalho em circunstâncias mais reais.

Quanto a seus objetivos específicos, o Curso do Senac-SP visaria capacitar seus alunos no sentido de agregar valores e conhecimentos técnicos a seus trabalhos. Segundo seu Plano de Curso, também, um de seus objetivos seria o de: "Promover o desenvolvimento do aluno por meio de ações que articulem e mobilizem conhecimentos, habilidades, valores e atitudes de forma potencialmente criativa e que estimule o aprimoramento contínuo". O texto citado sugere preocupação com formação de profissionais mais ágeis e polivalentes, capazes de aplicar, em seus projetos, conhecimentos que associem aspectos técnicos a, por exemplo, questões sociais e ambientais. Pressupõe que o Curso procuraria, ainda, promover valores e competências de sociabilidade, trabalho em equipe e colaborativo entre seus alunos.

O texto do seu Plano de Curso também registra que o Curso igualmente procuraria incentivar o aluno a realizar projetos com cunho ambiental e social: "Estimular, por meio de situações de aprendizagens, atitudes empreendedoras, sustentáveis e colaborativas nos alunos". Este fragmento parece reiterar a já mencionada ênfase do Curso quanto a formar alunos para o mercado de trabalho com sensibilidade para questões ambientais e sociais. Seu Plano de Curso ainda aponta para a importância de combinar funções de comunicador visual com projetos que incentivem o pensamento analítico e a capacidade de decisão dos alunos. Seu texto sugere, neste sentido, o propósito de: "Articular as competências do perfil profissional com projetos integradores e outras atividades laborais que estimulem a visão crítica e a tomada de decisão para resolução de problemas". Este trecho 
parece indicar preocupação do Senac-SP em associar atribuições mais técnicas correspondentes ao profissional de comunicação visual com qualidades consideradas relevantes, tais como capacidade crítica e determinação para atingir objetivos profissionais.

O Curso se dispõe, também, a: "Promover uma avaliação processual e formativa com base em indicadores das competências, que possibilitem a todos os envolvidos no processo educativo a verificação da aprendizagem". Este trecho trata da importância conferida, ao menos publicamente, pelo Senac-SP a processos avaliativos baseados em pareceres técnicos e objetivos, considerando os alunos como agentes de sua formação. Por fim, seu Plano de Curso ainda menciona o estímulo à pesquisa para fortalecimento do aprendizado, como no trecho: "Incentivar a pesquisa como princípio pedagógico e para consolidação do domínio técnico científico, utilizando recursos didáticos e bibliográficos". Esta passagem extraída de seu Plano de Curso pressupõe a proposta do Senac-SP de conscientizar seus alunos a respeito da importância de se manterem atualizados, ampliando, permanentemente, seus conhecimentos.

Dentre os pontos mais significativos do Plano de Curso do Senac-SP, observe-se a ênfase na formação de profissionais capacitados e sensíveis a questões sociais e ambientais, bem como conscientes do valor do estudo contínuo, buscando, assim, oferecer condições mais próximas à prática profissional, o que, presumivelmente, facilitaria a inserção de seus egressos no mercado de trabalho.

\subsubsection{2}

\section{Objetivos e ideários do ensino técnico de design gráfico com base na visão de professores}

\subsubsection{1}

Perspectivas de respondentes associados a escolas da rede Etec-SP

De acordo com a Respondente 1, professora, mencionando a viabilidade de se ensinar design para jovens, informou que o propósito do curso seria "[...] conseguir 
que ele entenda a área, que ele tenha todo o repertório que ele precisa, porque é uma área muito ampla. [...] mas ele vai ter várias disciplinas depois, [...] que vão habilitar pr'a diversas áreas". Esta fala sugere que o objetivo do curso seria, a princípio, formar repertório da área da comunicação visual para, posteriormente, criar e executar projetos gráficos. Neste sentido, a mesma Respondente 1 mencionou a proposta de um projeto gráfico, desenvolvido em grupo: "A gente trabalha bastante aqui com o projeto interdisciplinar 'Revista'. Ela é digital e impressa. Porque o aluno, tudo o que ele viu lá em composição no $1^{\circ}$ módulo, toda a teoria que ele viu, ele aplica na hora de diagramar uma página". Este trecho do seu depoimento sugere que um dos objetivos do Curso seria proporcionar vivências similares ao que os alunos iriam encontrar no mercado de trabalho, capacitando-os a trabalharem em equipe com pessoas de diferentes especialidades.

\subsubsection{2}

\section{Perspectivas de respondentes associados a escolas da rede Senac-SP}

Segundo a Respondente 29, professora já citada, "O foco do Curso é [o de] formar profissionais pr'a área, incluso a parte de atitude, valores, o comportamento no mercado de trabalho" e, quanto aos alunos, "[...] alguns querem mudar de área, gostou de design, aí, eles vêm fazer o curso. [...] A gente não forma 'micreiros', a gente forma designers". De modo análogo, a Respondente 30, outra professora, informou que o Curso visa a conferir autonomia criativa e profissional mais ampla a seus formandos. De acordo com ela, "O curso objetiva formar profissionais. Essa iniciação geral vai do estado de espírito de quem 'tá na aula. Nós ensinamos p'ra que o cara seja contratado em algum lugar e assuma que é um assistente de arte, que é um designer". Ainda, a Respondente 30 indicou que nem todos os alunos se destinariam ao mercado de trabalho especificamente de design. Para ela, "Tem esses que vem p'ra saber como é que é, ter uma noção geral ou que 'tá, por exemplo, fazendo uma graduação em marketing e gostaria de saber um pouco mais sobre criação p'ra poder defender suas ideias ou amparar a turma de criativos".

Com base nestes depoimentos, muito semelhantes, parece que o objetivo maior do curso seria o de capacitar os alunos para rápido ingresso no mercado de trabalho. 
Já os objetivos dos alunos variariam, principalmente, entre três fatores: desejo de mudar de área, de descobrir possível afinidade com a comunicação visual ou, ainda, de ampliar o conhecimento em áreas afins à de suas formações originais, possibilitando melhor adaptação profissional.

\subsection{2}

\section{Papel percebido do ensino técnico na atividade profissional do design}

Os dados analisados na categoria temática apresentada nesta seção foram separados em subseções correspondentes às duas principais redes de escolas técnicas cobertas pela pesquisa: a Etec-SP e o Senac-SP.

\subsubsection{1}

\section{Perspectivas de respondentes associados a escolas da rede Etec-SP}

Em relação ao papel percebido do ensino técnico na atividade profissional do design, o Respondente 4, professor, mencionou que seria a base para o aluno obter noções mais elementares, com ênfase na prática. Segundo ele, "A prática vai ser a mola propulsora p'ra ele estar entrando no mercado de trabalho. [...] mesmo ele tendo uma teoria rasa, quando ele vai p'r'o curso superior, ele acaba tendo contato com a teoria complexa, então, isso melhora o que ele aprendeu na prática". De acordo com este depoimento, o curso técnico, apesar de não se aprofundar em questões teóricas, proporcionaria habilidades práticas ao aluno, possibilitando-lhe acesso ao mercado de trabalho. Isto sugere que, ao ingressar no ensino superior já tendo vivenciado a prática, ele potencialmente compreenderia a teoria mais facilmente.

Por outro lado, o mesmo Respondente 4 acreditaria não existir, no dado momento, mercado de trabalho na área do design. Segundo ele, "Eles [alunos] vão ter que começar a interagir ali, com o lugar que moram, com as pessoas, com os amigos, porque se não houver essa interação, não tem emprego e não tem trabalho". Sua declaração parece indicar que o emprego formal no mercado profissional do design estaria escasso. Neste sentido, a indicação da necessidade de manterem 
contato com pessoas próximas sugere preocupação desse respondente com o futuro profissional de seus alunos.

De maneira similar, o Respondente 6, outro professor, comentando a respeito da importância do ensino técnico de comunicação visual, informou que o Curso cobriria várias frentes na formação em design. De acordo com ele, "Que estejam bem amparados pelas tendências atuais, acompanhando o que tem de mais recente, estar aplicando design de maneira original, atendendo aos clientes, ao mercado, às editoras, às agências da melhor maneira possível". Seu relato sugere que o propósito do ensino técnico de design seria qualificar novos profissionais para o mercado de trabalho, destacando a importância de os alunos estarem constantemente se atualizando.

Tal ponto de vista está em clara oposição ao do Respondente 14, um aluno, que mencionou se sentir meio perdido em relação ao mercado de trabalho. Segundo ele, "P'ra um curso técnico, ele deveria 'tê' mais força no mercado, porque a gente sai daqui sem saber o que vai ser depois que se formar. Acho que a visão do mercado, p'ra quem faz o [curso] técnico, ela 'tá meio preconceituosa". Sua declaração sugere percepção de que o mercado de trabalho não valorizaria a formação em cursos técnicos, não parecendo claro se seria em razão do diploma concedido ou em função da natureza do ensino.

\subsubsection{2}

Perspectivas de respondentes associados a escolas da rede Senac-SP

A Respondente 29, professora, ao comentar a respeito da estruturação do programa do curso técnico de comunicação visual, informou que seria dividido em quatro qualificações técnicas: "[...] alguns se identificam mais com embalagens, outro mais com editoração, outros com diagramação, cada um pode especializar em uma área diferente. Mas tem alunos que conseguem a vaga de trabalho fazendo o técnico, conseguem entrar na área". De modo similar, como já citado na seção 4.4.1.1.2, a Respondente 32, outra professora, realçou que o curso haveria se desmembrado. Para ela, "[...] o curso foi segmentado por falta de tempo das pessoas. Para as 
pessoas tentarem conseguir um emprego com um curso de qualificação".

Estas declarações sugerem que a estruturação do currículo e a possibilidade de cursar uma qualificação técnica específica, mais especialmente relacionada aos interesses de cada aluno, favoreceria sua inserção no mercado de trabalho.

Por outra perspectiva, a mesma Respondente 30 declarou acreditar na relevância da dimensão social do ensino técnico de design na atividade profissional do design: "Você começa a objetivar as formas de uma maneira mais assertiva. Você melhora a sua casa, é comunicação, é mensagem. Então, melhora a forma de você se expressar para o mundo. Atende à necessidade do outro, porque você é coautor". Esta afirmação sugere compreensão da abrangência do ofício do design, visto como atividade transportadora, capaz de intervenções positivas na realidade, sobretudo quando o designer se volta para projetar soluções para o outro.

Os dados comentados acima sugerem que o foco do ensino técnico de comunicação visual das escolas da rede Senac-SP seria o de preparar seus alunos para sua inserção no mercado de trabalho, seja promovendo a flexibilização de percursos formativos, seja conscientizando seus alunos da dimensão da atividade do design, inclusive no âmbito do social.

\subsection{3}

Relação entre ensino técnico e ensino superior de design gráfico e de áreas afins

Os dados analisados na categoria temática apresentada nesta seção foram separados em subseções correspondentes às duas principais redes de escolas técnicas cobertas pela pesquisa: a Etec-SP e o Senac-SP.

\subsubsection{1}

\section{Perspectivas de respondentes associados a escolas da rede Etec-SP}

Em se tratando da relação entre ensino técnico e ensino superior de design gráfico, a Respondente 1, professora, afirmou que: "[...] a faculdade é muita teoria". Para ela, 
"Você aprende, em detalhe, todos os teóricos, toda a evolução e, no técnico, você adapta a área. Você procura trazer elementos lá da comunicação p'ra área de design gráfico, você, de uma certa maneira, tenta trazer p'r'o lado prático". A mesma Respondente 1 enfatizou que o foco do ensino técnico seria a execução de projetos e que os alunos já ingressariam com espírito de produção. Este trecho do seu depoimento sugere que parte significativa de alunos de cursos técnicos de comunicação visual assimilariam mais facilmente conceitos durante o processo de desenvolvimento de projetos.

A este respeito, a Respondente 24, ex-aluna, declarou perceber diferença de abordagem em projetos de design no ensino técnico e na graduação. Para ela, "No técnico, era uma coisa rápida. Era mais: execute, execute! [...] [Na faculdade] é totalmente diferente. Pensa-se muito mais antes de sair fazendo. Tem a pesquisa antes, tem um preparatório. Projeto de design teórico, um pouco de história". Sua fala pressupõe que não seriam ministradas aulas do método clássico de projeto em design em cursos técnicos de comunicação visual. A Respondente 25, outra ex-aluna, como visto no item 4.5.1.1, de modo similar, mencionou a percebida ênfase em projetos de design em sua faculdade. Segundo ela: "[...] focam bastante em metodologia de projeto, que é uma coisa que eu não tive no técnico. Por semestre, cada professor fala do projeto em si, a metodologia que a gente vai seguir". Estas declarações parecem indicar que a valorização do aparato metodológico característico do campo do design - por exemplo, a disposição preliminar disciplinada aos alunos das diferentes fases de projeto, assim como a forma como elas se articulam sequencialmente -, apenas ocorreria no domínio do ensino superior, não alcançando o estágio dos cursos técnicos. Isto sugere existência de uma lacuna com respeito à metodologia de projeto no âmbito do curso técnico.

A mesma Respondente 24, relatando uma experiência significativa no ensino superior, realçou a abordagem do design no âmbito social. Para ela, "Na faculdade, a filosofia do design, acho que foi a coisa que mais 'pá'! O impacto social, a complexidade do design na sociedade". Baseando-se em conversas com alunos de faculdades particulares de design, a própria Respondente 24 declarou que não se atingiria nível equivalente de discussão em algumas destas instituições. Este relato pressupõe que a filosofia do design, percebida como impactante por essa respondente, 
não seria abordada em cursos técnicos de comunicação visual, possivelmente por prescindir de grau mais elevado de amadurecimento dos alunos.

A Respondente 23, outra ex-aluna, citando determinados conteúdos, tais como Gestalt e Bauhaus, tratados tanto no ensino técnico como na graduação, informou perceber diferença de abordagem. Para ela, "É claro, que no [curso] técnico, é muito mais superficial. Aí, na faculdade, você realmente se aprofunda. [...] Às vezes, você fala: Ah, isso aqui eu já vi antes". Este trecho do seu depoimento sugere que a abordagem teórica dos cursos técnicos consistiria em apresentar parte dos conceitos da área da comunicação visual aos alunos de maneira mais breve, introdutória, uma vez que o foco do ensino técnico estaria na parte executiva. Pressupõe, também, que seus estudantes seriam, em sua maioria, ainda muito jovens para internalizar conceitos percebidos como mais complexos.

Por outra perspectiva, a Respondente 28 , também ex-aluna, quanto à contribuição dos dois cursos para sua formação, revelou que cada um teria seu valor. Segundo ela, "O técnico foi um bom pano de fundo, me apresentar coisas, ter uma boa noção de mercado, como as coisas funcionam, até onde você pode ir. E, na faculdade, foi mais uma constatação de tudo que me foi apresentado". Esta fala pressupõe que o curso técnico seria percebido como sendo uma introdução à área, com ênfase no preparo para o mercado de trabalho. Quanto à graduação, especificamente em design gráfico, a mesma Respondente 28 expôs seu ponto de vista: "A faculdade, ela vem p'ra aprofundar. P'ra explicar uma série de coisas e te gerar uma outra linha de raciocínio, que é muito p'ra vida. [...] design gráfico é um curso p'ra vida. [...] te ensina muitas coisas: do material ao projetual, ao produto final". Seu relato sugere que a graduação em design gráfico, além de um meio para desenvolvimento de competências e habilidades específicas para atuação na área, seria potencialmente capaz de preparar o indivíduo para outras demandas de sua existência.

Comentário semelhante ao da Respondente 1, apresentou outro professor, o Respondente 6, embora informando que sua formação seria em artes plásticas: "Estou supondo, pelo o que eu ouço, que na faculdade de design é mais voltada p'ra parte teórica que a parte prática". Neste sentido, exemplificou que o ensino de aplicativos gráficos na graduação em design, seria o "ABC da coisa" e, por vezes, 
parte dos alunos procurariam cursos extras, fora da faculdade, para conseguir executar os trabalhos propostos. Segundo ele, "[...] no caso do técnico, eu acho que é um pouco mais nivelado, a parte teórica e a parte prática". Observe-se que esse professor não haveria estudado tampouco lecionado em faculdades de design. Isto sugere que seu depoimento, em que apontaria carência de abordagem prática na graduação em design, teria como base relatos de outras pessoas.

De maneira análoga, a Respondente 3, outra professora, mencionou apresentar dificuldade em relacionar o ensino técnico de comunicação visual com o de graduação de design gráfico por não possuir formação nesta área. Segundo ela, "Eu não posso responder isso porque eu não fiz comunicação visual, eu não fiz design gráfico, eu sou das artes plásticas, era uma coisa completamente diferente". A mesma Respondente 3 acrescentou perceber que parcela considerável de alunos não faria faculdade: "Fazem porque precisam, querem fazer". Tal declaração sugere que, em época anterior, parte significativa de alunos de cursos técnicos de comunicação visual, logo após seu término, iria para o mercado de trabalho. Pressupõe, ainda, que o mercado de trabalho haveria deixado de valorizar o ensino técnico, seja por questão de nomenclatura ou, ainda, em decorrência do aumento do número de egressos de cursos superiores de design.

Por outro ponto de vista, a Respondente 27, uma ex-aluna do Etim, mencionando seus colegas de faculdade, relatou perceber certo comprometimento em relação ao próprio estudo. Segundo ela, "Na faculdade, você já tem noção [...] de que você vai sair e arrumar um emprego e você tem que adquirir conhecimento. [...] você tem meio que correr atrás sozinho, procurar bibliografia, referências, texto p'ra ler [...] e, com isso, adquirir repertório". Sua fala sugere que parcela expressiva de pessoas cursando uma graduação perceberia a importância de aproveitar este período para se capacitar, da melhor forma possível, para futura atuação no mercado de trabalho. Quanto a alunos de cursos técnicos, a mesma Respondente 27 informou notar diferença de aproveitamento. Para ela, "[...] o técnico também deve ter essa característica de te proporcionar essa ampliação de conhecimento. Só que, como foi junto com o ensino médio, [...] você só vai aprender o que o professor falou ali. Você não vai atrás disso depois". Este trecho de seu depoimento parece indicar que alunos do Etim, apesar de serem expostos a conteúdos relevantes da área 
de comunicação visual, seriam, aparentemente, mais imaturos do que os estudantes do ensino técnico (não vinculado ao ensino médio) para se empenhar em seus estudos. Tal diferença de dedicação parece ser, segundo essa respondente, ainda maior em relação aos discentes de cursos superiores.

Semelhante aos depoimentos dos demais docentes, o Respondente 2, também professor, relatou que no curso técnico a aula é prática e no curso superior é teórica e que o conteúdo prático do ensino superior seria o mesmo que do ensino técnico. O mesmo Respondente 2 declarou que o ensino superior deveria estar relacionado a outras questões, como iniciação científica, licenciatura e pesquisa, já que: "O 'técnico' é quem bota a mão na massa" e lamentaria o fato de o país não valorizar isto, evidenciando a disputa de mercado em que o ensino superior assumiria a prática profissional que seria do ensino técnico. Ainda, de acordo com o Respondente 2, o currículo do ensino técnico possibilitaria ao aluno disputar campos na área do ensino superior por competência e então, caso se valorizasse competência e não título, muita gente do ensino técnico seria absorvida pelo mercado.

De maneira complementar, o Respondente 4, igualmente professor, relatou que, no período em que atuou no ensino superior, as aulas que preparava para a faculdade seriam as mesmas que ministrava no curso técnico. Segundo ele: "Os alunos que não trabalhavam, iam muito mais sem saber o que fazer da vida no 'superior'. Eu não sei se a gente dá a base e, aí, ele vai p'ra faculdade com esta base e consegue interagir com o conteúdo de lá". Sua declaração sugere que o curso técnico potencialmente possibilitaria aos alunos adquirirem noção mais acertada a respeito de conteúdos e habilidades intrínsecas à área, minimizando possíveis desapontamentos. O próprio Respondente 4, como visto na seção 4.4.1.1.1, informou haver instituição de curso superior que copiara o Plano de Curso do "Técnico de Comunicação Visual" da Etec, apenas mudara o nome da disciplina, acrescentando: "[...] tem um trabalho autoral, do Centro Paula Souza, tem o laboratório de currículo. Que faculdade faz isso?". Seu depoimento sugere que o currículo do curso técnico de comunicação visual das escolas da rede Etec seria relevante; caso contrário, não se evidenciaria sua replicação em faculdade. 
Por sua vez, o Respondente 26, outro ex-aluno, relatando sua percepção a respeito do ensino técnico de comunicação visual e da graduação em arquitetura, acreditaria haver semelhanças de abordagem nos dois cursos. Para ele, "No geral, a gente tem muita experimentação na graduação, caráter experimental de várias disciplinas, de vários exercícios, é uma marca que eu sinto aqui [faculdade] e no técnico eu sentia a mesma coisa. [...] Experimental no sentido de tentativa e erro". Esta fala parece indicar que em ambos os cursos, talvez por serem áreas com foco em projetos, as experimentações seriam incentivadas. Para o mesmo Respondente 26, em termos de pesquisa, informou ser totalmente diferente. Para ele, "Os instrumentos que a gente usava de pesquisa no técnico era, na época, internet. Hoje, eu faço busca no arquivo histórico municipal, fonte primária, [...] circulo em várias bibliotecas, coisas que, no técnico, era inconcebível". Este segmento pressupõe que, em cursos técnicos, talvez em função do encurtamento do tempo para a execução de atividades e de dificuldades de deslocamento, a internet seria a alternativa mais apropriada. Sugere, ainda, que na graduação, o nível de exigência e de complexidade dos trabalhos demandariam investigações mais aprofundadas e, consequentemente, outros materiais e meios de pesquisa.

Comparando uma aula de história da arte no ensino técnico e na graduação, o mesmo Respondente 26 acreditaria que os objetivos dos cursos seriam distintos. Segundo ele, "No técnico, se olhava muito como referência, era uma aula p'ra gente saber o que aconteceu e produzir uma coisa depois. Na faculdade, é muito mais refletir sobre o objeto, [...] como esse objeto se configurou. O que que isso implica na realidade". Seu depoimento parece indicar que na graduação, além de maior aprofundamento nos conteúdos em relação aos do curso técnico, o intuito seria o de promover desenvolvimento de pensamento crítico discente.

Em síntese, os dados apurados sugerem que: os conceitos apresentados aos alunos teriam caráter introdutório; parcela considerável de alunos assimilaria mais facilmente conceitos durante o processo de desenvolvimento de projetos; a internet seria o meio de pesquisa mais utilizado por alunos; existe uma possível lacuna com respeito à metodologia de projeto em cursos técnicos; alunos egressos de cursos técnicos de comunicação visual estariam, de modo geral, mais bem preparados, tanto no âmbito de conhecimento quanto de maturidade, para acompanhar cursos 
superiores de design e de áreas afins. Quanto ao foco do ensino superior em design gráfico ser teórico enquanto o do ensino técnico ser prático, bem como de que haveria igualdade de conteúdos práticos entre o ensino superior e o técnico, tal visão seria, majoritariamente, de professores formados em artes plásticas, talvez, sem contato mais direto com a graduação em design.

\subsubsection{2}

\section{Perspectivas de respondentes associados a escolas da rede Senac-SP}

O Respondente 31, professor, como visto na seção 4.4.14.2, ao comparar o ensino técnico ao superior de design, aludiu à percebida ênfase em aspectos práticos no ensino técnico em relação a aspectos teóricos, que seriam mais característicos do ensino universitário. Segundo ele: "A graduação é mais focada em teoria. No técnico é muito mais prático. A gente esmiúça a teoria conforme for aplicando na prática. A teoria é a base, a gente indica bibliografia". Sua declaração parece indicar que, no ensino técnico, a teoria contextualizaria a prática. Além disso, os alunos seriam incentivados, por si próprios, a ampliarem seus conhecimentos teóricos. No fragmento examinado, em relação à graduação, não parece ter ficado muito claro qual seria a dimensão prática do ensino.

De modo semelhante, aspecto também citado na seção 4.4.14.2, a Respondente 29, outra professora, enfatizou o caráter prático do ensino técnico. Para ela, "Eu acho o máximo o técnico porque é muita prática. Algumas faculdades é muita teoria [...]. Na minha visão, nos dois casos, os alunos 'tão tendo, por exemplo, história da arte. [...] O curso técnico seria mais pela carga horária. Seria mais resumido". Este ponto de vista quanto ao que seria oferecido nas duas modalidades de ensino parece indicar que, por vezes, os conteúdos seriam semelhantes, porém a diferenciação ocorreria, sobretudo, no âmbito do aprofundamento em função do tempo.

Esta mesma visão foi defendida pela Respondente 30, outra professora, ao evidenciar similaridade de conteúdos do ensino técnico e do superior, bem como desigualdade de tempo para a realização de atividades: "Eu acredito que ele não fica atrás de maneira nenhuma de uma graduação superior porque, querendo ou não, esses 
elementos curriculares são os mesmos. A gente só não tem o tempo de práxis p'ra exercícios, por conta da carga horária". Ainda a mesma Respondente 30 , como citado no item 4.4.10.2, apontou o tempo como fator relevante de diferenciação: "A identidade criativa é um tempo que dá p'ra se realizar. Mas é bem menos tempo que uma graduação, então, olha a responsabilidade que a gente tem que ter enquanto docente de, em menos tempo, manter uma qualidade de convivência no grupo". Tal preocupação denota visão de que o fator tempo, percebido como mais restrito, influenciaria outras esferas, inclusive a da interação social, entre os participantes dos processos pedagógicos.

Por sua vez, a Respondente 32, outra professora, destacou, como problemática, a situação do ensino de design em algumas faculdades. De acordo com ela: "[...] as instituições p'ra se manterem vivas, principalmente as privadas, comerciais, elas aceitam tudo. [...] Tem faculdade que cobra 200 reais por mês. É só p'r'o cara 'tá ali. Como você vai incentivar o professor? E o salário?". Tais questões parecem indicar precarização do trabalho, com impacto na qualidade do ensino, sobretudo em determinadas instituições particulares e, por isso, a mesma Respondente 32 ressaltou que: "[...] o nosso ensino da graduação, p'ra mim, em relação ao técnico que eu leciono e ao Senac, 'tá pior. É pior em quatro do que em um ano e meio [em cursos técnicos]. [...] Mas eu acho que, no ensino público, não dá p'ra comparar. Obviamente é muito melhor". Esta afirmação sugere, primeiramente, percebida diferença do ensino de design em termos qualitativos em cursos superiores desta área. Pressupõe, ainda, que cursos técnicos de design, apesar de a carga horária geral ser reduzida, seriam melhores do que de parte das faculdades particulares, mas, talvez, inferiores em relação a cursos superiores de instituições públicas.

Os dados sistematizados acima sugerem que, em cursos técnicos de comunicação visual de escolas da rede Senac, a teoria contextualizaria a prática; haveria similaridade de conteúdos aos do curso superior de design gráfico, com diferenciação de aprofundamento em razão do tempo; seria percebida melhor qualidade do ensino em relação a determinadas faculdades particulares. 


\subsection{4 \\ Eventuais influências, relatadas por egressos, na escolha posterior de cursos universitários}

Os dados analisados na categoria temática apresentada nesta seção foram separados em subseções correspondentes às duas principais redes de escolas técnicas cobertas pela pesquisa: a Etec-SP e o Senac-SP.

\subsubsection{1}

\section{Perspectivas de respondentes associados a escolas da rede Etec-SP}

Em relação a eventual influência na escolha posterior de seu curso universitário, a Respondente 23, ex-aluna, informou que, a princípio, seria meio difícil de dizer, porque desde seus 14 anos queria fazer alguma coisa relacionada a desenho. Assim, iniciou o curso técnico em design de interiores, como visto na seção 4.1.2.1, e, mais tarde, perceberia maior proximidade deste curso com a área da arquitetura, decidindo ingressar no Técnico em Comunicação Visual, mas sem ter conhecimento anterior sobre o campo. Para ela, “[...] também não sabia o que era comunicação visual, mas depois, me apaixonei pela área. Aí, eu fui aprofundando. Então, de certa forma, eu acho que o técnico teve um peso muito importante p'ra eu escolher fazer a faculdade". Observe-se que, antes do curso técnico de comunicação visual, essa respondente não possuiria ideia a respeito da área. Isto sugere que os conteúdos e abordagens de seu curso técnico teriam sido percebidos como significativos a ponto de levá-la à graduação em design.

Similarmente, a Respondente 25, outra ex-aluna, reforçou o crédito do ensino técnico na definição de seu curso na graduação. De acordo com ela, "Confirmou a minha escolha do técnico. Porque eu gostei, de um modo geral, bastante do técnico. Só que eu não tinha essa noção do que era o design ainda. Isso, eu só fui ver na faculdade mesmo". Sua fala pressupõe que, apesar de o curso técnico ter contribuído para continuidade de seus estudos no âmbito superior, as características e atribuições do design parecem não ter sido devidamente tratadas no ensino técnico de comunicação visual. 
Por seu turno, o Respondente 26, também ex-aluno, como citado na seção 4.1.2.1, embora intencionasse seguir a área da arquitetura desde os 12 anos, cursaria o técnico em comunicação visual. Relatando sua experiência nesse curso, declarou ter se identificado com determinados segmentos do design gráfico. De acordo com ele, "Eu gostava do que eu fazia de design gráfico, muito da parte mais voltada p'ra editorial, p'ra produção de revista. A parte de layout e diagramação, eu gostava bastante. Então, eu faria aquilo. A parte de branding, eu não achava incrível". Esta fala sugere que esse respondente teria preferência por criação de identidade e organização de informações em publicações. Quanto à possibilidade de continuar tal estudo na graduação, informou ter se decidido durante o curso técnico. Segundo ele, "Na metade, eu já sabia que não queria seguir naquela área. [...] Mesmo eu querendo fazer muito design naquele momento, eu nunca deixei de querer fazer arquitetura". Esta declaração sugere que, apesar de os conteúdos de cursos técnicos em comunicação visual serem percebidos como significativos, a anterior afinidade desse respondente com arquitetura haveria prevalecido.

Já a Respondente 27, igualmente ex-aluna, descrevendo suas preferências pessoais descobertas durante seu curso técnico, mencionou não apreciar conteúdos de natureza operacional: "Eu não gosto muito de mexer no computador. [...] Gosto de ter essa parte manual, de desenhar, de pensar, de criar, de referências visuais. [...] Me ajudou a ver que eu não queria publicidade e, ainda, abriu outros caminhos, que foi a arquitetura". Observe-se que essa respondente não apreciaria trabalhar utilizando ferramentas digitais, e sim por meio de abordagens mais manuais; além disso, teria notado sua afinidade com a área criativa durante o curso. Isto sugere que cursos técnicos de comunicação visual poderiam auxiliar parte dos alunos a identificar possíveis afinidades com a área, favorecendo, inclusive, sua revisão de anteriores escolhas.

De modo diverso, a Respondente 28, também ex-aluna, a respeito da influência do ensino técnico em sua subsequente escolha acadêmica, informou ter sido absoluta. Segundo ela, "Foi a constatação de que eu queria muito fazer isso. [...] Quando eu entrei lá [curso técnico], eu encontrei um monte de gente que olhava p'ra papel e falava: 'nossa, que papel bonito'. As minhas loucuras passaram a fazer sentido". Esta declaração sugere que essa respondente, antes de ingressar no ensino técnico 
de comunicação visual, já apresentaria certa sensibilidade para a atuação no campo, como o mencionado apreço por determinados tipos de papel. Pressupõe, ainda, que haveria identificação com parte dos colegas, que compartilhariam gostos semelhantes, acentuando sua afinidade com a área.

Os dados comentados acima parecem indicar que o montante de respondentes egressos de cursos técnicos de comunicação visual de escolas da rede Etec-SP haveria se beneficiado do aprendizado de determinados conteúdos e abordagens inerentes à área, auxiliando-os em suas escolhas posteriores de cursos universitários. Assim, parte significativa de egressos teria dado continuidade a seus estudos na área do design enquanto parcela menor seguiu o campo da arquitetura.

\subsubsection{2}

\section{Perspectivas de respondentes associados a escolas da rede Senac-SP}

Quanto à possível influência na escolha posterior de seu curso universitário de design gráfico, a Respondente 38, ex-aluna citada, informou não possuir anterior conhecimento a respeito da área da comunicação visual, identificando-se com a mesma durante seu curso técnico. Segundo ela: "[...] o técnico abriu as portas tanto p'r'o curso de design, quanto p'ra uma coisa que eu não sabia como era, que era o trabalho em equipe p'ra um projeto de verdade. Fazer amizade com uma pessoa que quer a mesma coisa: um projeto bem feito". Esta passagem pressupõe entendimento do valor do trabalho colaborativo em área transdisciplinar como a do design. Ainda, a mesma Respondente 38 declarou considerar que o ensino técnico de comunicação visual haveria contribuído para a ampliação de seus conhecimentos: "Ter contato com a arte, com a cultura também, eu tive maior no curso técnico. [...] Eu tive certeza do que eu ia fazer depois. Antes, eu nem sabia se eu ia fazer faculdade. O curso técnico que me direcionou até p'ra isso". Esta afirmação sugere que conteúdos de cursos técnicos teriam potencial de promover ampliação de horizontes culturais, vocacionais e profissionais. Pressupõe, também, que cursos técnicos poderiam servir de instrumental para continuidade de estudos universitários. 
Ainda, relativamente à decisão por cursar graduação em design gráfico, a Respondente 37, igualmente ex-aluna, como visto na seção 4.1.2.2, mencionou que haveria ingressado no Curso Técnico em Comunicação Visual pensando em algo para o futuro: "Eu entrei com a mentalidade de achar uma coisa que eu ia fazer p'ra minha vida. Eu olhava como uma coisa muito séria. [...] Eu gostei, porque eu comecei a gostar de design. Aí, eu queria aprender mais. Então, eu tinha que ir p'ra graduação". Seu comentário sugere que cursos técnicos poderiam ajudar alunos a descobrirem possível afinidade com determinada área. Quanto ao percebido mérito do ensino técnico, a mesma Respondente 37 afirmou: "Se eu pudesse falar p'ra todas as pessoas que tão assim... 'Mesmo que você já saiba que é aquilo que você quer ou, se você não sabe, faça o ensino técnico antes de entrar na faculdade'. Me ajudou muito quando eu entrei na graduação". Tal declaração sugere que cursar um ensino técnico precedentemente ao ensino superior diminuiria a eventualidade de uma escolha equivocada.

A Respondente 36, também ex-aluna, como abordado no item 4.1.2.2, pretenderia estudar design de moda, mas optaria por cursar o Técnico em Comunicação Visual em função da bolsa de estudo adquirida. Relatando a acertada escolha e posterior influência para seguir os estudos na graduação em design gráfico, declarou: "Eu comecei a ter certeza quando eu estava no técnico. [...] Até de identificação, eu acho que hoje, eu posso dizer que eu estou mais p'r'o design gráfico ou design em geral do que só design de moda". Esta fala sugere que o curso técnico de comunicação visual, embora não sendo a primeira opção, seria bem-sucedido. Pressupõe, ainda, que conteúdos trabalhados neste curso contribuíram, de algum modo, para sua decisão de continuar os estudos universitários na mesma área.

Com base em depoimentos de egressos, o curso técnico de comunicação visual de escolas da rede Senac teria possibilitado a seus alunos: o conhecimento a respeito da área, sobretudo em termos práticos; perceber o valor de se trabalhar em equipe; escolher com mais propriedade a futura área profissional, bem como ampliar seus horizontes culturais. Destaque-se que a totalidade dos respondentes haveria dado continuidade a seus estudos na graduação em design gráfico na mesma instituição. 


\subsection{5}

\section{Antevisões de propostas pedagógicas verbalizadas como ideais}

Quanto a um especulado modelo de curso ideal, o Respondente 31, professor, informou não achar necessária nenhuma mudança, ao declarar: "O curso atual acho ideal do jeito que foi estruturado". Já a Respondente 32, outra professora, destacou como importante a colaboração de pessoas ativamente relacionadas ao ensino.

Segundo ela, "[...] chamaria professor, quem já foi professor, aluno, ex-aluno, quem sabe o que 'tá falando p'ra elaborar. E não pedagogos, psicólogos e quem monta material fora. [...] Colocaria muita coisa de processos manuais com os tecnológicos". Este relato sugere crença de que alguns especialistas mais teóricos, normalmente responsáveis por elaborar propostas pedagógicas, não seriam os mais indicados para a tarefa de planejar cursos técnicos de design gráfico - supostamente mais aperfeiçoados -, por não vivenciarem diretamente o ensino na área do design; além disso, esse respondente valorizaria abordagens mais sensoriais, empíricas, do tipo "mão na massa".

Ainda, de acordo com a mesma Respondente 32, haveria mérito em promover flexibilização do percurso formativo do aluno. Para ela, "[...] se eu tivesse essa possibilidade, e eu sei que é o MEC que rege isso, eu também incluiria fazer as competências de acordo com o que o aluno quer fazer, com o tempo que quer fazer. Cada um construiria sua própria formação". Isto parece indicar preferência por propostas pedagógicas menos rígidas, que possibilitem maior autonomia dos alunos. Quanto aos objetivos mais amplos do ensino, a própria Respondente 32 sugeriu que: "[...] tem que continuar com coisas reais, envolvimento com a sociedade. Mas eu bateria muito em devolver essa parte de educação p'ra sociedade de alguma forma. Todo o projeto tem que ter uma proposta de como você vai ensinar alguém também". Esta afirmação parece alinhada com o entendimento da relevância de multiplicar-se conhecimento por meio de projetos que incluiriam a dimensão pedagógica.

A Respondente 30, professora já citada, também apontou valor em focar o ensino na dimensão mais empírica dos materiais: "Eu ia fazer uma Bauhaus e uma Escola de Ulm de novo. Seria algo a partir dos materiais. O trabalho inicial vocacional p'r'as linhas criativas. [...] você começa a se deleitar por algo que seja mais próximo 
da sua identidade. Depois vem os desafios". Seu relato parece indicar intenção de promover, de início, uma sensibilização a partir de abordagens mais empíricas e sensoriais com sentido, sobretudo, indutivo (mais em linha com a Bauhaus, em realidade, do que, propriamente, com a HfG Ulm). A própria Respondente 30 , como visto na seção 4.5.2.2, destacou a importância de exercitar, nos alunos, o repertório criativo em âmbito essencialmente analógico, do instrumento em contato direto com o suporte. De acordo com ela, "A parte digital teria que abandonar, um pouco, e ir p'r'o papel, p'r'o chão, p'r'o grafite, p'ra parede. Começar pensando no primitivismo, processo clássico, ordem, depois, neste momento das trevas, tudo trazendo p'ra soluções que vão atender às mídias de hoje". Este trecho sugere propósito de proporcionar aos alunos várias vivências criativas, com base em movimentos artísticos e técnicas diversas, trazendo-os, ao mesmo tempo, para o universo das criações contemporâneas. Além disto, aponta a preferência dessa educadora por métodos e processos de projeto que evidenciariam a forma de representação, seja manual, impressa ou digital.

Ainda, em relação a este processo propedêutico de formação de repertório e referências, a mesma Respondente 30 acrescentou: “[...] vai p'r'o funcional, dentro de casa, simples. Já é século XX. [...] Depois que você pegou esse repertório todo de criação, mais fluídico, mais livre, que vai se identificando, começam os projetos pessoais. Depois vem o mercado. Começa o desafio de fora". Esta visão parece valorizar abordagens de contextualização prévia, até com caráter histórico, com o propósito de induzir o processo criativo mais específico da área do design, visando, em um primeiro momento, formação de repertório para, somente depois, expô-los a demandas atuais do mercado. Tal abordagem pedagógica parece refletir, em certa medida, a característica dos cursos técnicos de comunicação visual do Senac-SP, que dão ênfase neste aspecto de constituição prévia de repertório para subsidiar atividades de projeto.

Os dados examinados acima sugerem preferência por propostas pedagógicas menos rígidas, que possibilitariam maior autonomia dos alunos, com foco na dimensão mais empírica dos materiais com sentido, sobretudo, indutivo. Pressupõem, ainda, atenção em multiplicar-se conhecimento por meio de projetos que incluiriam a dimensão pedagógica, além de formação de repertório criativo. 


\subsection{6}

\section{Matizes político-ideológicos eventualmente identificáveis em práticas pedagógicas pesquisadas}

Os dados analisados na categoria temática apresentada nesta seção foram separados em subseções correspondentes às duas principais redes de escolas técnicas cobertas pela pesquisa: a Etec-SP e o Senac-SP.

\subsubsection{1}

\section{Perspectivas de respondentes associados a escolas da rede Etec-SP}

Quanto a matizes político-ideológicos eventualmente identificáveis em práticas pedagógicas pesquisadas, o Respondente 2, professor, como citado na seção 4.2.1.1 e 4.4.6.1, mencionou o motivo que o levara ao magistério. De acordo com ele: "Eu fiz CV aqui na escola, mas eu vi que era isso que eu queria, interagir com as pessoas p'ra que elas se descobrissem e não fossem os copistas da vida, mas que assumissem autonomia das suas ações, então é o que eu mais trabalho com eles". Este trecho de seu depoimento sugere elementos mais difusamente associados a uma componente ideológica, isto é, em um sentido mais amplo seria uma forma de ideologia emancipatória, não apresentando sentido político-partidário. Deste modo, parece estar procurando conferir poder a seus alunos, o que os incentivaria a se posicionarem perante seus projetos e suas vidas.

Por sua vez, o Respondente 4, também professor, a respeito de seu trabalho profissional, como visto na seção 4.2.3.1, informou que: "Minha linha de trabalho é mais design alternativo mesmo, a contracultura, culturas juvenis. Como que o jovem interage com a cultura, o jovem com a cidade, como ocorre essas interações, como o jovem trabalha hoje. As negociações que ocorrem" (grifo da pesquisadora). Os trechos grifados sugerem presença de componentes, de certo modo, ideológicos na fala do referido respondente, identificando-o com uma visão presumivelmente mais crítica da sociedade de consumo, buscando incentivar seus alunos a refletir segundo tal orientação menos conformada a uma visão de mundo mais burguesa. 
Os dados apurados parecem indicar presença de elementos difusos de uma ideologia emancipatória e de crítica da sociedade de consumo, não apresentando sentido político-partidário em práticas pedagógicas do ensino de comunicação visual das escolas da rede Etec-SP.

\subsubsection{2}

\section{Perspectivas de respondentes associados a escolas da rede Senac-SP}

Em relação a matizes político-ideológicos eventualmente identificáveis em práticas pedagógicas pesquisadas, a Respondente 30 , professora, como citado na seção 4.4.13.2, mencionou que o Senac-SP orientaria duas propostas de projeto. Uma abordagem corresponderia à apresentação de um layout arrojado, um trabalho simbólico, uma ilustração bem definida; a outra abordagem, segundo ela, "[...] tem um outro viés que é sempre o olhar para um design voltado p'r'o social. Que seria, por exemplo, cartazes alusivos p'ra que as pessoas tenham uma mensagem de melhorar sua qualidade de vida. [...] É o design voltado p'ra melhoria do mundo". Sua fala sugere presença de elementos claramente ideológicos, percebidos como até bastante positivos, nos exercícios pedagógicos apresentados aos alunos. Observe-se, também, que este caráter ideológico não chega ao ponto de ter natureza político-partidária.

De maneira semelhante, como visto na seção 4.7.5, a Respondente 32, outra professora, em alusão a uma proposta pedagógica ideal, mencionou como objetivo mais amplo do ensino: "[...] tem que continuar com coisas reais, envolvimento com a sociedade. Mas eu bateria muito em devolver essa parte de educação p'ra sociedade de alguma forma. Todo o projeto tem que ter uma proposta de como você vai ensinar alguém também". Sua declaração sugere valorização de projetos voltados para questões de ensino e de propagação de conhecimento para classes menos favorecidas da sociedade.

Com base nestes depoimentos, parece que haveria certo grau de componentes ideológicos em práticas pedagógicas no ensino técnico de comunicação visual das escolas da rede Senac, mas não configurando caráter político-partidário. 


\section{5}

Recapitulação de alguns principais resultados, conclusões e sugestões de pesquisas complementares

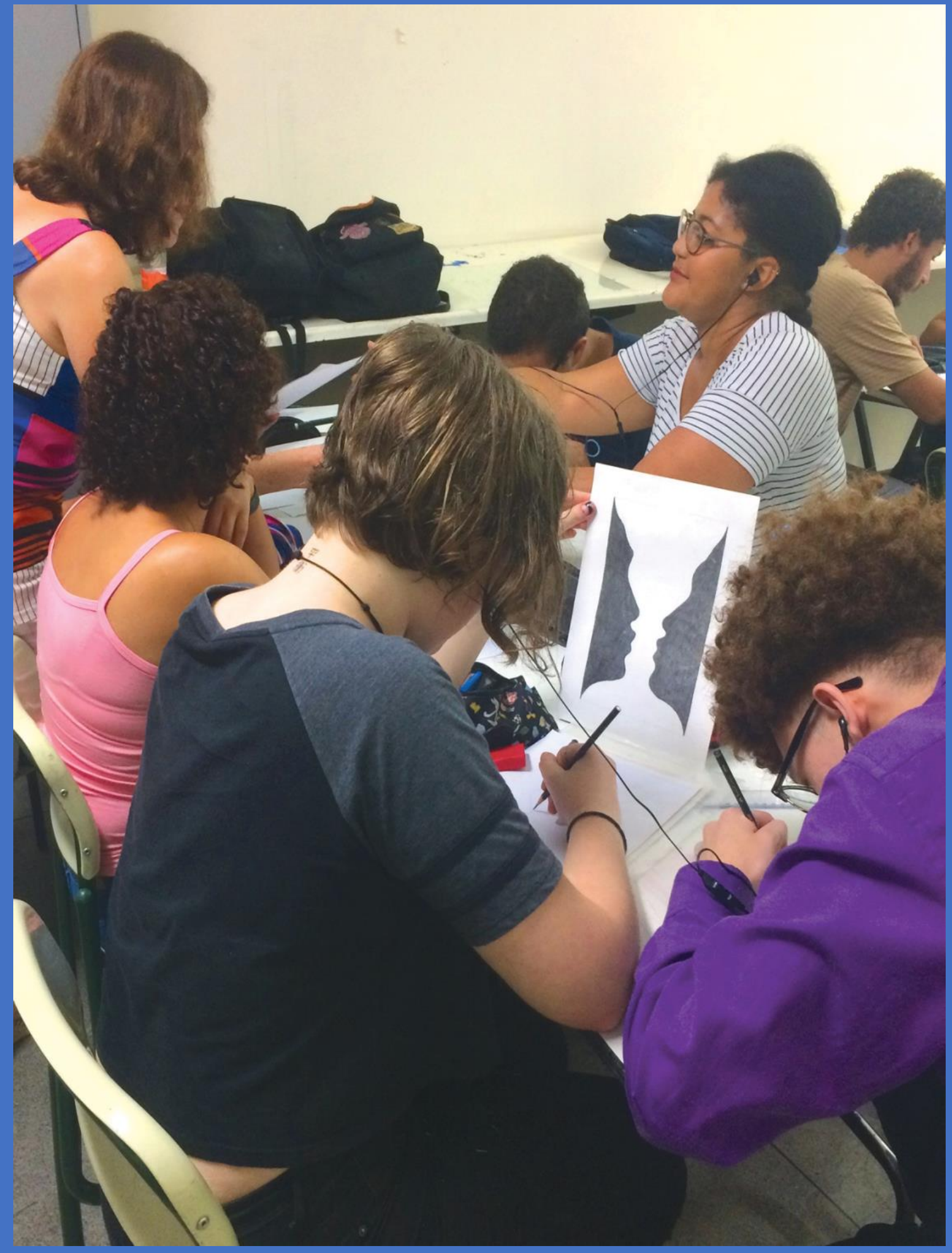




\section{5}

Recapitulação de alguns principais resultados, conclusões e sugestões de pesquisas complementares

\section{0}

\section{Considerações iniciais a respeito do capítulo 5}

Neste capítulo, apresenta-se uma recapitulação do trabalho, sumariando alguns principais resultados expostos no capítulo 4. Busca-se, aqui, elaborar uma análise mais abrangente, já apontando para a seção de conclusões. Por fim, expõem-se sugestões de pesquisas complementares.

\section{1}

\section{Recapitulação de alguns principais resultados}

Esta investigação sobre o ensino técnico de design gráfico na cidade de São Paulo possibilitou ouvir depoimentos de coordenadores, professores, alunos e ex-alunos, sobretudo de duas das dez escolas que oferecem ensino técnico de design gráfico na cidade de São Paulo em 2018 e 2019: uma escola da rede Etec-SP e outra da rede Senac-SP. Esta pesquisa objetivou, assim, conhecer o interior das instituições, suas estruturas materiais e físicas, realizar observações de aulas, analisar trabalhos de alunos, materiais didáticos e de apoio, entre outras formas de se enfronhar na realidade investigativa.

Ao se examinar, então, as análises desenvolvidas no capítulo de resultados, chega-se à compreensão de que haveria expressiva diversidade no perfil de alunos de cursos técnicos. Nos cursos da modalidade Etim, parte significativa dos alunos escolheria fazer o curso técnico por influência familiar. Já a escolha por comunicação visual aconteceria, especialmente, por influência de amigos e em razão da afinidade dos alunos com o desenho, pintura ou em vista do desejo de aprender a utilizar aplicativos gráficos ou, ainda, por eles considerar que seria um curso mais fácil, por envolver competências de desenho. 
Apesar de parte dos alunos da modalidade não integrada ao ensino médio (chamada de "modular") do período diurno ainda estar cursando ou tendo finalizado há pouco tempo o ensino médio, parece que os alunos ingressam mais conscientemente em comparação com os alunos da modalidade Etim. De toda maneira, estes alunos seriam um pouco mais velhos do que aqueles. A maioria desses alunos não possuiria muita informação sobre o mercado de trabalho, nem vivência direta e, embora os cursos técnicos se proponham a prepará-los para o mercado de trabalho, não parecem possuir conhecimento muito exato do que seria a atividade da comunicação visual. Os alunos do curso "modular" noturno, no entanto, apresentariam perfil mais variado: parcela deles já vivenciou alguma atividade profissional e procuraria o curso técnico para se especializar nesta área ou tencionaria mudar de carreira.

Tendo em vista que, conforme os relatos, os egressos de cursos técnicos de comunicação visual sairiam sem entendimento claro do que seja a área, isto talvez se deva ao fato de estes cursos, sobretudo nas Etecs, não abrangerem apenas conteúdos relacionados à comunicação visual, parecendo abarcar, neste sentido, tudo o que apresentaria certa "veia criativa", percebendo-se, então, elementos das artes plásticas e da publicidade.

Quanto ao ambiente físico das aulas e laboratórios, em geral, as salas seriam adequadamente iluminadas, havendo espaço suficiente para desenvolvimento de atividades em mesas dispostas umas em frente às outras, o que facilitaria a troca de ideias, uma vez que muitos trabalhos mais complexos - como, por exemplo, manuais de identidade visual ou projetos de revistas - seriam realizados em grupo.

Já com respeito a técnicas e ferramentas ensinadas aos alunos, percebe-se ênfase no aprendizado de aplicativos gráficos para execução de projetos no computador. Vários laboratórios de informática na rede Etec-SP são equipados com computadores Macintosh, havendo exclusividade em seu uso para alunos dos cursos de comunicação visual e eventual compartilhamento em função do estágio do curso. Na rede Senac-SP, existiriam laboratórios de PC ou de Mac, dependendo da unidade escolar. Haveria, também, nas Etecs, oficinas destinadas a atividades mais especialmente relacionadas às artes plásticas (desenho de observação, 
pintura, execução de círculo cromático etc.). Encontram-se, ainda, oficinas multiuso na Etec-SP (e não no Senac-SP) para exercício de composição e impressão serigráfica. As escolas, ao exporem os alunos a ambientes e materiais menos convencionais com abordagens também alternativas, buscariam estimular habilidades sensoriais, motoras, cognitivas e sociais.

De modo geral, os alunos seriam expostos a conteúdos teóricos previa ou concomitantemente à parte prática. Nota-se certa resistência a abordagens teóricas por parte dos alunos de cursos técnicos, sendo considerado insuficiente o padrão médio de leitura. Estratégias pedagógicas conhecidas como "passo a passo" seriam mais utilizadas, configurando-se, sobretudo, em trabalho de aprendizado de programas de aplicativos gráficos, com menos ênfase em projeto. Em relação a isto, observou-se presença de conteúdos de projeto de design gráfico na criação de revistas e em TCCs. Identificou-se, também, que cursos técnicos de comunicação visual, nas duas redes estudadas, seriam bastante centrados em projetos de programas em identidade visual. Os alunos seriam apresentados a bastantes conteúdos e exercícios envolvendo logotipos e suas aplicações, explorando o que funcionaria e o que não funcionaria tão bem. Quanto a isto, a teoria seria mais especialmente vinculada ao sentido crítico. As abordagens teóricas predominantes, nas duas redes de ensino, tendem a abordar, em especial, aspectos de produção gráfica.

Como várias vezes reportado ao longo do capítulo de resultados, é notável a presença de categorias conceituais mais relacionadas ao universo das artes plásticas no curso técnico de comunicação visual das Etecs-SP, possivelmente em razão da majoritária formação dos respondentes nesta área. Apesar disto, é perceptível a preocupação de parte dos docentes em adaptar conteúdos das artes plásticas para o campo do design, bem como sua atenção quanto à inserção dos jovens no âmbito cultural, social e profissional. Como igualmente comentado no capítulo de resultados, o corpo docente do Senac-SP é formado por número significativo de profissionais com prática de mercado, especialmente da área do design, da publicidade/propaganda e do marketing. Neste contexto, percebe-se que muitos dos conteúdos apresentados aos alunos se relacionariam à área da publicidade e do marketing. $O$ fato de que parcela dos professores formados em outras áreas atuaria no mercado de trabalho do design espelha alinhamento 
ao programa pedagógico mais geral de escolas da rede Senac-SP, que valorizaria inclusão de conteúdos mais estritamente vinculados à prática profissional.

Outro aspecto que se destaca refere-se à presença de elementos difusos de uma ideologia emancipatória e de crítica da sociedade de consumo em práticas pedagógicas do ensino de comunicação visual das escolas da rede Etec. Observou-se, também, presença de elementos claramente ideológicos, percebidos como até bastante positivos, nos exercícios pedagógicos apresentados aos alunos da rede de escolas Senac. Nos dois casos, tal caráter ideológico não chega ao ponto de manifestar natureza político-partidária.

Como apontado no capítulo de resultados, os professores de cursos técnicos tendem a considerar que a parte prática do ensino superior corresponderia ao do ensino técnico. Muitos pressupõem que o mercado de trabalho não valorizaria o diploma dos cursos técnicos, mas o de cursos superiores. De acordo com eles, as escolas técnicas tendem a ser percebidas como meio de os alunos entrarem em contato com a comunicação visual, descobrindo uma possível afinidade com a área e se eles desejam seguir o curso superior nesta área ou em áreas afins.

Como relatado por alguns professores, em consonância com os objetivos dos cursos técnicos de comunicação visual em São Paulo, uma das propostas desses cursos técnicos seria o de proporcionar vivências similares às que os alunos deverão encontrar no mercado de trabalho, capacitando-os a funcionarem em equipe com pessoas de diferentes especialidades. Já os objetivos dos alunos variariam tanto em termos do desejo de muitos de mudar de área, de descobrir possível afinidade com a comunicação visual quanto o de ampliar o conhecimento em áreas afins à de suas formações originais, proporcionando melhor adaptação profissional. Parece, então, haver valorização do contexto de trabalho norteando o desenvolvimento de projetos em sala de aula.

Além disto, o método de projeto em design exercitado com alunos pressuporia abordagem, em geral, mais indutiva, mais espontânea e menos comprometida com uma disciplina de projeto, que parte do geral para o particular, como tende a ser ensinada em cursos superiores de design. A ausência de exposição mais sistemática 
de metodologia de projeto no âmbito dos cursos técnicos talvez se explique pela escassez de professores especificamente formados em design atuando na área.

Como visto, percebe-se atenção em expor os alunos a diversificados conteúdos e procedimentos metodológicos para a geração de ideias. Convém ressaltar o enfoque observado no ato de desenhar em processos de geração de alternativas, porém desconsiderando-se as demais etapas do método clássico de projeto. Outra questão relevante seria a preocupação em se identificar o público específico ao qual se destinaria o projeto, não havendo, entretanto, referência explícita e técnica à figura de usuários dos projetos desenvolvidos em classe, o que corrobora percepção de maior aproximação de abordagens mais especialmente relacionadas à área da propaganda do que, propriamente, à do design, em virtude da ênfase na chamada definição do público-alvo.

Como foi colocado, o termo comunicação visual para parte dos alunos seria interpretado como algo que se comunicaria por meio do sentido da visão.

Outro ponto fundamental é a percepção de que as atividades de comunicação visual e do design gráfico seriam distintas. Isto talvez se deva ao fato de que o termo comunicação visual sugeriria qualquer manifestação visual, e não necessariamente voltado a projetos gráficos. Parece conveniente dizer que o próprio nome deste curso técnico estaria contribuindo, em certos casos, para uma interpretação vaga e nem sempre acertada de sua proposta, que seria a de ensinar os fundamentos e, sobretudo, a prática do design gráfico. 


\section{2}

\section{Conclusões}

A análise das visões das diversas fontes de informações utilizadas foi apresentada, então, nos subproblemas: 1 (universos de seus alunos), 2 (perfil de seus professores), 3 (estruturas materiais e físicas disponíveis), 4 (abordagens pedagógicas praticadas), 5 (elementos de metodologia de projeto de design exercitados com os alunos), 6 (linguagens visuais características de trabalhos de alunos) e 7 (em termos de questões ainda mais gerais, intrínsecas à natureza do ensino técnico de design). Deste modo, completou-se o quadro de análise da pesquisa, possibilitando um afastamento para entender o contexto geral e fazer pareceres mais gerais.

Além da riqueza de dados adquiridos por meio de entrevistas com coordenadores, professores e alunos, consideraram-se muito informativos os depoimentos de ex-alunos, uma vez que eles vivenciaram o curso técnico de comunicação visual. Aqueles que cursaram, ou estão cursando graduação em design (ou em campos próximos) mostraram-se bem posicionados para perceber se o conteúdo, propostas e atividades desenvolvidas no ensino técnico haveria contribuído, de alguma maneira, para melhores desempenhos no ensino superior.

Quanto à ênfase de cursos técnicos de comunicação visual em encorajar os alunos a previamente identificar o "público-alvo" do projeto a ser desenvolvido, não parece haver um direcionamento para as necessidades dos usuários, pois estariam trabalhando com estereótipos socioeconômicos culturais, e não olhando para as situações de uso e para as necessidades específicas que demandem o projeto. Isto parece interessar, especialmente, do ponto de vista da linguagem visual dos trabalhos.

Em relação aos exercícios de projeto, notam-se, de modo generalizado, lacunas metodológicas e conceituais relativamente acentuadas na formação do ensino técnico, o que parece decorrência do recrutamento mais frequente de professores sem formação específica em design, ainda que alguns deles atuem, mesmo que perifericamente, no mercado profissional. 
De modo geral, parece ocorrer esta forma de prevalência de elementos das artes plásticas no ensino técnico de design gráfico, de certo modo descaracterizando a identidade própria do design, atividade especificamente baseada em projeto, implicando necessidades de usuários em situações de uso e em produção seriada. Por outro lado, as escolas técnicas, ao estimular habilidades sensoriais, motoras e cognitivas em propostas, abordagens, instruções e exercícios mais associados às artes plásticas, estariam promovendo, em algum grau, ampliação do campo vocacional e profissional de seus alunos, estimulando-os, desta forma, a considerar outros campos adjacentes à especificidade do design.

Em retrospecto, após análise mais abrangente dos dados apurados, resta, também, muito evidente a dimensão da grandeza, idealismo e empenho pessoal sincero da grande maioria dos docentes das escolas técnicas de design gráfico na cidade de São Paulo, no sentido de buscar contribuir para alargamento das perspectivas vocacionais e da visão de mundo de seus alunos, oriundos, em geral, de famílias humildes, a fim de Ihes proporcionar, potencialmente, mais chances de realização profissional e melhores condições de vida.

Ao trabalho anônimo, idealista e competente destes grandes professores, muitos dos quais colaboraram de braços abertos e sem restrições com os trabalhos de campo desta investigação, seus resultados finais estão sendo oferecidos. 


\section{3}

\section{Sugestões de pesquisas complementares}

O tema estudado, ensino técnico de design gráfico na cidade de São Paulo, por sua abrangência e importância, apresenta várias possibilidades de continuidade e de aprofundamento, tais como sugeridas a seguir.

Os aspectos investigados neste estudo qualitativo, principalmente os que deram origem às categorias das análises do levantamento de campo, poderiam ser utilizados para pesquisas com abordagem quantitativa. Tais estudos, ao serem realizados com número maior de participantes, possibilitariam confirmação de aspectos importantes, buscando tornar ainda mais conhecidas questões relevantes do ensino técnico de design gráfico.

Este estudo poderia ser replicado com outra amostra de participantes, o que permitiria verificar aspectos convergentes e divergentes com relação aos apresentados nesta pesquisa.

Também, uma pesquisa com mesmo perfil de público participante poderia ser empreendida em diferentes regiões do país, proporcionando identificação de semelhanças e diferenças como as apontadas neste estudo.

Outra investigação poderia, ainda, ser conduzida em escolas técnicas de comunicação visual, buscando aprofundar questões de linguagem, o que facilitaria a compreensão de como tal aspecto seria abordado nesta modalidade de ensino.

Finalmente, outro estudo poderia ser realizado com os mesmos alunos participantes da presente pesquisa, mas já estando em cursos superiores de design ou em áreas próximas, propiciando um entendimento mais claro das possíveis contribuições do curso técnico de comunicação visual para seu desempenho na faculdade. 
6

Referências

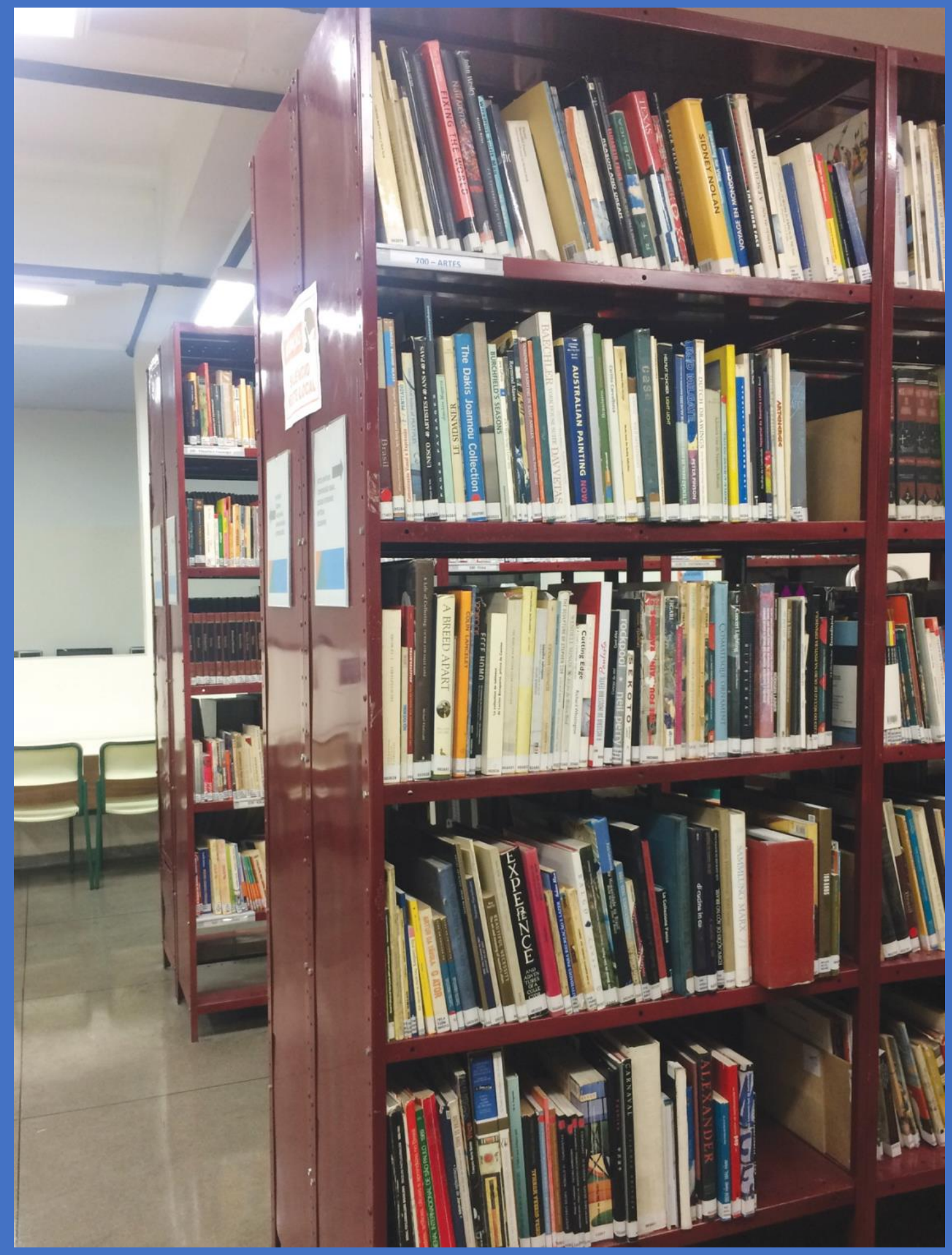


Referências $^{16}$

6.1

Bibliografia

\subsection{1}

\section{Bibliografia citada}

BARBOSA, Ana Mae. Redesenhando o desenho: educadores, política e história. São Paulo: Cortez, 2015.

BAUER, Martin W.; GASKELL, George. Pesquisa qualitativa com texto, imagem e som: um manual prático. 2a ed. Petrópolis: Vozes, 2003.

BONSIEPE, Gui. Design, cultura e sociedade. São Paulo: Blucher, 2011.

BONSIEPE, Gui. Do material ao digital. São Paulo: Blucher, 2015.

BRASIL. Lei n ${ }^{\circ} 9.394$ de 20 de dezembro de 1996. Sanciona as Diretrizes e Bases da Educação Nacional. 1996.

BRASIL. Parecer CNE/CEB 17 de 3 de dezembro de 1997. Define as Diretrizes Operacionais para a oferta da Educação Profissional em nível nacional. 1997.

CARDOSO, Rafael. Design para um mundo complexo. São Paulo: Cosac Naif, 2013.

DESAULNIERS, Julieta Beatriz Ramos. Formação, ou qualificação, ou competência. Revista Veritas, Porto Alegre, v. 38, p. 95-103, EdiPucRS, 1993.

FORMIGA, Simone. Comunicação visual. In: COELHO, Luiz Antônio Luzio (Org.). Conceitos-chave em design. Rio de Janeiro: Ed. PUC-Rio, 2011.

${ }^{16}$ De acordo com a Associação Brasileira de Normas Técnicas. NBR 6023. 
FREIRE, Paulo. Pedagogia da esperança: um reencontro com a pedagogia do oprimido. Rio de Janeiro: Paz e terra, 2002.

GOMES FILHO, João. Gestalt do objeto: sistema de leitura visual da forma. 9a ed. São Paulo: Escrituras, 2009.

KRAFT, Ulrich. Esgotamento total. Revista Viver Mente e Cérebro, n. 161, p. 60-67, jun. 2006.

LEON, Ethel. IAC: primeira escola de design do Brasil. São Paulo: Blucher, 2014.

MORAES, Dijon de. Análise do design brasileiro: entre mimese e mestiçagem.

São Paulo: Blucher, 2006.

NIEMEYER, Lucy. Design no Brasil: origens e instalação. 4a ed. Rio de Janeiro: 2AB, 2007.

PACHECO, Eliezer Moreira; MORIGI, Valter (Org.). Ensino técnico, formação profissional e cidadania: a revolução da educação profissional e tecnológica no Brasil. Porto Alegre: Penso, 2012.

SQUEFF, Letícia. O Brasil nas letras de um pintor: Manuel de Araújo Porto Alegre (1806-1879). Campinas: Editora da Unicamp, 2004.

\subsection{2}

\section{Bibliografia citada em suporte eletrônico}

ADG Brasil. Disponível em: <http://www.adg.org.br/institucional/apresentação>. Acesso em: 20 jun. 2016.

BARBOSA, Rui. O desenho e a arte industrial. 1882. Disponível em: $<$ <ttp://www.casaruibarbosa.gov.br/dados/DOC/artigos/rui_barbosa/FCRB_RuiBarbo sa_ODesenho_e_a_Artelndustrial.pdf>. Acesso em: 23 ago. 2018. 
BIELINSKI, Alba Carneiro. Liceu de Artes e Ofícios do Rio de Janeiro dos pressupostos aos reflexos de sua criação - de 1856 a 1900. 2003. 150 p. Dissertação (Mestrado em História e Crítica da Arte). Escola de Belas Artes da UFRJ). Disponível em: <https://pantheon.ufrj.br/bitstream/11422/5444/1/719053.pdf>. Acesso em: 10 fev. 2019.

CARDOSO, Rafael. A Academia Imperial de Belas Artes e o Ensino Técnico. 19\&20. Rio de Janeiro, v. 3, n. 1, 2008. Disponível em: <http://www.dezenovevinte.net/ ensino_artistico/rc_ebatecnico.htm>. Acesso em: 10 out. 2018.

CARVALHO, Ana Paula Coelho de. 0 ensino paulistano de design: a formação das escolas pioneiras. 2012, 330 p. Dissertação (Mestrado na área de concentração: Design e Arquitetura) - FAU USP, São Paulo, 2012. Disponível em: $<$ https://www.teses.usp.br/teses/disponiveis/16/16134/tde-18062012-144626/ptbr.php>. Acesso em: 5 jun. 2016.

CARVALHO, Maria Lucia Mendes de. Patrimônio cultural da química e da dietética no centro de história da Escola Técnica Estadual Carlos de Campos (SP): Catálogo da pesquisa sobre arquitetura escolar, artefatos e suas possibilidades de musealização. São Paulo, Centro Paula Souza, 2017. Disponível em: $<$ http://www.memorias.cpscetec.com.br/publicacoes/arquivos/CatalogoPCQDCMCA CA.pdf>. Acesso em: $21 \mathrm{de} \mathrm{fev.} 2020$.

CLAUDINO, Jane Carla. Formação de professores para a educação técnica de nível médio: análise do programa especial de formação pedagógica da UTFPR. 2011. 142 f. Dissertação (Mestrado em Tecnologia) - Universidade Tecnológica Federal do Paraná, Curitiba, 2011. Disponível em: <http://repositorio.utfpr.edu.br/jspui/handle/1/706>. Acesso em: 10 abr. 2016.

COSTA, Renato da Cunha Tardin. Inserção de atividades de design no ensino fundamental: um estudo de caso da disciplina comunicação visual na escola Edem no Rio de Janeiro. 2013, 100 p. Dissertação (Mestrado em Design) - Setor de Artes, Comunicação e Design da Universidade Federal do Paraná, Curitiba, 2013. Disponível em: <http://www.um.pro.br/prod/_pdf/001402.pdf>. Acesso em: 18 abr. 2016. 
COSTIN, Claudia. Ensino técnico e profissional no Brasil. O Estado de S. Paulo, São Paulo, 20 dez. 2016. Disponível em: <http://opiniao.estadao.com.br/noticias/ geral,ensino-tecnico-e-profissional-no-brasil,10000003243>. Acesso em: 14 jul. 2017.

DIAS, Dora Souza. 0 ensino de comunicação visual na FAU USP: história, implementação e características. 2015, 177 f. Dissertação (Mestrado na área de concentração: Design e Arquitetura) - FAU USP, São Paulo, 2015. Disponível em: $<$ <ttps://teses.usp.br/teses/disponiveis/16/16134/tde-07032016-180008/pt-br.php>. Acesso em: 13 maio 2016.

EDUCALINGO. Ensino técnico. Disponível em: <https://educalingo.com/pt/dicpt/técnico>. Acesso em: 29 jun. 2018.

FERRETTI, Celso João. As escolas técnicas se salvaram. Difusão de ideias, dez. 2006. Disponível em:

$<$ http://www.fcc.org.br/conteudosespeciais/difusaoideias/pdf/entrevista_escolas_tecn icas.pdf>. Acesso em: 12 jun. 2016.

FERRETTI, Celso João. Formação profissional e reforma do ensino técnico no Brasil: anos 90. Educação e sociedade, Campinas, v. 18, n. 59, ago. 1997. Disponível em: <http://dx.doi.org/10.1590/S0101-73301997000200002>. Acesso em: 13 jun. 2016.

FONTOURA, Antônio Martiniano. EdaDe: a educação de crianças e jovens através do design. 2002. 337 p. Tese (Doutorado em Engenharia) - Departamento de Engenharia de Produção e Sistema, Universidade Federal de Santa Catarina, Florianópolis, 2002. Disponível em:

<http://repositorio.ufsc.br/xmlui/handle/123456789/82554>. Acesso em: 5 abr. 2016.

LYCÊO DE ARTES E OFFICIOS DO RIO DE JANEIRO. Regulamento e regimento. Rio de Janeiro: Industria Nacional, 1871.

MINISTÉRIO DA EDUCAÇÃO. Educação profissional: referências curriculares nacionais da educação profissional de nível técnico. Área profissional: design. Brasília, 2000. Disponível em:

<http://portal.mec.gov.br/setec/arquivos/pdf/design_ref.pdfs. Acesso em: 8 set. 2016. 
MINISTÉRIO DA EDUCAÇÃO. Educação Profissional Legislação Básica, 2001. Disponível em: <http://portal. mec.gov.br/setec/arquivos/pdf/LegisBasica.pdfs. Acesso em: 25 jun. 2017.

MURASSE, Celina Midori. A educação para a ordem e o progresso do Brasil: o Liceu de Artes e Oficios do Rio de Janeiro (1856-1888). 2001. 184 p. Tese (Doutorado em Educação) - Universidade Estadual de Campinas, Faculdade de Educação, Campinas, SP. Disponível em: <http://www.repositorio.unicamp.br/handle/ REPOSIP/252132>. Acesso em: 12 fev. 2019.

MUSTO, Fernanda Maria Fornaziéri. Capital cultural e habitus em professores de educação profissional de nível técnico influenciando o ato educativo. 2008. 103 f. Dissertação (Mestrado em educação escolar) - Unesp, Faculdade de Ciências e Letras, Araraquara, 2008. Disponível em:

$<$ https://repositorio.unesp.br/handle/11449/90310>. Acesso em: 30 jun. 2016.

SCACCHETTI, Fabio Alexandre Pereira. Motivação e uso de estratégias de aprendizagem no ensino técnico profissional. 2013, 117 f. Dissertação (Mestrado em Educação) - Universidade Estadual de Londrina, Centro de Educação, Comunicação e Artes, Londrina, 2013. Disponível em: $<$ http://www.uel.br/pos/mestredu/images/stories/downloads/dissertacoes/2013/2013_ -_SCACCHETTI_Alexandre_Pereira.pdf>. Acesso em: 30 jun. 2016.

STEPHAN, Auresnede Pires; BRAGA, Marcos da Costa. A comunicação visual institucional do ladê no período de 1959 a 1987. Blucher Design Proceedings, v. 9, n. 2. São Paulo: Blucher, 2016. p. 229-240.

VIGNELLI, Massimo. The Vignelli canon. 2009. Disponível em: <https://s3-us-west2.amazonaws.com/rationale-design.com/resources/vignelli-canon/Vignelli++Canon.pdf>. Acesso em: 7 jan. 2020.

VILLAS-BOAS, André. Sobre análise gráfica, ou algumas estratégias didáticas para a difusão de um design crítico. Arcos Design, Rio de Janeiro, v. 5, p. 2-17, 2009. Disponível em: <https://edisciplinas.usp.br/pluginfile.php/4616123/mod_resource/content/1/VILLASBOAS\%202009\%20an\%C3\%A1lise\%20grafica.pdf>. Acesso em: 15 set. 2018. 


\subsection{3}

\section{Bibliografia complementar}

BRAGA, Marcos da Costa. ABDI e APDINS - RJ: história das associações pioneiras de design do Brasil. São Paulo: Blucher, 2016.

BRAGA, Marcos da Costa. (Org.). O papel social do design gráfico: histórias, conceitos e atuação profissional. São Paulo: Senac, 2011.

COUTO, Rita Maria de Souza. Escritos sobre ensino de design no Brasil. Rio de Janeiro, 2008.

COUTO, Rita Maria de Souza; FARBIARZ, Jackeline Lima; NOVAES, Luiza.

Gustavo Amarante Bomfim: uma coletânea. Rio de Janeiro: Rio Book's, 2014.

CRESWELL, John. W. Investigação qualitativa e projeto de pesquisa:

escolhendo entre cinco abordagens. 3a ed. Porto Alegre: Penso, 2014.

DONDIS, Donis A. Sintaxe da linguagem visual. 2a ed. São Paulo: Martins Fontes, 1997.

FLICK, Uwe. Introdução à pesquisa qualitativa. 3a ed. Porto Alegre: Artmed, 2009.

HELLER, Steven; TALARICO, Lita. Escola de design: projetos desafiadores de escolas do mundo todo. São Paulo: Editora Senac, 2016.

HIRATA, Helena. Da polarização das qualificações ao modelo da competência. In: Ferretti, C.J. et al. (Org.). Novas tecnologias, trabalho e educação: um debate multidisciplinar. Petrópolis: Vozes, 1994.

HOMEM DE MELO, Chico. Os desafios do designer e outros textos sobre design gráfico. São Paulo: Rosari, 2003.

LAWSON, Brien; DORST, Kees. Design Expertise. Burlington: Architectural Press, 2009. 
LIDELL, Willian; HOLDEN, Kristina; BUTLER, Jill. Princípios universais do design: 125 maneiras de aprimorar a usabilidade, influenciar a percepção, aumentar o apelo e ensinar por meio do design. Porto Alegre: Bookman, 2010.

LUPTON, Ellen; PHILLIPS, Jennifer Cole. Novos fundamentos do design. 2a ed. São Paulo: Cosac Naif, 2008.

MEGGS, Phillip B.; PURVIS, Alston W. História do Design Gráfico. São Paulo: Cosac Naify, 2009.

MONZEGLIO, Élide. A comunicação visual como tecnologia educacional: uma proposição didática de projeto. Sinopses, São Paulo, n. 5. p. 5-64, 1984.

MUNARI, Bruno. Design e comunicação visual: contribuição para uma metodologia didática. São Paulo: Martins Fontes, 2001.

NÓVOA, Antônio. Para uma análise das instituições escolares. In: NÓVOA, Antônio. (Org.). As organizações escolares em análise. 3a ed. Lisboa: Dom Quixote, 1999.

OLIVEIRA, Maria Rita Neto Sales. Formação e profissionalização dos professores do ensino técnico. In: ARANHA, Antônia V. et Al. (Org.). Diálogos sobre o trabalho: perspectivas multidisciplinares, Campinas: Papirus, 2005.

PERRENOUD, Philippe. Construir as competências desde a escola. Porto Alegre: Artmed, 1999.

PETEROSSI, Helena Gemignani. Formação do professor para o ensino técnico. São Paulo: Loyola, 1994.

QUELUZ, Maria Lopez Pinheiro (Org.). Questões pontuais sobre design e identidade. Design \& Identidade, Curitiba, v. 2, p. 13-32, 2008.

SCHÖN, Donald. A. Educando o profissional reflexivo: um novo design para o ensino e a aprendizagem. Porto Alegre: Artes Médicas Sul, 2000. 
TWYMAN, Michael. A schema for the study of graphic language. In: KOLERS, P.; WROLSTAD, M. \& BOUMA, H. (Eds.). Processing of visible language. New York: Plenum Press, v. 1, p. 117-150, 1979.

WICK, Rainer. Pedagogia da Bauhaus. São Paulo: Martins Fontes, 1989.

WILLIAMS, Rick; NEWTON, Julianne. Visual communication: integrating media, art, and science. New York: Routledge, 2007.

\subsection{4}

\section{Bibliografia complementar em suporte eletrônico}

GARIGLIO, José Ângelo; BURNIER, Suzana Lana. Os professores da educação profissional: saberes e práticas. Cadernos de pesquisa, v. 44, n. 154, p. 934-959, out./dez. 2014. Disponível em: <http://www.scielo.br/pdf/cp/v44n154/1980-5314-cp44-154-00934.pdf>. Acesso em: 20 maio 2016.

GOLDSMITH, Evelyn. Comprehensibility of illustration: an analytical model. Information Design Journal, v. 1, n. 3 p. 204-213, 1980. Disponível em: $<$ https://www.scribd.com/document/133830612/Evelyn-Goldsmith-Comprehensibilityof-lllustration> Acesso em: 3 set. 2018.

KRAMER, Sonia. Propostas pedagógicas ou curriculares: subsídios para uma leitura crítica. Educação \& Sociedade, v. 18, n. 60, p. 15-35. dez. 1997. Disponível em: $<$ http://www.scielo.br/scielo.php?pid=S0101-73301997000300002\&script=sci abstract\&tIng=pt $\gg$. Acesso em: 21 maio 2016.

OLIVEIRA Lúcia Helena M.; GATTI JR, Décio. História das instituições educativas: um novo olhar historiográfico. Cadernos de história da educação, v. 1, n. 1, p. 73-16, jan./dez. 2002. Disponível em: <http://www.seer.ufu.br/index.php/che/ article/view/310/302>. Acesso em: 20 maio 2016. 


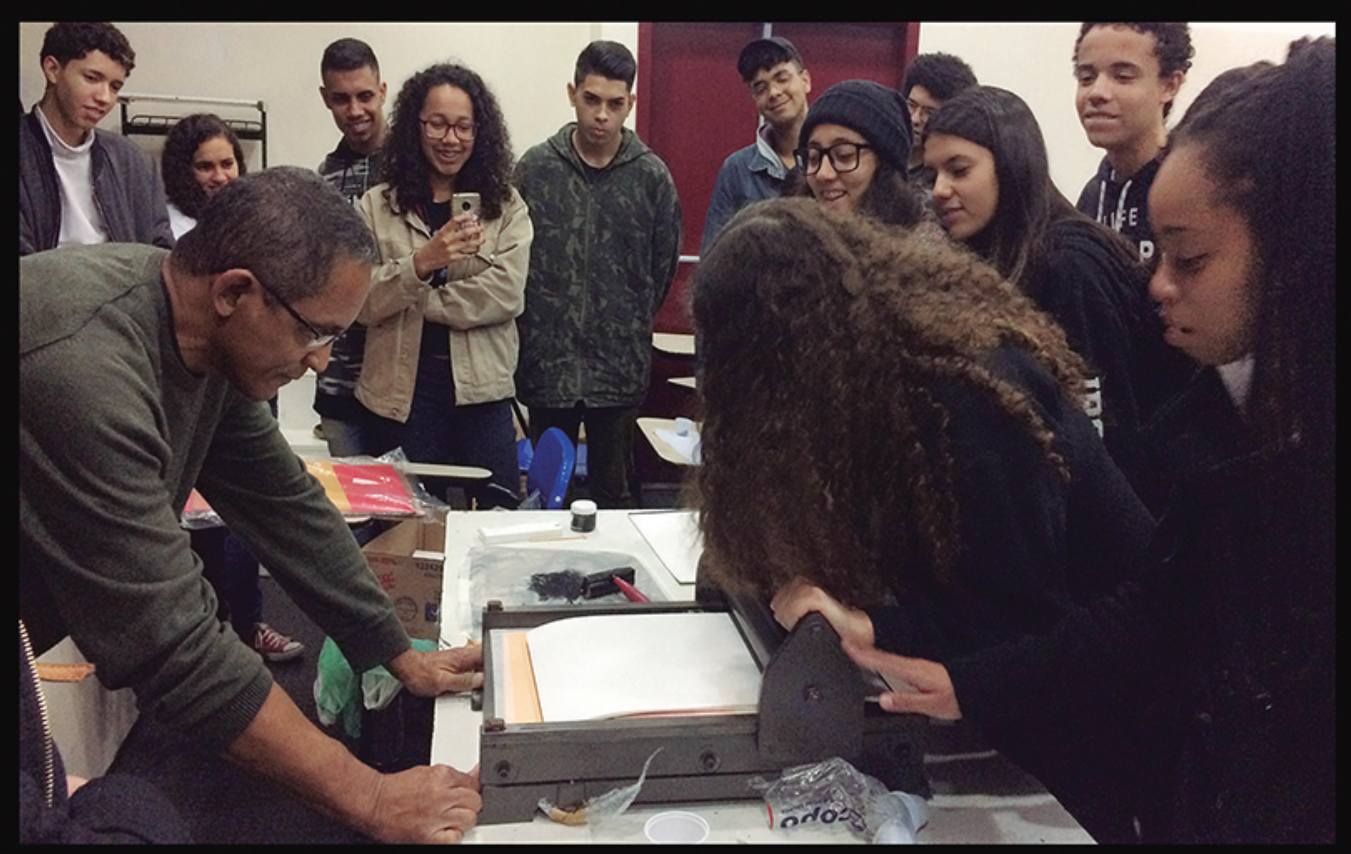

